VILNIAUS GEDIMINO TECHNIKOS UNIVERSITETAS

Žilvinas JUCHNEVIČIUS

\title{
CIKLIŠKAI LENKIAMŲ SRIEGINIŲ JUNGČIŲ DEFORMAVIMAS IR STIPRUMAS
}

DAKTARO DISERTACIJA

TECHNOLOGIJOS MOKSLAI, MECHANIKOS INŽINERIJA (09T) 
Disertacija rengta 2007-2011 metais Vilniaus Gedimino technikos universitete.

\section{Mokslinis vadovas}

doc. dr. Algimantas KRENEVIČIUS (Vilniaus Gedimino technikos universitetas, technologijos mokslai, mechanikos inžinerija -09T).

VGTU leidyklos TECHNIKA 1969-M mokslo literatūros knyga http://leidykla.vgtu.lt

ISBN 978-609-457-053-7

(C) VGTU leidykla TECHNIKA, 2011

(C) Žilvinas, Juchnevičius, 2011 Zilvinas.Juchnevicius@vgtu.lt 
VILNIUS GEDIMINAS TECHNICAL UNIVERSITY

Žilvinas JUCHNEVIČIUS

\section{DEFORMATION AND STRENGTH OF A CYCLICALLY BENT THREADED CONNECTION}

DOCTORAL DISSERTATION

TECHNOLOGICAL SCIENCES,

MECHANICAL ENGINEERING (09T)

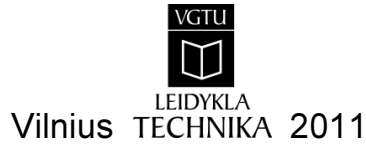


Doctoral dissertation was prepared at Vilnius Gediminas Technical University in 2007-2011.

\section{Scientific Supervisor}

Assoc Prof Dr Algimantas KRENEVIČIUS (Vilnius Gediminas Technical University, Technological Sciences, Mechanical Engineering - 09T). 


\section{Reziumè}

Disertacijoje, taikant apkrovų pasiskirstymo sriegio vijose modeliavima, nagrinėjamos lenkiamų srieginių jungčių mažaciklio stiprumo problemos. Modernesnès daugiaciklio ir mažaciklio ilgaamžiškumo skaičiavimo metodikos detaliai kiekybiškai ịvertina ašinès apkrovos pasiskirstymą vijose, kuris leidžia tiksliau ivertinti konstrukcijos ypatumu itaką. Disertacijoje siekiama ir cikliškai lenkiamoms srieginems jungtims sukurti apkrovos pasiskirstymo sriegyje skaičiavimo metodą ir pritaikyti ji ciklinio stiprumo skaičiavimui.

Sudaryta lenkiamos srieginès jungties elementų poslinkių darnos lygtis igalino sukurti trijų ruožų ir daugiaruožį lenkimo apkrovos pasiskirstymo jungtyje modelius ir įdiegti juos i norminio mažaciklio ilgaamžiškumo skaičiavimo grandinę.

Pirmame skyriuje pateikta literatūros šaltinių analizè. Jame apžvelgiama sunkiai apkrautų srieginių jungčių taikymo sritis ir apkrovimo sąlygos, apžvelgiami ir analizuojami atlikti tyrimai, susiję su srieginių jungčių cikliniu stiprumu.

Antrame skyriuje pateikti sriegio vijų poros deformavimo savybiu eksperimentinio tyrimo rezultatai ir anksčiau literatūroje neminètų nukraunamos ir pakartotinai apkraunamos vijų poros savybių analizè.

Trečiame skyriuje pateikta srieginès jungties elementų deformavimo schema, poslinkių darnos diferencialinès lygtys, diferencialinių lygčių analitiniai sprendiniai ir lenkiamos srieginès jungties modeliai - trijų ruožų ir daugiaruožis tamprieji modeliai lenkimo apkrovos pasiskirstymo skaičiavimui.

Ketvirtame skyriuje nustatyti smeigès lenkimo įrąžos, vijų apkrovos bei vietinių i̇tempių ciklo parametrai. Palyginus skaičiavimo ir eksperimentinių tyrimų rezultatus, patikrinta galimybė modifikuoto norminio mažaciklio ilgaamžiškumo skaičiavimo metodikoje taikyti lenkimo apkrovos pasiskirstymo sriegyje duomenis.

Penktame skyriuje pateikti du nauji srieginių jungčiu ciklinio ilgaamžiškumo padidinimo būdai ir jų matematiniai modeliai.

Disertacijos tema paskelbti 9 straipsniai: trys - žurnaluose, itrauktuose i Thomson ISI Web of Science sąrašą ir šeši - konferencijų pranešimų medžiagose. Disertacijos tema perskaityti 9 pranešimai Lietuvos ir užsienio šalių konferencijose ir seminaruose. 


\section{Abstract}

Applying simulations of loads distribution in threads, the disertation investigates the problems of low cycle strength of the threaded joints. More sophisticated high-cycle and low-cycle durability calculation methodologies already quantitatively assess the distribution of axial load among turns what enables a more accurate assessment of the influence of the constructional design particularities. This dissertation thesis aims to create a calculation methodology for the load distribution in the thread, intended for threaded connections cyclically bent too, and to apply this methodology for the calculation of cyclic strength. Created compatibility equation of the displacements of the elements of bent threaded connection enabled to construct the three-segmental and multi-segmental models of the distribution of bending load along turns and to introduce them in the range of the normative methodology for the fatigue calculation.

The dissertation consists of Introduction, 5 chapters, Conclusions, References and lists of published works and presentations in conferences of the author on the topic of dissertation. The introduction reveals the investigated problem, importance of the thesis and the object of research and describes the purpose and tasks of the paper, research methodology, scientific novelty, the practical significance of results examined in the paper and defended statements. The first chapter is dedicated to literature review. It covers the scope of heavily loaded threaded connections and load conditions, a review and analysis of research related to the cycle strength of threaded connections.In the second chapter is preseted the results of the experimental investigation of thread turn pair deformation and previous in the literature not mentioned an unloaded turn pair characteristic analysis. The third chapter presents the deformation scheme of the threaded connection elements, created displacements compatibility equation, differential equations analytical solutions and models for bent threaded connection - three segments and multi-segmental elastic models of bending load distribution calculations. In the fourth chapter the stud's cycle parameters is established: for the turns load and internal bending moment and for the turns local stress also. Using comparison with experimental results, it was checked the posibility to use data of the bending load distribution in thread for calculation methodology of lowcycle durability of the stud. The fifth chapter presents two methods and mathematical models to increase cycle durability of the threaded connections. There are published 9 articles of the theme of dissertation: three in journals, which are included in Thomson ISI Web of Science list and six of conference materials. The theme of dissertation was represented in 9 reports during lithuanian and foreign conferences and seminars. 


\section{Žymèjimai}

\section{Simboliai}

$P \quad$ - sriegio žingsnis;

$R \quad$ - sraigtinès linijos spindulys, atitinkantis sriegio vidurini skersmeni;

$R_{v} \quad-$ smeigès šerdies spindulys, atitinkantis sriegio įduba;

$L N \quad$ - neutralioji linija, einanti per centrą ir nustatyta vertinant tik lenkima;

C - koeficientas konvertuojantis sraigtinès linijos taško ilgio koordinatę i kampinę;

$H \quad$ - srieginès jungties ilgis (veržlès aukštis);

$i \quad$ - srieginès jungties ruožo eilès $\mathrm{Nr} .(i=1 ; 2 ; 3)$;

$H_{i} \quad$ - srieginès jungties ruožo ilgis;

$z \quad$ nagrinèjamo skerspjūvio, esančio nagrinèjamame ruože $i$, koordinatè $\left(z=z_{i}\right)$;

$z_{0} \quad$ - pradinio skerspjūvio ruože $i$ koordinate $\left(z_{0}=z_{0 i}\right)$;

$z_{H} \quad-$ galinio skerspjūvio ruože $i$ koordinate $\left(z_{H}=z_{H i}\right)$;

$z_{f} \quad-$ sinusoidès pradinès fazès ilgis;

$F_{t} \quad-$ išorinè ašinè îveržimo jèga;

$M_{f} \quad$ - išorinis lenkimo momentas;

$Q_{t}(z) \quad$ - vidinè ašinè ịveržimo jèga smeigès ir veržlès skerspjūvyje $z$;

$Q_{b}(z) \quad$ - vidinė ašinè lenkimo jèga smeigès ir veržlès skerspjūvyje $z$;

$Q(z) \quad$ - visa vidine ašinè jèga smeigès ir veržlès skerspjūvyje $z$;

$M(z) \quad$ - vidinis lenkimo momentas, smeigès ir veržlès skerspjūvyje $z$ dèl lenkimo poveikio;

$q_{t}(z) \quad-$ išskirstyta išilginė vijų poros apkrova ties koordinate $z$, dèl išorinès ašinès jègos poveikio;

$q_{b}(z) \quad$ - išskirstyta išilginè viju poros apkrova ties koordinate $z$, dèl išorinio lenkimo momento poveikio;

$q(z) \quad-$ visa vijų poros apkrova ties koordinate $z$;

$m(z) \quad$ - išskirstytas lenkimo momentas smeigès ir veržlès skerspjūvyje $z$;

$\delta_{t s}(z) \quad-$ smeigès vijos įlinkis ties koordinate $z$, dèl ašinès išorinès jejgos; 
$\delta_{t h}(z) \quad$ - veržlès vijos ịlinkis ties koordinate $z$, dèl ašinès išorinès jègos;

$\delta_{t}(z) \quad-$ vijos poros ịlinkis ties koordinate $z$, dèl ašinès išorinès jègos;

$\delta_{b s}(z) \quad$ - smeigès vijos ịlinkis ties koordinate $z$, dèl lenkimo;

$\delta_{b n}(z) \quad$ - veržlès vijos ịlinkis ties koordinate $z$, dèl lenkimo;

$\delta_{b}(z) \quad-$ vijos poros ilinkis ties koordinate $z$, dèl lenkimo;

$\varphi_{s}(z) \quad-$ smeigès skerspjūvio $z$ kampinis poslinkis;

$\varphi_{n}(z) \quad$ - veržlès skerspjūvio $z$ kampinis poslinkis;

$\chi(z) \quad$ ne visų profiliu sukibusių vijų poros paslankumas ties koordinate $z$;

$\gamma_{f} \quad-$ visų profiliu sukibusių vijų poros paslankumas;

$t_{f} \quad-$ visu profiliu sukibusiu viju sukibimo gylis;

$t_{p}(z) \quad-$ ne visų profiliu sukibusių vijų sukibimo gylis ties jungties koordinate $z$;

$E_{s} \quad$ - smeigès medžiagos tamprumo modulis;

$E_{n} \quad-$ veržlès medžiagos tamprumo modulis;

$I_{s}-$ smeigès šerdies inercijos momentas, apskaičiuotas pagal sriegio įdubos skersmeni;

$I_{n} \quad-$ veržlès skerspjūvio inercijos momentas, apskaičiuotas pagal sriegio įdubos skersmeni;

$\lambda \quad$ - lenkimo standumo koeficientas: $\lambda=1 /\left(E_{s} I_{s}\right)+1 /\left(E_{n} I_{n}\right)$;

$V \quad-$ pastovusis koeficientas ne visų profiliu sukibusių vijų paslankumo funkcijoje $\chi(z)$, nustatomas ruožams $i=1$ ir $i=3$;

$U$ - laipsnio rodiklis ne visų profiliu sukibusių vijų paslankumo funkcijoje $\chi(z)$, nustatomas ruožams $i=1$ ir $i=3$;

$y(z) \quad-$ vijų poros ịlinkio amplitudès funkcija;

A - diferencialinès lygties lenkimui sprendinio pastovieji koeficientai, nustatomi

$B \quad$ ruožams $i=1,2,3$;

$B \quad-$ pastovusis koeficientas ruožo $i=2$ viju ilinkių diferencialinėje lygtyje;

$N \quad$ - pastovusis koeficientas ruožo $i=2$ vijų įlinkių diferencialinès lygties sprendinyje;

$f_{f A}(z) \quad$ - kintamų daugiklių prie koeficientu $A$ ir $B$ žymenys diferencialinès lygties

$f_{f B}(z) \quad$ sprendinio išraiškoje, kai $i=2$;

$F_{f A}(z) \quad$ - kintamų daugiklių prie koeficientu $A$ ir $B$ žymenys vidinio lenkimo momento

$F_{f B}(z) \quad$ išraiškoje, kai $i=2$;

$f_{p A}(z) \quad$ kintamų daugiklių prie koeficientu $A$ ir $B$ žymenys diferencialinès lygties

$f_{p B}(z) \quad$ sprendinio išraiškoje, kai $i=1$ ir $i=3$;

$F_{p A}(z) \quad$ - kintamų daugiklių prie koeficientų $A$ ir $B$ žymenys lenkimo momento išraiš-

$F_{p B}(z) \quad$ koje, kai $i=1$ ir $i=3$;

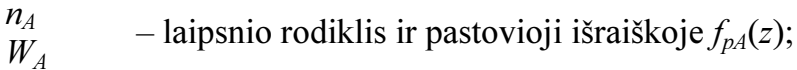

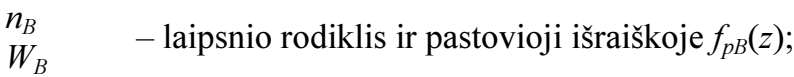

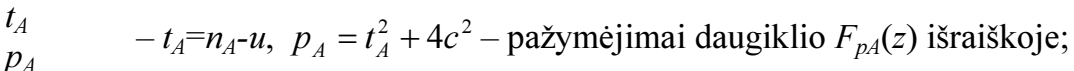

$t_{B} \quad-t_{B}=n_{B}-u ; p_{B}=t_{B}^{2}+4 c^{2}-$ pažymèjimai daugiklio $F_{p B}(z)$ išraiškoje. 
Simboliai ir pažymèjimai ašine jèga veikiamos jungties lygtyse

$A_{t} \quad$ - pastovieji koeficientai, ašinės irąžos ir vijų apkrovos skaičiavimo išraiškose, $B_{t} \quad$ kai jungtị veikia ašinè îveržimo jèga (ruožams $i=1,2,3$ );

$f_{t f A}(z) \quad$ - kintamų daugiklių prie koeficientų $A_{t}$ ir $B_{t}$ žymenys tempiamos jungties vijų $f_{t f B}(z) \quad$ apkrovos išraiškoje, kai $i=2$;

$F_{t f A}(z) \quad$ - kintamų daugiklių prie koeficientų $A_{t}$ ir $B_{t}$ žymenys vidinès ašinès jègos iš$F_{t f B}(z) \quad$ raiškoje, kai $i=2$;

$f_{t p A}(z) \quad$ - kintamų daugiklių prie koeficientų $A_{t}$ ir $B_{t}$ žymenys tempiamos jungties vijų $f_{t p B}(z) \quad$ apkrovos išraiškoje, kai $i=1$ ir $i=3$;

$F_{t p A}(z) \quad$ - kintamų daugiklių prie koeficientu $A_{t}$ ir $B_{t}$ žymenys vidinès ašinės jègos iš$F_{t p B}(z) \quad$ raiškoje, kai $i=1$ ir $i=3$;

$A_{s} \quad$ - smeigès skerspjūvio plotas, apskaičiuotas pagal sriegio i̇dubos skersmeni;

$A_{n} \quad$ - veržlès skerspjūvio plotas, apskaičiuotas pagal sriegio įdubos skersmeni;

$\beta \quad$ - tempimo standumo koeficientas: $\beta=1 /\left(E_{s} A_{s}\right)+1 /\left(E_{n} A_{n}\right)$;

$m_{t} \quad-m_{t}=\left(\beta / \gamma_{f}\right)^{0,5}$;

$C_{t} \quad$ - pastovieji koeficientai, tempiamos jungties vijų paslankumo išraiškoje, kai

$n_{t} \quad i=1$ ir $i=3$;

$R_{s r} \quad-$ sriegio įdubos spindulys;

$F \quad$ - vijos kontakto paviršiaus projekcija i statmeną smeigès ašiai plokštuma;

$p(z) \quad$ - slègis sukibusių vijų kontakto plote;

$K_{t, m} \quad$ - i̇tempių koncentracijų koeficientas, ivertinantis vijos apkrovos $q_{t}$ poveiki;

$K_{t, 0} \quad$ - itempių koncentracijų koeficientas, įvertinantis smeigès šerdies nominalių ašinių itempių poveiki;

$K_{b, m} \quad$ - itempiu koncentracijų koeficientas, ivvertinantis vijos apkrovos $q_{b}$ poveikį;

$K_{b, 0} \quad$ - įtempių koncentracijų koeficientas, įvertinantis smeigès šerdies lenkimo nominaliu itempiu poveiki;

$K_{r} \quad$ - vietiniu itempių sumažejimą (dèl lenkimo) ịvertinantis koeficientas;

$\sigma_{t}^{*}(z) \quad$ - smeigès sriegio sąlyginiai vietiniai tamprieji ịtempiai dèl ašinès jègos;

$\sigma_{t, n o m} \quad-$ nominalūs ašiniai įtempiai smeigès šerdyje;

$\sigma_{b}^{*}(z) \quad$-smeigès sriegio sąlyginiai vietiniai tamprieji ịtempiai dèl lenkimo ;

$\sigma_{b, \text { nom }} \quad$ nominalūs lenkimo įtempiai smeigès šerdyje;

$\sigma^{*}(z) \quad-$ visas smeigès sriegio sąlyginis vietinis tamprusis itempis. 



\section{Turinys}

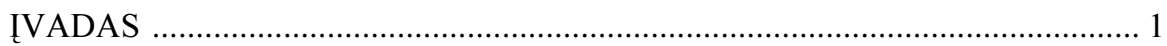

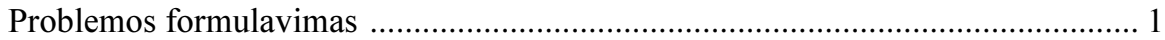

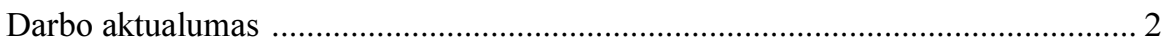

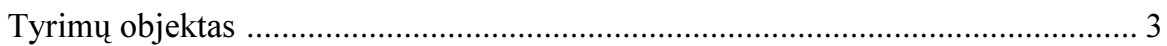

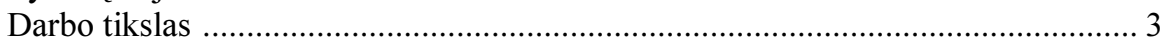

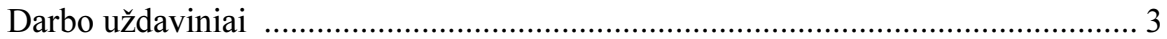

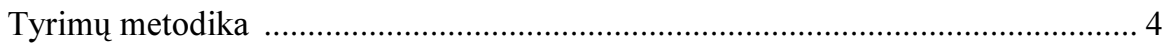

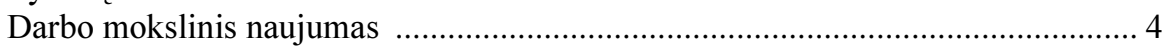

Darbo rezultatų praktinė reikšmė ………........................................................ 4

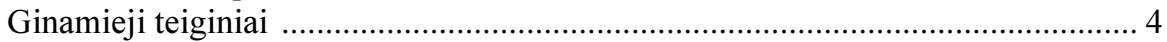

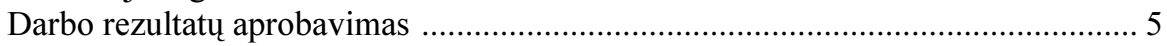

Disertacijos struktūra ............................................................................ 5

1. SRIEGINIŲ JUNGČIŲ CIKLINIS STIPRUMAS IR DEFORMAVIMAS ............ 7

1.1. Srieginių jungčių lenkimas inžinerinèse konstrukcijose ................................. 7

1.2. Apkrovos pasiskirstymas sriegyje ……………..................................... 10

1.3. Itempių koncentracija sriegio vijų pašaknyje .............................................. 15

1.4. Srieginių jungčių ciklinis ilgaamžiškumas .................................................. 19

1.5. Ciklinio ilgaamžiškumo padidinimas ........................................................ 23

1.6. Pirmojo skyriaus išvados ir disertacijos uždavinių formulavimas ................. 24 
2. VIJU POROS DEFORMAVIMO SAVYBIUQ EKSPERIMENTINIS TYRIMAS 27

2.1. Vijų poros tempimo bandymo metodas ...................................................... 27

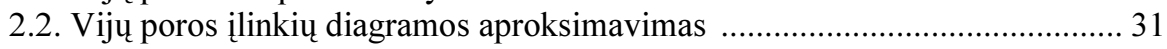

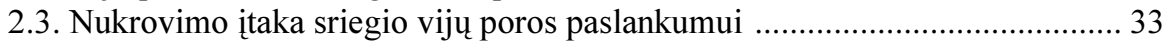

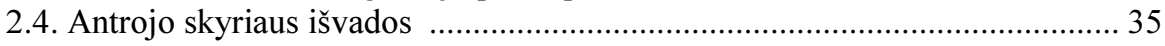

3. LENKIAMŲ SRIEGINIŲ JUNGČIŲ TAMPRIEJI MODELIAI ......................... 37

3.1. Lenkiamos srieginès jungties trijų ruožų modelis ..................................... 38

3.1.1. Srieginès jungties deformavimo sritis ...................................... 38

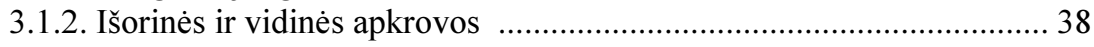

3.1.3. Srieginès jungties diskretizavimas ................................................ 40

3.1.4. Lenkiamos jungties sriegio vijų ilinkiai ..................................... 42

3.1.5. Srieginès jungties elementų poslinkių darna ................................. 46

3.1.6. Vijų ilinkių diferencialinès lygtys .............................................. 49

3.1.7. Trijų ruožų srieginès jungties kraštinès sąlygos .............................. 49

3.2. Diferencialinių lygčių sprendiniai ............................................................... 50

3.2.1. Pastovaus standumo vijų ruožo diferencialinès lygties sprendinys .... 50

3.2.2. Kintamo standumo vijų ruožo diferencialinès lygties sprendinys ...... 52

3.2.3. Analitinio sprendinio lygčiu visuma ............................................... 54

3.2.4. Lenkiamos jungties trijų ruožų kraštinès sąlygos ............................ 55

3.2.5. Analitinių ir skaitinių sprendinių palyginimas ................................. 56

3.2.6. Ašinès įažos ir vijų apkrovos ..................................................... 57

3.3. Irąžuc, vijų apkrovų ir vietinių įtempių pasiskirstymas

necentriškai tempiamose srieginèse jungtyse .........................................6 60

3.3.1. Irąžų ir vijų apkrovų pasiskirstymas ..............................................6 60

3.3.2. Vietinių itempių pasiskirstymas smeigès sriegyje ......................... 63

3.3.3. Vietiniu įtempiu palyginimas su eksperimento duomenimis ............ 66

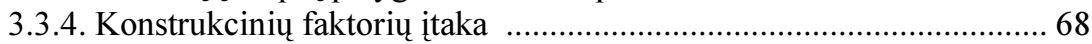

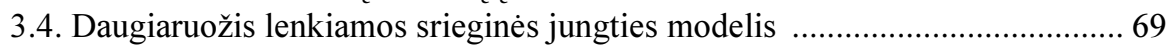

3.4.1. Po įveržimo lenkiamos srieginès jungties diskretizavimas ............... 70

3.4.2. Pusvijų nukrovimo itaka apkrovos pasiskirstymui ......................... 71

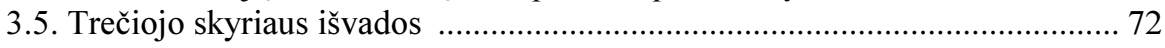

4. CIKLIŠKAI LENKIAMŲ SRIEGINIŲ JUNGČIŲ ILGAAMŽIŠKUMAS ........ 75

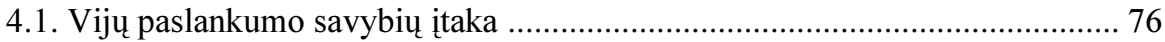

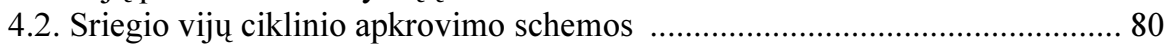

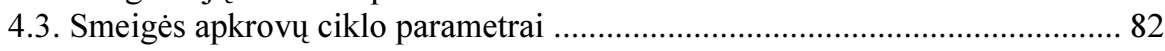

4.4. Smeigès vietinių itempių ciklo parametrai .............................................. 83

4.5. Modifikuoto norminio mažaciklio ilgaamžiškumo skaičiavimo taikymas lenkiamoms srieginėms jungtims ...................................................... 85

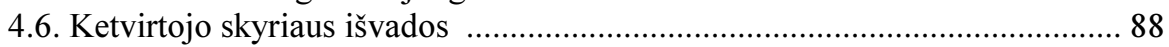

5. SRIEGINIŲ JUNGČIU CIKLINIO ILGAAMŽIŠKUMO PADIDINIMAS......... 89

5.1. Lenkiamos srieginès jungties pozicionavimo metodas ................................. 90

5.1.1. Ciklinio ilgaamžiškumo padidinimo modelis ................................. 90

5.1.2. Skaičiavimo rezultatai .................................................................. 93 
5.2. Srieginès jungties išankstinio perkrovimo metodas........................................ 94

5.2.1. Tampraus išankstinio perkrovimo modelis ...................................... 95

5.2.2. Plastiško išankstinio perkrovimo modelis ......................................... 98

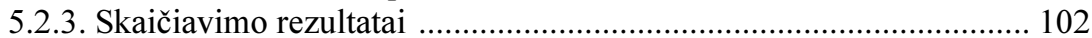

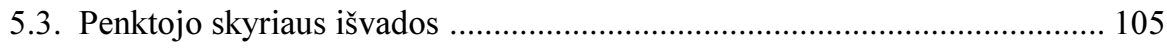

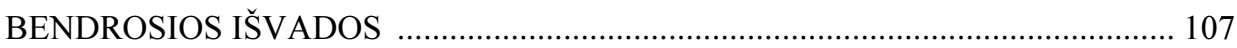

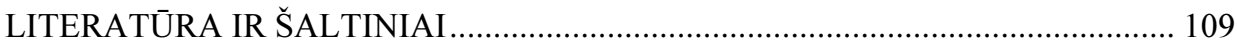

AUTORIAUS PUBLIKACIJŲ DISERTACIJOS TEMA SĄRAŠAS ....................... 115

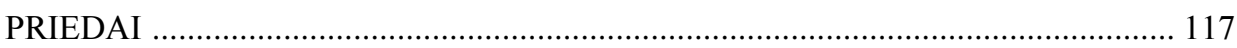

A priedas. Viju poros tempimo bandymo rezultatai ........................................ 117

B priedas. Ivijų paslankumo funkcijos koeficientai ............................................ 118

C priedas. Lenkimo momento funkcijų sankirtos ............................................... 121 



\section{Contents}

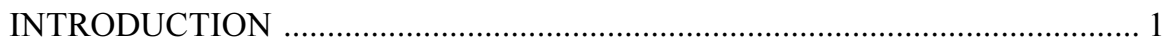

Formulation of the problem ………………………..................................... 1

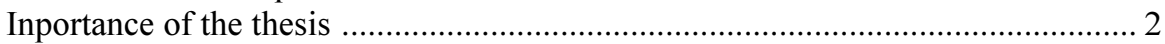

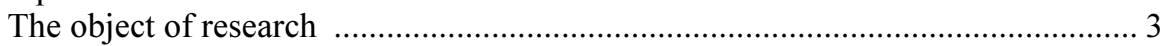

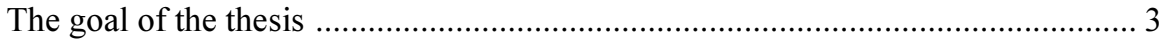

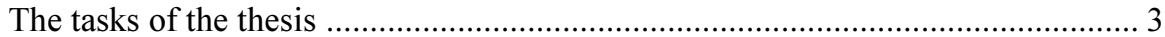

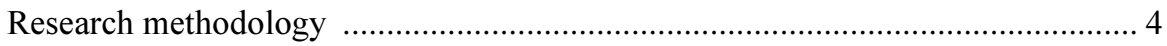

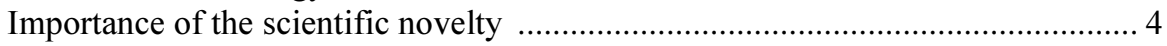

Practical significance of achieved results ......................................................... 4

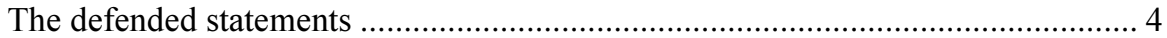

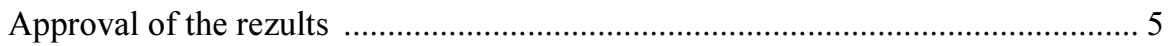

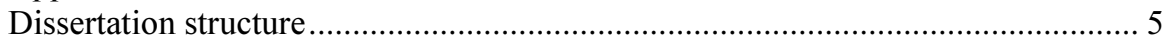

1. CYCLIC STRENGTH AND DEFORMATION OF THE THREADED

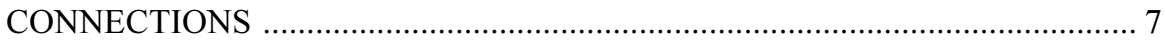

1.1. Bent threaded connections in engineering structures ..................................... .

1.2. The loads distribution along thread ....................................................... 10

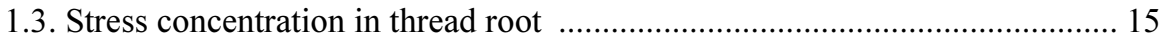

1.4. Cyclic lifetime of the threaded connections ............................................... 19

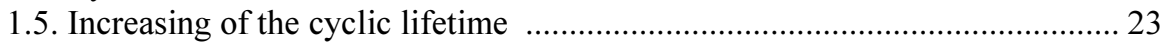

1.6. Conclusions of the first chapter and formulation of dissertation task............. 24 
2. EXPERIMENTAL INVESTIGATION OF THE TURN PAIR

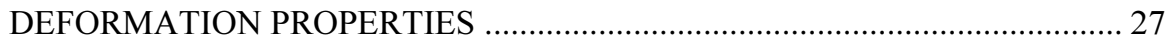

2.1. Turn pair tension test's method ............................................................... 27

2.2. Approximation of the diagram of the turn pair deflection ............................. 31

2.3. Unloading influence to pliability of the turn pair ........................................ 33

2.4. Conclusions of the second chapter ............................................................. 35

3. ELASTIC MODELS FOR THE BENT THREADED CONNECTIONS ............. 37

3.1. The model of bent threaded connection in three segments ............................ 38

3.1.1. Deformation range of the threaded connection ................................... 38

3.1.2. External and internal loads .............................................................. 38

3.1.3. Discredit of the threaded connection ................................................. 40

3.1.4. Deflections of the turns in bent threaded connection .......................... 42

3.1.5. Compatibility of the displacements of the connection elements ........ 46

3.1.6. Differential equations for the turns deflections .................................. 49

3.1.7. Boundary conditions of the three-segmental connection .................... 49

3.2. Solutions of the differential equations ...................................................... 50

3.2.1. Solutions for the segment of constant turn's pliability ......................... 50

3.2.2. Solutions for the segment of variable turn's pliability ........................ 52

3.2.3. Completeness of the equations of the analytical solution .................... 54

3.2.4. Boundary conditions of the bent thee-segmental connection .............. 55

3.2.5. Comparison of the analytical and numerical solutions ........................ 56

3.2.6. Axial forces and turn loads ............................................................ 57

3.3. Distributions of internal forces, turn loads and local stresses at eccentric

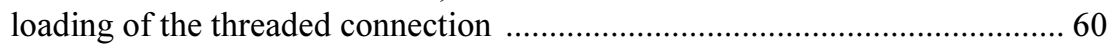

3.3.1. Distributions of internal forces and turn loads .......................................... 60

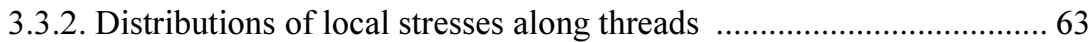

3.3.3. Comparison of the local stresses with the experimental data ............. 66

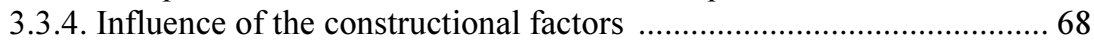

3.4. Multi-segmental model of bent threaded connection ....................................... 69

3.4.1. Discredit of the threaded connection bent after tightening .................. 70

3.4.2. Influence of the semi-turns unloading ............................................... 71

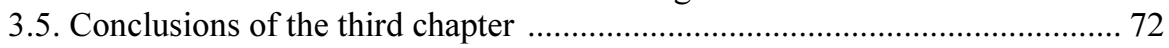

4. DURABILITY OF THE CYCLICALLY BENT THREADED

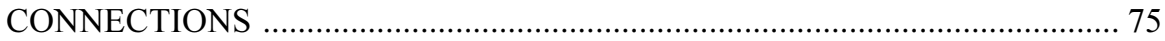

4.1. Influence of the turn pliabilities .............................................................. 76

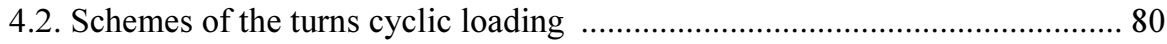

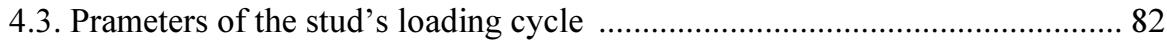

4.4. Prameters of the stud's local stresses cycle ................................................... 83

4.5. Applying of the modified normative of low cycle durability

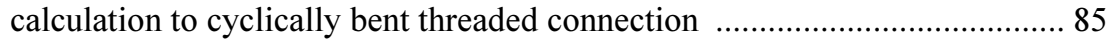

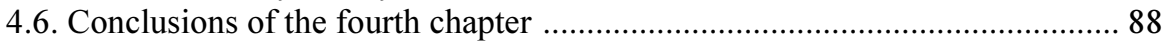


5. INCREASING OF THE CYCLIC DURABILITY OF THE THREADED

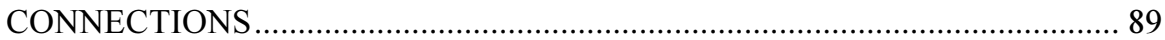

5.1. Positioning method for bent threaded connection ......................................... 90

5.1.1. The model of increasing of cyclic durability ..................................... 90

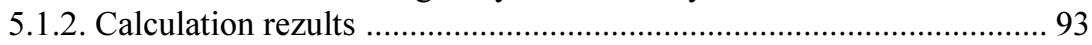

5.2. Method of pre-overloading of the threaded connection.................................. 94

5.2.1. Model of the elastic pre-overloading ................................................... 95

5.2.2. Model of the plastic pre-overloading ………....................................... 98

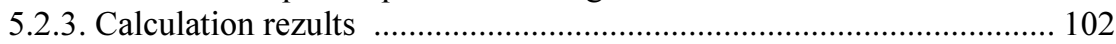

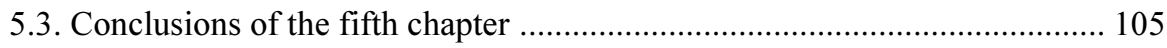

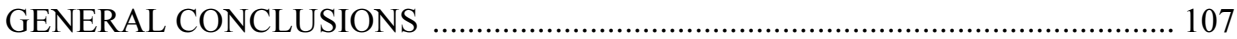

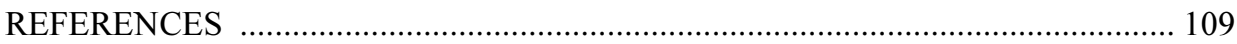

LIST OF PUBLISHED WORKS ON THE TOPIC OF THE DISSERTATION ........ 115

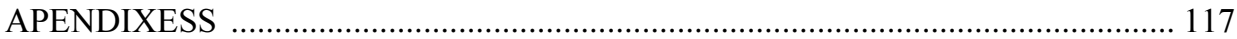

A appendix. Results of tests of the single turn pair tension ................................ 117

$\mathrm{B}$ appendix. Coefficients of the runout's pliability function ................................ 118

$\mathrm{C}$ appendix. Intersections of the bending moment functions............................... 121 



\section{Ivadas}

\section{Problemos formulavimas}

Ivairių gabaritų srieginès jungtys plačiai naudojamos mašinų gamybos, energetikos, transporto ir statybos pramonès inžinerinèse konstrukcijose, kurios dažnai patiria kintamas ciklines apkrovas dèl temperatūros, vidaus slègio ir jungiamų detalių deformacijų kitimo. Dažnai smeiges ir varžtus veikia ne vien tik ašinė apkrova, bet ir lenkimo momentai.

Srieginès jungtys dažnai patiria ciklinių lenkimo apkrovų dèl temperatūros, vidaus slègio ir jungiamų detalių deformacijų kitimo.

Srieginèms jungtims, kurios patiria ašinių ciklinių apkrovų, jau yra sukurtos modernesnès daugiaciklio ir mažaciklio ilgaamžiškumo skaičiavimo metodikos, kuriomis detaliai, kiekybiškai įvertinamas ašinès apkrovos tarp vijų pasiskirstymas. Apkrovos pasiskirstymo sriegyje kiekybiniai duomenys leidžia detaliau ir tiksliau įvertinti konstrukcijos ypatumų - jungties ilgio, medžiagos, veržlès ir vijų formos bei jungties elementų deformavimo stadijų - itaką.

Tokios ilgaamžiškumo skaičiavimo metodikos cikliškai lenkiamoms srieginėms jungtims netaikomos, nes nèra lenkiamoms srieginėms jungtims sukurtų apkrovos pasiskirstymo vijose analitinių modelių, kuriuos tiktų taikyti praktikoje. Nèra šioje srityje sukurta ir modelių, kurie skaičiuojami baigtinių elementų metodu. 
Kadangi sriegine jungtis yra kompleksinis mazgas, sudarytas iš deformuojamų elementų tai apkrovos pasiskirstymą tarp vijų lemia jungties elementų deformacijų ir poslinkių suderinamumas. Matematiškai jungties deformuotam būviui aprašyti reikalingi teoriniai ir eksperimentiniai duomenys, atspindintys jungties elementų deformavimo specifinius ypatumus, pasireiškiančius veikiant lenkimui.

Disertacijoje siekiama sukurti cikliškai lenkiamų srieginių jungčių apkrovos pasiskirstymo sriegyje skaičiavimo metodą ir pritaikyti ji mažacikliam ilgaamžiškumui skaičiuoti.

\section{Darbo aktualumas}

Srieginès jungtys dažnai patiria ciklines lenkimo apkrovas dèl temperatūros, vidaus slègio ir jungiamų detalių deformacijų kitimo.

Srieginèms jungtims, kurios patiria ašines ciklines apkrovas jau yra sukurtos modernesnès daugiaciklio ir mažaciklio ilgaamžiškumo skaičiavimo metodikos, kuriose detaliai kiekybiškai yra įvertinamas ašinės apkrovos pasiskirstymas tarp vijų. Apkrovos pasiskirstymo sriegyje kiekybiniai duomenys leidžia detaliau ir tiksliau įvertinti konstrukcijos ypatumų (jungties ilgio, medžiagos, veržlès ir vijų formos) ir jungties elementų deformavimo stadijų itaką.

Tokios ilgaamžiškumo skaičiavimo metodikos cikliškai lenkiamoms srieginèms jungtims netaikomos, kadangi lenkiamoms srieginèms jungtims nèra sukurtų apkrovos pasiskirstymo vijose analitinių modelių, tinkamų praktiniam naudojimui. Šioje srityje taip pat nèra sukurtų ir modelių, kurie skaičiuojami baigtinių elementų metodu.

Kadangi sriegine jungtis yra kompleksinis mazgas, kuri sudaro deformuojami elementai, tai apkrovos pasiskirstymą tarp vijų lemia jungties elementų deformacijų ir poslinkių suderinamumas. Matematiškai aprašant jungties deformuotą būvî, reikalingi teoriniai ir eksperimentiniai duomenys, kurie atspindètų jungties elementų deformavimo specifinius ypatumus, pasireiškiančius veikiant lenkimui.

Disertacijoje siekiama cikliškai lenkiamoms srieginėms jungtims sukurti apkrovos pasiskirstymo sriegyje skaičiavimo metodą ir pritaikyti ji ciklinio stiprumo skaičiavimui. 


\section{Tyrimų objektas}

Cikliškai lenkiamos srieginès jungtys.

\section{Darbo tikslas}

Lenkimo apkrovos pasiskirstymo sriegio vijose nustatymui sukurti cikliškai lenkiamos srieginès jungties modelius ir pritaikyti juos norminiam ciklinio ilgaamžiškumo skaičiavimui.

\section{Darbo uždaviniai}

Darbo tikslui pasiekti reikia spręsti šiuos uždavinius:

1. Eksperimentiškai nustatyti nukraunamų ir pakartotinai apkraunamų sriegio vijų porų paslankumo rodiklius.

2. Sudaryti lenkiamos srieginès jungties elementų tampraus deformavimo schemą ir vijų ịlinkių, veržlès ir smeigès skerspjūvių kampinių poslinkių suderinamumą aprašančias diferencialines lygtis: a) kai sriegio vijos yra sukibusios visu profiliu, b) kai sriegio vijos yra sukibusios ne visu profiliu. Nustatyti diferencialinių lygčių apytikslius analitinius sprendinius ir patikrinti juos skaitiniais metodais.

3. Taikant diferencialinių lygčių analitinius sprendinius, sudaryti lenkimo apkrovos pasiskirstymo sriegio vijose modelius: a) trijų ruožų modeli necentriškai tempiamos jungties atvejui, b) daugiaruoži modeli atvejui, kai srieginè jungtis lenkiama po įveržimo.

4. Pritaikyti sudarytus apkrovos pasiskirstymo sriegio vijose modelius lenkiamų srieginių jungčių ciklinio ilgaamžiškumo (iki plyšio atsiradimo) norminiam skaičiavimui ir patikrinti skaičiavimo rezultatus remiantis eksperimentiniais duomenimis.

5. Pasiūlyti būdus srieginès jungties ilgaamžiškumo padidinimui ir vietinių itempių sumažinimui pavojingoje srieginès jungties srityje. Sudaryti jų matematinius modelius. 


\section{Tyrimų metodika}

Darbe taikomi analiziniai, skaitiniai ir eksperimentiniai tyrimų metodai.

\section{Darbo mokslinis naujumas}

Rengiant disertaciją buvo gauti šie mechanikos inžinerijos mokslui nauji rezultatai:

1. Lenkiamos srieginès jungties deformavimo apibūdinimui pasiūlyta originali deformavimo schema ir sudarytos vijų illinkius su veržlès ir smeigès skerspjūvių kampiniais poslinkiais siejančios poslinkių suderinamumo diferencialinès lygtys: a) kai sriegio vijos yra sukibusios visu profiliu; b) kai sriegio vijos yra sukibusios ne visu profiliu.

2. Sudaryti lenkimo apkrovos pasiskirstymo sriegineje jungtyje modeliai: a) trijų ruožų necentriškai tempiamos srieginès jungties modelis, b) daugiaruožis po įveržimo lenkiamos srieginès jungties modelis.

3. Eksperimentiškai nustatyti pakartotinai apkraunamų sriegio vijų porų paslankumo rodikliai.

4. Sukurtas ciklinio ilgaamžiškumo padidinimo metodas, kuris igyvendinamas periodiškai keičiant srieginès jungties padètị lenkimo plokštumos atžvilgiu. Sukurtas išankstinio perkrovimo metodas vietinių itempių sumažinimui smeigès sriegyje. Abiems metodams sudaryti matematiniai modeliai.

\section{Darbo rezultatų praktinè reikšmè}

Darbo rezultatai igalina tiksliau įvertinti lenkimo apkrovos poveikị ir konstrukcinių veiksnių itaką apkrovų pasiskirstymui sriegio vijose bei tiksliau prognozuoti lenkiamų srieginių jungčių ciklini ilgaamžiškumą. Jungties ir lenkimo plokštumos tarpusavio padèties periodinio keitimo metodas leidžia padidinti cikliškai lenkiamos srieginès jungties ilgaamžiškumą.

\section{Ginamieji teiginiai}

1. Ženklus sriegio vijų poros paslankumo pokytis pasireiškia po pirmojo apkrovimo ją nukraunant ir pakartotinai apkraunant. 
2. Sudaryti trijų ruožų ir daugiaruožis lenkiamos srieginès jungties modeliai ịvertina vijų sukibties nevientisumą ir vijų apkrovimo pobūdi - apkrovimą arba nukrovimą - necentriškai tempiamų ir po i̇veržimo lenkiamų jungčių atvejais. Modelių taikymas patikslina cikliškai lenkiamų srieginių jungčių ilgaamžiškumo skaičiavimą.

3. Periodiški jungties padeties keitimai lenkimo plokštumos atžvilgiu padidina cikliškai lenkiamos srieginès jungties ilgaamžiškumą. Išankstinis jungties perkrovimas sumažiną smeigès sriegio vietinius ittempius pavojingoje jungties srityje.

\section{Darbo rezultatų aprobavimas}

Disertacijos tema yra atspausdinti 9 moksliniai straipsniai: trys - mokslo žurnaluose, itrauktuose i Thomson ISI sąrašą (Krenevičius 2009a, Krenevičius 2010a, Juchnevičius 2011a); šeši - recenzuojamoje tarptautinès konferencijos medžiagoje (Krenevičius 2008, Juchnevičius 2009b, Juchnevičius 2010b, Juchnevičius 2011 b, Juchnevičius 2011c, Krenevičius 2011d).

Disertacijoje atliktų tyrimų rezultatai buvo paskelbti šiose mokslinėse konferencijose Lietuvoje ir užsienyje:

- Tarptautineje konferencijoje „Mechanika“ 2008-2011 m. Kaune;

- Tarptautineje konferencijoje „Erin“ 2011 m. High Tatras, Slovakia.

\section{Disertacijos struktūra}

Disertaciją sudaro: ịvadas, penki skyriai, bendrosios išvados, literatūra ir šaltiniai, autoriaus publikacijų sąašas ir trys priedai. Disertacijos apimtis yra 122 puslapiai, joje pateikta 64 paveikslai ir 8 lentelès. Disertacijoje panaudoti 86 literatūros šaltiniai.

Pirmame skyriuje pateikta literatūros šaltinių analizè. Jame apžvelgiama sunkiai apkrautų srieginiu jungčių taikymo sritis ir apkrovimo sąlygos, apžvelgiami ir analizuojami atlikti tyrimai, susiję su srieginių jungčių cikliniu stiprumu.

Antrame skyriuje pateikti sriegio vijų poros deformavimo savybių eksperimentinio tyrimo rezultatai ir anksčiau literatūroje neminètų nukraunamos ir pakartotinai apkraunamos vijų poros savybių analizè.

Trečiame skyriuje pateikta srieginès jungties elementų deformavimo schema, poslinkių darnos diferencialinès lygtys, diferencialinių lygčių analitiniai 
sprendiniai ir lenkiamos srieginès jungties modeliai - trijų ruožų ir daugiaruožis tamprieji modeliai lenkimo apkrovos pasiskirstymo skaičiavimui.

Ketvirtame skyriuje nustatyti smeigès lenkimo įrąžos, vijų apkrovos bei vietinių įtempių ciklo parametrai. Palyginus skaičiavimo ir eksperimentinius rezultatus, patikrinta galimybė modifikuoto norminio mažaciklio ilgaamžiškumo skaičiavimo metodikoje taikyti lenkimo apkrovos pasiskirstymo sriegyje duomenis.

Penktame skyriuje pateikti du nauji srieginių jungčių ciklinio ilgaamžiškumo padidinimo būdai ir jų matematiniai modeliai. 


\section{1}

\section{Srieginių jungčių ciklinis stiprumas ir deformavimas}

Šiame skyriuje pateikta literatūros šaltinių apie srieginių jungčių apkrovimo sąlygas ir jų lenkimo atvejus, pasitaikančius inžinerinèse konstrukcijose, analizè. Analizuojami modeliai, skirti apkrovu pasiskirstymo sriegio vijose skaičiavimams, kai sriegines jungtis veikia ašinè ir lenkimo apkrovos. Pateikta analizė apie sriegio įtempių koncentracijos koeficientus, nustatomus eksperimentiniais ir teoriniais metodais. Apžvelgti srieginiu jungčių ciklinio ilgaamžiškumo skaičiavimo metodai ir jų taikymas, ivertinant lenkimo apkrovas. Nagrinejjami literatūroje pateikti eksperimentiniai jungčių nuovargio tyrimų rezultatai, nustatyti plyšio atsiradimo ir visiško suirimo stadijoms. Analizuoti darbai, kurie aprašo srieginių jungčių ciklinio ilgaamžiškumo padidinimo metodus.

\subsection{Srieginių jungčių lenkimas inžinerinèse konstrukcijose}

Atliekant atsakingų mazgų stiprumo skaičiavimus, svarbu teisingai įvertinti srieginių jungčių, veikiant statinèms ir ciklinèms apkrovoms, patikimumą. Sunkiai apkrautų irenginių eksploatavimo patirtis rodo, kad srieginių jungčių nuovarginį 
suirimą dažnai sukelia lenkimo apkrovos, kurių atsiradimas ne visada būna numatytas arba jo poveikis nepakankamai tiksliai ịvertintas. Dažnai flanšinėse ir tvirtinimo jungtyse smeigių arba varžtu lenkimas neišvengiamas dẻl konstrukcijos ypatumų arba dèl apkrovos krypties.

Atominių elektrinių irenginiuose prie sunkiai apkraunamų ir atsakingų, priskiriamos srieginès jungtys, naudojamos aukšto slègio induose sujungiamų elementu (pvz., dangčio ir korpuso) sandarumui užtikrinti (1.1 pav.), cirkuliacinių siurblių ir sklendžių tvirtinimui prie vamzdynų. Čia smeigių nominalūs įtempimai siekia arba viršija 380-450 MPa, o ciklu skaičius iki plyšio atsiradimo arba visiško suirimo yra mažaciklio irimo srityje - neviršija $5 \cdot 10^{4}-10^{5}$ ciklų (Махутов et al. 1987, RF normos 1989, ASME Code 1995). Smeigès patiria iki $10^{3}-5 \cdot 10^{3}$ ciklų apkrovos ciklų jas įveržiant, taip pat ịrengimų hidraulinio išbandymo, paleidimo, stabdymo, pilno ar dalinio ataušinimo, našumo ir galingumo pakeitimo, perkrovos, avariniais ir remonto atvejais.

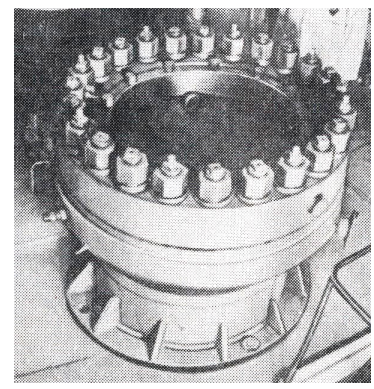

a

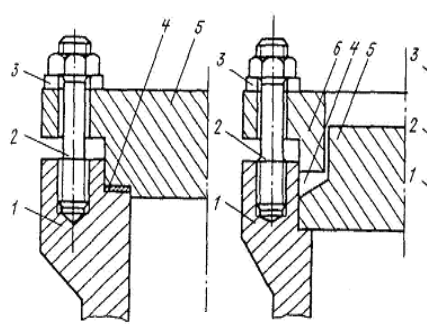

$\mathrm{b}$

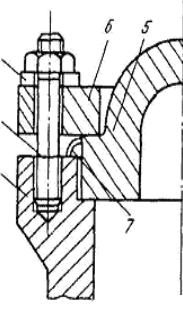

d

1.1 pav. Slègio indo flanšinè jungtis (a), indo dangčio tvirtinimo konstrukcijos (b, c, d)

Fig. 1.1. Threaded connection in flange of vessel (a), fasteners of closure (b, c, d)

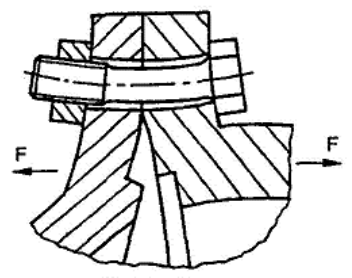

a

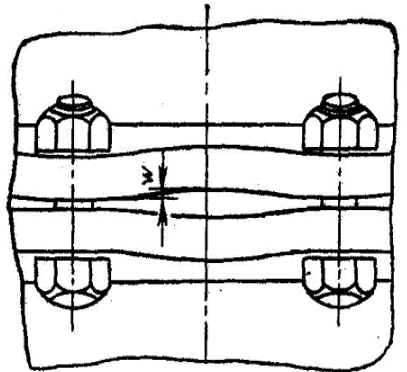

$\mathrm{b}$

1.2 pav. Srieginès jungties lenkimas dèl flanšo deformacijų (a), flanšu deformacija tarpuose tarp varžtu (b)

Fig. 1.2. Bending of threaded connection due to flange deformation (a), flange deformation in the midst of bolts (b) 
1.1 a paveiksle parodyta slègio indo dangčio tvirtinimas smeigèmis. Induose naudojamos ịvairios tarpinės ir įvairios jų prispaudimo konstrukcijos (1.1 b, c, d). Tarpas, kuris lieka tarp tarpinę prie korpuso prispaudžiančio žiedo ir korpuso sudaro galimybę nemažam smeigès lenkimui. 1.2 paveiksle parodyti flanšų lenkimas dviem kryptimis. Kai slègio inde ratu išsidèsčiusios srieginès jungtys įveržtos nevienodai arba nevienodai atsipalaiduoja eksploatacijos metu, flanšų tarpusavio poslinkiai $w(1.2 \mathrm{~b})$ abipus smeigès tampa taip pat nevienodi. Dèl to srieginè jungtis apkraunama papildoma, kartais nenumatyta, lenkimo apkrova.

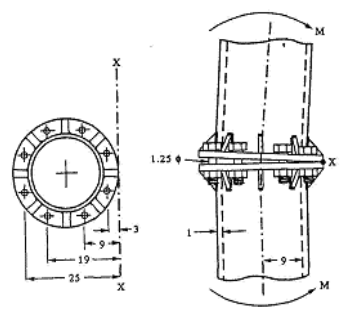

a

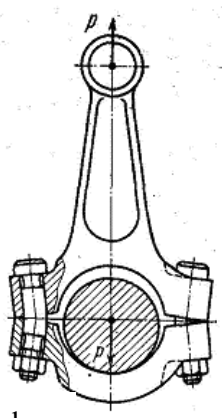

b

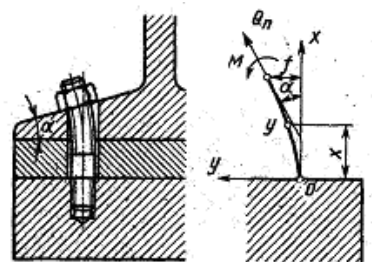

C

1.3 pav. Vamzdžio flanšo lenkimas (a), švaistiklio varžtų lenkimas (b), varžto lenkimas statybinèje konstrukcijoje (c)

Fig. 1.3. Bending of pipe (a), bending of connecting - rod bolt (b), bending of bolt of build structure (c)

Papildoma lenkimo apkrova srieginèms jungtims tenka ir tais atvejais, kai atsiradęs lenkimo momentas veikia visą konstrukciją. Toks cilindrinio bokšto lenkimas parodytas 1.3 a paveiksle (Bickford 1995). Mašinu gamybos srityje srieginių jungčių lenkimą gerai iliustruoja (1.3 b pav.) lenkiamos švaistiklio smeigès (Blaer 2007). Statybinèse konstrukcijose (1.3 c pav.) srieginių jungčiu lenkimas atsiranda dèl veržlès atraminių plokštumų nestatmenumo srieginès kiaurymès, esančios vienoje iš jungiamų detalių, ašiai. Arba atvirkščiai, dèl netiksliai suformuotų srieginès kiaurymès ašių, kai kreivai išgręžtos srieginès kiaurymės ašis nèra statmena atraminei veržlès plokštumai (Биргер, Иосилевич 1990). Statybinių konstrukcijų srieginès jungtys ir kniedès dažnai patiria lenkimą sąveikaudamos su jungiamais strypiniais elementais (Daniūnas, Urbonas 2007, 2008).

Kalnakasybos pramoneje atsakingos srieginės jungtys naudojamos masyvioms mineralų malimo būgno dalims sujungti. Dèl labai masyvaus bei pripildyto mineraline žaliava būgno (jo skersmuo $\mathrm{D}>10 \mathrm{~m}$ ), sukimosi režimo pokyčių (sukimosi dažnis pasiekia $10 \mathrm{sūk} / \mathrm{min}$ ), srieginès jungtys apkraunamos didelèmis ašinėmis ir lenkimo ciklinèmis apkrovomis (Leonavičius 1999). 


\subsection{Apkrovos pasiskirstymas sriegyje}

Pirmasis apkrovos pasiskirstymo sriegio vijose teorini sprendini pateike 1902 metais N. Žukovskis. Jis srieginę jungti nagrinejjo, kaip strypinę diskretinę sistema, kurioje veržle turi $n$ stačiakampès formos vijų, patiriančių kirpimą. Jis pirmasis nustatè, kad pirmajai vijai tenka didžiausia apkrova. Vèliau (apytikriai po 30 metu) analogiškus modelius su žiediniais elementais, schematizuojančiais atskiras vijas, kaip nurodyta darbe (Birger 1990), nagrinëjo Žake, E. Jacquet, L. Maduška, K. Kolenčiuk, Weber ir kiti. Šių autorių darbuose jau įvertinamas platesnis vijų formų ir deformacijų spektras, o sprendiniai gauti sprendžiant kanonines lygčių sistemas, siejančias gretimų vijų deformacijas. Šiuose darbuose nustatoma apkrova tenkanti kiekvienai vijai, nepaisant, kad ji netolygiai pasiskirsto ir vienos vijos ribose.

Vèliau 1948 metais, praktiškai vienu metu Sopwith ir Birgeris, kaip nurodyta darbe (Birger 1990), pasiūlè modelius, kuriuose sriegis yra ne atskirų vijų visuma, bet yra nepertraukiamas sriegio paviršius tolygiai einantis i veržlès giluma. Toks modelis yra arčiau tikrovès. Jis sudare galimybę atsisakyti baigtinių skirtumų metodo lygčių bei panaudoti lengvai išsprendžiamas diferencialines lygtis. Šie analitiniai modeliai yra labiausiai populiarūs ir literatūroje dažniausiai naudojami atliekant palyginimus su rezultatais gaunamais eksperimentiniais ir baigtinių elementų metodais.

D. G. Sopwith, nagrineddamas sriegines jungtis, gavo sprendini:

$$
\frac{\omega}{\omega_{m}}=\frac{\theta_{e} e^{(1-x) \cdot \lambda \cdot \theta}}{\sinh \theta}(\cosh x \theta-\lambda \cdot \sinh x \theta),
$$

čia $\omega, \omega_{m}-$ vijų apkrovos intensyvumai: pirmasis ties normalizuota koordinate $x$, atskaitant ją nuo veržlès atramos, antrasis - vidutinè jo reikšmé (visos jègos santykis su vijų kontakto ilgiu pagal sraigtinę linija), $\theta_{e}, \theta=\theta(h), \lambda$ - parametrai, kurie išreiškia tam tikrus jungties detalių geometrinių dydžių jų standumo ir vijų paslankumo koeficientų derinius. Vijų paslankumo koeficientų išraiškos čia gautos nagrinejjant sriegi kaip trumpą ir labai plačią konsolę, turinčią ekvivalentišką sriegio profiliui kintamą skerspjūvị. Jèga $\omega$ pridedama lygiagrečiai jungties ašiai vijos nuolydžio viduryje.

Pagal D. G. Sopwith modeli nustatytą apkrovos pasiskirstymą srieginiai jungčiai su gniuždoma veržle Patterson ir Kenny (1986) lygino su rezultatais, gautais eksperimentais tiriant trimačius fototampriuosius modelius. Eksperimentai parodè, kad analitiniu būdu gautos pirmujų vijų apkrovos pastebimai viršija atitinkamas eksperimentines apkrovų reikšmes. Buvo padaryta išvada, kad šis skirtumas atsirado dèl neịvertintos iš sukibimo išeinančių kraštinių jungties vijų itakos, kur vijos yra sukibusios ne visu profiliu. 
Norėdami įvertinti šią itaką, Patterson ir Kenny (1986) baigtiniu elementu metodu nustatè ir patikslino visu profiliu sukibusių vijų paslankumo koeficientą $\gamma$ ir šio koeficiento kintamas reikšmes, kai jos yra sukibę ne visu profiliu. Norèdami patikslinti apkrovos pasiskirstymą vijose, diferencialinę D. G. Sopwith lygti jie sprendè pasitelkę skaitinị Rungès - Kutto - Mersono iteracini metodą. Taip gauti rezultatai pakankamai gerai atitiko minètuosius eksperimentinius duomenis. Taip pat E. A. Patterson ir B. Kenny nustatè, kad visu profiliu sukibusių standartiniu vijų paslankumo koeficiento $\gamma$ reikšmé, nustatyta BE metodu visų jungties elementų tampraus deformavimo atveju, yra 3,5 kartus didesnè už apskaičiuotą pagal D. G. Sopwith teoriją.

Birgerio diferencialinès lygties sprendinys gniuždomos veržlès atveju išreiškiamas taip:

$$
q(z)=\frac{Q m}{\operatorname{sh}(m H)} \operatorname{ch}(m z),
$$

čia $q(z)$ - vijų apkrovos intensyvumas, $z$ - pjūvio koordinatè, atskaitant nuo laisvojo veržlès galo, $Q$ - visa ašinè jèga, tenkanti srieginei jungčiai, $m=\sqrt{\beta / \gamma}-$ koeficientas, ivvertinantis kartu varžto šerdies, veržlès sienelès ir vijų standumus, $\gamma$ - vijų poros paslankumas, $H$ - veržlès aukštis.

Nustatant $\gamma$, Birgerio teorija grindžiama prielaida, kad itempimų būvis vijoje yra toks pat, kokị turi pleišto pavidalo strypas, kai jo vieną šoną (nuolydi) veikia tolygiai išskirstyta apkrova. Varžto ir veržlès vijų paslankumo išraiškas Birgeris gavo, pritaikęs Moro poslinkių skaičiavimo būdą.

Tam atvejui, kai ivvertinamos varžto ir veržlès kūnų skersinès deformacijos, Birgeris pateikia sprendinị:

$$
q(z)=e^{n(H-z)} \frac{Q}{\operatorname{sh}\left(m_{0} H\right)}\left[m_{0} \cdot \operatorname{ch}\left(m_{0} z\right)-n \cdot \operatorname{sh}\left(m_{0} z\right)\right],
$$

čia $m_{0}=\sqrt{m^{2}+n^{2}}, n=-\varepsilon /(2 \gamma), \varepsilon$ - varžto šerdies ir veržlès sienelès skersinių deformacijų suma.

Skaičiavimai parodè, kad įvertinus varžto šerdies ir veržlès sienelès skersines deformacijas, apkrovos pasiskirstymas vijose standartinejje jungtyje pagerèja mažiau nei $1 \%$. Taigi praktiniam skaičiavimui gali būti naudojama paprastesnè (1.2) išraiška.

Shimotsuma (1973) deformacijų ir poslinkių darnos diferencialinès lygties sprendini pateikia kintančios varžto ašinès įražos $F(z)$ pavidalu:

$$
F(z)=F_{b} \frac{\sinh (\lambda z)}{\sinh (\lambda L)}
$$


čia $z$ - varžto skerspjūvio koordinatè, $F_{b}$ - visa jèga, tenkanti varžtui, $\lambda$ - srieginès jungties elementų kompleksinis standumo rodiklis, $L$ - jungties ilgis. Nesunku pastebèti, kad (1.4) reiškinys yra labai panašus i (1.2) lygties integralą.

Čia galima paminèti dar keletą darbu (Hase 1980, Miller, Marshek et al. 1983), kuriuose taip pat pateikta analitiniu apkrovos pasiskirstymo sriegio vijose modelių, sudarytu taikant srieginès jungties elementų tampriujų deformacijų ir poslinkių darnos principą. Šiuose darbuose nenagrinejjama išeinančių iš sukibimo kraštinių srieginès jungties vijų įtaka, o didžiausia apkrova tenka pirmajai viju porai, išsidèsčiusiai ties gniuždomos veržlès atrama. Pirmosios vijų poros apkrovos intensyvumo santykiai su vidutiniu intensyvumu $q_{\max } / q_{m}$ srieginėms jungtims M10 arba M12 apytikriai nustatyti pagal minètuosiuose darbuose pateiktą grafinę medžiaga, yra šie: 2,93 - Sopwith, 2,64 - Birger, 2,4 - Hase, 2,35 - Shimotsuma, virš 2,55 - Miller. Baigtinių elementų metodu nustatytos pavojingujų vijų apkrovos yra pastebimai mažesnès (Zao 1998, Malinovskij 2001, Liao et. al. 2009). Santykio $q_{\max } / q_{m}$ reikšmių skirtumai yra susiję su skirtingais analitiniais būdais, kuriuos naudojant apskaičiuojami varžto (smeigès) ir veržlès vijų paslankumai. Visi minètieji autoriai varžto šerdies ir veržlès sienelès deformacijas bei ašinius poslinkius skaičiuoja praktiškai vienodai, remdamiesi klasikiniais medžiagų mechanikos metodais. Galima daryti prielaidą, kad sudarant analitinius modelius, didžiausių sunkumų atsiranda analitiškai aprašant mažos iškyšos - sriegio danties ašinius poslinkius. Visi žinomi analitiniai modeliai visai nepaiso deformacinių reiškinių, kurie atsiranda vijų kontakte ir paviršiniuose vijų kūgio sluoksniuose. Todèl, nustatant vijų paslankuma, atsiranda papildomos paklaidu.

Ašinès apkrovos pasiskirstymo vijose analitinis modelis, ivertinantis tampriai plastinių deformacijų atsiradimą vijose ir ivijų itaka, pateiktas darbe (Selivonec, Krenevičius 2004). Ivijomis čia vadinamos ne visu profiliu sukibusių vijų poros, esančios jungties kraštuose. Šis modelis remiasi vienos viju poros tempimo diagrama, kuri gaunama eksperimentiškai - tempiant specialią jungti, turinčią vieną sukibusių vijų porą. Iš šios diagramos yra nustatomi vijų deformavimo rodikliai: vijų paslankumai, atitinkantys tiesinę ir netiesinę diagramos dali, takumo jègos intensyvumas $q_{y}$ ir vijų nukirpimo jègos intensyvumas $q_{u}$. Pasitelkus šiuos rodiklius, vijų ilinkiai aprašomi tiesinemis lygtimis. Toliau remiantis šiomis lygtimis ir Birgerio teorija, darbe gaunama išraiška vijų apkrovos intensyvumui $q(z)$ skaičiuoti uždaroje formoje ir tuose jungties ruožuose, kuriuose visu profiliu sukibusios vijos deformuojamos tampriai plastiškai:

$$
q(z)=m_{p} \cdot Q_{v} \cdot \operatorname{sh}\left(m_{p} z\right)+q_{y} \cdot \operatorname{ch}\left(m_{p} z\right)
$$


čia $m_{p}=\sqrt{\beta / \gamma_{p}}$ - jungties elementų deformavimo rodiklis, $\beta$ - varžto ir veržlès kūnų standumo koeficientas, $\gamma_{p}$ - tampriai plastiškai deformuotų vijų poros paslankumas - tiesès, aproksimuojančios netiesinę vienos vijų poros tempimo diagramos pradinę dali, pasvirimo kampo kotangentas, $Q_{v}=q_{y} \cdot \operatorname{th}\left(m\left(H-H_{2}\right)\right) / m$, $m$ - tas pats kaip ir lygtyje (1.2), $H$ - visas jungties aukštis, $H_{2}$ - tampriai plastiškai deformuotų vijų ruožo ilgis.

Tam atvejui, kai, be vijų, tampriai plastiškai pradeda deformuotis ir varžto šerdis, darbe (Krenevičius, Leonavičius 2008) pateiktas toks sprendinys:

$$
\begin{gathered}
q(z)=\left(\frac{m_{p}^{2}}{m_{u}}\right) \cdot Q_{y} \cdot \operatorname{sh}\left(m_{u} z\right)+q_{0} \cdot \operatorname{ch}\left(m_{u} z\right), \\
q_{0}=\frac{m_{u}^{2} \cdot\left(Q-Q_{y}\right)+m_{p}^{2} \cdot Q_{y} \cdot\left(1-\operatorname{ch}\left(m_{u} H_{3}\right)\right)}{m_{u} \cdot \operatorname{sh}\left(m_{u} H_{3}\right)},
\end{gathered}
$$

čia $Q_{y}$ - jèga, kurią pasiekus, varžto šerdis pradeda deformuotis tampriai plastiškai, $m_{u}$ - koeficientas, apimantis veržlès tampraus ir vijų bei varžto šerdies tampriai plastinio deformavimo rodiklius, kuriuos šie elementai turi ruože $H_{3}$. Čia $H_{3}$ - ruožo ilgis, kuriame vijų poros ir smeigès šerdis yra deformuoti plastiškai.

Šių darbų (Selivonec, Krenevičius 2004, Krenevičius, Leonavičius 2008) privalumas yra tas, kad panaudojus labai paprastą eksperimentą viju poru paslankumui nustatyti, išvengiama didelių paklaidų, kurios atsiranda skaičiuojant vijų paslankumo reikšmes analitiškai. Panaudojus nagrinèjamą analitinį modelị ir eksperimentines vijuc paslankumo reikšmes, nustatytos santykio $q_{\max } / q_{m}$ reikšmès standartinèms jungtims M16, M20, M30 yra artimos 1,6 ir yra nedaug - apie 4 \% mažesnès už reikšmes, kurias BEM metodais gavo Zao (1998) ir Malinovskij (2001). Reikia pastebèti, kad Zao ir Malinovskij metodikos ivertina netiesinius reiškinius vijų kontakto zonose ir plastinių deformacijų atsiradimą vijų paviršiaus sluoksniuose. Ivertindami plastinių deformacijų itaka, labai panašių rezultatų baigtinių elementų metodu gavo ir Liao (2009). Iš čia matyti, kad eksperimentinių vijų paslankumo reikšmių panaudojimas (Selivonec 2004) analitiniame modelyje pasiteisino.

Literatūroje nerasta ašinès jègos pasiskirstymo sriegyje analitinių modelių, kuriuose būtų nagrinèjamos sriegio vijų deformavimo savybès, pasireiškiančios veikiant kartotinei apkrovai. Jeigu vijų savybės pasikeičia pakartojus apkrovima, tas turi būti ịvertinta nustatant jungties elementų ciklinio apkrovimo parametrus.

Apkrovos pasiskirstymas lenkiamos jungties sriegyje. Tenzometrijos metodu išilginių deformacijų kitimą tempiamų ir tempiamų - lenkiamų (necentriškai tempiamų) smeigių nuo M39 iki M110 šerdyse tyré A. Speičys ir 
M. Leonavičius (Speičys, Leonavičius 1999). Smeigès šerdies išorinio sluoksnio išilginès deformacijos matuojamos mažais tenzojutikliais (matavimo bazè 0,5$1 \mathrm{~mm}$ ), iklijuotais išilginiame smeigès griovelyje taip, kad yra imanoma užsukti veržlę. Išmatuota išorinio smeigès šerdies sluoksnio deformacija vijų sukibimo srityje, esant lenkimui, leidžia nustatyti smeigès šerdies nominalių maksimalių itempių kitimą visame jungties ilgyje. Tačiau vijų apkrovos nèra matuojamos tiesiogiai. Kadangi vijų apkrovos ir nominalių smeigès šerdies kitimo dèsningumai yra skirtingi, ypač jungties kraštuose, tai tiksliai perskaičiuoti gautus rezultatus ir nustatyti vijų apkrovas yra keblu. Lenkimo atveju išilginis smeigès griovelis su tenzojutikliais yra lenkimo plokštumoje ir eliminuoja vijų sukibimą griovelio srityje per visa jungties ilgi, t. y. ten, kur nesant griovelio vijos turi ekstremalias apkrovas. Tai ineša papildomų paklaidų, kurių ivvertinimo metodikos literatūroje nerasta. Gauti rezultatai parodè, kad lenkimo plokštumoje smeigès nominalūs ekstremalūs îtempiai priešingose smeigès pusèse yra labai skirtingi. Tuomet akivaizdu, kad zonose, kuriose nominalūs tempimo ir lenkimo itempiai sumuojasi, vijų apkrovos intensyvumai taip pat yra didžiausi.

Analitiškai apkrovos pasiskirstymas tarp sriegio vijų, kai jungtị vienu metu veikia ašinė ivveržimo jejga ir skersinis jungiamų lakštu poslinkis nagrinejjamas darbe (Yazawa, Hongo 1988). Dèl skersinio jungiamų lakštu poslinkio varžtas patiria skersinę apkrovą ir lenkimą (1.4 pav.). Nominalus lenkimo momentas tenkantis varžtui nustatomas eksperimentais, pagal tenzojutiklio parodymus (1.5 pav.).

Apkrovos pasiskirstymo vijose funkcija $p_{z}$ čia yra išreikšta laipsnine eilute:

$$
p_{z}=a_{0}+a_{1} \theta+a_{2} \theta^{2}+\left(b_{0}+b_{1} \theta+b_{2} \theta^{2}\right) \cos \theta,
$$

čia $\theta$ - sriegio sraigtinès linijos spindulio kampas arba išskirstytos vijos apkrovos pridèties koordinatè, $a_{i}$ ir $b_{i}(\mathrm{i}=0,1,2)$ - ieškomieji koeficientai, kurie atitinkamai įvertina ịveržimo ir lenkimo apkrovų poveikius.

Varžto vidiniai lenkimo momentai yra išreikšti algebros lygtimis per viju apkrovas $p_{z}$. Yazawa ir Hongo lygindami varžto kampinius poslinkius su kampiniais poslinkiais, apskaičiuotais naudojant eksperimentais gautą lenkimo momento reikšmę, ir dar kraštinių sąlygu lygtis, nustatè laipsninès eilutès koeficientų reikšmes.

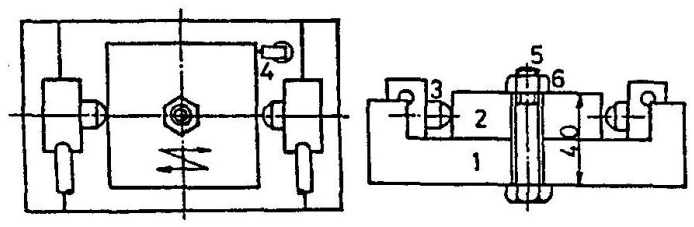

1.4 pav. Iveržto varžto apkrovimas skersine jèga ir lenkimo momentu Fig. 1.4. Loading of tight bolt by shearing force and bending moment 


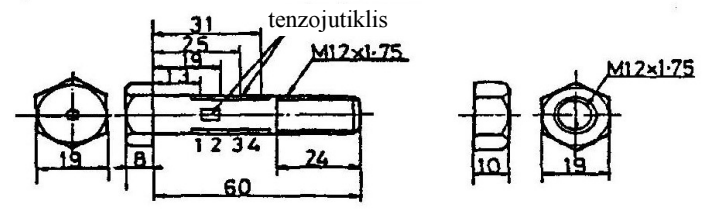

1.5 pav. Bandomasis važtas ir veržlè

Fig. 1.5. Testee bolt and nut

Tai empyrinis būdas, kurio didžiausias trūkumas yra tas, kad varžto šerdies kampiniai poslinkiai nèra susieti su vijų ịlinkiais ir vijų deformavimo charakteristikomis. Veržlès sienelès lenkimas čia taip pat nevertinamas. Taigi šis modelis nèra paremtas srieginès jungties elementu deformacijų ir poslinkių suderinamumu.

Kiti analitiniai (Bulatović, Jovanović 2000, Sawa et al. 1987) ir baigtinių elementų metodai (Mathan, Prasad 2008), kurie ivertina ir aprašo srieginių jungčių lenkima, iš esmès yra skirti išorinių mazgo apkrovų persiskirstymo tarp jungiamų detalių ir jas suspaudžiančios srieginès jungties ịvertinimui. Tokio pobūdžio modeliai nagrinejja varžto ar smeigès stiebo illinkių ir suspaudžiamų detalių deformacijų bei poslinkių suderinamumą, nepaisydami sriegio vijų deformacijų. Pagrindinis tikslas yra tinkamai suspausti jungiamas detales, neleidžiant vienai detalei pasislinkti kitos atžvilgiu, arba užtikrinti slèginių indų sandarumą. Šie modeliai dažniausiai yra tas šaltinis, kuris tiekia pradinius duomenis apie apkrovas tiesiogiai tenkančias srieginėms jungtims, kai atliekami jų stiprumo skaičiavimai.

\section{3. [tempių koncentracija sriegio vijų pašaknyje}

Literatūroje dažniausiai nagrinèjamose konstrukcijose visų i̇veržtų ir lenkiamų arba necentriškai tempiamų smeigių nominalūs ašiniai įtempiai yra didesni už nominalius itempius, atsirandančius dèl lenkimo. Todèl praktiškai visose analitinèse skaičiavimo metodikose vietiniai tamprieji itempiai smeigių sriegio idubose nustatomi, sudauginus suminius nominalius įtempius ir įtempių koncentracijos koeficienta, nustatytą tik ašinio tempimo atvejui.

Vijų apkrovas ir tampriuju itempimų koncentracijos koeficientus $\alpha_{\sigma}$ jų i̇dubose tampraus deformavimo atveju, BE metodu srieginei jungčiai M24x3 ( $H=0,8 \cdot d)$ apskaičiavo K. Maruyama (Maruyama 1974). Pirmajai vijai, esančiai ties gniuždomos veržlès atrama tenka didžiausias apkrovos intensyvumas, čia $\mathrm{q}_{\max } / \mathrm{q}_{\mathrm{m}} \approx 2,3$ ir $\alpha_{\sigma}=4,0-4,3$. K. Maruyama panaudodamas varinių dangų metodą eksperimentais patikrino skaičiavimo duomenis. Jis parodé, jog itempimų 
koncentracijai didelès itakos turi sriegio vijos įdubos apvalinimas bei paklaidos, susijusios su sriegio žingsniu, o sriegio profilio kampo paklaidos daro nedidelę itaką. Panašią reikšmę - 4,2 baigtinių elementų metodu gavo ir Muhammad Tandur ir Magami (2008) ašinio jungties apkrovimo atvejui.

Baigtinių elementų metodu standartinei jungčiai M30x3,5 $(H=0,8 \cdot d)$ E. Dragoni (Dragoni 1994) gavo $\alpha_{\sigma}=5,15$. Darbuose (Dragoni 1994, 2011) ISO standarte numatytoms srieginèms jungtims gauta tampriojo itempimų koncentracijos koeficiento $\alpha_{\sigma}$ priklausomybè nuo nominalaus skersmens ir žingsnio santykio $d / P$. Pagal šia priklausomybę, kuri pateikta grafiškai, didejjant $d / P$ didèja ir $\alpha_{\sigma}$. E. Dragoni (Dragoni 1997) efektyvuji itempimų koncentracijos koeficienta siūlo skaičiuoti pagal formulę:

$$
k_{e f}=\left(d / d_{3}\right) \cdot\left[1+q_{p} \cdot\left(\alpha_{\sigma}-1\right)\right],
$$

čia $d$ ir $d_{3}$ - nominalus ir vidinis varžto sriegio skersmuo, $q_{p}$ - medžiagos jautrumo ciklinei apkrovai koeficientas, $\alpha_{\sigma}$ - teorinis itempimų koncentracijos koeficientas, randamas nomogramoje priklausomai nuo santykio $d / P$.

T. Fukuoka darbe (Fukuoka, Takaki 1998), taip pat ir kai kurie kiti autoriai, pvz. M. Leonavičius (1999), akcentuoja įtempimų būvio skirtumus, atsirandančius dèl skirtingo jungčiu įveržimo būdo. Vienas iš būdų, kai ịveržimas vykdomas hidrauliniais irengimais ištempiant smeigę arba ją pakaitinant. Kitas - kai veržle i̇veržiama sukimo momentu. Antruoju atveju srieginejje jungtyje plastinès deformacijos gaunamos anksčiau ir plinta kitaip, nei pirmuoju atveju. Dél trinties Iveržimo sukimo momentu atveju plastinès deformacijos visose vijose iš esmès gaunamos tuo pat metu, vèliau apima visą srieginį sluoksnị ir per visą vijų sukibimo aukštị plinta smeigès centro link.

Šiuo metu srieginiu jungčių mažaciklio ilgaamžiškumo skaičiavimo normos (ASME Code 1995), nustatant vietinius itempimus varžtu arba smeigių sriegio idubose, nenumato apkrovų pasiskirstymo vijose skaičiavimo stadijos. Normatyve (ASME Code 1995) bet kurios konstrukcijos jungčiai numatyta taikyti vienodo didumo itempimų koncentracijos koeficientą $\alpha_{\sigma}=4$. Normose (RF normos 1989) tamprusis įtempimų koncentracijos koeficientas skaičiuojamas pagal formulę:

$$
\alpha_{\sigma}=K_{s} K_{w}(1+\bar{\gamma} \cdot \sqrt{(P / R}),
$$

čia $\bar{\gamma}=1,57$, pagal (Birger 1990) rekomendaciją, $P$ - sriegio žingsnis, $R$ - idubos apvalinimo spindulys. Koeficientai $K_{s}$ ir $K_{w}$ ivertina išorinès detalès tipą ir jungties aukšti. Standartinei $(H=0,8 \cdot d)$ gniuždomai veržlei $K_{w}=1$ ir $K_{s}=1$. Kai $H=1,25 \cdot d$, tai $K_{s}=0,90$. Tempiamai veržlei - kai $H=d$, tai $K_{s}=0,75$. Jungtims smeige - korpusas: $K_{w}=0,7-1,0$, kai $R_{m k} / R_{m s}=0,5-1,0$, kur $R_{m k}$ ir $R_{m s}$ 
yra korpuso ir smeigès medžiagų stiprumo ribos. Normose (RF normos 1989) dar yra numatytas medžiagos jautrumo ciklinei apkrovai ịvertinimas, kai vietinių itempimų sriegio i̇duboje ciklo amplitudè yra mažesnè už medžiagos takumo ribą. G. Josilevičius (1981) remdamasis BEM skaičiavimais, siūlo taikyti formuleje (1.10) koeficientą $\bar{\gamma}=1,10$. Tikrindami formulès (1.10) taikymo galimybes didelio gabarito smeigès M190x6 jungčiai su veržle ir su korpuso sriegiu BE metodu (Komarova, Kuzmin et al. 2007) nustatè, nedideli (5-7) \% įtempių koncentracijos koeficientų reikšmių, nustatytų abiem metodais, skirtumus.

(Knez, Glodez 2009) hidraulinio įrenginio stūmoklio koto sriegiui įtempių koncentracijos koeficientus skaičiavo pagal tokią analitinę formulę

$$
K=K_{1}+K_{2}(2 h / D)+K_{3}(2 h / D)^{2}+K_{4}(2 h / D)^{3},
$$

čia $K_{1}, K_{2}, K_{3}, K_{4}$, koeficientai, apskaičiuojami pagal pateiktas analitines išraiškas ir jų didumas priklauso nuo santykio $h / R_{r}, h$ yra vijos aukštis, $D$ nominalus skersmuo, $R_{r}$ yra sriegio įdubos apvalinimo spindulys. Knez M. ir jo bendraautoriai nustate ir patvirtino, naudodami baigtinių elementų metoda, kad mažesnio žingsnio sriegyje susidaro didesnè itempių koncentracija, lyginant su didesnio žingsnio atveju.

Visų nagrinètujų tyrimų autorių nuomonè dèl ịtempių sriegio įdubose sutampa - jie atsiranda dèl ašinès iražos ir vijos lenkimo (kai įveržimui nenaudojamas sukimo momentas, o išorinè apkrova tik ašinè). R. Heywood (1969) vietiniams įtempiams varžto sriegio įduboje nustatyti pateike formulę, ivvertinančią minètuosius du poveikius atskirai:

$$
\sigma=\sigma_{0}+\frac{\sigma_{l}}{1+c\left(\sigma_{0} / \sigma_{l}\right)}
$$

čia $\sigma_{0}=\alpha_{\sigma} \sigma_{n}$ - maksimalus įtempis sriegio įduboje, atsirandantis dèl ašinès jègos, $\sigma_{n}-$ nominalus itempis, $\alpha_{\sigma}$ - periodiškai suformuotu (sriegio žingsniu) negilių žiedinių griovelių itempių koncentracijos koeficientas, nustatomas panaudojus Neiberio formulę, $c=[(60-\alpha / 4) / 44]^{2}, \quad \alpha-$ sriegio profilio kampas (laipsniais), $\sigma_{l}$ - maksimalus itempis įduboje dèl vijos lenkimo, nustatomas pagal empyrinę formulę:

$$
\sigma_{l}=\frac{F_{v}}{P}\left[1+0,26 \cdot\left(\frac{e}{R}\right)^{0,7}\right] \cdot\left(\frac{1,5 a}{e^{2}}+\frac{0,45}{\sqrt{b e}}+\frac{\sin \varphi}{2 e}\right),
$$

čia $F_{v}$ - koncentruota jèga, pridèta vijos kūgio šoniniame paviršiuje; $a, b$ ir $e-$ geometriniai parametrai, kurie susieja jègos kryptị su vijos kūgio geometrija (pateikti grafiškai), $\varphi$ - kampas tarp jègos krypties ir įubos lanko liestinès ties 
nagrinejjamuoju tašku. Formulè (1.13) pagrịsta rezultatais, gautais tiriant krumpliaračio dantų fototampriuosius modelius. Apskaičiuotos pagal (1.12) itempimų reikšmès yra šiek tiek didesnès už apskaičiuotąsiąs, panaudojant (1.10).

H. Neuber ir bendraautoriai (Neuber, Schmidt 1975) savo darbe, bet kurio sriegio įdubos taško vietini itempi gauna sumuodami jo dedamąsias:

$$
\sigma(\varphi)=\frac{\sigma_{z, \max }}{1+\sin ^{2} \varphi_{r}}+\frac{\sigma_{l, \max }}{1+\sin ^{2}\left(\varphi_{r}-\pi / 6\right)},
$$

čia $\sigma_{z, \max }$ ir $\sigma_{l, \max }$ - didžiausieji ịtempiai įduboje, kurie atsiranda dèl ašinès ịrąžos ir dèl vijos lenkimo pateikiamos išraiškos šiems itempiams skaičiuoti, $\varphi_{r}$ nagrinejamo įdubos taško kampine koordinatè, kurios reikšmè pavojingajam taškui nustatoma prilyginus nuliui formulès (1.14) išvestinę kampo atžvilgiu. Apskaičiuotos pagal (1.14) įtempių reikšmès yra 10-15\%, didesnès už apskaičiuotąsias, panaudojant (1.10).

Itempio dedamuju sumavimo principas salyginių tampriujų maksimalių itempių skaičiavimui pirmosios pavojingosios vijos įduboje taip pat panaudotas darbe (Махутов, et al. 1987):

$$
\sigma_{\max }^{*}=\sigma_{o}+\sigma_{l}=\frac{Q}{A_{s}} K_{0}+\frac{q_{\max } \cdot P}{f} K_{m},
$$

čia $Q$ - išorine jèga, tenkanti smeigei, $A_{s}$ - smeigès skerspjūvio plotas, apskaičiuotas pagal sriegio įdubą atitinkantị skersmeni, $q_{\max }-$ pirmosios vijos apkrovos intensyvumas, $P$ - sriegio žingsnis, $f$ - vijų kontakto ploto projekcija i plokštuma, statmeną jungties ašiai, $K_{0}$ ir $K_{m}$ - teoriniai itempių koncentracijos koeficientai dèl ašinès jègos ir atitinkamai vijos lenkimo. Nagrinèjamame darbe siūloma naudoti didžiausias koncentracijos koeficientų reikšmes, apskaičiuotas panaudojus N. Muschelišvili tamprumo teoriją: $K_{0}=2,0$ ir $K_{m}=1,95$, esant santykiui $d / P=23$. Šios reikšmès mažai kinta, esant minetajam santykiui intervale $15>d / P \leq 23$, o $\sigma_{\max }^{*}$ sumažeja iki $10-15 \%$, mažejant $d / P$ už nurodytojo intervalo ribų. Pasiremdami dar ir eksperimentiniais duomenimis, (Махутов, et al. 1987, Махутов 2005) darbo autoriai gniuždomos veržlès atvejui nurodo, kad bendrasis itempių koncentracijos koeficientas (kuris gali būti palyginamas su reikšmėmis gaunamomis pagal (1.10), yra intervale $3,8 \leq \alpha_{\sigma} \leq 4,3$, o tempiamos veržlès atveju $\alpha_{\sigma} \leq 3,2$. Panaudoję savo sudarytą ašinių apkrovų pasiskirstymo vijose modeli, Selivonec ir Krenevičius (2004) nustate $Q$ ir $q_{\max }$ reikšmes jungtims M20, M52 ir M110. Su šiomis reikšmèmis pagal formulę (1.15) apskaičiuoti sriegio vietiniai salyginiai tamprieji itempiai $\sigma_{\max }^{*}$ yra artimi (Zhao 1998) baigtinių elementų metodu gautiems įtempiams. 
Necentriškai tempiamoms jungtims M30x3 darbuose (Burgute, Patterson 1994, 1995, Fessler, Jiong - Hua 1984, Kloos, Schneider 1984) itempių koncentracijos koeficientas buvo nustatytas eksperimentais fototamprumo metodu. Darbuose (Burgute, Patterson 1994) gauta maksimali itempiu koncentracijos koeficiento reikšmè pagal grafiką (1.6 pav.) yra $K \approx 4,5-4,8$. Taip pat čia yra nurodyta, kad šios reikšmès negalima laikyti vienintele galima reikšme, nes jos didumas gali keistis, kintant nominalių ašinių ir lenkimo itempių santykiui bei apkrovų pasiskirstymui vijose.

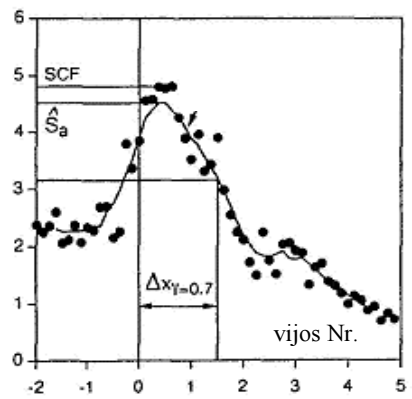

1.6 pav. Itempiu koncentracija jungties M30 vijose, veikiant necentrinei apkrovai

Fig. 1.6. Stress concentration in threads of joint M30 due eccentric loading

Nagrinejjant literatūra, susijusią su vietinių itempių sriegyje skaičiavimais, pastebèta, kad įtempių koncentracijos koeficientų reikšmès priklauso nuo apkrovos pasiskirstymo vijose. Dažnai dèl skirtingo apkrovos pasiskirstymo atskiri autoriai gauna skirtingas šių koeficientų reikšmes. Analitinès formulès, kurios vietiniu itempių reikšmes nustato taikydami atskirus koncentracijos koeficientus smeigès vijos ir smeigès šerdies apkrovų poveikio įvertinimui, detaliau atspindi sriegio apkrovimo ypatumus.

\subsection{Srieginių jungčių ciklinis ilgaamžiškumas}

Medžiagų ir elementų su įtempių koncentratoriais ciklinio stiprumo reiškiniai teoriškai ir eksperimentiškai plačiai nagrinèti L. F. Coffino, S. S Manson, R. W. Landgrafo J. Polako, H. Mughrabi, B. Pyttel, M. F. Horstemeyer, A. Seweryn, N. Machutovo, M. Daunio, A. Bražèno, H. Medekšos, A. Žiliuko, Ž. Bazaro, P. Krasausko darbuose. Šiuose darbuose nagrinèjami atominès ir struktūrinès sandaros, deformavimo savybių ir apkrovimo režimų itaka nuovarginiam irimui, irimo kriterijai konstrukcijoms su plyšiais bei nuovargio statistiniai reiškiniai. Strypinių elementų ir srieginių jungčių deformavima, ciklinį stipruma, prisitaikomumą ir atsipalaidavimą teoriškai ir eksperimentiškai tyre VGTU 
mokslininkai A. Čyras, J. Atkočiūnas, A. Daniūnas, R. Kačianauskas, V. Kagan, M. Leonavičius, A. Speičys, A. Krenevičius, S. Stupak, M. Šukšta, J. Selivonec, K. Vislavičius.

Nemažai darbų yra atlikta srieginių jungčių nuovargio eksperimentinių tyrimų srityje, veikiant ašinei ciklinei apkrovai. Šiuose tyrimuose nustatoma ivvairių faktorių itaka cikliniam ilgaamžiškumui: pvz., sriegio žingsnio, medžiagos, sriegio formavimo metodų įtaka, srieginès jungties gabaritų. Beveik visuose nagrinètuose darbuose eksperimentais nustatomas ciklinis ilgaamžiškumas iki visiško suirimo (Schmidt, Neuper 1997, Chen, Lee 1995, Якушев, Мустаев, et al. 1979, Majzoobi, Farrahi et al. 2005, Knez 2009;). Tačiau nagrinètuose darbuose pateikti smeigių ir varžtų lūžiai rodo, kad iš tikrujų egzistuoja dvi skirtingos ciklinio ilgaamžiškumo stadijos - iki plyšio atsiradimo smeigès sriegio įduboje ir plyšiui augant iki visiško smeigès suirimo.

Kituose darbuose eksperimentiniai tyrimai buvo vykdomi, veikiant ciklinei ašinei ir lenkimo apkrovai - pridedant tempiančią jëgą su ekscentrisitetu. Tokio bandymo schema parodyta 1.7 a paveiksle (Hobbs, Burgute 2000). Šiame darbe nustatomas tik apkrovimo ciklu skaičius iki visiško suirimo. Gauti rezultatai, išbandžius sriegines jungtis M12 jas tempiant su ekcentrisitetu, parodyti $1.7 \mathrm{~b}$ paveiksle.

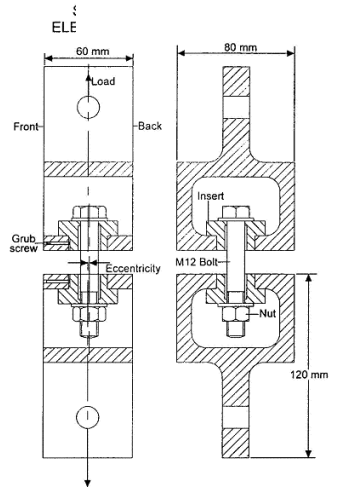

a

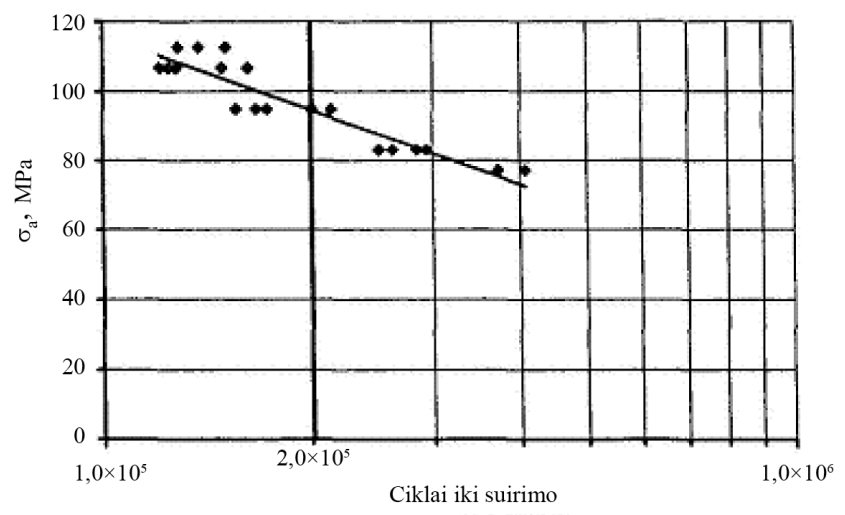

b

1.7 pav. Srieginės jungties ciklinis necentrinis tempimas: bandymo schema (a), nuovargio kreivè ir eksperimentiniai duomenys (b)

Fig. 1.7. Eccentric cyclic loading of threaded joint: test scheme (a), fatigue curve (b)

Darbuose (Korin et al. 2011) ir (Krenevičius, Leonavičius 2008), be apkrovimo ciklų skaičiaus iki visiško suirimo, nustatomas ir srieginių jungčių (veikiamų ašine cikline apkrova) ciklinis ilgaamžiškumas iki plyšiui atsirandant. Leonavičiaus ir Krenevičiaus darbuose jis nustatomas magnetiniu liuminescensiniu miltelių metodu. 

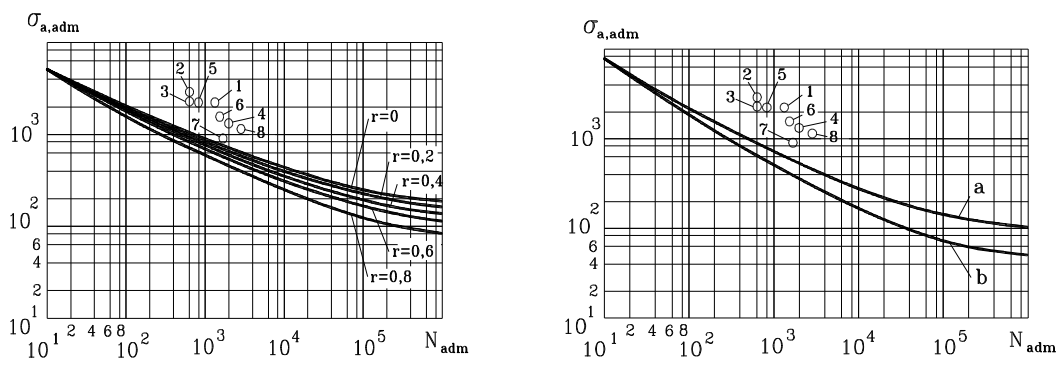

1.8 pav. Eksperimentinių duomenų palyginimas su normų nuovargio kreivėmis lenkiamai srieginei jungčiai M48×4: RF normos (a), ASME normos (b)

Fig. 1.8. Comparison experimental data with fatigue curves for bent threaded joint M48 $\times 4$ : standard of RF (a), standard of ASME (b)

Gauti rezultatai rodo, kad abi stadijos pagal trukmę yra ženklios, o irimo procesai yra gana skirtingi. Iki plyšio atsiradimo pažeidimai kaupiami sriegio idubose, o jau esant plyšiui - pažeidimai kaupiami medžiagoje plyšio viršūnès aplinkoje ir plyšys lètai plinta. Tokias pat stadijas šie autoriai eksperimentais nustate ir tais atvejais, kai sriegines jungtis veikia vienpusio ir dvipusio lenkimo ciklinė apkrova (Leonavičius, et al. 2006, Krenevičius, Leonavičius 1998). Ciklinio ilgaamžiškumo eksperimentiniai duomenys pagal plyšio atsiradimą ir visišką suirimą gauti srieginėms jungtims: M16×2, M48×4 ir M48×3(×4, ×5). Plyšio atsiradimo jungtyse M48 eksperimentinių duomenų palyginimas su normose (RF normos 1989) ir normose (ASME Code 1995) pateiktomis srieginių jungčių ciklinio ilgaamžiškumo kreivèmis atitinkamai parodytas 1.8 paveiksle. Iš pateiktų 1.8 paveikslo rezultatų matyti, kad eksperimentinès ciklinio ilgaamžiškumo reikšmès yra pastebimai didesnès (2-10 kartų) už reikšmes, kurias atspindi normų kreivès.

Darbe (Patterson 1990) pateiktas kelių skaičiavimo metodikų palyginimas, taikomų srieginių jungčių daugiaciklio stiprumo srityje. Bendras šių metodikų bruožas yra tas, kad srieginių jungčių patvarumo ribos nustatymas pradedamas apkrovų sriegio vijose pasiskirstymo skaičiavimais pagal Sopwith arba Birgerio formules. Šiu skaičiavimų rezultatai toliau naudojami vietinių itempių nustatymui pagal (1.12) ir (1.13) formules. Darbo pabaigoje šios metodikos ivertinamos, lyginant ilgaamžiškumo ir patvarumo ribos skaičiavimo rezultatus su eksperimentiniais duomenimis.

Norminèse metodikose, skirtose atominès energetikos įrenginiams, sunkiai apkrautų srieginių jungčių ir kitų konstrukcijų su koncentratoriais mažaciklis ilgaamžiškumas skaičiuojamas, naudojant Kofino, Mansono, Langerio tipo dvinares formules, kurios nariai išreiškia plastinę ir tampriają deformacijos ampli- 
tudès dedamąsias cikle. ASME Code (1995) srieginių jungčių mažaciklị ilgaamžiškumą nustato pagal skaičiuojamąsias ilgaamžiškumo kreives, kurios tikrinamos eksperimentiškai. Srieginèms jungtims šios kreivès apskaičiuotos, pagal Snow, Langer (1967) formulę:

$$
\sigma_{a}^{*}=\frac{A \cdot E}{N_{f} \cdot C}+S_{e},
$$

čia $\sigma_{a}^{*}$ - sąlyginių tampriujų vietiniu itempimų ciklo amplitudè, $E$ - tamprumo modulis, $N_{f}$ - skaičiuojamąsis ciklų skaičius, $A, C, S_{e}$ - parametrai, kurie priklauso nuo mechaninių plieno savybių ir apkrovimo ciklo rodiklių. ASME Code, sudarant skaičiuojamąsias ilgaamžiškumo kreives, irimo stadijos neišskiriamos. Todèl čia yra gana dideli atsargos koeficientai: $n_{N}=20$ ciklų skaičiui ir $n_{\sigma}=2$ sąlyginiams tampriesiems itempiams.

Rusijos Federacijos Normose (1989) srieginių jungčių mažaciklis ilgaamžiškumas nustatomas pagal skaičiuojamąsias ilgaamžiškumo kreives, arba, atliekant skaičiavimą pagal nustatytas formules. Šios formulès ir trumpas komentaras pateiktas šios disertacijos 4 skyriuje. Skaičiavimo rezultatams taikomi tokie atsargos koeficientai: $n_{N}=3$ ir $n_{\sigma}=1,5$. RF normineje metodikoje mažaciklis ilgaamžiškumas nustatomas pagal pirmają irimo stadiją - iki plyšio susidarymo itempimų koncentracijos zonose. Plyšio plitimo stadija nevertinama dèl padidintų reikalavimų saugumui. VGTU stiprumo mechanikos laboratorijoje RF normose pateikta formule jungčių ašinio mažaciklio apkrovimo atvejui buvo modifikuota, idiegus i ilgaamžiškumo skaičiavimo grandinę ašinès apkrovos pasiskirstymo vijose modelį ir remiantis 294 jungčių bandymų $\left(10^{2}-10^{6}\right.$ ciklų diapazone) rezultatais (Selivonec ir Krenevičius 2004, Krenevičius, Leonavičius 2008). Toks modifikavimas ženkliai priartino apskaičiuotas ciklinio ilgaamžiškumo reikšmes prie eksperimentinių rezultatų.

Disertaciniame darbe siekta lenkimo apkrovos pasiskirstymo modelio taikymo galimybę patikrinti, panaudojant tokią ilgaamžiškumo skaičiavimo metodiką, kuri jau būtų eksperimentiškai patikrinta srieginès jungties ašinio apkrovimo atvejui. Dèl šios priežasties lenkiamų jungčių mažaciklio ilgaamžiškumo skaičiavimui buvo pasirinkta modifikuota RF normų metodika (ketvirtas skyrius).

Nesunku pastebėti, kad norminès metodikos, ilgaamžiškumo skaičiavimo formulių pastoviujų koeficientų, išreikštų per mechaninių savybių rodiklius, taikymo galimybes, grindžia pačių srieginių jungčių eksperimentiniais tyrimais. Tačiau bendru atveju konstrukcijų elementams su koncentratorias (retkarčiais ir srieginèms jungtims) ciklinis ilgaamžiškumas tradiciškai nustatomas, taikant aprašančias dvinares formules, kurios aprašo medžiagos nuovargio kreives. Pastovieji koeficientai šiais atvejais nustatomi arba patikslinami standartiniu glotnių 
bandinių ciklinio apkrovimo tyrimais. Kaip argumentai $\mathfrak{i}$ šias formules įstatomi vietiniai itempiai arba vietinès deformacijos, kurie nustatomi atliekant tamprausplastinio būvio analizę pagal Neiberio, Glinkos, Machutovo, Daunio ar kitas atitinkamas taisykles. Srieginių jungčių atvejui tokị kelią formulių lygmenyje aprašè Honarmandi ir Behdinan (2005). Ilgaamžiškumo skaičiavimui jie panaudojo Smith - Topper - Watson vietinių deformacijų ir ciklų skaičiaus priklausomybę. Plastines vietines deformacijas ir tikruosius itempius jie nustate pagal Neiberio taisyklę, tam panaudoję tampriujų vietinių deformacijų ir itempių reikšmes, gautas baigtinių elementų metodu. Jų nustatytas tamprusis itempių koncentracijos koeficientas varžto sriegiui yra 3,34. Šis ilgaamžiškumo skaičiavimas gerai atitiko eksperimentinius duomenis diapazone $10^{5}-10^{6}$ ciklų. Tačiau apkrovų pasiskirstymo įtaka šiame skaičiavime liko tiesiogiai neišreikšta.

\subsection{Ciklinio ilgaamžiškumo padidinimas}

Literatūroje nagrinejjamus metodus, skirtus srieginių jungčių ciklinio ilgaamžiškumo padidinimui, galima suskirstyti $\mathfrak{i}$ tris grupes: technologiniai sriegio formavimo ir apdorojimo metodai, konstrukciniai metodai ir metodai, susiję su jungčių eksplotavimo technologija. Daugelis tradicinių metodų yra aprašyti knygose (Биргер, Иосилевич 1990, Bickford 1995, Heywood 1962, Якушев et al. 1979). Dažniausiai čia aprašomi technologiniai būdai, kurie taikomi įtempių koncentracijos sumažinimui sriegio įduboje - didinant įdubos apvalinimo spinduli, suformuojant liekamuosius gniuždymo ịtempius įduboje apspaudimu ritinèliais, naudojant šlifuotą sriegi vietoj ištekinto, efektyvesni termini apdirbimą arba mažinant jautrumą koncentracijai įdubos paviršiaus sluoksni paveikus lazerio spinduliais. Naujas technologinis būdas pasiūlytas darbe (Bergmann et al. 2010), kai smeigès skerspjūvyje suformuojama optimali metalo mikrostruktūros kaita taip, kad sriegio paviršiuje susidaro tąsus sluoksnis, kuris sumažina įtempių koncentracija.

Konstrukciniais metodais siekiama pagerinti apkrovų pasiskirstymą vijose taip, kad sriegio vietiniai itempiai visame jungties ilgyje būtų beveik vienodo didumo.

Šiam tikslui daugelyje atvejų siūlomos naujos veržlès arba sriegio vijos formos (Patterson, Kenny 1987, Venkatesan, Kinzel 2006, Honarmandi et al. 2005) arba siūlomi specialūs jungties detalių gamybai naudojamų medžiagų deriniai (Dragoni 1990, Motosh 1975). Tokiu būdu siekiama bent optimizuoti veržlès sienelès, smeigès šerdies ir vijų paslankumų santykius ir taip sumažinti pavojingujų vijų apkrovas.

Kitais atvejais pavojingujų pirmuju vijų apkrovos sumažinamos, suformavus tarpelius tarp vijų taip, kad veržlès gilumoje jie mažètų ir būtų didžiausi sri- 
tyje ties veržlès atrama. Tuomet apkrovus jungti, vijų apkrovos šioje srityje tampa mažesnèmis už apkrovas tenkančias vijoms, esančioms veržlès gilumoje. Todèl, smeigès šerdies ašinès iražos didumas, (nuo kurio taip pat priklauso sriegio vietiniai i̇tempiai) šioje srityje lieka didžiausias. Tokiu būdu vietiniai įtempiai visame vijų sukibimo ilgyje igauna panašias reikšmes. Vienais atvejais tarpeliai formuojami, naudojant veržles su kūginiu sriegiu, kuriose vidurinis sriegio skersmuo, tolstant nuo atraminès veržlès plokštumos i veržlès giluma, palaipsniui mažejja (Patterson, Kenny 1986). Kitais atvejais tarpelis atsiranda jungties apkrovimo procese besiplečiant veržlei, turinčiai specialią atraminès dalies formą, kuri ir priverčia ją plèstis (Fukuoka, Takaki 1998). Bendras konstrukcinių metodų trūkumas, kuris minimas literatūroje, yra tas, kad specialių detalių gamybos kaštai yra didesni, lyginant su standartinių detalių gamyba.

Metodams, susijusiems su tempiamų jungčių eksplotavimo technologija, pirmiausiai reikia priskirti smeigès ịveržimo itempiu padidinimą (Bickford 1995). Juos padidinus, sumažèja smeigès apkrovimo ciklo amplitudè ir padidèja ciklinis ilgaamžiškumas. Kitas metodas, priskirtinas šiai kategorijai, leidžia padidinti smeigès ciklini ilgaamžiškuma, periodiškai keičiant veržlès ir smeigès tarpusavio padètį eksploatacijos eigoje (Krenevičius et al. 2004). Čia kiekvieno kito eksploatacijos periodo metu vis kita smeigés vija yra pavojingiausioje jungties srityje. Tokiu būdu smeigès sriegio įdubose sukauptų ciklinių pažeidimų kiekis išlyginamas, o bendras galimas jų kiekis ženkliai padidèja. Taip pat apie 2-3 kartus padidejja ir smeigès ciklinis ilgaamžiškumas.

\subsection{Pirmojo skyriaus išvados}

1. Ivairiose pramonès šakose taikomų irenginių srieginès jungtys dažnai apkraunamos cikliniu lenkimu. Jų stiprumo skaičiavimo metodikos turi kuo tiksliau įvertinti lenkiamų jungčių deformavimo ypatumus.

2. Apkrovos ir itempiu pasiskirstymo vijose modelių taikymas skaičiuojant ilgaamžiškumą leidžia detaliai ịvertinti konstrukcinių veiksnių įtaką ịtempių didumui sriegio vijų pašaknyje. Galima prognozuoti, kad pavojingujų vijų apkrautų lenkimu apkrova gali keistis apie 10-30\% priklausomai nuo jungties konstrukcijos - taip, kai jungti veikia vien tik ašinè apkrova. Todèl apkrovos ir vietinių i̇tempių pasiskirstymo modelių įdiegimas į cikliškai lenkiamų jungčių ilgaamžiškumo skaičiavimo grandinę yra aktualus.

3. Siekiant ivertinti apkrovos pasiskirstymą vijose skaičiuojant srieginių jungčių ilgaamžiškumą, tikslinga vietinius sriegio įtempius skaičiuoti, naudojant dvinares išraiškas.

4. Yazawos lenkiamos jungties apkrovos pasiskirstymo vijose analitiniame modelyje nèra ịvertintas smeigès, veržlès ir sriegio vijų poslinkių suderinamu- 
mas, o veržlès ir vijų deformavimo visai nepaisoma. Literatūroje nerasta lenkiamos srieginès jungties modelių, kurie grindžiami jungties elementų poslinkių suderinamumu.

5. Sriegio vijų deformavimo savybės pakartotinio apkrovimo atvejams nèra anksčiau tirtos.

6. Žinomi eksperimentai rodo, kad cikliškai tempiamu - cikliškai lenkiamų jungčių ilgaamžiškumas iki plyšio atsiradimo yra apie 2-10 kartų didesnis už apskaičiuotą pagal normines RF (1989) ir ASME (1995) metodikas. Cikliškai tempiamu jungčių atveju, skaičiavimus ženkliai patikslina modifikuotos norminès mažaciklio ilgaamžiškumo skaičiavimo metodikos taikymas, kuri įvertina ašinès apkrovos pasiskirstymą vijose. Cikliškai lenkiamos jungties atvejui toks skaičiavimas netaikomas, nes anksčiau nebuvo sukurtų tinkamų modelių lenkimo apkrovos pasiskirstymui apskaičiuoti. 



\section{2}

\section{Viju poros deformavimo savybiu eksperimentinis tyrimas}

Šiame skyriuje aprašoma sriegio vijų poros tempimo bandymo metodika, bandiniai, įranga ir vijų deformavimo rodiklių nustatymo tvarka. Aprašytas anksčiau literatūroje nenagrinètas vijų poros deformavimo reiškinys, kuris pasireiškia vijų poros nukrovimo ir pakartotinio apkrovimo atvejais. Pateikiamos vijų poru paslankumo reikšmès nustatytos, atliekant jų nukrovimo ir pakartotinio apkrovimo bandymus. Skyriaus medžiaga panaudota atoriaus straipsnyje (Krenevičius, Juchnevičius et al. 2008).

\subsection{Viju poros tempimo bandymo metodas}

Detalus srieginès jungties apkrovos pasiskirstymo vijose skaičiavimas negali apseiti be smeigès (varžto) ir veržlès medžiagų bei sriegio vijų deformavimo rodiklių. Tokiame skaičiavime, tai būtini pradiniai duomenys. 
Vijų poros deformavimo procesą gali išreikšti vijų ịlinkių diagrama, panaši i medžiagos cilindrinio bandinio tempimo diagramą. Todèl vijų deformavimo ir stiprumo rodikliu nustatymui ivairiose deformavimo stadijose buvo naudojama eksperimentinè vijų poros įlinkių kreivè. Vijų poros tempimo eksperimentas su nukrovimais arba be jų, igyvendinamas pagal schema, sudarytą VGTU Stiprumo Mechanikos Bandymų laboratorijoje 2.1 paveikslas.

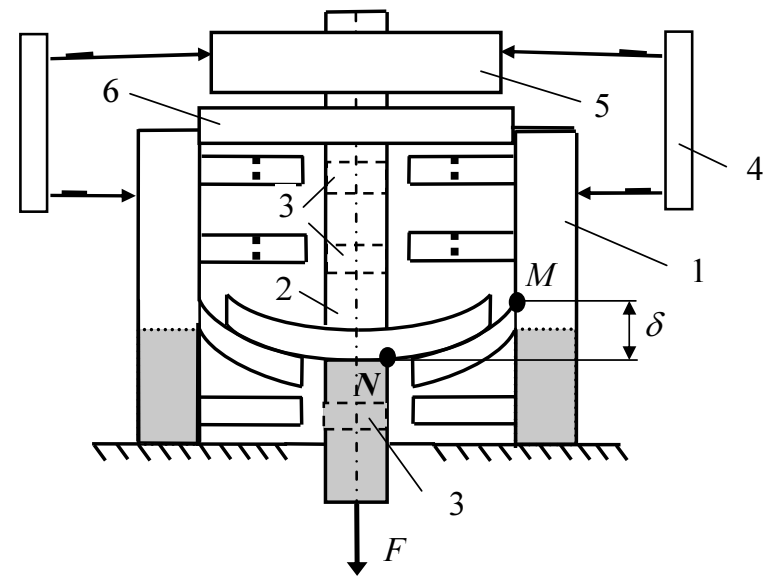

2.1 pav. Vijų poros tempimo bandymo schema

Fig. 2.1. Scheme of turn pair tension test

Specialia jungti, tempiamą jèga $F$, sudaro veržlè 1 ir smeigè 2 , turinti tik viena vija, likusią sriegyje pašalinus kitas vijas 3 . Veržlè 1 turi lygiagretu ašiai vidinį siaura griovelị, kad deformuojama būtų tik kontakte esanti jos vija. Šiame griovelyje yra smeigès vijos pradžia ir jos pabaiga. Deformometru 4 matuojamas smeigès šerdies ir veržlès sienelès tarpusavio poslinkis, kuris yra lygus vijų poros illinkiui $\delta$. Ilinkis $\delta$ lygus nuotoliui tarp taškų $N$ ir $M$. Šis nuotolis atsiranda tempiant jungti. Taškai $N$ ir $M$ prieš bandymą yra vienoje horizontaleje. Deformometro antgaliai ịremti i nedeformuojamus bandomosios veržlès 2 ir pagalbinès veržlès 5 paviršius. Pagalbinè veržlè užsukta ant smeigès ir jos atžvilgiu nejuda. Nedeformuojamos bandinio dalys 2.1 paveiksle yra šviesios, o deformuojamos tamsesnès. Jungties centravimą pagerina ịvorè 6 . Bandymo metu užrašomas grafikas $F=f(\delta)$, kuri perskaičiavus gaunama priklausomybe் $q=f(\delta)$. Čia $F$ ir $q$ yra tempimo jèga ir išilgai išskirstyta vijų poros apkrova (išilginis vijų apkrovos intensyvumas) atitinkamai, kur $q=F / P$ ir $P$ - sriegio žingsnis. Priklausomybès $q=f(\delta)$ grafinis atvaizdas vadinamas vijų poros deformavimo (arba ilinkių) diagrama. Jos schema parodyta 2.2. skyriuje.

Vijų poros M16×2 bandinio detalès parodytos 2.2 paveiksle. Bandomoji smeige turi šešias atskiras vijas. Vijos išdèstytos pakankamai toli viena nuo kitos 
taip, kad bandant vieną iš jų kitos nebūtų pažeistos. Po kiekvieno bandymo smeigè sutrumpinama, o jos naujame gale suformuojams pagalbinis sriegis M14 pagalbinei veržlei ir šalia esantis cilindrinis paviršius centruojančiai ịvorei užmauti. Visos veržlès buvo gaminamos iš vienos paruošos tam, kad jų mechaninių savybių išsibarstymas būtų kuo mažesnis.

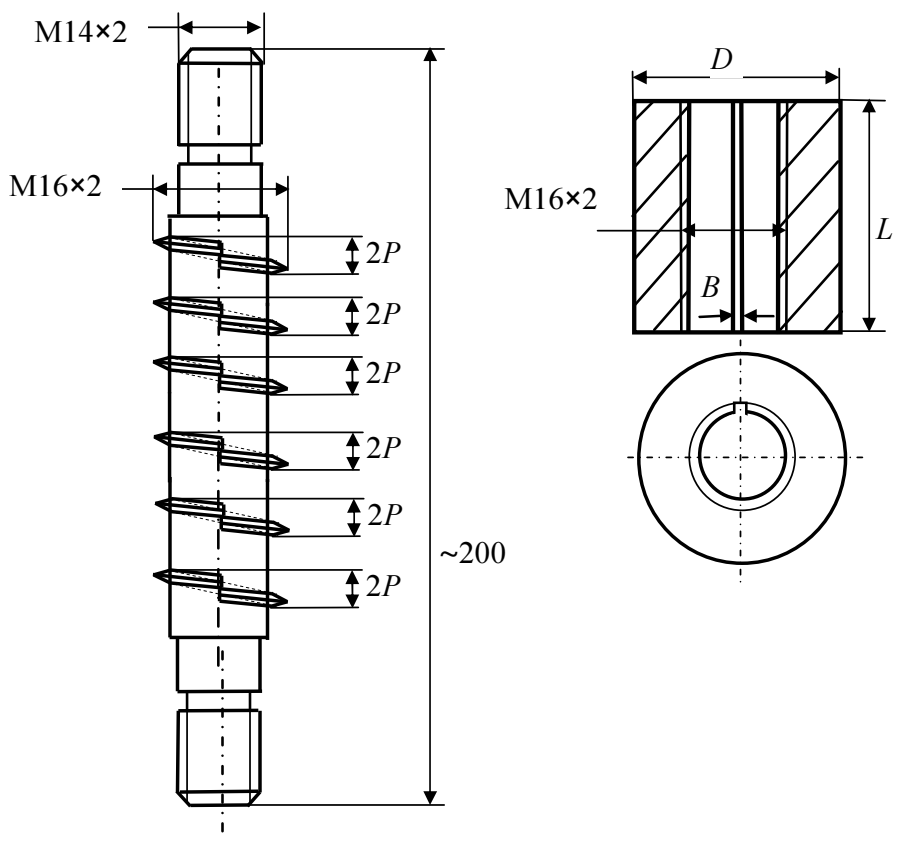

2.2 pav. Specialios srieginès jungties detalès

Fig. 2.2. Details of special threaded connection

Sriegio formavimas smeigeje buvo atliekamas tekinimu M16-6h, o veržlèje M16-6H - sriegiant sriegikliu.

Srieginès jungties elementų ir jų medžiagų stiprumo bei deformavimo rodiklių nustatymui buvo naudojama elektromechaninè bandymo mašina TIRA test 2300 .

2.3 paveiksle parodyta bandymo mašinos schema su specialiaja vijų poros sriegine jungtimi, kuri tempiama su nukrovimais. 


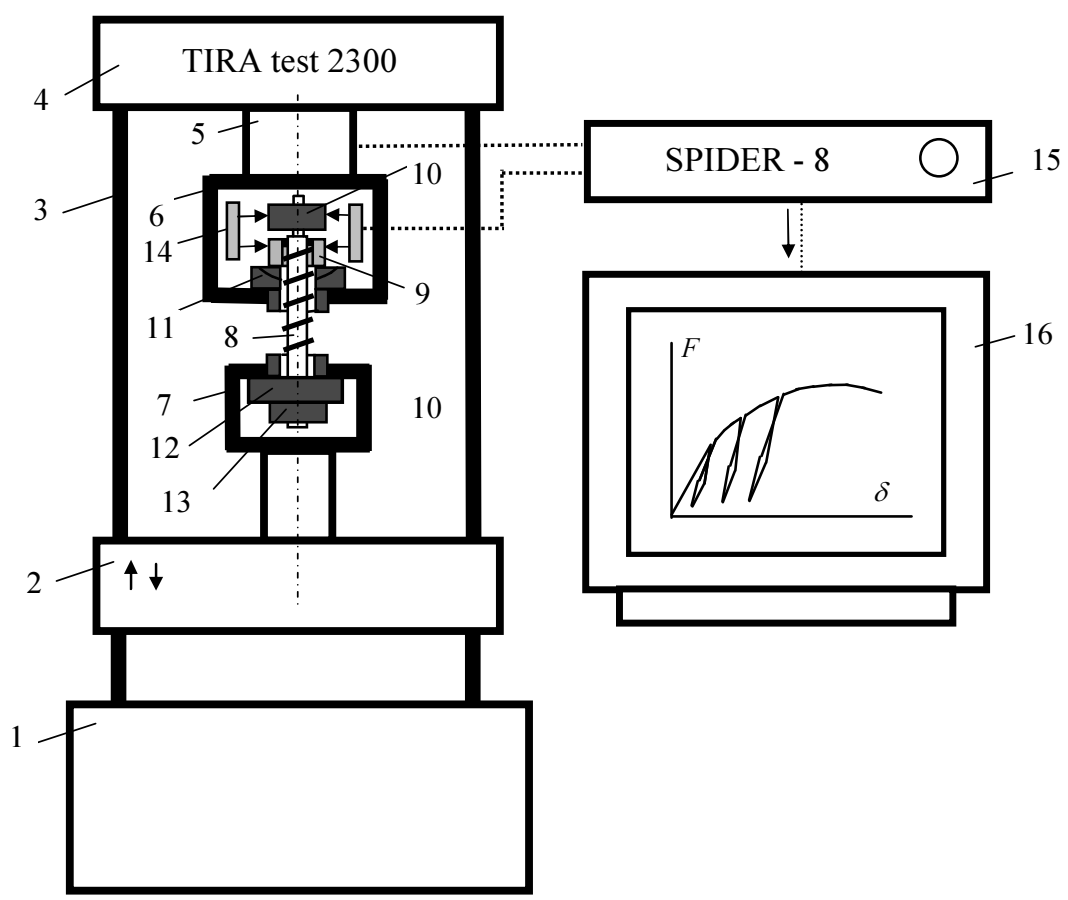

2.3 pav. Tempimo bandymo ịranga

Fig. 2.3. Equipment for tension test

2.3 paveiksle yra parodytos tokios bandymų irangos dalys: 1 - bandymo mašinos korpusas, 2 - paslanki traversa, 3 - kolonos (kreipiančiosios), 4 - stacionari traversa, 5 - dinamometras su indukciniu jutikliu (tamprusis elementas $100 \mathrm{kN}, \pm 1 \%$ tikslumas), 6 - viršutinis griebtas, 7 - apatinis griebtas, 8 - smeigè su atskiromis vijomis, 9 - bandinio veržlè, kurioje yra viena sukibusių vijų pora, 10 - pagalbinè veržlè, sutvirtinta su smeige, 11 - atrama su sfera, 12 atrama, 13 - veržlè, 14 - dvipusis deformometras DD 25 ( $\pm 1 \%$ tikslumas $), 15-$ analoginis skaitmeninis keitiklis SPIDER-8, 16 - monitorius prie kompiuterio su idiegta duomenų registravimo ir apdorojimo programa CATMAN 3.

Pateiktoje bandymo schemoje galima matyti, kad bandymo metu gaunami duomenys yra užrašomi skaitmeninèje formoje, todèl patogūs vykdant jų matematini apdorojimą ir gali būti saugomi kompiuterinèse laikmenose. 


\subsection{Vijų poros ilinkių diagramos aproksimavimas}

Nustatant viju poros deformavimo rodiklius, efektyviausia naudoti tiesėmis aproksimuotą eksperimentinę vijų poros illinkių diagrama, nes tiesiniai ryšiai ženkliai supaprastina matematinio modeliavimo uždavinius.

Reali eksperimentinè vijų poros ilinkių diagrama (2.4 pav.) pradiniame ruože turi tiesini pobūdi, kur vyrauja tampriosios deformacijos. Toliau deformavimo pobūdis akivaizdžiai yra netiesinis. Čia vyrauja plastinès deformacijos.

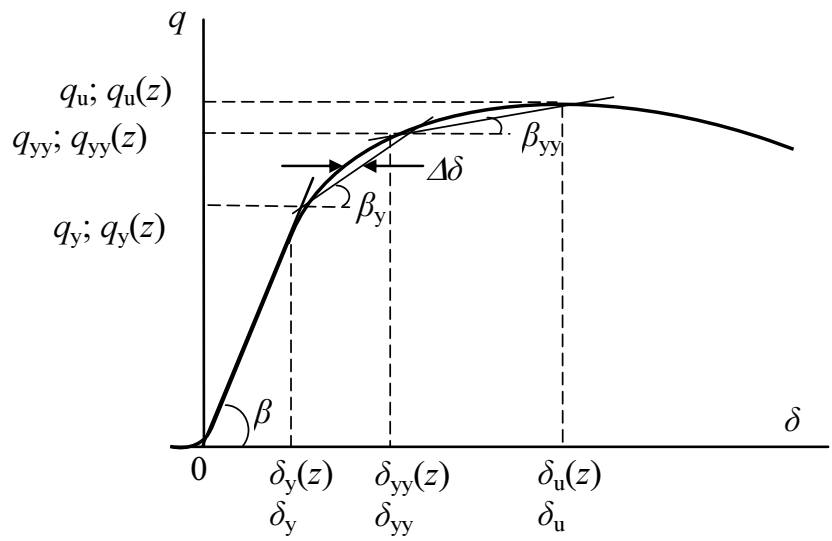

2.4 pav. Sriegio vijų poros deformavimo diagrama

Fig. 2.4. Turn pair deformation diagram

Aproksimavus vijų poros deformavimo diagramą tiesėmis, nustatomi vijų apkrovos intensyvumo rodikliai $q_{y}, q_{y y}, q_{u}$ ir viju poros paslankumai $\gamma_{f}=\operatorname{ctg} \beta$, $\gamma_{p}=\operatorname{ctg} \beta_{y}, \gamma_{p p}=\operatorname{ctg} \beta_{y y}$. Vijuc apkrovos intensyvumo riba $q_{y}$ vadinama takumo jègos intensyvumu. Kita ribinè reikšmè $q_{u}$ vadinama stiprumo jègos intensyvumu. Nepilnu profiliu sukibusių vijų (kurios yra srieginių jungčių kraštuose) deformavimo rodikliai priklauso nuo smeigès ir veržlès vijų sukibties gylio, kuris kinta besikeičiant jų kontakto padèties (realioje jungtyje) išilginei koordinatei $z$. Atitinkamai ir jų deformavimo rodikliai yra priklausomi nuo kontakto padeties (nuo $z$ ): $q_{y}(z), q_{y y}(z), q_{u}(z), \gamma(z), \gamma_{p}(z), \gamma_{p p}(z)$ ir aprašomi atitinkamomis funkcijomis, kurios bus pateiktos kituose skyriuose.

Grafikas (2.5 pav.), kuris vaizduoja nustatytą ir anksčiau literatūroje nenagrinètą vijų poros nukrovimo ir pakartotinio apkrovimo reiškini rodo, kad vijų deformavimas šiuo atveju net pradinejje tiesineje stadijoje akivaizdžiai nèra grižtamasis, o viju paslankumas $\left(\gamma_{r}=\operatorname{ctg} \beta_{r}\right)$ po nukrovimo kartotinai apkraunant ženkliai sumažeja $\left(\gamma_{r}<\gamma_{f}\right)$. 
2.5 a paveiksle yra parodyta diagrama, gauta išbandant su nukrovimais vieną sriegio M16×2 vijų pora, pagamintą iš plieno $25 X 1 M \Phi$.

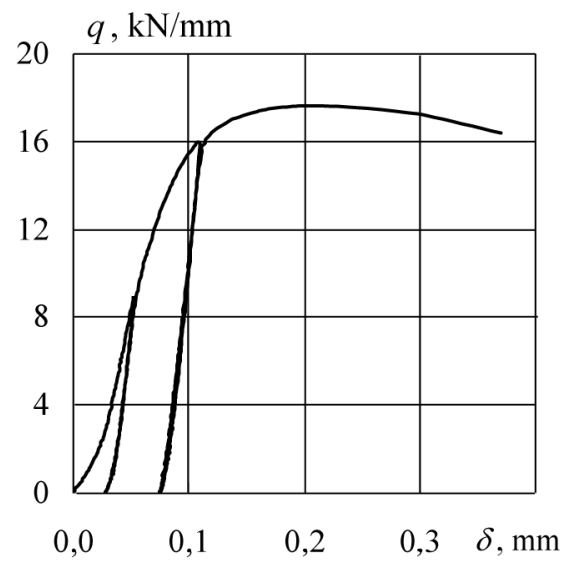

a)

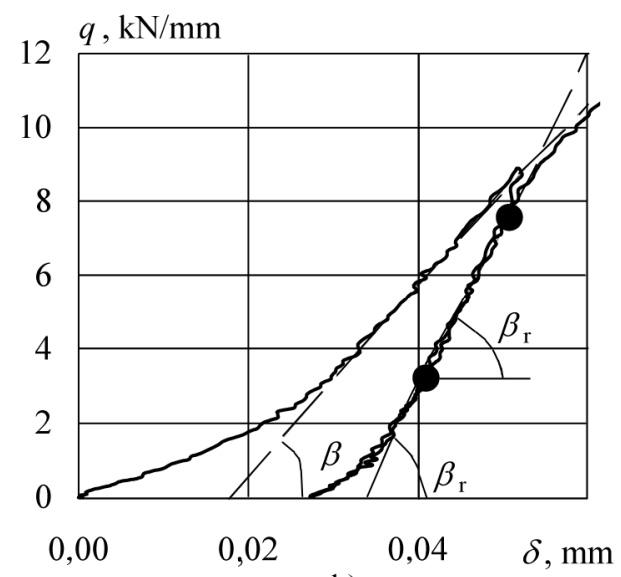

b)

2.5 pav. Sriegio vijų poros M16 $\times 2$ nukrovimai ir kartotiniai apkrovimai

Fig. 2.5. Unloading and realoading of turn pair M16 $\times 2$

2.5 b paveiksle pirmojo nukrovimo ir kartotinio apkrovimo tiesinejje srityje yra parodyti du tamsūs taškai, kurių koordinatès naudojamos kampo $\beta_{r}$ (ir atitinkamo paslankumo $\gamma_{r}$ ) nustatymui. 2.5 paveiksle matyti, kad nukrovimo ir kartotinio apkrovimo procesą vaizduojančios linijos turi gana ilgą praktiškai tiesinę sritị ir yra labai artimos, todèl gali būti aproksimuotos viena tiese.

Srieginiu jungčių tyrimams panaudoti plienai $25 X 1 M \Phi, 45,40 X$, kurie dažnai taikomi atomineje energetikoje. Jų mechaninių savybių rodikliai nustatyti tempiant standartinius glotnius cilindrinius bandinius. Pagrindiniai rodikliai buvo nustatomi pagal standartą LST EN ISO 6892-1:2009.

2.1 lentelè. Medžiagų mechaninių savybių rodikliai

Table 2.1. Mechanical properties of materials

\begin{tabular}{|c|c|c|c|c|c|c|}
\hline \multirow{2}{*}{ Plienas } & $R_{0,02}$ & $R_{0,2}$ & $R_{m}$ & $Z$ & $E$ & $\begin{array}{c}\text { Terminis } \\
\text { apdirbimas }\end{array}$ \\
\cline { 2 - 7 } & $\mathrm{MPa}$ & $\mathrm{MPa}$ & $\mathrm{MPa}$ & $\%$ & $\mathrm{GPa}$ & - \\
\hline $25 X 1 M \Phi$ & 860 & 920 & 1056 & 63,2 & 210 & Grūd.+ atleid. \\
\hline 45 & 348 & 384 & 681 & 43.5 & 210 & Grūd.+ atleid. \\
\hline $40 X$ & 593 & 614 & 825 & 63.8 & 200 & Grūd.+ atleid. \\
\hline
\end{tabular}


Panaudotų medžiagu gamybos technologiją, cheminę sudètį ir fizines savybes reglamentuoja standartai: plienui $25 X 1 M \Phi-G O S T$ 10500-73, plienui $45-$ GOST 1050-70, plienui 40X-GOST 10500-73. Atitinkami šių plienų žymejjimai pagal EN 10083-3 yra: 21CrMoV5-7, C45 ir 41Cr4.

\subsection{Nukrovimo itaka sriegio viju poros paslankumui}

Vienos vijų poros mechaninių savybių rodikliai, kurie nustatyti tempiant be nukrovimų ir panaudoti skaičiavimuose, pateikti 2.2 lenteleje. Duomenys jungtims M52×4 ir M110×6 paimti iš straipsnio (Speičys, Krenevičius 1987).

2.2 lentelè. Tempiamos sriegio vijų poros deformavimo rodikliai

Table 2.2. Deformation properties of turn pair at tension

\begin{tabular}{|c|c|c|c|c|c|}
\hline \multirow{2}{*}{$\begin{array}{l}\text { Sriegine } \\
\text { jungtis }\end{array}$} & \multirow{2}{*}{ Plienas } & $q_{y}$ & $q_{u}$ & $\gamma_{f}$ & $\gamma_{p}$ \\
\hline & & \multicolumn{2}{|c|}{$\mathrm{kN} / \mathrm{mm}$} & \multicolumn{2}{|c|}{$\mathrm{mm} /(\mathrm{kN} / \mathrm{mm})$} \\
\hline M16×2 & $25 X 1 M \Phi$ & 12,5 & 17,5 & $3,8 \times 10^{-3}$ & $1,6 \times 10^{-2}$ \\
\hline M16×1,5 & $25 X 1 M \Phi$ & 13,1 & 18,3 & $4,4 \times 10^{-3}$ & $1,4 \times 10^{-2}$ \\
\hline $\mathrm{M} 16 \times 1$ & $25 X 1 M \Phi$ & 13,5 & 18,8 & $5,1 \times 10^{-3}$ & $1,6 \times 10^{-2}$ \\
\hline $\mathrm{M} 20 \times 2,5$ & $25 X 1 M \Phi$ & 18,3 & 22,8 & $3,8 \times 10^{-3}$ & $1,3 \times 10^{-2}$ \\
\hline $\mathrm{M} 20 \times 1,5$ & $25 X 1 M \Phi$ & 18,9 & 23,5 & $4,2 \times 10^{-3}$ & $1,7 \times 10^{-2}$ \\
\hline $\mathrm{M} 20 \times 2,5$ & 45 & 8,0 & 15,2 & $4,3 \times 10^{-3}$ & $1,7 \times 10^{-2}$ \\
\hline $\mathrm{M} 16 \times 2$ & $25 X 1 M \Phi+40 X$ & 8,2 & 13,8 & $4,1 \times 10^{-3}$ & $1,3 \times 10^{-2}$ \\
\hline M52×4 & $25 X 1 M \Phi$ & 47 & 65,2 & $1,5 \times 10^{-3}$ & $5,8 \times 10^{-3}$ \\
\hline M110×6 & $25 X 1 M \Phi$ & 103 & 131 & $3,3 \times 10^{-3}$ & $8,5 \times 10^{-3}$ \\
\hline
\end{tabular}

Pastaba: kai veržlès ir smeigės medžiaga skirtinga, tai po ženklo + veržlès medžiaga.

Vienos vijų poros mechaninių savybių rodikliai (vidurkiai), nustatyti tempiant su nukrovimais ir kartotiniais apkrovimais penkias kiekvienos rūšies specialias jungtis, pateikti 2.3 lentelèje, o jų diagramos 2.6 paveiksle.

Gautos vijų poru paslankumo reikšmès rodo, kad srieginės jungties nukrovimas visada nèra grį̌tamasis reiškinys - ir kai vyksta pradinejje tiesinejje ir kai vyksta vèlesnejje netiesinèje deformavimo srityse. Kartotinis apkrovimas praktiškai vyksta tuo pačiu deformavimo désningumu kaip ir nukrovimas (tik priešinga kryptimi). Nukrovimas ir kartotinis apkrovimas beveik viso proceso metu vyksta praktiškai pagal tiesini dėsni ir tik esant labai mažoms apkrovoms tampa akivaizdžiai netiesinis. Viju poros paslankumo $\gamma_{r}$ reikšmès, apskaičiuotos pagal tiesinę deformavimo (nukraunant) diagramos dali, yra daugiau kaip 2 kartus didesnès (apytiksliai 2-2,4 karto) už vijų paslankumo $\gamma_{f}$ reikšmes, nustatytas pagal pirmojo apkrovimo tiesinę vijų tempimo diagramos dali. 
2.3 lentelè. Kartotinai apkraunamos vijų poros paslankumo rodikliai

Table 2.3. Pliabilities of turn pair at reapeted loading

\begin{tabular}{|c|c|c|c|c|c|}
\hline \multirow{2}{*}{$\begin{array}{l}\text { Sriegine } \\
\text { jungtis }\end{array}$} & \multirow{2}{*}{ Plienas } & $\gamma_{r}$ & $\gamma_{f} / \gamma_{r}$ & $\gamma_{r}$ & $\gamma_{f} / \gamma_{r}$ \\
\hline & & $\mathrm{mm} /(\mathrm{kN} / \mathrm{mm})$ & - & $\mathrm{mm} /(\mathrm{kN} / \mathrm{mm})$ & - \\
\hline M16×2 & $25 X 1 M \Phi$ & $1,87 \times 10^{-3}$ & 2,13 & $1,84 \times 10^{-3}$ & 2,16 \\
\hline M16 $\times 1,5$ & $25 X 1 M \Phi$ & $1,83 \times 10^{-3}$ & 2,36 & $1,98 \times 10^{-3}$ & 2,18 \\
\hline $\mathrm{M} 16 \times 1$ & $25 X 1 M \Phi$ & $2,45 \times 10^{-3}$ & 2,23 & $1,63 \times 10^{-3}$ & 3,52 \\
\hline $\mathrm{M} 20 \times 2,5$ & $25 X 1 M \Phi$ & $1,58 \times 10^{-3}$ & 2,45 & $1,23 \times 10^{-3}$ & 3,40 \\
\hline $\mathrm{M} 20 \times 1,5$ & $25 X 1 M \Phi$ & $1,86 \times 10^{-3}$ & 2,4 & $1,91 \times 10^{-3}$ & 2,34 \\
\hline $\mathrm{M} 20 \times 2,5$ & 45 & $2,30 \times 10^{-3}$ & 2,11 & $2,25 \times 10^{-3}$ & 2,03 \\
\hline & & $\begin{array}{l}\text { pirmas nukr } \\
\text { tampriojpje }\end{array}$ & $\begin{array}{l}\text { imas } \\
\text { ityje }\end{array}$ & $\begin{array}{l}\text { antras nukrov } \\
\text { riai plastine }\end{array}$ & $\begin{array}{l}\text { tamp } \\
\text { rityje }\end{array}$ \\
\hline
\end{tabular}
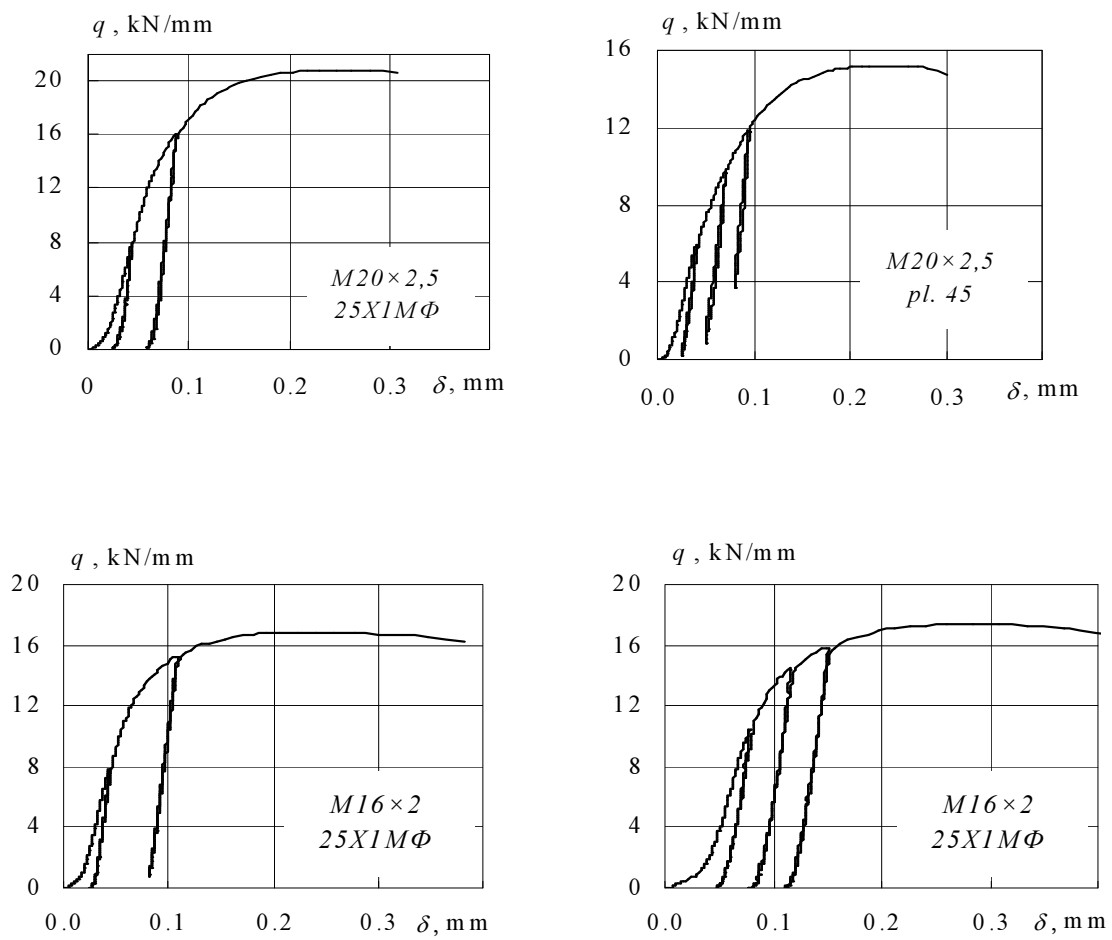

2.6 pav. Sriegio vijų poru M20 ir M16 nukrovimai ir kartotiniai apkrovimai

Fig. 2.6. Unloading and realoading of turn pair M20 
Anksčiau srieginių jungčių mechanikos tyrèjai analitiškai nustatinejjo tik vijų paslankumo $\gamma_{f}$ reikšmes ir nustatinèjo jas remdamiesi tik tamprumo teorijos postulatais. Bet atlikti viju porų tempimo bandymai su nukrovimais rodo, kad modeliuojant vijų deformavima, būtina ịvertinti ir plastinių deformacijų itaka, atsirandančią vijų kontakto paviršiuose. Kitą vertus, pirmojo apkrovimo metu iš pradžių vijų poros deformavimas yra tiesinis ir galima teigti, kad šioje deformavimo stadijoje tamprusis deformavimas dominuoja. Šioje disertacijoje pagal literatūroje nusistovejjusią tradiciją pradinę tiesinę vijų deformavimo stadiją autorius toliau vadina tampriaja deformavimo stadija.

2.4 lenteleje ir A priede A.1 lenteleje pateikti 12 viju poru M16×2 paslankumų duomenys. Vertinant paslankumu $\gamma_{f}$ ir $\gamma_{r}$ išsibarstymą galima pasakyti, kad jis priimtinas, nes pagal dvi viju paslankumo $\gamma_{f}$ reikšmes, kurios skyrèsi $10 \%$, apskaičiuotos maksimalios tampriai deformuotų vijų apkrovos $q_{\max }$ realioje tempiamoje jungtyje skiriasi 3,3\%. Esant $\gamma_{f}$ nuokrypiui $3 D$, viju M16 $\times 2$ apkrovos $q_{\max }$ realioje tempiamoje jungtyje nuo vidutinès reikšmès $q_{\max , v i d}$ skirtųsi apie $2,4 \%$.

2.4 lentelè. Sriegio vijų poros M16 $\times 2$ deformavimo statistiniai rodikliai

Table 2.4. Statistical properties of deformation of turn pair M16 $\times 2$

\begin{tabular}{|c|c|c|c|c|c|}
\hline Rodiklis & $\begin{array}{c}\text { Band. } \\
\text { skaič. }\end{array}$ & Vidurkis & Dispersija & $\begin{array}{c}\text { Standartinis } \\
\text { nuokrypis }\end{array}$ & $\begin{array}{c}\text { Variacijos } \\
\text { koeficientas }\end{array}$ \\
\hline$J$ & $n$ & $J^{*}=\frac{\Sigma J_{i}}{n}$ & $D^{2}=\frac{\sum\left(J_{i}-J^{*}\right)^{2}}{n-1}$ & $D$ & $V=\frac{D}{J^{*}} 100 \%$ \\
\hline$\gamma$ & 12 & $3,97 \times 10^{-3}$ & $9,74 \times 10^{-9}$ & $9,87 \times 10^{-5}$ & 2,5 \\
\hline$\gamma_{r}$ & 12 & $1,87 \times 10^{-3}$ & $1,68 \times 10^{-9}$ & $4,10 \times 10^{-5}$ & 2,2 \\
\hline$\gamma / \gamma_{r}$ & 12 & 2,13 & 0,0061 & 0,078 & 3,7 \\
\hline
\end{tabular}

\subsection{Antrojo skyriaus išvados}

1. Eksperimentinès vijų porų paslankumo $\gamma_{r}$ reikšmès, nustatytos jas nukraunant ir kartotinai apkraunant, yra daugiau kaip 2 kartus didesnès (apytiksliai 2-2,4 karto) už vijų paslankumo $\gamma_{f}$ reikšmes, nustatytas pagal pirmojo apkrovimo tiesinę vijų tempimo diagramos dali.

2. Eksperimentinès vijų porų paslankumo $\gamma_{r}$ reikšmès, nustatytos jas nukraunant ir kartotinai apkraunant plastinio deformavimo srityje, praktiškai nesiskiria nuo atitinkamų reikšmių, nustatytu pagal pirmojo apkrovimo tiesinę vijų tempimo diagramos dali. 



\section{Lenkiamų srieginių jungčių tamprieji modeliai}

Šiame skyriuje aprašoma tiriamoji srieginė jungtis: jos apkrovos ir įrąžos, nuo kurių didumo priklauso vietinių itempių, atsirandačiu smeigès vijų i̇dubose, didumas. Nurodyti srieginès jungties elementų deformatyvumo ypatumai ir išryškinti jos diskretizavimo principai. Sudaryta lenkiamos srieginès jungties elementų deformavimo ir poslinkių schema ir užrašyta šių poslinkių darnos integraline lygtis. Pateiktos vijų illinkių diferencialinès lygtys ir jų sprendiniai, kurių visuma sudaro necentriškai tempiamos srieginès jungties trijų ruožų modelio turini. Palyginti skaičiavimo rezultatai, gauti, naudojant analitinius sprendinius ir Rungès - Kuto metodą. Analizuojamas smeigès ir veržlès iražuc, vijų apkrovų ir vietinių itempių pasiskirstymas ịveržtose ir lenkiamose srieginèse jungtyse. Skyriuje yra parodomos analitinio modelio galimybès atspindèti konstrukcinių faktorių itaką. Pateiktas daugiaruožis apkrovos pasiskirstymo sriegyje modelis, skirtas po įveržimo lenkiamos jungties atvejams. Šio skyriaus medžiaga buvo paskelbta autoriaus straipsniuose (Krenevičius, Juchnevičius 2009a, Juchnevičius, et al. 2010a, 2010b, Juchnevičius, Krenevičius, 2011b, 2011c). 


\subsection{Lenkiamos srieginès jungties trijų ruožų modelis}

\subsubsection{Srieginès jungties deformavimo sritis}

Sudarytame modelyje dèl išorinių apkrovų smeigès šerdis ir veržlès sienelè deformuojasi tik tampraus deformavimo srityje, o sukibusių vijų poros poslinkiai yra tiesiniai, nes jų kitimą lemia dominuojančios tampriosios vijų deformacijos.

Laikoma, kad srieginès jungties deformacijos, atsirandančios dèl ašinių ir lenkimo apkrovų, tarpusavio įtaka - nežymi. Todèl, modeliuojant srieginę jungti, ašinių ir lenkimo apkrovų poveikiai matematinèmis formulèmis nagrinèjami atskirai, o gautų rezultatų suma yra šių apkrovų bendro poveikio išraiška.

3.1. skyriaus tyrimo objektas yra sriegine jungtis: smeigè su gniuždoma veržle (arba varžtas su gniuždoma veržle), kuri patiria necentrini tempimą. Necentrinis tempimas gali pasireikšti jau įveržiant jungti arba ją eksploatuojant po ašinio ivveržimo. Ašinè apkrova yra dominuojanti, todèl veikiant lenkimui, abiejose jungties pusėse pusvijų apkrova turi vienodą pobūdi - abiejose pusèse jos apkraunamos arba nukraunamos.

\subsubsection{Išorinès ir vidinès apkrovos}

Bendru atveju srieginę jungti veikia išorinė ašinè jẻga $F_{t}$ ir išorinis lenkimo momentas $M_{f}$ (3.1 a pav.).

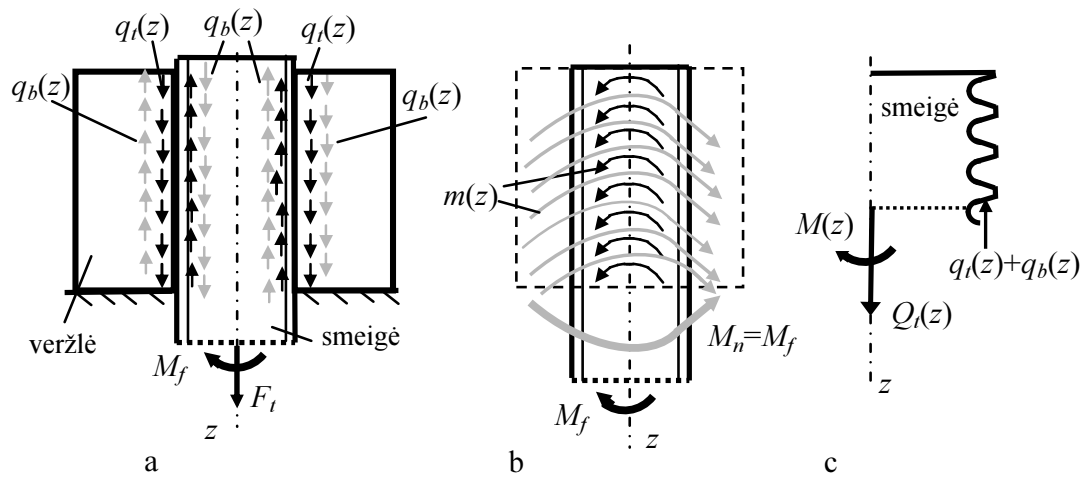

3.1 pav. Srieginės jungties išorinės apkrovos: tempimas ir lenkimas (a), lenkimas (b), apkrovos lemiančios vietinių ịtempių atsiradimą smeigès sriegyje (c)

Fig. 3.1. External loads on threaded connection: tension and bending (a), bending (b), loads caused local stresses in stud's thread (c) 
Ašinės jègos $F_{t}$ ir lenkimo momento $M_{f}$ poveikis tenka smeigès šerdžiai ir sukibusias srieginès jungties vijas priverčia deformuotis. Vijose atsiradusios reakcijos jègos schematizuojamos atitinkamomis išskirstytomis išilginèmis apkrovomis $q_{t}(z)$ ir $q_{b}(z)$, apkrovomis, išsidèsčiusiomis ant vijų sraigtinès linijos atitinkančios vidurini sriegio skersmeni $2 R$. Jų išsidèstymas smeigès sriegyje parodytas 3.1 a ir 3.2 paveiksluose. 3.2 Paveiksle parodyta, kad išskirstytos apkrovos $q_{b}(z)$, atsiradusios dèl lenkimo, abiejose pusèse nuo skerspjūvio neutraliosios linijos $N L$ ( $N L$, vertinant tik lenkima) veikia priešinga kryptimi ir yra nutolusios nuo neutraliosios linijos atstumu $R \sin (c z)$, kur $c=2 \pi / P, P-$ sriegio žingsnis.

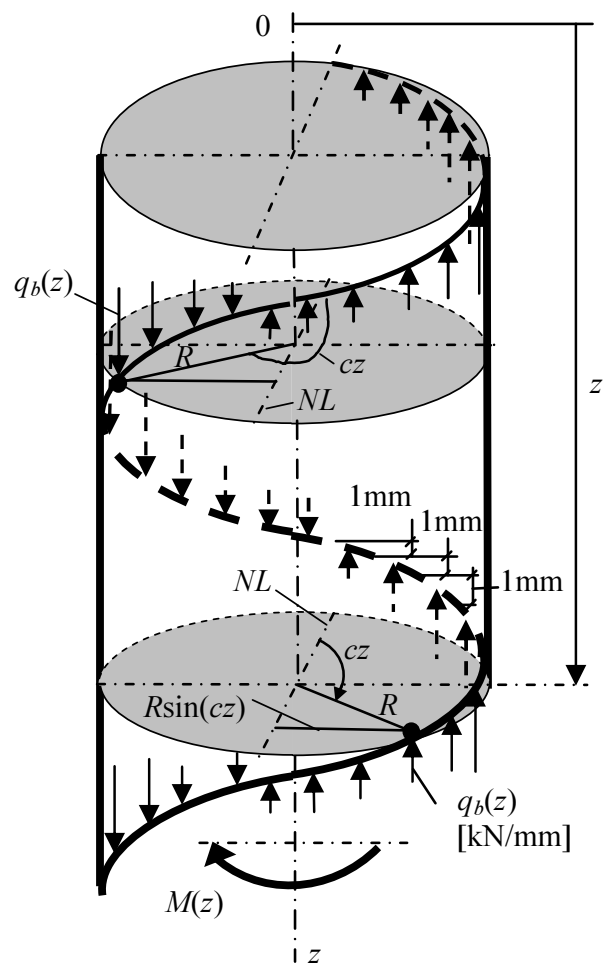

3.2 pav. Smeigès vijos apkrova $q_{b}(z)$ ant sraigtinès linijos

Fig. 3.2. Turn loads $q_{b}(z)$ on stud's thread helix

Išskirstytos apkrovos $q_{b}(z)$, turèdamos peti $R \sin (c z)$, smeigès skerspjūvyje $z$ (3.1 b ir 3.2 pav.) sukelia išorinį išskirstytą lenkimo momentą $m(z)$ ir atitinkamą vidinị lenkimo momentą (ịrąža) $M(z)$ : 


$$
\begin{gathered}
m(z)=q_{b}(z) R \sin (c z), \\
M(z)=\int_{0}^{z} m(z) d z .
\end{gathered}
$$

Sukibusios smeigès ir veržlès vijos besideformuodamos vienodai spaudžia viena kitą priešingomis kryptimis. Todèl, kaip ir smeigeje, tokio pat didumo išskirstytos apkrovos $q_{t}(z)$ ir $q_{b}(z)$ veikia ir veržlès vijas tik priešingomis kryptimis. Išskirstyta vijų apkrova $q_{b}(z)$, veikianti veržlès vijas, sukelia išskirstytą lenkimo momentą $m(z)$ ir veržlèje, kuris yra priešingas tokiam pat momentui, veikiančiam smeigeje. $3.1 \mathrm{~b}$ paveiksle išskirstytas lenkimo momentas $m(z)$, veikiantis veržlę, pavaizduotas šviesiais vektoriais. Su šiuo išskirstytu momentu pusiausvyrą sudaro reakcijos momentas $M_{n}=M_{f}$, atsirandantis veržlès ir atramos kontakto plokštumoje.

3.1 c paveiksle parodytos apkrovos, dèl kurių nagrinèjamame skerspjūvyje smeigès vijos įduboje atsiranda vietinių itempių, lemiančių nuovarginio plyšio atsiradimą. Tai smeigès skerspjūvyje $z$ jos šerdi veikiančios apkrovos: ašinè ịraža $Q_{t}(z)$ ir vidinis lenkimo momentas $M(z)$, bei smeigès viją veikianti suminé apkrova $q_{t}(z)+q_{b}(z)$.

Ašinèms ivveržimo jẻgoms $q_{t}(z)$ ir $Q_{t}(z)$ skaičiuoti disertacijoje yra panaudota Birgerio metodika (Birger, Josilevič 1990), patobulinta VGTU stiprumo mechanikos laboratorijoje (Selivonec, Krenevičius 2004).

\subsubsection{Srieginès jungties diskretizavimas}

Sudarant lenkiamos srieginès jungies modelị turi būti ịvertinti jos geometriniai ypatumai.

Žinoma, kad formuojant veržlès sriegi, abiejuose jos galuose susiformuoja vijų kuriu aukštis ir storis mažeja artejjant joms prie veržlès krašto. Dèl šios priežasties smeigès ir veržlès vijos srieginès jungties galuose yra sukibusios ne visu profiliu. Diskretiniame srieginès jungties modelyje jos sudaro du atskirus ruožus $H_{1}$ ir $H_{3}$ (3.3 a pav.), kurių ilgiai yra lygūs sriegio žingsniui $P$. Atitinkamas vijų poras toliau vadinsime jungties įvijomis. Viduriniame ruože $H_{2}$ smeigès ir veržlès vijos sukibusios visu profiliu. Visą jungties ilgi sudaro suma $H=H_{1}+H_{2}+H_{3}$.

Kitas lenkiamos jungties ypatumas yra tas, kad vijų sraigtinès linijos išsidèstymo padéčių atžvilgiu lenkimo plokštumos gali būti be galo daug. Tą svarbu ivertinti nagrinèjant vijų apkrovas pavojingoje jungties zonoje - ruože $H_{3}$ ir ruožų $H_{3}$ ir $H_{2}$ sandūros aplinkoje. 3.2 ir 3.3 b paveiksluose parodyta, kad apkrovos $q_{b}(z)$ pridèties taško atstumas $R \sin (c z)$ iki neutraliosios linijos yra skirtingas, nes priklauso nuo sraigtinès linijos ir lenkimo plokštumos tarpusavio padèties. No- 
rima sinusoidès $R \sin (c z)$ padètis nustatoma naudojant (čia vadinama) sinusoidès pradinès fazès ilgi $z_{f}$, kuris užduoda jungties skerspjūvių išilginès koordinatès $z_{i}$ atskaitos pradžią.

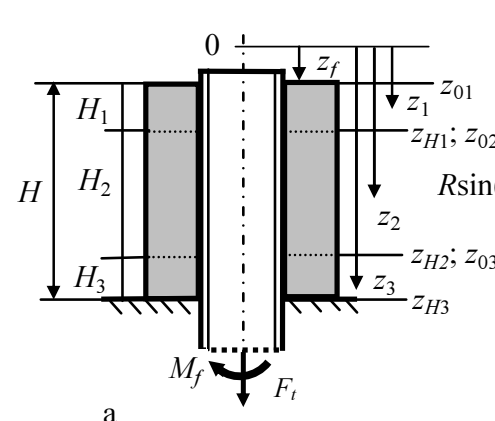

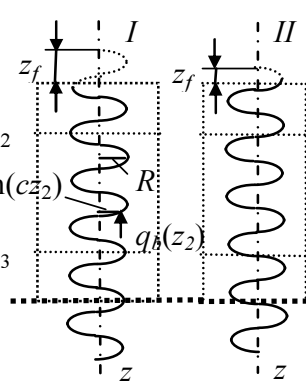

b

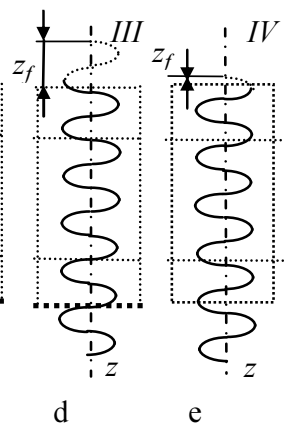

3.3 pav. Srieginès jungties diskretizavimas (a) ir sraigtinès vijų linijos padètys (b, c, d, e)

Fig. 3.3. Segments of threaded connection (a) and particular helix positions (b, c, d, e)

Koordinačių sistemoje, kurios pradžia nutolusi nuo laisvojo veržlès galo atstumu $z_{f}$, bet kurio jungties skerspjūvio $z_{i}$, esančio ruože $i$, realus nuotolis nuo veržlès laisvojo galinio paviršiaus visada yra lygus $z_{l}-z_{f}$. Šioje koordinačiu sistemoje nagrinejjamo ruožo pradinio ir galinio skerspjūvio koordinatès atitinkamai yra $z_{0 i}$ ir $z_{H i}(3.3$ pav.).

3.3 paveiksle parodytos keturios ypatingos vijų sraigtinès linijos padètys $I$, $I I, I I I, I V$, kurios suponuoja ir atitinkamas smeigès skerspjūvio $z_{H 2}$ kampines padètis lenkimo plokštumos atžvilgiu. Jos parodytos 3.4 paveiksle.

Jungties skerspjūvyje $z_{H 2}$ prasideda smeigès ir veržlès vijų sukibimas visu profiliu. Lenkimo atveju smeigès skerspjūvi $z_{H 2}$ reikia nagrinèti kaip vieną iš galimų pavojingujų nes žinoma, esant ašiniam tempimui šiame skerspjūvyje smeigès vijos įduboje atsiranda didžiausių vietinių ịtempių. Kai smeigè yra padètyse $I$ ir $I V$, šiame skerspjūvyje veikianti vijų apkrova $q_{b}\left(z_{H 2}\right)$ turi didžiausią peti atitinkamai tempiamoje ir gniuždomoje smeigès pusėse - didžiausią atstumą iki neutraliosios linijos $R \sin \left(c z_{H 2}\right)= \pm R$. (Terminas, ,gniuždomoje smeigès pusèje“ čia pavartotas sąlyginai taip, kaip būtų vartojamas, jeigu smeige būtų tik lenkiama). Tuomet momentas $m\left(z_{H 2}\right)$ čia igauna didelę skaitinę reikšmę. Kai smeigé yra padetyse $I I$ ir $I I I$, jèga $q_{b}\left(z_{H 2}\right)$ neturi peties, nes $R \sin \left(c z_{H 2}\right)=0$. Siais atvejais $m\left(z_{H 2}\right)=0$. 


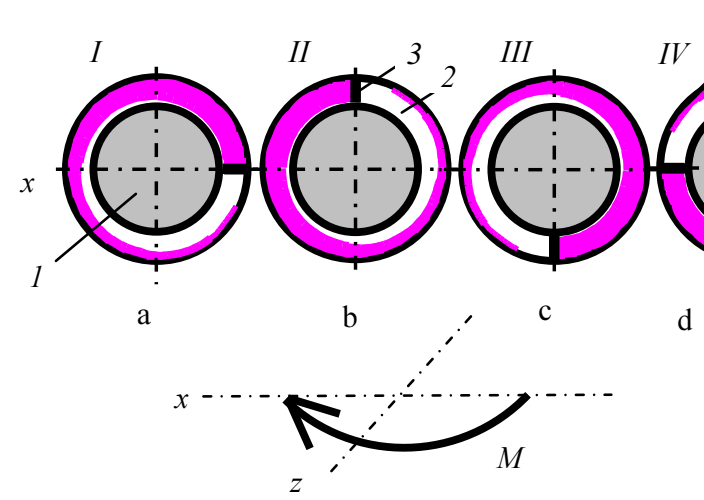

3.4 pav. Smeigès skerspjūvio $z_{H 2}$ ypatingosios padètys $I, I I, I I I, I V(\mathrm{a}, \mathrm{b}, \mathrm{c}, \mathrm{d})$ : smeigès šerdis (1), smeigès vija (2), vijos sankirta su skerspjūvio $z_{H 2}$ plokštuma (3), ne viso profilio vijų kontakto ruože $H_{3}$ projekcija skerspjūvio $z_{H 2}$ plokštumoje (4)

Fig. 3.4. Particular positions $I, I I, I I I, I V(\mathrm{a}, \mathrm{b}, \mathrm{c}, \mathrm{d})$ of the stud's cross section $z_{H 2}$ : stud's core (1), stud's turn (2), intersection of the stud's turn with the plane of the cross section $z_{H 2}(3)$, projection of turns contact area in runout $H_{3}$ to the plane at $z_{H 2}(4)$

\subsubsection{Lenkiamos jungties sriegio vijų ilinkiai}

Srieginès jungties detalių - smeigès ir veržlès - jungtị realizuoja sukibusios vijos.

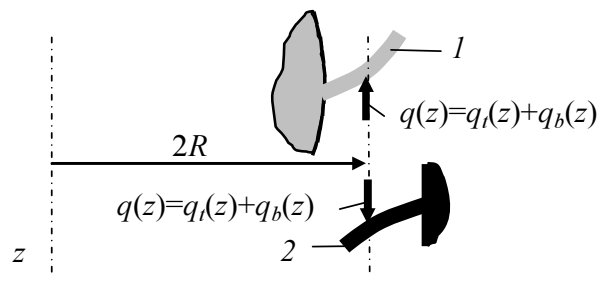

3.5 pav. Sriegio vijų apkrova: smeigès vija (1), veržlès vija (2)

Fig. 3.5. Loads on thread turns: stud's turn (1), nut's turn (2)

Sukibusios vijos besideformuodamos vienodai spaudžia viena kitą priešingomis kryptimis. Laikome, kad lenkiamoje jungtyje, kaip ir tempiamoje ašine kryptimi, vijų apkrova veikia ta pačia - ašine kryptimi. Jègos, deformuojančios smeigès ir vežlès vijas yra vienodo didumo ir priešingos krypties (3.5 pav.). Kaip aprašyta 3.1.2. skyrelyje, šios jègos schematizuojamos išilginemis išskirstytomis vijų apkrovomis $q_{t}(z)$ ir $q_{b}(z)$. Taigi visa apkrova, tenkanti vijoms yra $q(z)=q_{t}(z)+q_{b}(z)$. 
Vijos illinkiu lenkiamoje jungtyje, kaip ir tempiamos jungties atveju, vadinsime ašinès krypties poslinkị, kuri igauna vijų kontakto taškas, esantis ties viduriniuoju sriegio skersmeniu $2 R$. Kadangi $q_{b}(z)$ veikia ta pačia kryptimi, kaip ir $q_{t}(z)$, tai galima laikyti, kad ir viju poros deformavimas, atsirandantis dèl lenkimo t. y. dèl $q_{b}(z)$, vyksta pagal tą pati désninguma, kaip ir tempiamos jungties atveju. Žinoma, kad viju poros deformavimą - ilinkio didumą - lemia vijų poros paslankumas $\chi(z)$ - vijų poros deformavimo charakteristika.

Vijų pora iki tam tikros ribos deformuojasi tiesiškai. Todèl viju poros įlinkis aprašomas tiesine lygtimi:

$$
\delta(z)=\gamma(z) q(z)=\gamma(z)\left[q_{t}(z)+q_{b}(z)\right] .
$$

Išraiškoje (3.3) galima išskirti dvi vijų ilinkio dedamąsias. Vijų poros įlinkio dedamoji, atsirandanti dèl jungtị veikiančios ašinès jègos (ịveržimo), yra:

$$
\delta_{t}(z)=\gamma(z) q_{t}(z) .
$$

Vijų poros įlinkio dedamoji, atsirandanti dèl jungties lenkimo, yra:

$$
\delta_{b}(z)=\gamma(z) q_{b}(z) .
$$

Poslinkiu schema pateikta 3.6 paveiksle rodo, kokia darna lieka tarp smeigès šerdies ir veržlès sienelès skerspjūvių kampinių poslinkių bei vijų ịlinkių deformuotoje jungtyje (vaizdui supaprastinti 3.6 paveiksle parodytos žiedinès vijos).

Anksčiau ašine jèga tempiamų jungčių atvejams sudarytuose analitiniuose modeliuose smeigès vijos arba veržlès vijos ịlinkiu (linijiniu poslinkiu) yra laikomas kelias, kurį nueina vidurinysis vijos taškas (taškai $g$ ir $p 3.6$ a paveiksle) ašine kryptimi. Jungtyje, kurią veikia tik ašinè išorinè jèga, smeigès ir veržlès ¡linkiai $\delta_{t s}$ ir $\delta_{t n}$ yra parodyti $3.6 \mathrm{~b}$ paveiksle. Tai atstumas tarp tašku $g$ ir $g^{*}$ smeigès vijai ir atstumas tarp tašku $g$ ir $g^{* *}$ veržlès vijai. (Kitoje jungties puséje viskas analogiška taško $p$ atžvilgiu).

Tempiamų jungčių modeliuose, taškų $g^{*}$ ir $g^{* *}$ (ir taškų $p^{*}$ ir $p^{* *}$ ) padètis nustatoma pagal įsivaizduojamaji jungties būvị. Šio būvio smeigès ir veržlès kūnai yra deformuoti, o vijos nedeformuotos, neilinkusios. Tuomet, taikant plokščiujų pjūvių hipotezę laikoma, kad po smeigès deformavimo isivaizduojamoji smeigès vijos viduriniojo taško padètis $g^{*}$ lieka pasislinkusioje smeigès šerdies plokštumoje $s^{*}$. Po veržlès deformavimo isivaizduojamoji vijos viduriniojo taško padètis $g^{* *}$ lieka pasislinkusioje veržlès sienelès plokštumoje $s^{* *}$. Tuomet viju poros ịlinkis $\delta_{t}=\delta_{t s}+\delta_{t n}$ yra lygus atstumui tarp smeigès ir veržlès skerspjūvių, dèl deformacijų pasislinkusių ašine kryptimi ir atsiradusių plokštumose $s^{*}$ ir $s^{* *}$. 

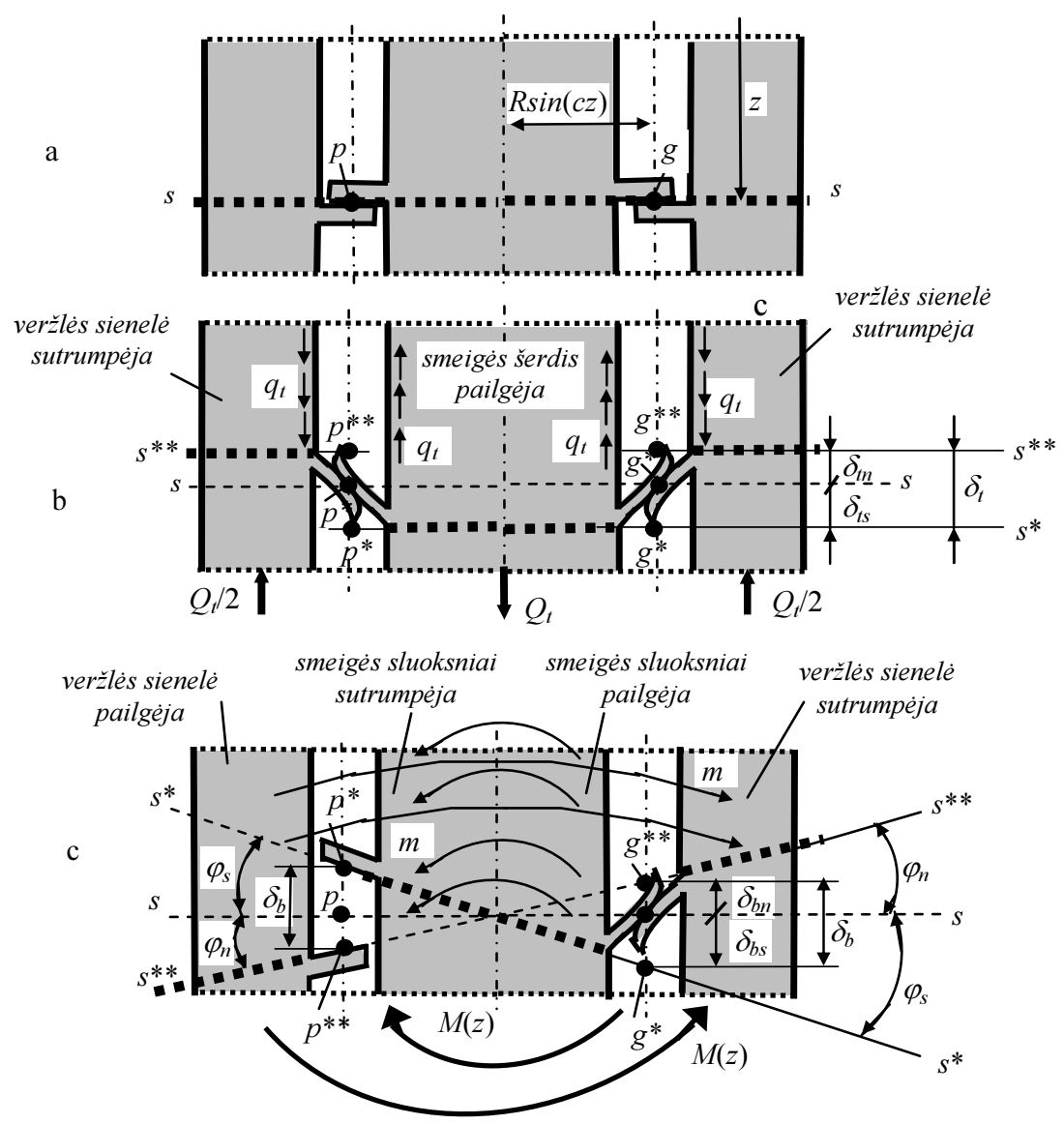

3.6 pav. Sriegio vijų įlinkiai: neapkrauta vijų pora (a), vijų poros įlinkiai tempiamoje jungtyje (b), viju poros įlinkiai, atsiradę dèl jungties lenkimo (c)

Fig. 3.6. Deflections of the thread turns: no loaded turns pair (a), deflection of turns pair at axial tension (b), deflection of turns pair due to bending (c)

Šiame darbe, taikant plokščiujų pjūvių hipotezę lenkiamai jungčiai, laikoma, kad po smeigès deformavimo lenkimu isivaizduojamoji smeigès vijos viduriniojo taško padètis $g^{*}$ lieka kampu $\varphi_{s}$ pasisukusioje smeigès šerdies plokštumoje $s^{*}$ (3.6 c pav.). Po veržlès deformavimo lenkimu pradinè isivaizduojamoji veržlès vijos viduriniojo taško padètis $g^{* *}$ lieka kampu $\varphi_{n}$ pasisukusioje veržlès sienelès plokštumoje $s^{* *}$. Tuomet vijų ilinkiai $\delta_{b s}$ ir $\delta_{b n}$, parodyti 3.6 c paveiksle, su atitinkamais smeigès ir veržlès skerspjūviu posūkio kampais $\varphi_{s}$ ir $\varphi_{n}$, atsiradusiais ties koordinate $z$, gali būti susieti šiomis lygtimis: 


$$
\begin{aligned}
& \varphi_{s}(z) \approx \tan \varphi_{s}(z)=\frac{\delta_{b s}(z)}{R \sin (c z)}, \\
& \varphi_{n}(z) \approx \tan \varphi_{n}(z)=\frac{\delta_{b n}(z)}{R \sin (c z)} .
\end{aligned}
$$

3.6 c paveiksle galima pastebèti, kad, jungti veikiant tik lenkimo momentu, smeigès ir veržlès skerspjūviai pasisuka priešingomis kryptimis. Todèl toje puseje nuo $N L$, kurioje smeigès sluoksniai ilgejja, didejjant skerspjūviu pasisukimo kampams, kontaktą patiriančios smeigès ir veržlès vijos vis daugiau spaudžia viena kitą. Todèl vijų poros įlinkis $\delta_{b}=\delta_{b s}+\delta_{b n}$ čia dideja. Kitoje pusèje nuo $N L$ smeigès ir veržlès vijos viena nuo kitos tolsta. Iveržtos jungties atveju, vijoms tolstant vienai nuo kitos, ịveržimo metu igytas vijų poros įlinkis mažeja.

3.7 a paveiksle parodyta, kad srieginès jungties viduriniame ruože $\mathrm{H}_{2}$ vijos yra sukibusios visu profiliu. Jų sukibimo gylis $t_{f}$ visame šio ruožo ilgyje nesikeičia. Todèl nesikeičia ir vijų paslankumo reikšmè (3.7 b pav.):

$$
\gamma\left(z_{2}\right)=\gamma_{f}=\text { const }
$$

Kraštiniuose jungties ruožuose $H_{1}$ ir $H_{3}$ vijų sukibimo gylis $t_{p}(z)$ mažèja nuo $t_{f}$ reikšmès iki nulio, sekant ji veržlès galinių plokštumų kryptimi. Todèl šiuose ruožuose atitinkamai kinta ir vijų paslankumai $\chi\left(z_{1}\right)$ ir $\chi\left(z_{3}\right)$.

Paslankumo kitimo ruožuose $H_{1}$ ir $H_{3}$ aprašymui nagrinèjamame modelyje yra panaudota funkcija, aproksimuojanti visu ir ne visu profiliu sukibusių viju poros deformavimo eksperimentinius duomenis (Selivonec, Krenevičius 2004). Abiem ruožams, kai $i=1$ arba $i=3$, šios funkcijos pavidalas yra vienodas:

$$
\gamma\left(z_{i}\right)=V_{i} e^{u_{i} z_{i}}
$$

Koeficientai $V_{i}$ ir $u_{i}$ yra nustatomi, parašius nagrinèjamajam ruožui dvi lygtis (atskirai, kai $i=1$ arba $i=3$ ), kurios gaunamos i formulę (3.9) ịstačius dvi žinomas paslankumo reikšmes. Tai vijų paslankumo reikšmės, kurias vijų poros turi viename ruožo krašte ir to paties ruožo viduryje. Viename ruožo krašte vijos sukibusios visu profiliu, todèl čia $\chi\left(z_{H 1}\right)=\gamma_{f}$ ir $\chi\left(z_{03}\right)=\gamma_{f}$ (B priedas). Eksperimentiniai duomenys rodo, kad jungties kraštinių ruožų viduryje paslankumo reikšmė yra 1,67 karto didesnè už $\gamma_{f}$ reikšmę, nustatytą visu profiliu sukibusių vijų porai. Tuomet $\chi\left(z_{H 1}-P / 2\right)=1,67 \gamma_{f}$ ir $\chi\left(z_{03}+P / 2\right)=1,67 \gamma_{f}$.

3.7 a paveiksle parodyta, kad viju įlinkiai padidejja ir igauna dydi $\delta_{t}(z)+\delta_{b}(z)$ toje pusèje, kur dèl lenkimo smeigès šerdies sluoksniai pailgèja. Kitoje pusèje nuo neutraliosios plokštumos, ivveržimo metu igytą vijų ilinkio didumą $\delta_{t}(z)$, lenkimas sumažina iki $\delta_{t}(z)-\delta_{b}(z)$. 


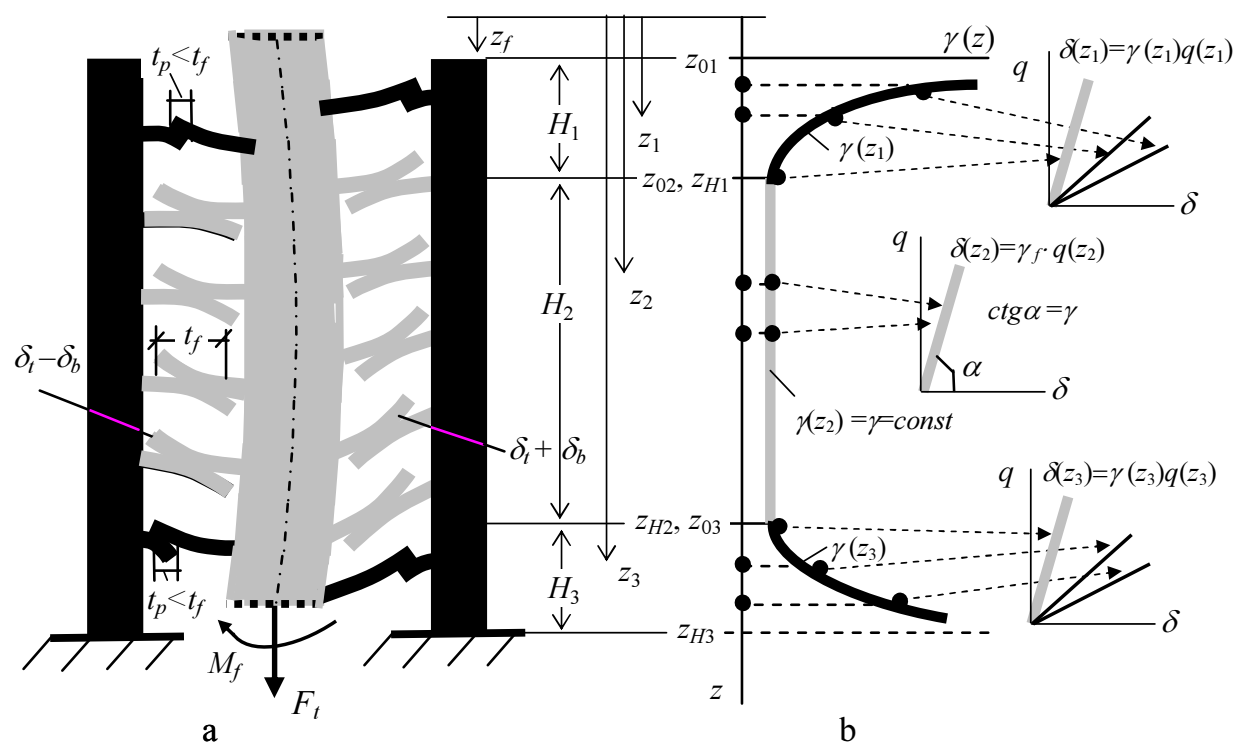

3.7 pav. Sriegio vijų įlinkiai (a), vijų poros paslankumai (b)

Fig. 3.7. Deflections of turns (a), pliabilities of turn pairs (b)

Realiai ašinę vidinę jègą $Q(z)$, veikiančią smeigès skerspjūvyje $z$, sudaro dvi dedamosios - viena $Q_{t}(z)$ atsiranda dèl ịveržimo, o kita $Q_{b}(z)$ atsiranda dèl lenkimo

$$
Q(z)=Q_{t}(z)+Q_{b}(z)=\int_{0}^{z} q_{t}(z) d z+\int_{0}^{z} q_{b}(z) d z .
$$

Iš lygties (3.10) matyti, kad jèga $Q_{b}(z)$ daro poveiki įveržimui, tačiau labai nežymų. Toliau pateikti skaičiavimai parode, kad jos kryptis keičiasi, besikeičiant smeigès ilgio koordinatei $z$ kas pusę sriegio žingsnio, o jos didumas svyruoja arti nulio. Todèl įveržtos ir lenkiamos jungties modelyje jos poveikio įveržimui nepaisoma.

Kitame skyriuje nagrinejjami srieginès jungties elementų poslinkių pokyčiai, kurie dèl lenkimo jungtyje atsiranda tarp dviejų skerspjūvių.

\subsubsection{Srieginès jungties elementų poslinkių darna}

Nagrinejjimui pasirinktoji jungties dalis yra kurio nors vieno ruožo dalis iš trijų, ivardytų 3.3 paveiksle. Nagrinejjamosios dalies pradžia yra ties koordinate $z_{0}$, o pabaiga ties koordinate $z$ (3.8 pav.). 


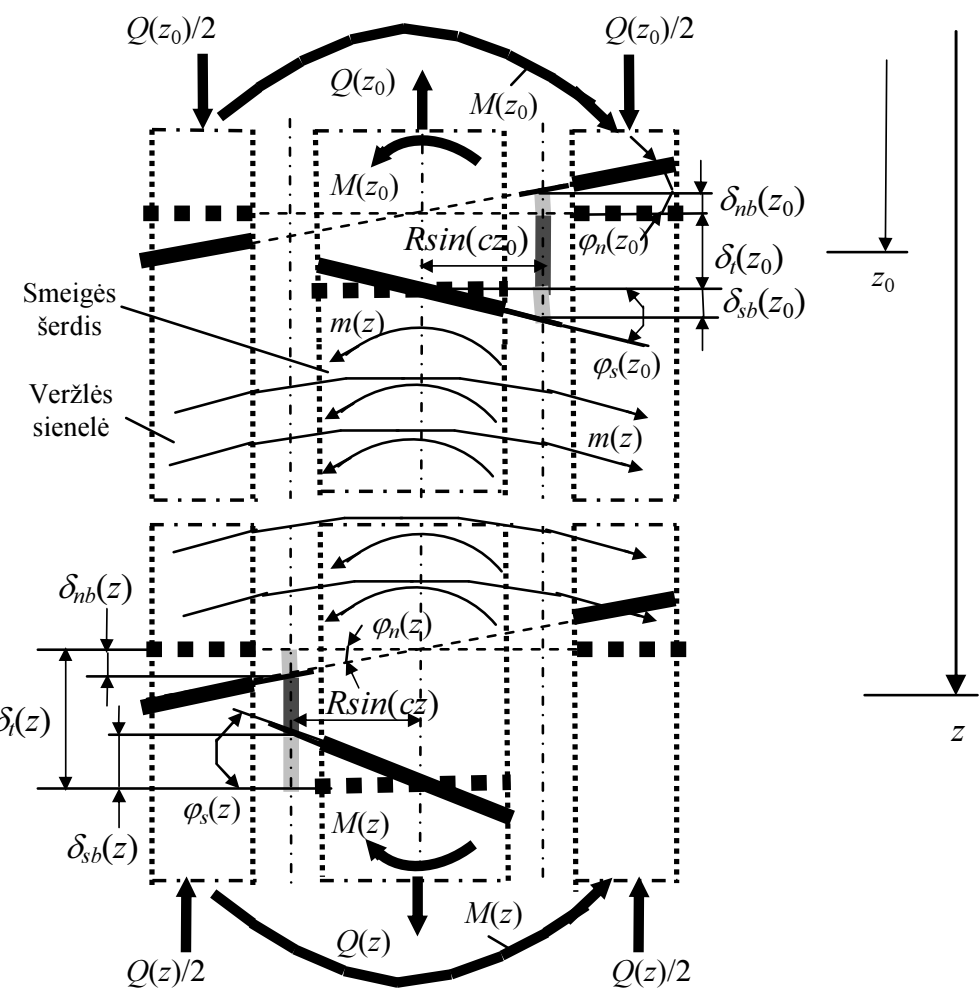

3.8 pav. Srieginès jungties elementų poslinkių pokyčiai

Fig. 3.8. Variations of displacements in threaded connection

Smeigès ir veržlès skerspjūvių $z$ kampiniai poslinkiai atžvilgiu atitinkamų skerspjūvių, esančių nagrinèjamos dalies pradžioje ties $z_{0}$, užrašyti, panaudojant ryšius (3.6) ir (3.7), atrodo taip:

$$
\begin{aligned}
& \varphi_{s}(z)-\varphi_{s}\left(z_{0}\right)=\frac{\delta_{b s}(z)}{R \sin (c z)}-\frac{\delta_{b s}\left(z_{0}\right)}{R \sin \left(c z_{0}\right)}, \\
& \varphi_{n}(z)-\varphi_{n}\left(z_{0}\right)=\frac{\delta_{b n}(z)}{R \sin (c z)}-\frac{\delta_{b n}\left(z_{0}\right)}{R \sin \left(c z_{0}\right)} .
\end{aligned}
$$

Pažymëjus $\Delta \varphi_{s}(z)=\varphi_{s}(z)-\varphi_{s}\left(z_{0}\right), \Delta \varphi_{n}(z)=\varphi_{n}(z)-\varphi_{n}\left(z_{0}\right)$, prisiminus, kad vijų poros ilinkiai yra $\delta_{b}(z)=\delta_{b s}(z)+\delta_{b n}(z), \delta_{b}\left(z_{0}\right)=\delta_{b s}\left(z_{0}\right)+\delta_{b n}\left(z_{0}\right)$, ir sudejus lygtis (3.11) su (3.12), yra gaunamas smeigès ir veržlès skerspjūvių tarpusavio posūkio (kampinio poslinkio) pokytis srieginès jungties ilgyje $\left(z-z_{0}\right)$ : 


$$
\Delta \varphi_{s}(z)+\Delta \varphi_{n}(z)=\frac{\delta_{b}(z)}{R \sin (c z)}-\frac{\delta_{b}\left(z_{0}\right)}{R \sin \left(c z_{0}\right)} .
$$

Smeigès ir veržlès skerspjūvių $z$ posūkiai atžvilgiu atitinkamų skerspjūvių, esančių ties $z_{0}$, priklauso nuo désnio, kuriuo vidinis lenkimo momentas kinta jungties atkarpoje $\left(z-z_{0}\right)$. Jo didumas skerspjūvyje $z$ yra

$$
M(z)=M\left(z_{0}\right)+\int_{z_{0}}^{z} m(z) d(z) .
$$

Minètieji skerspjūvių posūkiai išreiškiami smeigès ir veržlès kūnų illinkio diferencialinių lygčių integralais:

$$
\begin{aligned}
& \Delta \varphi_{s}(z)=\int_{z_{0}}^{z} \frac{M(z)}{E_{s} I_{s}} d z=\int_{z_{0}}^{z} \frac{M\left(z_{0}\right)+\int_{z_{0}}^{z} m(z) d z}{E_{s} I_{s}} d z, \\
& \Delta \varphi_{n}(z)=\int_{z_{0}}^{z} \frac{M(z)}{E_{n} I_{n}} d z=\int_{z_{0}}^{z} \frac{M\left(z_{0}\right)+\int_{z_{0}}^{z} m(z) d z}{E_{n} I_{n}} d z,
\end{aligned}
$$

čia $E_{s}, E_{n}$ ir $I_{s}, I_{n}$ - smeigès ir veržlès skerspjūvių tamprumo moduliai ir ašiniai inercijos momentai.

Panaudojus lygtis (3.1) ir (3.5), išskirstytą lenkimo momentą galima išreikšti per vijų poros ilinki tokiu pavidalu:

$$
m(z)=q_{b}(z) R \sin (c z)=\frac{\delta_{b}(\mathrm{z})}{\gamma(z)} R \sin (c z) .
$$

Išraišką (3.17) įstačius i lygtis (3.15) ir (3.16), o abi pastarąsias lygtis įstačius i (3.13), yra gauta lenkiamos srieginès jungties elementu poslinkių darnos integraline lygtis:

$$
\lambda \int_{z_{0}}^{z} M\left(z_{0}\right) d z+R \lambda \int_{z_{0} z_{0}}^{z} \frac{\delta_{b}(z)}{\gamma(z)} \sin (c z) d(z)=\frac{\delta_{b}(z)}{R \sin (c z)}-\frac{\delta_{b}\left(z_{0}\right)}{R \sin \left(c z_{0}\right)},
$$

čia

$$
\lambda=\frac{1}{E_{s} I_{s}}+\frac{1}{E_{n} I_{n}} .
$$




\subsubsection{Viju ilinkių diferencialinès lygtys}

Sprendžiant lygti (3.18), reikia ją du kartus diferencijuoti ir gauti diferencialinę lygti. Sprendimui supaprastinti buvo panaudotas pažymèjimas:

$$
y(z)=\frac{\delta_{b}(z)}{\sin (c z)} .
$$

Funkcija (3.20) išreiškia vijų poros įlinkio, kintančio pagal netaisyklingą sinusoidę, amplitudès kitimo dèsninguma. Po lygties (3.18) diferencijavimo ir ieškomosios funkcijos $\delta_{b}(z)$ pakeitimo išraiška $\delta_{b}(z)=y(z) \sin (c z)$, kurią duoda lygybè (3.20), lieka tokia lygtis:

$$
R \lambda M\left(z_{0}\right)+R^{2} \lambda \int_{z_{0}}^{z} \frac{y(z)}{\gamma(z)} \sin ^{2}(c z) d(z)=y^{\prime}(z) .
$$

Po lygybès (3.21) diferencijavimo gauta diferencialinè lygtis turi toki pavidalą:

$$
y^{\prime \prime}(z)-R^{2} \lambda \frac{y(z)}{\gamma(z)} \sin ^{2}(c z)=0 .
$$

Vijų ilinkių diferencialinè lygtis (3.22) yra tinkama, kai nagrinejjami srieginès jungties kraštiniai ruožai $(i=1$ arba $i=3)$, kur vijų porų paslankumo kitimą aprašo funkcija $\chi\left(z_{1}\right)$ arba $\chi\left(z_{3}\right)$. Lygtyje (3.22) ši funkcija išreiškia kintamaji koeficientą prie ieškomojo $y(z)$.

Viduriniame srieginès jungties ruože $(i=2)$, vijų poru paslankumas nekinta ir $\chi\left(z_{2}\right)=\gamma_{f}=$ const. Todèl, nagrinejjant antraji ruoža, lygti (3.22) naudinga perrašyti su pastoviuoju koeficientu prie ieškomojo $y(z)$ :

$$
y^{\prime \prime}(z)-\frac{R^{2} \lambda}{\gamma_{f}} y(z) \sin ^{2}(c z)=0 .
$$

Taigi, išsprendus diferencialines lygtis (3.22) ir (3.23), atitinkamiems ruožams gali būti nustatytos vijų ilinkių amplitudès funkcijos $y(z)$ ir vijų ilinkiai iš lygybès (3.20).

\subsubsection{Trijų ruožų srieginės jungties kraštinès sąlygos}

Tolesniam sprendimui reikia turèti vidinị lenkimo momentą, išreikštą per funkciją $y(z)$. Tokia jo išraiška yra gauta pertvarkius lygti (3.14), naudojant lygybes (3.20) ir (3.17). Atliekant veiksmus, paeiliui atsiranda tokios lygtys:

$$
M(z)=M\left(z_{0}\right)+\int_{z_{0}}^{z} \frac{\delta_{b}(\mathrm{z})}{\gamma(z)} R \sin (c z) d(z) .
$$




$$
M(z)=M\left(z_{0}\right)+R \int_{z_{0}}^{z} \frac{y(\mathrm{z})}{\gamma(z)} \sin ^{2}(c z) d(z) .
$$

Lygties (3.21) kairiojoje lygybės pusèje už skliaustų iškėlus $R \lambda$, apskliaustas lieka reiškinys (3.25). Tą pastebejjus, iš lygties (3.21) galima gauti vidinio lenkimo momento išraiška, kuri naudinga, nustatant kraštines sąlygas:

$$
M(z)=\frac{1}{R \lambda} y^{\prime}(z) .
$$

Dabar galima užrašyti kraštinių sąlygų bendras išraiškas, tinkamas visiems trims srieginės jungties ruožams (3.3 pav. ir 3.7 pav.):

$$
\begin{gathered}
M\left(z_{0}\right)=\frac{1}{R \lambda} y^{\prime}\left(z_{0}\right), \\
M\left(z_{H}\right)=\frac{1}{R \lambda} y^{\prime}\left(z_{H}\right) .
\end{gathered}
$$

Šioje disertacijoje kraštinių sąlygu išraiškos (3.27) ir (3.28) buvo panaudotos, sprendžiant diferencialines lygtis (3.22) ir (3.23) Rungès - Kuto metodu.

\subsection{Diferencialinių lygčių sprendiniai}

\subsubsection{Pastovaus standumo vijų ruožo diferencialinès lygties sprendinys}

Srieginès jungties ruože $H_{2}$ vijų paslankumas nekinta $\chi\left(z_{2}\right)=\gamma_{f}=$ const. Ivedus i diferencialinę lygti (3.23) pažymejjimą $b=R \lambda / \gamma_{f}$, jos pavidalas atrodo taip:

$$
y^{\prime \prime}(z)-b y(z) \sin ^{2}(c z)=0 .
$$

Pasirinkto diferencialinès lygties (3.29) apytikrio analitinio sprendinio forma yra tokia:

$$
y(z)=A \sinh (n z)+B \cosh (n z)=A f_{f A}(z)+B f_{f B}(z) .
$$

Žinant, kad antrajame jungties ruože $i=2$, lygtyje (3.30) ir kitose šio skyriaus formulèse naudojami tokie sutrumpinimai: $z=z_{2}, z_{0}=z_{02}, A=A_{2}$ ir $B=B_{2}$. Sprendiniui (3.30) reikia nustatyti pastoviojo koeficiento $n$ išraišką. Pirmiausiai lygties (3.30) išvestine $y^{\prime}(z)$ istatoma ị lygtị (3.26) ir gaunamas (toliau vadinamojo) vidutiniojo momento pavidalas: 


$$
\begin{gathered}
M_{m}(z)=\frac{1}{R \lambda} y^{\prime}(z)=\frac{A n}{R \lambda} \cosh (n z)+\frac{B n}{R \lambda} \sinh (n z)= \\
=A \frac{f_{f A}^{\prime}(z)}{R \lambda}+B \frac{f_{f B}^{\prime}(z)}{R \lambda} .
\end{gathered}
$$

Kita lenkimo momento išraiška gauta (prisiminus, kad vijų paslankumas viduriniame jungties ruože yra $\left.\chi\left(z_{2}\right)=\gamma_{f}\right)$, lygti (3.30) istačius i (3.25) ir gautaji rezultatą integravus:

$$
\begin{gathered}
M(z)=M\left(z_{0}\right)+\frac{R}{\gamma_{f}} \int_{z_{0}}^{z} y(z) \sin ^{2}(c z) d z= \\
=M\left(z_{0}\right)+\frac{R}{\gamma_{f}} \int_{z_{0}}^{z} A \sinh (n z) \sin ^{2}(c z) d z+\frac{R}{\gamma_{f}} \int_{z_{0}}^{z} B \cosh (n z) \sin ^{2}(c z) d z= \\
=A F_{f A}(z)+B F_{f B}(z) .
\end{gathered}
$$

Daugikliai $F_{f A}(z)$ ir $F_{f B}(z)$ prie pastoviujų koeficientų $A$ ir $B$ lygtyje (3.32) yra tokie:

$$
\begin{aligned}
& F_{f A}(z)=\frac{R}{\gamma_{f}} \cdot \frac{1}{n^{2}+4 c^{2}}\left[n \cdot \cosh (n z) \sin ^{2}(c z)-c \cdot \sinh (n z) \sin (2 c z)+\frac{2 c^{2}}{n} \cosh (n z)\right], \\
& F_{f B}(z)=\frac{R}{\gamma_{f}} \cdot \frac{1}{n^{2}+4 c^{2}}\left[n \cdot \sinh (n z) \sin ^{2}(c z)-c \cdot \cosh (n z) \sin (2 c z)+\frac{2 c^{2}}{n} \sinh (n z)\right] .
\end{aligned}
$$

Išnagrinëjus funkcijų (3.31) ir (3.33) kitimo pobūdi, paaiškèjo, kad esant tam tikroms kintamojo reikšmėms $z=z^{*}$, galioja lygybe் $M\left(z^{*}\right)=M_{m}\left(z^{*}\right)$, kuri iliustruojama pavyzdžiu C priede. Ši lygybė galioja, kai lygčių (3.31) ir (3.32) daugikliai prie $A$ ir $B$ yra lygūs.

Kai $c z^{*}=k_{1}(\pi / 4)$ ir kai $k_{1}=0,1,3,5,7 \ldots, \sin \left(2 c z^{*}\right)=0$ ir $\sin \left(c z^{*}\right)=1$, lygčių (3.31) ir (3.32) daugiklių prie $A$ ir prie $B$ lygybès yra tokios:

$$
\begin{aligned}
& \frac{R}{\gamma_{f}} \cdot \frac{1}{n^{2}+4 c^{2}}\left[n \cdot \cosh (n z)+\left(2 c^{2} / n\right) \cosh (n z)\right]=\frac{n}{R \lambda} \cosh (n z), \\
& \frac{R}{\gamma_{f}} \cdot \frac{1}{n^{2}+4 c^{2}}\left[n \cdot \sinh (n z)+\left(2 c^{2} / n\right) \sinh (n z)\right]=\frac{n}{R \lambda} \sinh (n z) .
\end{aligned}
$$


Atlikę suprastinimus lygtyse (3.35) ir (3.36), gauname vienodą išraišką:

$$
n^{4}+n^{2}\left(4 c^{2}-b\right)-2 b c^{2}=0 .
$$

Lygties (3.37) sprendinys yra:

$$
n=\sqrt{0.5\left[-\left(4 c^{2}-b\right)+\sqrt{16 c^{4}+b^{2}}\right]} .
$$

Kitu atveju, kai $z^{*}=k_{2}(\pi / 2)$ ir kai $k_{2}=0,1,2,3,4,5 \ldots, \sin \left(2 c z^{*}\right)=0$ ir $\sin \left(c z^{*}\right)=0$, lygčiu (3.31) ir (3.32) daugiklių prie $A$ ir prie $B$ lygybès yra tokios:

$$
\begin{aligned}
& \frac{R}{\gamma_{f}} \cdot \frac{1}{n^{2}+4 c^{2}}\left[\left(2 c^{2} / n\right) \cosh (n z)\right]=\frac{n}{R \lambda} \cosh (n z), \\
& \frac{R}{\gamma_{f}} \cdot \frac{1}{n^{2}+4 c^{2}}\left[\left(2 c^{2} / n\right) \sinh (n z)\right]=\frac{n}{R \lambda} \sinh (n z) .
\end{aligned}
$$

Atlikę suprastinimus lygtyse (3.39) ir (3.40), gauname vèl vienodą išraišką:

$$
n^{4}+4 c^{2} n^{2}-2 b c^{2}=0 .
$$

Lygties (3.41) sprendinys yra:

$$
n=\sqrt{-2 c^{2}+c \sqrt{4 c^{2}+2 b}} .
$$

Išraiškos (3.38) ir (3.42) duoda praktiškai vienodas koeficiento $n$ reikšmes. Pavyzdžiui, jungčiai M16 $\times 2$, pagal šias formules apskaičiuotos atitinkamos $n$ reikšmès yra $n=0,15640$ ir $n=0,15630$. Geras diferencialinès lygties (3.29) skaitinio sprendinio (Rungès - Kuto metodas) sutapimas su skaičiavimų rezultatais, gautais taikant čia pateiktą analitini modeli, parodè, kad koeficiento $n$ reikšmè, nustatyta pagal (3.38) formulę (arba pagal (3.42)), tinka ir tuomet, kai $z \neq z^{*}$. Skaičiavimo rezultatų palyginimas yra pateiktas skyriuje 3.2.5.

Taigi, analitini sprendini ruožui $H_{2}$ sudaro vijų poros įlinkio amplitudès funkcija (3.30) ir vidinio lenkimo momento išraiška (3.32). Funkcijos $y\left(z_{2}\right)$ apytikslès išraiškos (3.30) išvestinè negali būti taikoma vidiniam lenkimo momentui $M\left(z_{2}\right)$ skaičiuoti pagal formulę (3.26).

\subsubsection{Kintamo standumo vijų ruožo diferencialinès lygties sprendinys}

Srieginès jungties ruožuose $H_{1}$ ir $H_{3}$ vijų paslankumas kinta $\chi(z) \neq c o n s t$, kai $i=1$ arba $i=3$. Šiu ruožų atvejams skirtą diferencialinę lygti (3.22) perrašome tokiu pavidalu: 


$$
\gamma(z) y^{\prime \prime}(z)-R^{2} \lambda y(z) \sin ^{2}(c z)=0 .
$$

Diferencialinès lygties (3.43) apytikris sprendinys ieškomas tokioje formoje:

$$
y(z)=A e^{n_{A} z}\left(n_{A} z+W_{A}\right)+B e^{n_{B} z}\left(-n_{B} z+W_{B}\right)=A f_{p A}(z)+B f_{p B}(z),
$$

čia $n_{A}, W_{A}, n_{B}$ ir $W_{B}$ yra koeficientai, kuriuos dar reikia nustatyti, $f_{p A}(z)$ ir $f_{p B}(z)$ yra kintamų daugiklių prie $A$ ir $B$ pažymejjimai.

Koeficientai $n_{A}, W_{A}, n_{B}$ ir $W_{B}$ nustatomi sulyginus dvi lenkimo momento išraiškas. Pirmoji išraiška gaunama lygties (3.44) išvestinę $y^{\prime}(z)$ istačius i lygti (3.26):

$$
\begin{gathered}
M^{*}(z)=\frac{y^{\prime}(z)}{R \lambda}=A \frac{f_{p A}^{\prime}(z)}{R \lambda}+B \frac{f_{p B}^{\prime}(z)}{R \lambda}= \\
=A \frac{n_{A} e^{n_{A} z}\left(n_{A} z+W_{A}+1\right)}{R \lambda}+B \frac{n_{B} e^{n_{B} z}\left(-n_{B} z+W_{B}-1\right)}{R \lambda} .
\end{gathered}
$$

Kita lenkimo momento išraiška gaunama (prisiminus, kad vijų paslankumai kraštiniu jungties ruožų atveju aprašomi lygtimi (3.9)) išraišką (3.44) įstačius i lygti (3.25) ir gautą rezultatą integravus:

$$
M(z)=M\left(z_{0}\right)+\int_{z_{0}}^{z} \frac{\left\lfloor A f_{p A}(z)+B f_{p B}(z)\right\rfloor}{V e^{u z}} R \sin ^{2}(c z) d z=A F_{p A}(z)+B F_{p B}(z) .
$$

Pažymejus $t_{A}=n_{A}-u, p_{A}=t_{A}^{2}+4 c^{2}$ ir $t_{B}=n_{B}-u, p_{B}=t_{B}^{2}+4 c^{2}$ lygties (3.46) atitinkami daugikliai $F_{p A}(z)$ ir $F_{p B}(z)$ prie pastoviujų koeficientu $A$ ir $B$ yra tokie:

$$
\begin{aligned}
& F_{p A}(z)=\frac{\mathrm{Re}^{t_{A} z}}{2 V}\left[+\frac{n_{A}\left(t_{A} z-1\right)}{t_{A}^{2}}-n_{A}\left(\left(t_{A} z-\frac{t_{A}^{2}-4 c^{2}}{p_{A}}\right) \frac{\cos (2 c z)}{p_{A}}-\right.\right. \\
& \left.\left.-\left(\frac{4 c t_{A}}{p_{A}}-2 c z\right) \frac{\sin (2 c z)}{p_{A}}\right)-\frac{W_{A}}{p_{A}}\left(t_{A} \cos (2 c z)+2 c \sin (2 c z)\right)+\frac{W_{A}}{t_{A}}\right], \\
& F_{p B}(z)=\frac{\operatorname{Re}^{t_{B} z}}{2 V}\left[-\frac{n_{B}\left(t_{B} z-1\right)}{t_{B}^{2}}+n_{B}\left(\left(t_{B} z-\frac{t_{B}^{2}-4 c^{2}}{p_{B}}\right) \frac{\cos (2 c z)}{p_{B}}-\right.\right. \\
& \left.\left.-\left(\frac{4 c t_{B}}{p_{B}}-2 c z\right) \frac{\sin (2 c z)}{p_{B}}\right)-\frac{W_{B}}{p_{B}}\left(t_{B} \cos (2 c z)+2 c \sin (2 c z)\right)+\frac{W_{B}}{t_{B}}\right] .
\end{aligned}
$$

Koeficientų $n_{A}, W_{A}, n_{B}$ ir $W_{B}$ reikšmès nustatomos laikant, kad momentų lygybè $M^{*}\left(z^{*}\right)=M\left(z^{*}\right)$ t. y. lygčiu (3.45) ir (3.46) lygybė galioja dviejuose nagrinèjamo kraštinio jungties ruožo taškuose: $z^{*}=z_{0}+\mathrm{P} / 4$ ir $z^{*}=z_{H}-\mathrm{P} / 4$. Ši lygybè galioja 
tik tada, kai lygčiu (3.45) ir (3.46) daugikliai prie $A$ ir $B$ yra lygūs. Tuomet koeficientų $n_{A}$ ir $W_{A}$ reikšmès gaunamos išsprendus tokią lygčių sistemą:

$$
\frac{f_{p A}^{\prime}\left(z_{0}+P / 4\right)}{R \lambda}=F_{p A}\left(z_{0}+P / 4\right), \quad \frac{f_{p A}^{\prime}\left(z_{H}-P / 4\right)}{R \lambda}=F_{p A}\left(z_{H}-P / 4\right) .
$$

Koeficientų $n_{B}$ ir $W_{B}$ reikšmés gaunamos išsprendus analogišką lygčių sistemą:

$$
\frac{f_{p B}^{\prime}\left(z_{0}+P / 4\right)}{R \lambda}=F_{p B}\left(z_{0}+P / 4\right), \quad \frac{f_{p B}^{\prime}\left(z_{H}-P / 4\right)}{R \lambda}=F_{p B}\left(z_{H}-P / 4\right) .
$$

Lygčių sistemos (3.49) ir (3.50) buvo sprendžiamos naudojant matematini paketą Maple-9. Atliekant skaitini eksperimenta, buvo isitikinta, kad funkcijų $M^{*}\left(z^{*}\right)$ ir $M\left(z^{*}\right)$ sutapimą pakanka pasiekti tik dviejuose taškuose ir kad parinktos šių taškų koordinatès $z^{*}$ duoda geriausią diferencialinès lygties (3.43) analitinio sprendinio atitikti skaitiniams rezultatams, gautiems Rungès - Kuto metodu. Šis palyginimas pateiktas 3.2.5. skyriuje. Funkcijų, nurodytų lygybėse (3.49) ir (3.50), sankirtų iliustracijos parodytos $\mathrm{C}$ priede.

Taigi analitinị sprendinį ruožams $H_{1}$ ir $H_{3}$ sudaro vijų poros ịlinkio aplitudès funkcija (3.44) ir vidinio lenkimo momento išraiška (3.46). Funkcijų $y\left(z_{1}\right)$ ir $y\left(z_{3}\right)$, nustatytų pagal (3.44), išvestinès $y^{\prime}\left(z_{1}\right)$ ir $y^{\prime}\left(z_{3}\right)$ negali būti taikomos vidiniams lenkimo momentams $M\left(z_{1}\right)$ ir $M\left(z_{3}\right)$ skaičiuoti pagal formulę (3.26).

\subsubsection{Analitinio sprendinio lygčių visuma}

Trijų ruožų srieginès jungties sprendini, ivertinantị tik lenkimo poveiki, sudaro visuma lygčių, aprašančių vijų apkrovų $q_{b}\left(z_{i}\right)$ ir vidinio lenkimo momento $q_{b}\left(z_{i}\right)$ $M\left(z_{i}\right)$ pasiskirstymą jungties ilgyje. Viju apkrovos ir lenkimo momentas tiesiogiai naudojami vietinių itempių, atsirandančių sriegio įdubose, skaičiuoti. Todèl, prisiminus ryšius (3.5), (3.8) ir (3.9), minètają visumą galima aprašyti tokiomis lygtimis:

$$
\begin{gathered}
q_{b}\left(z_{1}\right)=\delta_{b}\left(z_{1}\right) / \gamma\left(z_{1}\right)=V_{1}^{-1} e^{-u_{1} z_{1}}\left[A_{1} f_{p A}\left(z_{1}\right)+B_{1} f_{p B}\left(z_{1}\right)\right] \sin \left(c z_{1}\right), \\
M\left(z_{1}\right)=A_{1} F_{p A}\left(z_{1}\right)+B_{1} F_{p B}\left(z_{1}\right), \\
q_{b}\left(z_{2}\right)=\delta_{b}\left(z_{2}\right) / \gamma\left(z_{2}\right)=\gamma_{f}^{-1}\left[A_{2} f_{f A}\left(z_{2}\right)+B_{2} f_{f B}\left(z_{2}\right)\right] \sin \left(c z_{2}\right), \\
M\left(z_{2}\right)=A_{2} F_{f A}\left(z_{2}\right)+B_{2} F_{f B}\left(z_{2}\right), \\
q_{b}\left(z_{3}\right)=\delta_{b}\left(z_{3}\right) / \gamma\left(z_{3}\right)=V_{3}^{-1} e^{-u_{3} z_{3}}\left[A_{3} f_{p A}\left(z_{3}\right)+B_{3} f_{p B}\left(z_{3}\right)\right] \sin \left(c z_{3}\right), \\
M\left(z_{3}\right)=A_{3} F_{p A}\left(z_{3}\right)+B_{3} F_{p B}\left(z_{3}\right) .
\end{gathered}
$$




\subsubsection{Lenkiamos jungties trijų ruožų kraštinès sąlygos}

Trijų ruožų lenkiamos jungties sprendinio lygtyse esantiems pastoviesiems koeficientams $A_{i}$ ir $B_{i}$ nustatyti reikia panaudoti žinomas kraštines sąlygas, susidarančias jungties ruožų sandūrose. Kraštinès sąlygos, susidarančios jungties ruožų sandūrose parodytos 3.9 paveiksle.

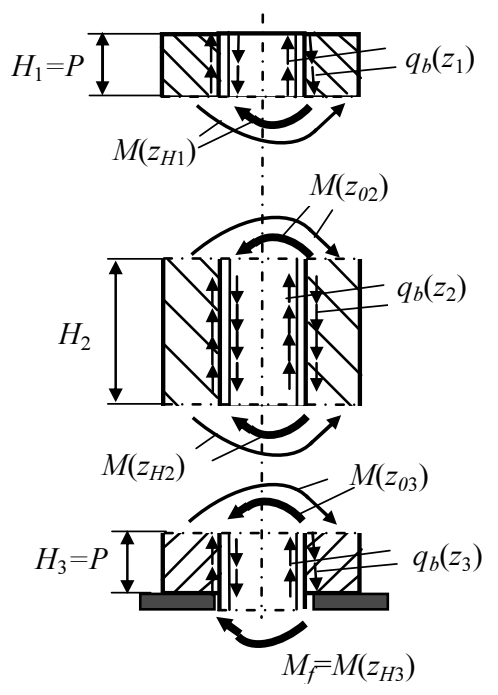

3.9 pav. Lenkiamos srieginès jungties kraštinès sąlygos

Fig. 3.9. Boundary conditions in bent threaded connection

3.9 paveiksle storesnėmis linijomis yra pažymèti lenkimo momentai, kurie veikia smeigès šerdi, o plonesni vektoriai lenkia veržlès vamzdini skerspjūvị.

Jungties ruožų sandūrose, gretimų ruožų smeigès ir veržlès skerspjūvių vidiniai lenkimo momentai, vijų apkrova ir jai proporcingi vijų porų įlinkiai yra lygūs. Todèl kraštines sąlygas galima išreikšti lygčių (3.57-3.62) sistema:

$$
\begin{gathered}
M\left(z_{01}\right)=0, \quad \text { arba } A_{1} F_{p A}\left(z_{01}\right)+B_{1} F_{p B}\left(z_{01}\right)=0, \\
M\left(z_{H 1}\right)=M\left(z_{02}\right), \text { arba } A_{1} F_{p A}\left(z_{H 1}\right)+B_{1} F_{p B}\left(z_{H 1}\right)=A_{2} F_{f A}\left(z_{02}\right)+B_{2} F_{f B}\left(z_{02}\right), \\
M\left(z_{H 2}\right)=M\left(z_{03}\right), \text { arba } A_{2} F_{f A}\left(z_{H 2}\right)+B_{2} F_{f B}\left(z_{H 2}\right)=A_{3} F_{p A}\left(z_{03}\right)+B_{3} F_{p B}\left(z_{03}\right), \\
M\left(z_{H 3}\right)=M_{f}, \quad \text { arba } A_{3} F_{p A}\left(z_{H 3}\right)+B_{3} F_{p B}\left(z_{H 3}\right)=M_{f}, \\
\delta_{b}\left(z_{H 1}\right)=\delta_{b}\left(z_{02}\right), \quad \text { arba } A_{1} f_{p A}\left(z_{H 1}\right)+B_{1} f_{p B}\left(z_{H 1}\right)=A_{2} f_{f A}\left(z_{02}\right)+B_{2} f_{f B}\left(z_{02}\right), \\
\delta_{b}\left(z_{H 2}\right)=\delta_{b}\left(z_{03}\right), \quad \text { arba } A_{2} f_{f A}\left(z_{H 2}\right)+B_{2} f_{f B}\left(z_{H 2}\right)=A_{3} f_{p A}\left(z_{03}\right)+B_{3} f_{p B}\left(z_{03}\right) .
\end{gathered}
$$


Išsprendus pateiktą šešių lygčių sistemą, nustatomos šešių koeficientų $\left(A_{1}, B_{1}\right.$, $A_{2}, B_{2}, A_{3}, B_{3}$ ) reikšmès.

\subsubsection{Analitinių ir skaitinių sprendinių palyginimas}

Diferencialinių lygčių (3.29) ir (3.43) apytikslių analitinių sprendinių tikslumo patikrinimas buvo atliktas, lyginant analitiniu ir skaitiniu (Rungès - Kutto metodas) metodais gautus skaičiavimo rezultatus (3.10 pav.).
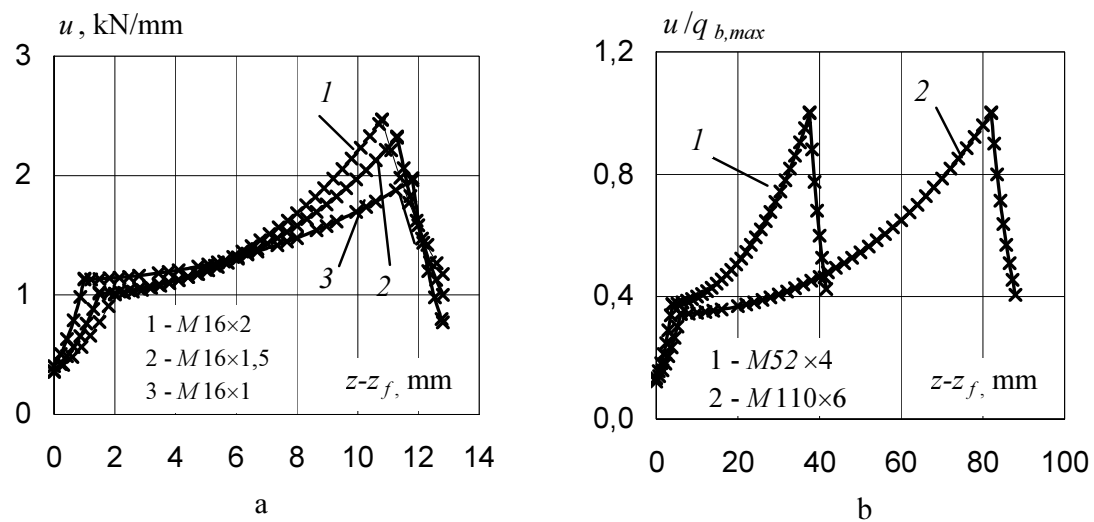

3.10 pav. Analitiniu ir Rungès - Kutto metodais apskaičiuotų rezultatų palyginimas: sriegio žingsnio įtaka (a); srieginès jungties didumo įtaka (b);

ištisinès kreivès - analitinis metodas, kryžiukai - Rungès - Kutto metodas

Fig. 3.10. Comparing of the results calculated by analytical and Runge-Kutta methods: thread pitch influence (a); influence of the overall dimensions (b);

solid curves - analytical method, points by criss cross - Runge-Kutta method

Kadangi srieginès jungties modelị sudaro trys ruožai, kuriuos aprašo atskiros diferencialinès lygtys, tai Rungès - Kutto metodas nagrinèjamo uždavinio atveju gali būti taikomas tik atskirai kiekvienam ruožui. Sprendžiant kiekvieną diferencialinę lygti atskirai, būtinos nagrinejjamo ruožo kraštinès salygos, kurios iš anksto nèra žinomos. Todèl iš pradžių buvo atliekamas skaičiavimas remiantis analitinius sprendinius, kur kraštinès sąlygos nustatomos iš lygčiu sistemos (3.57-3.62). Toliau, taikant žinomus momentus $M\left(z_{01}\right)=0, M\left(z_{H 3}\right)=M_{f}$ ir analitiniu būdu gautas kraštinių sąlygų reikšmes $M\left(z_{02}\right), M\left(z_{03}\right)$, pagal formulę (3.54) kiekvieno ruožo kraštams nustatomos ilinkių amplitudès funkcijos išvestinès $y^{\prime}\left(z_{01}\right), y^{\prime}\left(z_{02}\right), y^{\prime}\left(z_{03}\right), y^{\prime}\left(z_{H 3}\right)$. Šių išvestinių reikšmès tiesiogiai naudojamos sprendžiant diferencialines lygtis Rungès -Kutto metodu. Sprendiniai gauti, taikant matematini paketą Maple-9. 
Duomenų, apskaičiuotų analitiniu ir Rungès - Kutto metodais, palyginimas atliktas atsižvelgiant ị srieginèms jungtims būdingus faktorius: sriegio žingsnị ir jungties gabaritus (3.10 pav. ir 3.11 pav.).

Skaičiavimai buvo atlikti jungtims M16×1, M16×1,5, M16×2, M52×4 ir M110×6. Jungčiai M16×2 skaičiavimai buvo atlikti, esant keturioms skirtingoms sraigtinès linijos padètims I, II, III ir IV.
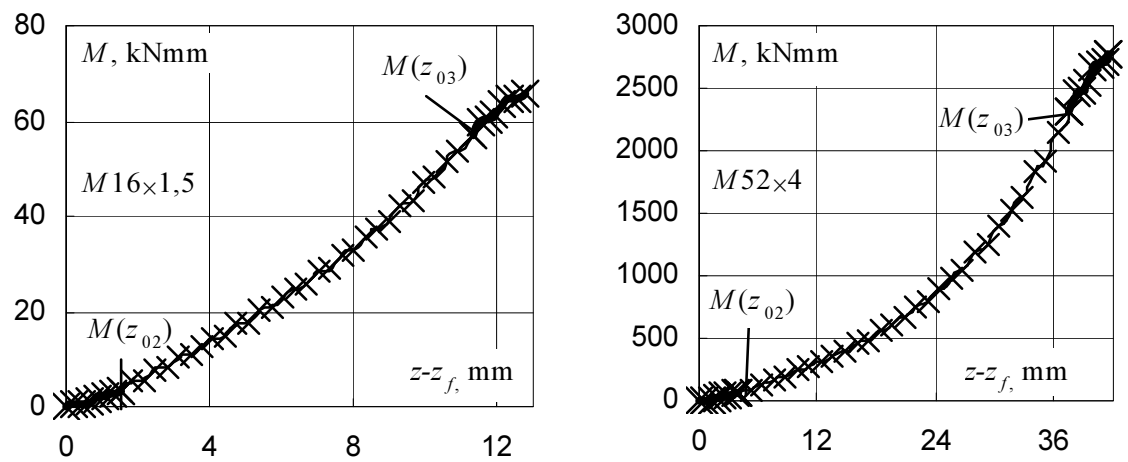

3.11 pav. Analitiniu ir Rungès - Kutto metodais apskaičiuotų lenkimo momentų palyginimas: ištisinès kreivès - analitinis metodas, kryžiukai - Rungès - Kutto metodas Fig. 3.11. Comparing of the bending moments calculated by analytical and Runge-Kutta methods: solid curves - analytical method, points by criss cross - Runge-Kutta method

Skaitinès funkcijų $u\left(z_{i}\right)$ ir $M\left(z_{i}\right)$ reikšmès, nustatytos analitiniu ir RungeKutta metodais, skiriasi nežymiai, ne daugiau kaip $1 \%$. Tas liečia kraštinius srieginès jungties ruožus $H_{1}, H_{3}$ ir vidurinị ruožą $H_{2}$.

\subsubsection{Ašinès irąžos ir sriegio vijų apkrovos}

Ašinèms įrąžoms $Q_{t}\left(z_{i}\right)$ ir vijų apkrovoms $q_{t}\left(z_{i}\right)$, kurios atsiranda necentriškai tempiant srieginę jungti (3.12 pav.), skaičiuoti šiame darbe taikoma VGTU stiprumo mechanikos mokslo laboratorijoje sudaryta metodika (Selivonec, et al. 2004). Ašinès įrąžos ir vijų apkrovos tiesiogiai yra naudojamos vietinių įtempių, atsirandančių smeigès sriegio i̇dubose, skaičiavimui. Ašinių iražųu ir vijų apkrovų ryši su vijų ilinkias $\delta_{t}\left(z_{i}\right)$ išreiškia tokios lygtys:

$$
q_{t}\left(z_{i}\right)=\frac{\delta_{t}\left(z_{i}\right)}{\gamma\left(z_{i}\right)}
$$




$$
Q_{t}\left(z_{i}\right)=\frac{\delta_{t}^{\prime}\left(z_{i}\right)}{\beta},
$$

čia $\beta=1 /\left(E_{s} A_{s}\right)+1 /\left(E_{n} A_{n}\right), A_{s}$ ir $A_{n}$ yra smeigès šerdies ir veržlès sienelès skerspjūvių plotai

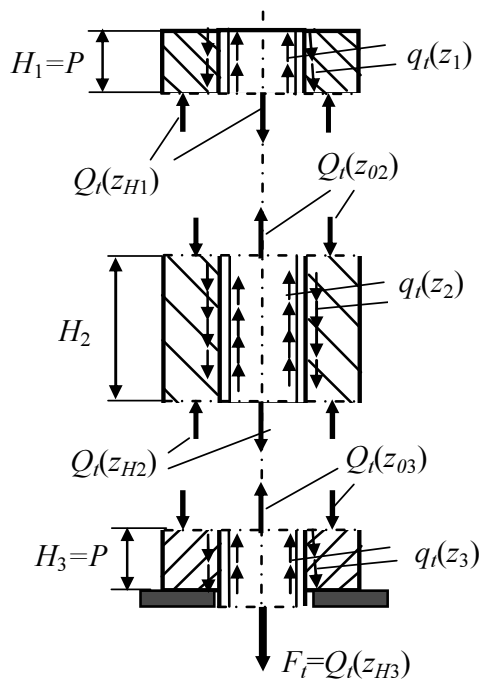

3.12 pav. Tempiamos srieginès jungties kraštinès sąlygos

Fig. 3.12. Boundary conditions at tension of the threaded connection

Trijų ruožų jungčiai lygčių visuma, kuri reikalinga vijų apkrovų ir vidinių ašinių jègų skaičiavimui, yra tokia

$$
\begin{gathered}
q_{t}\left(z_{1}\right)=\delta_{t}\left(z_{1}\right) / \gamma\left(z_{1}\right)=\left[A_{t 1} f_{t p A}\left(z_{1}\right)+B_{t 1} f_{t p B}\left(z_{1}\right)\right] / \gamma\left(z_{1}\right), \\
Q_{t}\left(z_{1}\right)=A_{t 1} F_{t p A}\left(z_{1}\right)+B_{t 1} F_{t p B}\left(z_{1}\right), \\
q_{t}\left(z_{2}\right)=\delta_{t}\left(z_{2}\right) / \gamma_{f}=\left[A_{t 2} f_{t f A}\left(z_{2}\right)+B_{t 2} f_{t f B}\left(z_{2}\right)\right] / \gamma, \\
Q_{t}\left(z_{2}\right)=A_{t 2} F_{t f A}\left(z_{2}\right)+B_{t 2} F_{t f B}\left(z_{2}\right), \\
q_{t}\left(z_{3}\right)=\delta_{t}\left(z_{3}\right) / \gamma\left(z_{3}\right)=\left[A_{t 3} f_{t p A}\left(z_{3}\right)+B_{t 3} f_{t p B}\left(z_{3}\right)\right] / \gamma\left(z_{3}\right), \\
Q_{t}\left(z_{3}\right)=A_{t 3} F_{t p A}\left(z_{3}\right)+B_{t 3} F_{t p B}\left(z_{3}\right) .
\end{gathered}
$$

Išeinančių iš sukibimo vijų ruožams $(i=1$ ir $i=3)$ skirtose lygtyse $(3.66,3.67$ ir $3.42,3.71)$ kintamaji viju paslankumą $\chi\left(z_{i}\right)$ ir kintamuosius daugiklius prie pastoviuju $A_{t i}$ ir $B_{t i}$ išreiškia lygybès: 


$$
\begin{aligned}
& \gamma\left(z_{i}\right)=\frac{\beta}{C_{t i}^{2} e^{2 n_{t i} z_{i}}+C_{t i} n_{t i} e^{n_{t i} z_{i}}}, \\
& f_{t p A}\left(z_{i}\right)=e^{-\frac{\tau_{i}}{2}}, \quad f_{t p B}\left(z_{i}\right)=\frac{1}{n_{t i}} e^{-\frac{\tau_{i}}{2}}\left(\ln \tau_{i}+\frac{\tau_{i}}{1 \cdot 1 !}+\frac{\tau_{i}^{2}}{2 \cdot 2 !}+\ldots\right) \text {, } \\
& F_{t p A}\left(z_{i}\right)=-\tau_{i} n_{t i} e^{-\tau_{i} / 2}, \\
& F_{t p B}\left(z_{i}\right)=\left(-\tau_{i} e^{-\tau_{i} / 2}\left(\ln \tau_{i}+\frac{\tau_{i}}{1 \cdot 1 !}+\frac{\tau_{i}^{2}}{2 \cdot 2 !}+\ldots\right)+e^{\tau_{i} / 2}\right) \text {, }
\end{aligned}
$$

čia $\tau_{i}=-2 \frac{C_{t i}}{n_{t i}} e^{n_{t i} z_{i}}, C_{t i}$ ir $n_{t i}$ yra pastovieji koeficientai.

Viduriniajam jungties ruožui $(i=2)$ skirtose lygtyse (3.67 ir 3.68) viju paslankumas $\gamma$ yra nekintamas dydis, o kintamieji daugikliai prie pastoviujų $A_{t 2}$ ir $B_{t 2}$ išreiškiami lygybèmis:

$$
\begin{array}{cc}
f_{t p A}\left(z_{2}\right)=\sinh \left(m_{t} z_{2}\right), & f_{t p B}\left(z_{2}\right)=\cosh \left(m_{t} z_{2}\right), \\
F_{t p A}\left(z_{2}\right)=m_{t} \cosh \left(m_{t} z_{2}\right), & F_{t p B}\left(z_{2}\right)=m_{t} \sinh \left(m_{t} z_{2}\right),
\end{array}
$$

čia $m_{t}=\left(\beta / \gamma_{f}\right)^{0,5}$.

Trijų ruožų izveržtos jungties sprendinio lygtyse esantiems šešiems pastoviesiems koeficientams $A_{i}$ ir $B_{i}$ nustatyti reikia pasinaudoti žinomomis kraštinèmis sąlygomis, susidarančiomis jungties ruožų sandūrose. Jungties ruožu sandūrose, gretimų ruožų smeigès ir veržlès skerspjūvių vidinės ašinės jẻgos, vijų apkrova ir jai proporcingi vijų porų įlinkiai yra lygūs. Todèl kraštines sąlygas galima išreikšti tokiomis lygybèmis:

$$
\begin{gathered}
Q\left(z_{01}\right)=0, \quad Q\left(z_{H 1}\right)=Q\left(z_{02}\right), \quad Q\left(z_{H 2}\right)=Q\left(z_{03}\right), \quad Q\left(z_{H 3}\right)=F_{t}, \\
q_{t}\left(z_{H 1}\right)=q_{t}\left(z_{02}\right), \quad q_{t}\left(z_{H 2}\right)=q_{t}\left(z_{03}\right) .
\end{gathered}
$$

Ašine jèga apkrautos srieginès jungties modelis ịvertina viju paslankumo savybes, kurias viju poros turi kraštiniuose ir viduriniajame jungties ruožuose. Todèl šis modelis tinka įveržtos ir lenkiamos srieginès jungties ašinių iražų ir atitinkamų vijų apkrovų skaičiavimui. 


\subsection{Irąžu, vijų apkrovų ir vietinių itempių pasiskirstymas necentriškai tempiamose srieginèse jungtyse}

\subsubsection{Irąžų ir viju apkrovų pasiskirstymas}

Irąžų ir vijų apkrovų skaičiavimo galimybès, kurias duoda analitinis lenkiamos jungties modelis, šiame skyriuje iliustruojamas skaičiavimo pavyzdžiais srieginei jungčiai M16×2. Veržlès ilgis yra $H=0,8 d=12,8 \mathrm{~mm}$. Jungtis pagaminta iš plieno $25 \mathrm{X} 1 \mathrm{M} \Phi$. Nominalūs ivveržimo ir lenkimo įtempiai smeigès šerdyje yra $\sigma_{t, n o m} / R_{p 0.02}=0,6$ ir atitinkamai $\sigma_{b, n o m, \max } / R_{p 0.02}=0,31$. Ašinè išorinè jèga yra $F_{t}=74,5 \mathrm{kN}$. Išorinis lenkimo momentas $M_{f}=66 \mathrm{kNmm}$. Formulès, pasitelktos skaičiuojant, pateiktos 3.2. skyriuje.

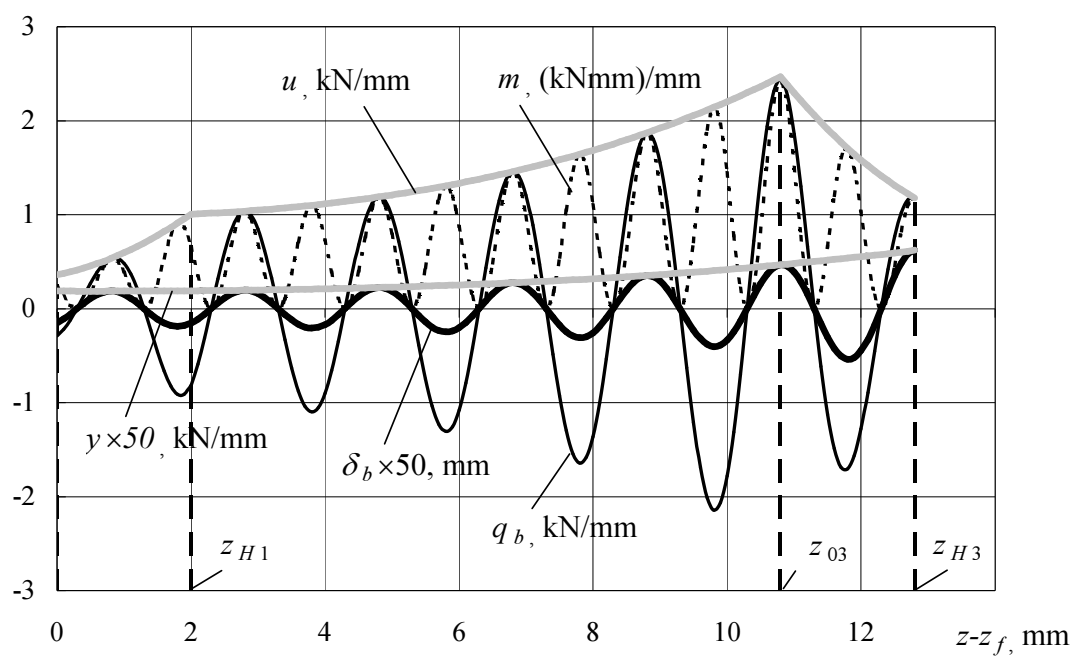

3.13 pav. Vijų porų M16 $\times 2$ įlinkiai, išskirstytos apkrovos ir išskirstyti momentai

Fig. 3.13. Deflections, load and moment intensities of turn pairs $M 16 \times 2$

3.13 paveiksle parodyta, kaip srieginejje jungtyje M16×2 kinta viju ilinkiai $\delta_{b}$, ir vijų ilinkių amplitudès funkcija $y$, vijų apkrova $q_{b}$ ir vijų apkrovos amplitudžių funkcija $u$, bei išskirstytas lenkimo momentas $m$.

$3.14,3.15$ ir 3.16 paveiksluose parodyti grafikai iliustruoja dėsningumus, pagal kuriuos kinta vijų apkrovų $q_{t}(z)$ ir $q_{b}(z)$, bei iražų $Q(z)$ ir $M(z)$ reikšmès, 
kurios taikomos vietiniam įtempiams, atsirandantiems smeigès sriegyje, apskaičiuoti.
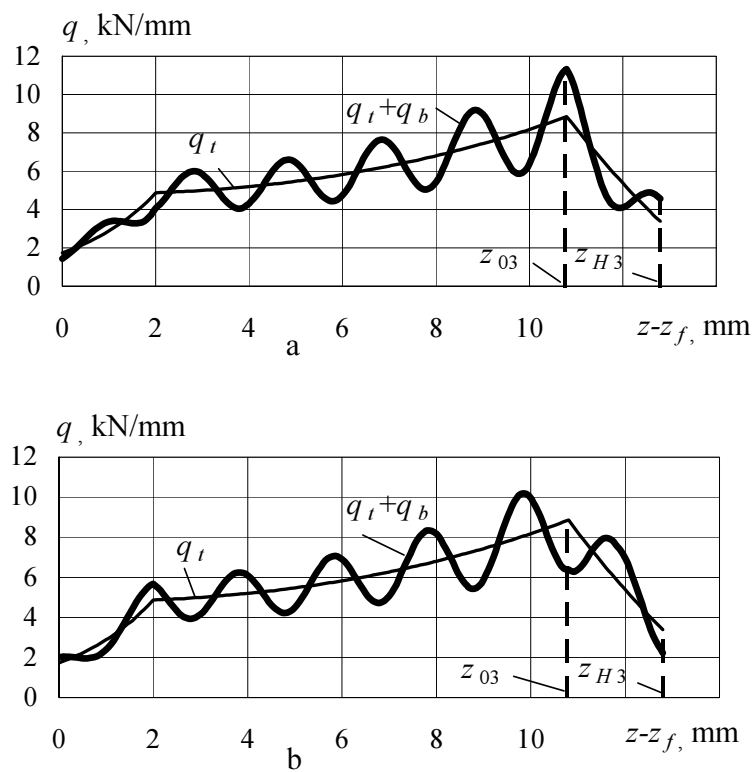

3.14 pav. Išskirstyta vijų M16×2 apkrova: sraigtinès linijos fazè $I$ (a), fazė $I V(b)$

Fig. 3.14. Load intensity of turns M $16 \times 2$ : helix phase $I(\mathrm{a})$, phase $I V(\mathrm{~b})$

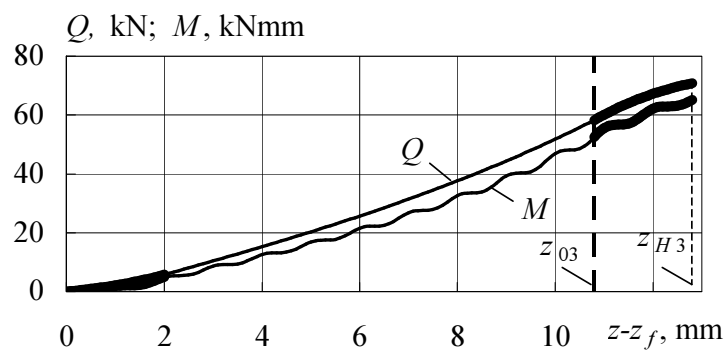

3.15 pav. Smeigès skerspjūvio ašinė vidinè jèga ir vidinis lenkimo momentas

Fig. 3.15. Internal axial force and internal bending moment of the stud cross-sections

3.14 ir 3.16 paveiksluose matyti, kad maksimalios vijų apkrovos $q_{t}(z)$ ir $q_{b}(z)$, atsirandančios dèl jungties íveržimo ir lenkimo, gali susidaryti tame pačiame jungties skerspjūvyje (3.17 a pav.) arba skirtinguose jos skerspjūviuose (3.14 b pav., 3.16 pav.). Tai priklauso nuo sraigtinès linijos išsidèstymo (fazès) lenkimo plokštumos atžvilgiu. Nuo šio faktoriaus priklauso ir jungties skerspjū- 
vio vieta, kurioje veikia didžiausia suminè vijų apkrova $q_{t}(z)+q_{b}(z)$. Didžiausios vijų apkrovos $q_{t}(z)$ ir $q_{b}(z)$ kartu veikia jungties ívijos pradžioje ties koordinate $z_{03}$, kai jungties padètị lenkimo plokštumos atžvilgiu nusako sraigtinès linijos faze $I$. Šiuo atveju suminè vijų apkrova turi didžiausią reikšmę, lyginant su kitais sraigtinès linijos padèties atvejais.
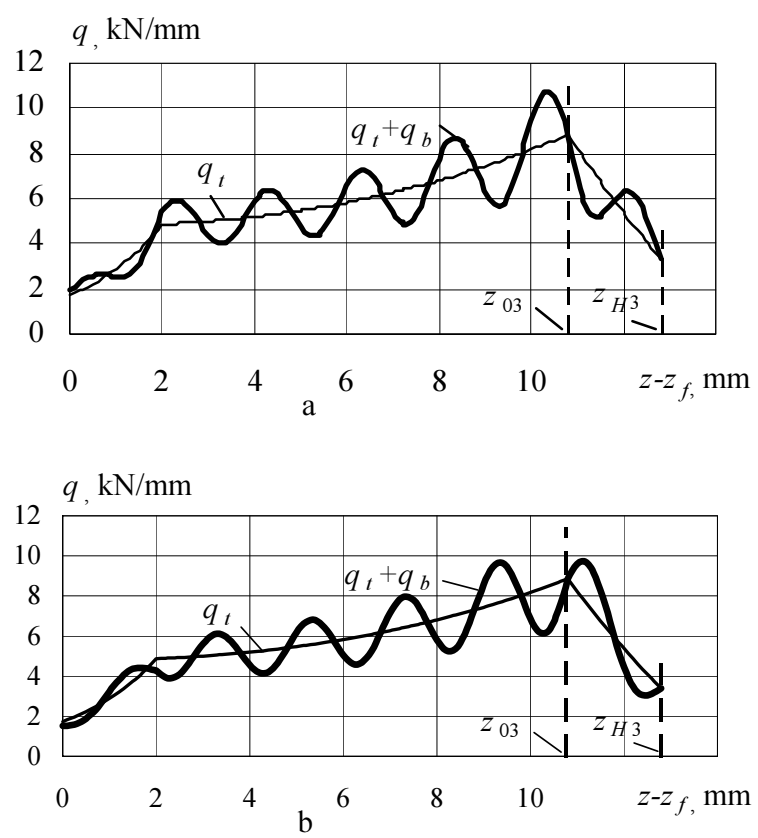

3.16 pav. Išskirstyta vijų M16×2 apkrova: sraigtinès linijos fazė $I I$ (a), fazė $I I I$ (b)

Fig. 3.16. Load intensity of turns M16×2: helix phase $I I$ (a), phase $I I I(b)$

Mažiausią suminès vijų apkrovos $q_{t}(z)+q_{b}(z)$ reikšmę jungtis turi, kai jungties padètị lenkimo plokštumos atžvilgiu nusako vijų sraigtinès linijos fazè III. Ši reikšmė lyginant su maksimalia reikšme, kurią turi jungtis su $I$-mos fazès viju sraigtine linija, yra $12 \%$ mažesnè.

3.15 paveiksle parodyta, kad vidinè ašinè jèga, atsirandanti dèl įveržimo, ir vidinis lenkimo momentas, kurie veikia visų trijų ruožų jungties skerspjūviuose, palaipsniui didèja, artejant prie veržlès atramos (prie $z_{\mathrm{H} 3}$ ). Esant ịvairioms sriegio sraigtinès linijos fazèms, lenkimo momento $M(z)$ reikšmès svyruoja, išlaikydamos tą pati didejjimo désningumą, ir išlieka tarpusavyje labai artimos. 


\subsubsection{Vietinių itempių pasiskirstymas smeigès sriegyje}

Atominès energetikos i̇rengimų stiprumo skaičiavimo normos (RF normos 1989) itempių koncentracijos zonose ciklinị stiprumą įvertina pagal vietinius sąlyginius tampriuosius itempius $\sigma^{*}$.

3.1 paveiksle parodyta, kad vietinių itempių didumas smeigès sriegio įduboje ivveržtos ir lenkiamos jungties atveju priklauso nuo iražžų $Q_{t}(z)$ bei $M(z)$ ir nuo vijos apkrovų $q_{t}(z)$ bei $q_{b}(z)$. Šiu ịrąžu ir vijų apkrovų didumą lemia išorinès apkrovos pasiskirstymas jungties sriegyje. Vietiniams itempiams skaičiuoti remiantis pradiniais duomenimis, nustatomais iš apkrovų pasiskirstymo vijose, tiksliau įvertinami visi faktoriai, kurie daro įtaką vietinių itempių didumui. Mažesnes galimybes tokiems faktoriams įvertinti turi tos metodikos, kuriose vietiniai itempiai apskaičiuojami pagal nominalius smeigès ittempius, taikant vieną bendrą itempių koncentracijos koeficienta.

Smeigei, kurios skerspjūvyje $z$ veikia ašinè jèga $Q_{t}(z)$ ir vijos apkrova $q_{t}(z)$, maksimalūs vietiniai sąlyginiai tamprieji itempiai sriegio įdubos kontūre apskaičiuojami pagal Machutovo formulę (Machutov et al. 1987), kuri išreiškia tokią sumą

$$
\sigma_{t}^{*}(z)=K_{t, m} p(z)+K_{t, 0} \sigma_{t, \text { nom }},
$$

čia $K_{t, m}$ - įtempių koncentracijų koeficientas, ivvertinantis vietinès vijos apkrovos poveiki, $K_{t, 0}$ - i̇tempių koncentracijų koeficientas, i̇vertinantis smeigès šerdies nominalių ašinių itempių poveiki, $p(z)$ - slègis sukibusių vijų kontakto plote, $\sigma_{t, n o m}-$ nominalūs ašiniai itempiai smeigès šerdyje.

Detali formulès (3.85) išraiška yra tokia:

$$
\sigma_{t}^{*}(z)=K_{t, m} \frac{q_{t}(z) \cdot P}{f}+K_{t, 0} \frac{Q_{t}(z)}{A_{s}},
$$

čia $f$ - vijos kontakto paviršiaus projekcija į statmeną smeigès ašiai plokštumą.

Tampriujų itempių koncentracijos koeficientų reikšmès yra $K_{t, m}=1,95$ ir $K_{t 0}=2$. Śios reikšmès apskaičiuotos metriniam varžto sriegiui, kurio žingsnio ir idubos spindulio santykis yra $R_{s r} / P=0,144$ (Machutov et. al. 1987).

Kai ịveržtą srieginę jungti veikia lenkimas, atsiranda dar viena vietinių itempių dedamoji $\sigma_{b}^{*}(z)$. Jų susidarymo fizinè prigimtis yra tokia pati, kokia būna veikiant smeigę ašine jèga: viena dalis atsiranda dèl vijų apkrovos, veikiančios jų kontakto plote, o kita dalis susidaro dẻl nominalių smeigès šerdị veikiančių lenkimo normalinių itempių. Todèl bendresnè vietinių itempių skaičiavimo formulè, ivvertinanti lenkimo įtaką, yra analogiška išraiškai (3.85):

$$
\sigma_{b}^{*}(z)=K_{b, m} p(z)+K_{b, 0} \sigma_{b, \text { nom }},
$$


čia $K_{b, m}$ - įtempių koncentracijų koeficientas, ịvertinantis vietinès vijos apkrovos $q_{b}(z)$ poveiki, atsirandantị dèl jungties lenkimo, $K_{t, 0}-$ itempių koncentracijų koeficientas, ivertinantis smeigès šerdyje veikiančio lenkimo momento $M(z)$ poveiki, $\sigma_{b, n o m}$ - nominalūs normaliniai lenkimo įtempiai.

Detalesnè formulès (3.87) išraiška turi toki pavidalą:

$$
\sigma_{b}^{*}(z)=K_{b, m} \frac{q_{b}(z) \cdot P}{f}+K_{b, 0} \frac{M(z)}{I_{s}} R_{v} \sin (c z),
$$

čia $R_{v} \sin (c z)$ - atstumas nuo lenkimo plokštumos iki smeigès sriegio įdubos taško, kuriam nustatomas ittempis, $R_{v}$ - smeigès šerdies spindulys, atitinkantis sriegio idubą.

Vijų apkrovos $q_{t}(z)$ ir $q_{b}(z)$, atsirandančios smeigejje dèl ašinès įveržimo jègos ir dèl lenkimo, veikia viją ta pačia kryptimi, todèl $K_{b, m}=K_{t, m}$. Itempių koncentracija, susidaranti dèl smeigès šerdyje veikiančio vidinio lenkimo momento $M(z)$, yra šiek tiek mažesnè, negu tuo atveju, kai smeigès šerdị veikia ašinè jèga $Q(z)$. Ši reiškini salygoja lenkimo nominalių normalinių ittempių gradientas. Ivertinus ši reiškini, galima parašyti taip:

$$
K_{b, 0}=K_{r} K_{t, 0},
$$

čia $K_{r}$ - vietinių įtempių sumažejjimą (dèl lenkimo) įvertinantis koeficientas.

Lenkiamų ir tempiamų strypų su žiedine ipjova teorinių koncentracijos koeficientu santykis apytiksliai yra lygus 0,9 kai žiedinès ipjovos gylis yra panašaus didumo, kokị turi sriegio profilio aukštis (Pilkey, Walter 1997). Todèl skaičiavimui imame $K_{r}=0,9$.

Taigi, visas vietinis sąlyginis tamprusis itempis smeigès sriegio įduboje yra tokio didumo:

$$
\sigma_{\Sigma}^{*}(z)=\sigma_{t}^{*}(z)+\sigma_{b}^{*}(z) .
$$

3.17 ir 3.20 paveiksluose parodytas sąlyginių vietiniu itempiu pasiskirstymas smeigeje $\mathrm{M} 16 \times 2$, kai $\sigma_{t, n o m} / R_{p 0,02}=0,6$ ir $\sigma_{b, n o m, \max } / R_{p 0,02}=0,31$. Šiuose paveiksluose linija 1 išreiškia itempius, atsirandančius dèl išorinès ašinès jègos poveikio ir apskaičiuotus pagal formulę (3.79). Linija 2 išreiškia suminius vietinius itempius, atsirandančius dèl jungties tempimo ir lenkimo (3.83). Kai jos sraigtinè linija randasi $I$ ir $I V$ fazejje (3.17 ir 3.18 pav.), tuomet jungties ivijos pradžioje ties koordinate $z_{03}$ (paveiksluose ties punktyrine linija) sriegio įdubos taškas nuo neutraliosios plokštumos yra nutolęs didžiausiu atstumu $R$ (čia $\left.\sin \left(c z_{03}\right)=1\right)$ ir maksimalūs sąlyginiai ittempiai, kurie susidaro dèl ịveržimo ir lenkimo, yra sumuojami.

3.19 ir 3.20 paveiksluose parodytas sąlyginių vietinių itempių pasiskirstymas smeigeje M16×2, kai jos sraigtine linija yra $I I$ ir III fazeje. Tuomet 
jungties ivijos pradžioje ties koordinate $z_{03}$ smeigès sriegio įdubos taškas yra neutraliojoje plokštumoje (čia $\sin \left(c z_{03}\right)=0$ ). Todèl sąlyginių vietinių ittempių, atsirandančių dèl lenkimo, čia nèra.

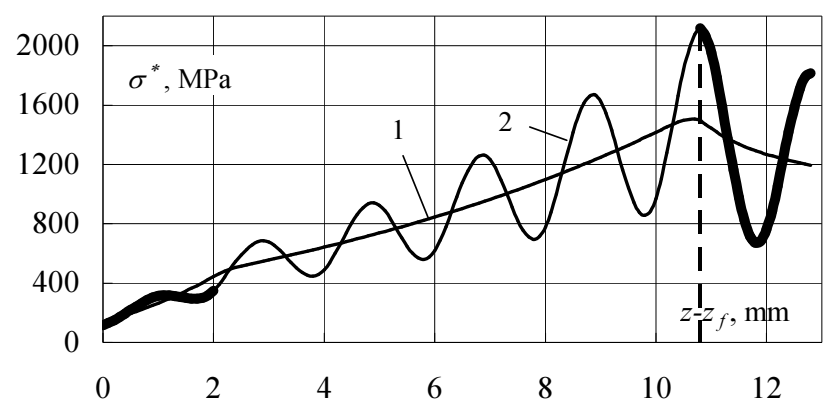

3.17 pav. Sąlyginiai itempiai smeigès sriegyje M16 $\times 2$; sraigtinès linijos padetis $I$

Fig. 3.17. Alternating elastic stresses in stud threads M16 $\times 2$ at helix phase $I$

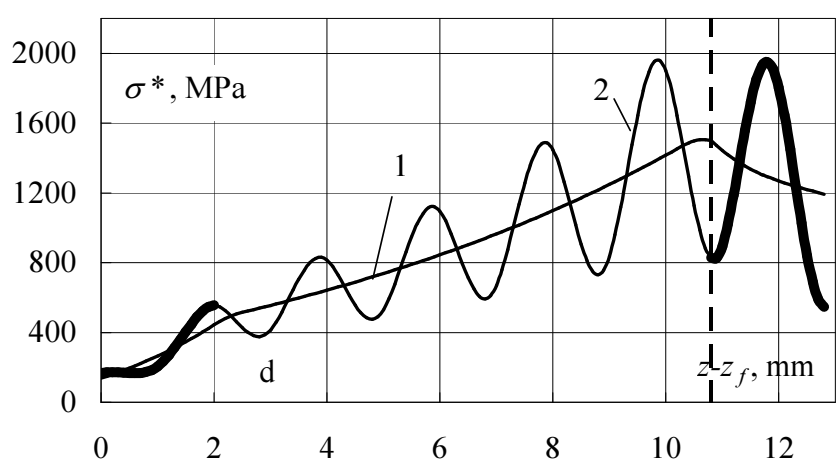

3.18 pav. Sąlyginiai įtempiai smeigès sriegyje M16 $\times 2$; sraigtinès linijos padètis $I V$

Fig. 3.18. Alternating elastic stresses in stud threads $\mathrm{M} 16 \times 2$ at helix phase $I V$

Didžiausi sąlyginiai vietiniai įtempiai smeigeje atsiranda, kai vijų sraigtinė linija yra fazejje $I$. Sie įtempiai maksimalių sąlyginių vietinių įtempių reikšmes, kurios nustatytos visiems kitiems atvejams, viršija daugiausiai $8 \%$. Maksimalios ir artimos maksimalioms vietinių ịtempių reikšmès, esant ịvairioms vijų sraigtinès linijos fazèms, susidaro skirtinguose smeigès skerspjūviuose jungties įvijos srityje ir giliau jungtyje arti skerspjūvio $z_{03}$. 


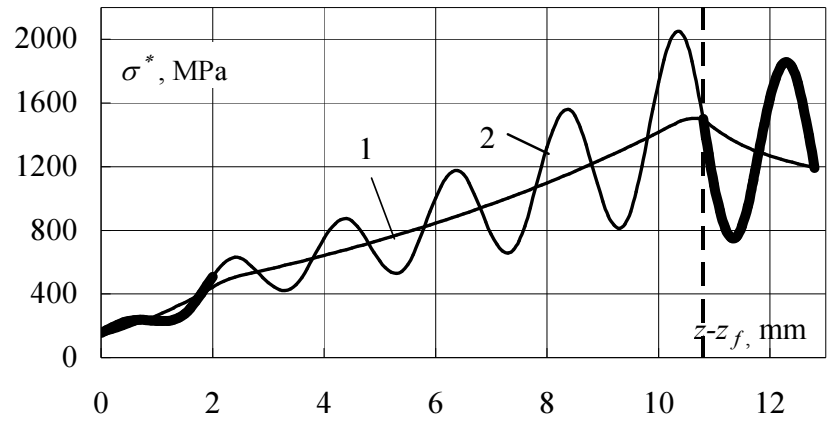

3.19 pav. Sąlyginiai įtempiai smeigès sriegyje $M 16 \times 2$; sraigtinès linijos padètis $I I$

Fig. 3.19. Alternating elastic stresses in stud threads $M 16 \times 2$ at helix phase $I I$

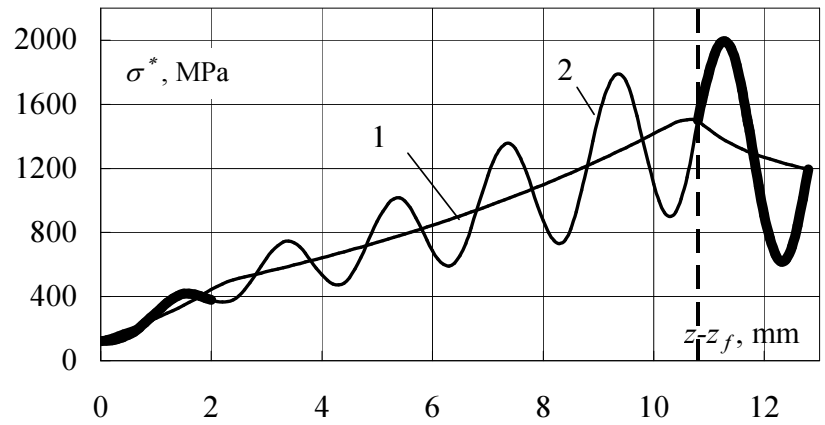

3.20 pav. Sąlyginiai įtempiai smeigès sriegyje $M 16 \times 2$; sraigtinès linijos padètis $I I I$

Fig. 3.20. Alternating elasticstresses in stud threads M16×2 at helix phase $I I I$

\subsubsection{Vietiniu itempių palyginimas su eksperimento duomenimis}

Duomenų apie apkrovų pasiskirstymą vijose po ịveržimo lenkiamoje arba necentriškai tempiamoje jungtyje, nustatytų eksperimentiškai arba BE metodu literatūroje nerasta. Straipsnyje (Burgute, Patterson 1994) iš karto pateikti eksperimentiniai duomenys apie itempių koncentraciją necentriškai tempiamoje jungtyje M24×3,5, gauti fototamprumo metodu. Šie duomenys panaudoti palyginimui su duomenimis, apskaičiuotais pagal šiame darbe sudarytą trijų ruožų srieginès jungties modeli. 


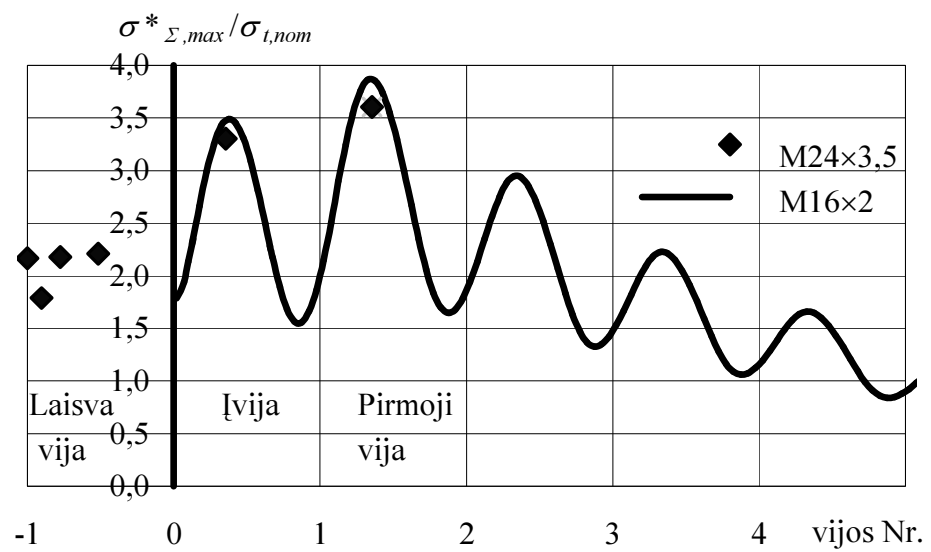

3.21 pav. Teorinių ir eksperimentinių smeigès sriegio vietinių itempių palyginimas

Fig. 3.21. Comparison of theoretical and experimental local stresses of stud thread

3.21 paveiksle parodyti duomenys, taip pat, kaip ir Burgute ir Patterson straipsnyje, yra išreikšti smeigès maksimalių vietinių tampriujų įtempių $\sigma_{\Sigma \text {,max }}^{*}$ santykiu su nominaliais tempimo itempiais $\sigma_{t, n o m}$ smeigeje. Eksperimentiniai maksimalūs vietiniai įtempiai $\sigma_{\Sigma, \max }^{*}$, išmatuoti fototamprumo metodu smeigèje M24×3,5, kuri buvo necentriškai tempiama, esant apskaičiuotam smeigès nominalių lenkimo ir temimo itempių santykiui $R_{\sigma}=\frac{\sigma_{b, \text { nom }}}{\sigma_{t, \text { nom }}}=0,48$. Toks pat šiu itempių santykis buvo taikomas ir analitiniu metodu apskaičiuojant vietinių ir nominalių smeigès itempių santykio kreivę jungčiai M16×2 (3.27 pav.). 3.27 paveiksle matyti, kad eksperimentiniai taškai išsidèstę šiek tiek žemiau kreivès, apskaičiuotos analitiniu metodu. Jungties ivvijos srityje eksperimentine santykio $\sigma_{\Sigma, \text { max }}^{*} / \sigma_{t, \text { om }}$ reikšmė yra $4,3 \%$ maženè už analitiškai nustatytą reikšmę. Pirmosios pavojingosios jungties vijos srityje eksperimentinè santykio $\sigma_{\Sigma, \max }^{*} / \sigma_{t, n o m}$ reikšmė yra 5,5 \% maženė už analitiškai nustatytą nagrinëjamo santykio reikšmę. Toks teorinès kreivès nuokrypis nuo eksperimento duomenu yra priimtinas, nes paklaida, kuri atsirastų dèl šio nuokrypio, skaičiuojant srieginès jungties ciklinį stiprumą duoda nedidelę atsargą.

Reikia nepamiršti, kad tam tikrų paklaidų šaltinis, taikant fototamprumo metodą yra realių metalinių (plieninių) ir fototampriujų medžiagų (šviesai jautrių epoksidinių dervų) mechaninių savybių skirtumas bei duomenų perskaičiavimo būtinybè. Antra vertus - apkrovos pasiskirstymo sriegyje ir itempių skaičiavimas 
yra atliktas, naudojant analitinį metodą, kuris remiasi tamprumo teorijos prielaidomis.

\subsubsection{Konstrukcinių faktorių itaka}

Pagrindiniai konstrukciniai faktoriai, kurie gali daryti itaką vietiniams ịtempiams pasiskirstyti ivveržtos ir lenkiamos smeigès sriegyje yra tokie: veržlès ilgis, sriegio žingsnis ir sriegio sraigtinès linijos padètis lenkimo plokštumos atžvilgiu. İtaka, kurią daro sraigtinès linijos padètis lenkimo plokštumos atžvilgiu išnagrinèta 3.3.2. poskyryje.

Veržlès ilgio ir sriegio žingsnio ịtaka vietinių itempių pasiskirstymui jungtyje M16×2 nagrinèta, remiantis vieno ruožo jungties skaičiavimo rezultatus, kur ivijų itakos nepaisoma.

Standartinis normalus srieginès jungties aukštis yra $H=0,8 d$. Žinoma, kad tais atvejais, kai srieginę jungtị veikia tik ašiné apkrova, naudojant ilgesnes veržles, vietinius itempius smeigès sriegyje galima sumažinti apytiksliai iki $6 \%$. Naudojant ketvirčiu trumpesnes veržles vietiniai itempiai smeiges sriegyje padidèja apie $8 \%$ (Bickford 1995). Nesukaupta tokių atvejų duomenu̧, kai i̇veržtą srieginę jungti veikia lenkimas. Veržlių ilgis, kuris skiriasi nuo normalios veržlès ilgio čia žymimas $H_{c}$.

3.22 paveiksle yra parodyta vietinių smeigès įtempiu priklausomybe nuo nagrinejjamos ir standartinès veržlès ilgių santykio $H_{c} / H$, kai $\sigma_{t, n o m} / \sigma_{0,02}=0,4$ ir $\sigma_{b, \text { nom }} / \sigma_{0,02}=0,23$. Naudojantis trumpesnèmis veržlèmis $0,75 \mathrm{H}$ ir $0,5 \mathrm{H}$, vietinis itempis smeigèje padidejja $3,8 \%$ ir $14,2 \%$, o naudojantis ilgesnèmis veržlèmis vietinis itempis smeigèje sumažeja, bet nežymiai - iki 2,9\%.

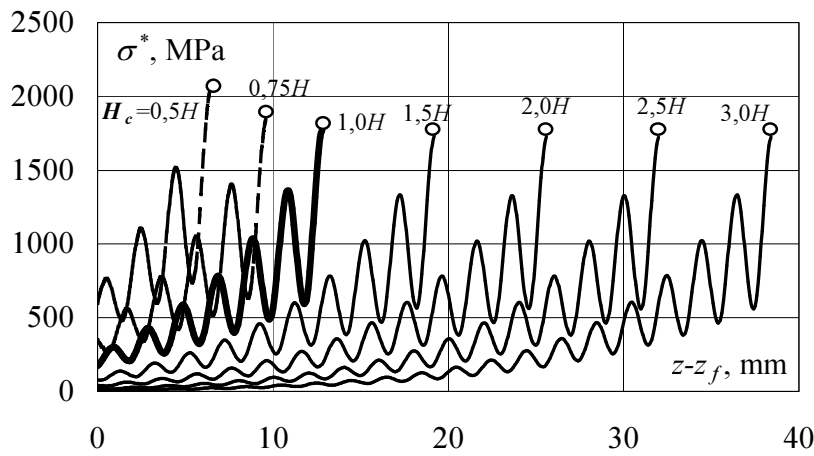

3.22 pav. Smeigès M16×2 vietinių itempių priklausomybẻ nuo veržlės ilgio

Fig. 3.22. Influence of nut length to local stresses in stud threads $M 16 \times 2$ 
3.23 paveiksle yra parodyta smeigès M16 su veržle $H=12,8 \mathrm{~mm}$ vietinių itempių priklausomybè nuo sriegio žingsnio, kai $\sigma_{t, n o m} / \sigma_{0,02}=0,55$ ir $\sigma_{b, n o m} / \sigma_{0,02}=0,34$. Smulkaus žingsnio atveju, kai $P=1 \mathrm{~mm}$, vietinis itempis smeigejje yra $21,8 \%$ mažesnis, negu stambaus žingsnio atveju, kai $P=2 \mathrm{~mm}$.

Atliktų skaičiavimų rezultatai rodo, kad veržlès ilgio padidinimas neduoda žymesnio lenkiamos smeigès vietinių itempių sumažejjimo. Vietinių itempių sumažèjimo efektas yra apie du kartus mažesnis negu tik ašine apkrova veikiamos jungties atveju. Smulkaus žingsnio naudojimas iqveržtos ir lenkiamos smeigès atveju duoda pastebimą efektą.

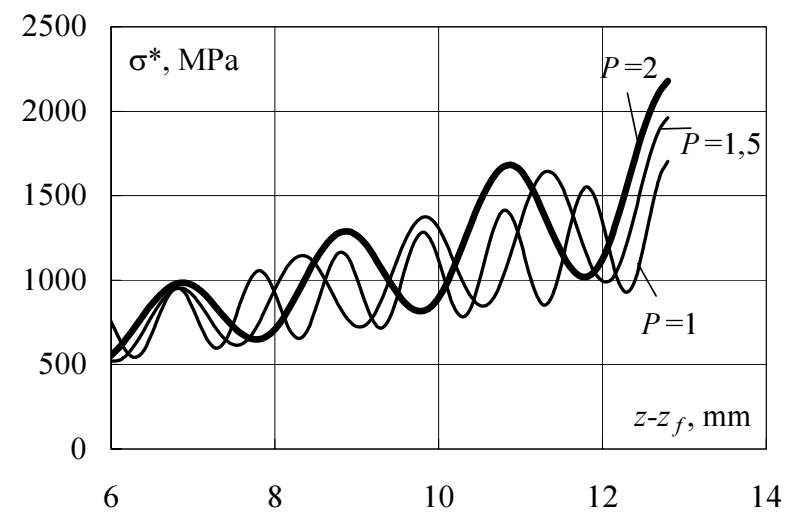

3.23 pav. Smeigès M16 vietinių įtempių priklausomybè nuo sriegio žingsnio

Fig. 3.23. Influence of thread pitch to local stresses in stud threads M16

\subsection{Daugiaruožis lenkiamos srieginès jungties modelis}

Pagal antrame skyriuje pateiktus eksperimentinius duomenis nustatyta, kad viju paslankumo reikšmé pirmą kartą jas apkraunant ir nukraunant skiriasi apie 2-2,4 kartus. Šią savybę reikia įvertinti, kai jungtis po įveržimo yra tik lenkiama. Kai iveržta jungtis patiria lenkimą i vieną pusę pirmą karta, vienoje pusejje nuo neutraliosios plokštumos sriegio pusvijų apkrova padidèja, o kitoje sumažèja - čia pusvijos nukraunamos ir ịveržimo metu igyta apkrova mažeja. Skaičiavime apkraunamoms pusvijoms reikia taikyti paslankumo reikšmę $\gamma_{f}$, o nukraunamoms pusvijoms - apie 2-2,4 kartus mažesnę paslankumo reikšmę $\gamma_{r}$. Ciklinio lenkimo atveju toki deformavimą ìveržta jungtis patiria pirmame lenkimo pusciklyje. Apkrovos pasiskirstymui vijose po ivveržimo lenkiamos jungties atveju skaičiuoti buvo sudarytas daugiaruožis srieginès jungties modelis. 


\subsubsection{Po iveržimo lenkiamos srieginès jungties diskretizavimas}

Sriegine jungtis iš pradžių yra ịveržiama. Jungti ịveržiant pirmąkart, visame sriegio perimetre vijų apkrova pirmą kartą didejja. Išilginè išskirstyta vijų apkrova $q_{t}(z)$, atsirandanti dèl ìveržimo jègos $F_{t}$ (3.24 a pav.), turi būti apskaičiuota, taikant vijų paslankumo reikšmę $\gamma_{f}$ visame vijų perimetre.

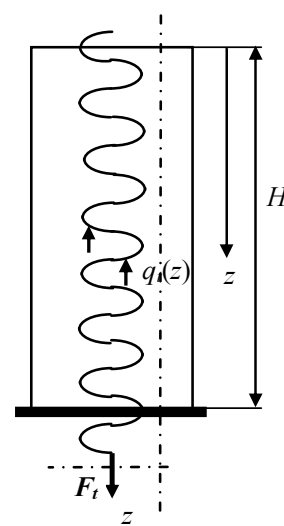

a

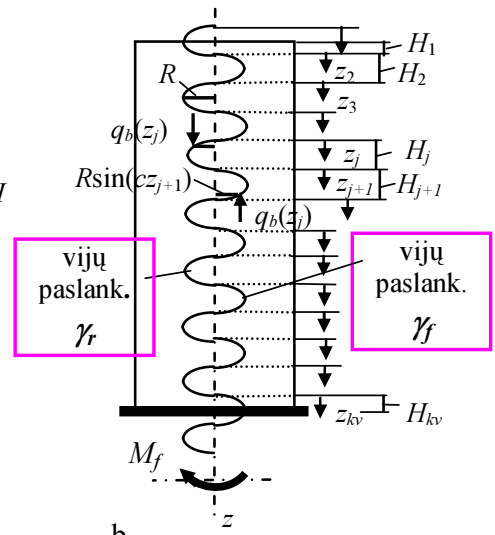

b

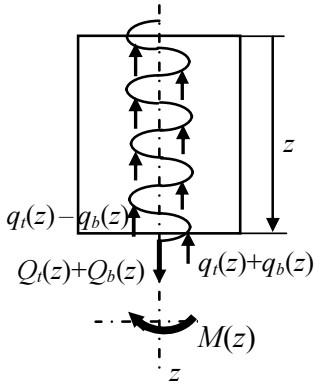

C

3.24 pav. Diskretizuota sriegine jungtis: ivveržimas (a), jungties ruožai (b), įražos (c) Fig. 3.24. Segmentated threaded joint: tightening (a), segments (b), internal forces (c)

Dèl lenkimo momento $M_{f}$ poveikio atsirandančios išskirstytos vijų apkrovos $q_{h}\left(z_{j}\right)$ skaičiavimui po įveržimo lenkiama srieginè jungtis suskaidoma i $j(j=1$, $2, \ldots . k_{v}$ ) ruožu (3.24 b pav.). Ruožus sudaro pakaitomis abiejose pusėse nuo neutraliosios plokštumos išsidèsčiusios pusvijos arba dar mažesnès jų dalys jungties galuose. Ruožuose vijų paslankumo reikšmė pakaitomis keičiasi. Apkraunamos pusvijos turi reikšmę $\gamma_{f}$, o nukraunamos $\gamma_{r}$. Atitinkamos reikšmės suteikiamos ir i̇vijų dalims, kurios yra priešingose pusèse nuo $N L$. Daugumos ruožų ilgi $H_{j}$ sudaro sriegio žingsnio pusès ilgis $P / 2$. Kraštuose esančių ruožų ilgiai lengvai nustatomi skaidant jungti. Ruožo skerspjūvio koordinatès $z_{j}$ pradžia ir pabaiga sutampa su atitinkamos pusvijos pradžia ir pabaiga, o jungties kraštuose dar gali būti ten, kur prasideda arba baigiasi ịvija.

Pusvijų ar jų dalių ilinkiai, apkrovos ir vidinis lenkimo momentas apskaičiuojami, taikant tas pačias lygtis, kurios pasitelkiamos ir trijų ruožų srieginès jungties atveju, pakaitomis jose įstatant skirtingas paslankumo reikšmes: apkraunamoms pusvijoms reikšmę $\gamma_{f}$, o nukraunamoms $-\gamma_{r}$. Ruožų, kuriuose vijos sukibusios visu profiliu, vidiniams momentams ir vijų apkrovoms apskaičiuoti reikia naudotis išraiškomis (3.32), (3.30), (3.20) ir (3.5). Ruožų, kuriuos sudaro ivijų dalys, vidiniams momentams ir vijų apkrovoms apskaičiuoti reikia pasi- 
naudoti išraiškomis (3.46), (3.44), (3.20) ir (3.5). Šių lygčių koeficientai $A_{j}, B_{j}$ ir $A_{j-1}, B_{j-1}$ daugiaruožei jungčiai nustatomi iš lygčių sistemos, kuri gaunama sulyginus tokias jungties ruožų kraštines sąlygas:

$$
\begin{gathered}
y\left(z_{j+1}=0\right)=y\left(z_{j}=H_{j}\right), \quad j=1 \ldots \ldots k_{v} \\
M\left(z_{1}=z_{f}\right)=0, \\
M\left(z_{j+1}=0\right)=M\left(z_{j}=H_{j}\right), \quad j=1 \ldots \ldots k_{v} \\
M\left(H_{k v}\right)=M_{f} .
\end{gathered}
$$

\subsubsection{Pusvijų nukrovimo itaka apkrovos pasiskirstymui}

Po įveržimo lenkiamos jungties viju apkrovos $q_{h}\left(z_{j}\right)$ buvo apskaičiuotos jungties M16 $\times 2$, pagamintos iš plieno $25 \mathrm{X} 1 \mathrm{M} \Phi$, atvejui. Veržlès ilgis yra $H=0,8 d=$ $12,8 \mathrm{~mm}$. Sraigtinès linijos padètis lenkimo plokštumos atžvilgiu nustatyta pagal fazę $I$. Todèl jungti prireikè suskaidyti į 15 ruožų. Nominalūs tempimo ir lenkimo itempiai smeigès šerdyje yra $\sigma_{t, n o m} / R_{p 0,02}=0,6$ ir atitinkamai $\sigma_{b, \text { nom, max }} / R_{p 0,02}=$ 0,31 . Vijų apkrova $q_{t}\left(z_{j}\right)$, atsiradusi dèl įveržimo, apskaičiuota pagal 3.2.6. skyriuje pateiktas formules. 3.25 paveiksle yra pateiktas palyginimas skaičiavimo
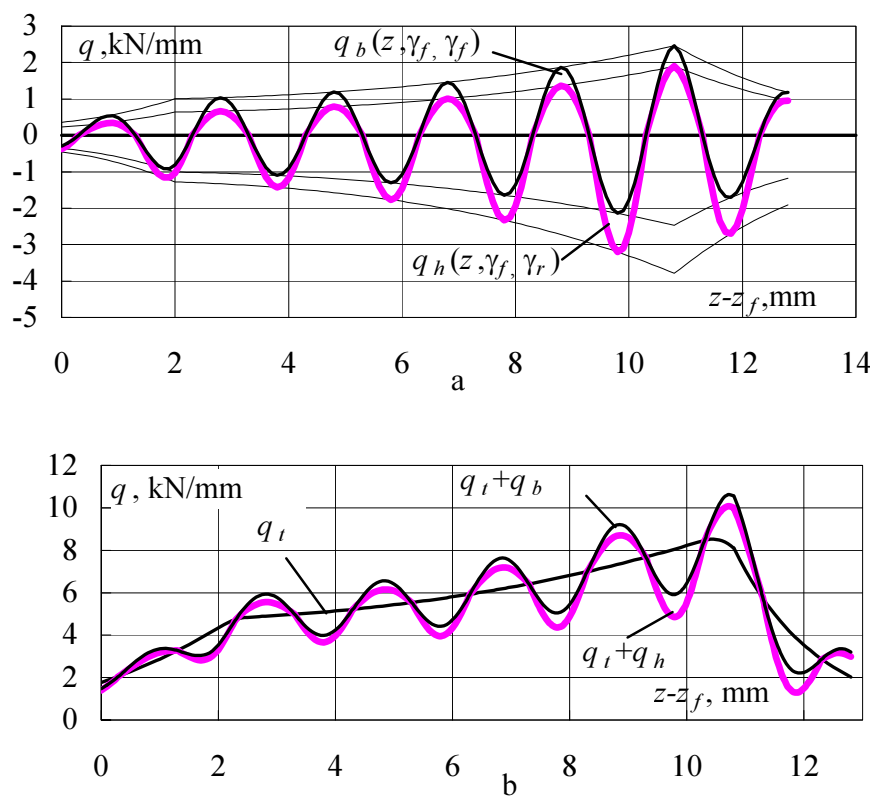

3.25 pav. Sriegio vijų apkrovos: lenkimo jungtis (a), jungties lenkimas ir tempimas (b)

Fig. 3.25. Loads of joint threads: bent joint (a), tension and bending of jodint (b) 
rezultatų, gautų taikant daugiaruoži ir trijų ruožų jungties modelius. Taikant trijų ruožų modeli buvo nustatyta vijų apkrova $q_{b}(z)$, suderinus, kad veikiant necentriniam tempimui, ašinès jègos didumas pasiektų tą pačią reikšmę, kurią daugiaruožè jungtis turi dèl ịveržimo.

Lyginant skaičiavimo rezultatus reikia prisiminti, kad necentrinio tempimo atveju abiejose jungties pusėse visu profiliu sukibusių vijų paslankumo reikšmès yra vienodos $-\gamma_{f}$, o lenkiant po ivveržimo skirtingos $-\gamma_{f}$ ir $\gamma_{r}$. Ivijų viduryje atitinkamai - 1,67 $\gamma_{f}$, o lenkiant po ivveržimo - 1,67 $\gamma_{f}$ ir 1,67 $\gamma_{r}$.

Pagal 3.25 a paveiksle pateiktus rezultatus, nustatyta, kad viju apkrovos $q_{h}$, atsiradusios pavojingoje jungties srityje lenkiant ją po įveržimo, vienoje jungties pusèje yra 14,2 \% mažesnès, o kitoje $48,3 \%$ didesnès už vijų apkrovas $q_{b}$, atsiradusias tik dèl lenkimo jungties necentrinio tempimo atveju.

Naudojantis 3.25 b paveiksle pateiktais rezultatais, kur ịvertinta ir dèl ašinès jègos atsiradusi vijų apkrova $q_{t}$, nustatyta, kad po įveržimo lenkiamos jungties atveju, vienoje pusejje nuo $N L$ suminè pusvijų apkrova $q_{t}+q_{h}$ yra mažesnè apie $6 \%$, o kitoje $-11 \%$, lyginant su apkrovomis $q_{t}+q_{b}$, kurios veikia jungties necentrinio tempimo atveju.

\subsection{Trečiojo skyriaus išvados}

1. Lenkiamos srieginès jungties būviui apibūdinti sudaryta deformavimo schema ir pasiūlytas matematinis modelis susieja vijų ịlinkius su veržlès ir smeigès skerspjūvių kampiniais poslinkiais poslinkių darnos lygtimi geometriškai, taip pat ir matematiškai:

a) kai sriegio vijos yra sukibusios visu profiliu,

b) kai sriegio vijos yra sukibusios ne visu profiliu.

2. Diferencialinių lygčių sprendinių - vijų apkrovų ir vidinių lenkimo momentų - skaitinès reikšmès, nustatytos analitiniu ir Rungès - Kutto metodais visame srieginès jungties ilgyje, skiriasi nežymiai, ne daugiau kaip $1 \%$.

3. Lyginant necentriškai tempiamos smeigès sriegio maksimaliu vietiniu itempių reikšmes, apskaičiuotas taikant sudarytą analitini modeli, su eksperimentinėmis reikšmėmis, gautomis fototamprumo metodu (Burguete ir Patterson, 1994), nustatytas šių reikšmių skirtumas sudaro apie $5 \%$.

4. Sudarytas trijų ruožų srieginès jungties modelis yra tinkamas necentrinio apkrovimo ir nukrovimo atvejams, kai pusvijų poros, esančios priešingose jungties pusèse, deformuojamos viena kryptimi - apkraunamos arba nukraunamos ir apriešingose jungties pusèse turi tą pačią paslankumo reikšmę.

5. Daugiaruožis srieginès jungties modelis yra tinkamas ir po įveržimo lenkiamų jungčių atvejui, kai pusvijų poros, esančios priešingose jungties pusėse, deformuojamos priešingomis kryptimis ir turi skirtingus paslankumus. 
6. Skaičiavimai, atlikti naudojant sudarytus modelius jungčiai M16, pagamintai iš plieno $25 \mathrm{X} 1 \mathrm{M} \Phi$, su apkrova $\sigma_{t, n o m} / R_{p 0,02}=0,6$ ir $\sigma_{b, \text { nom, } \max } / R_{p 0,02}=0,31$ davè tokius rezultatus:

a) nustatyta, kad vijų apkrovos $q_{h}$, atsiradusios pavojingoje jungties srityje lenkiant ją po ivveržimo, vienoje jungties puseje yra 14,2 \% mažesnès, o kitoje $48,3 \%$ didesnès už vijų apkrovas $q_{b}$, atsiradusias tik dèl lenkimo jungties necentrinio tempimo atveju.

b) nustatyta, kad po iveržimo lenkiamos jungties atveju, vienoje pusèje nuo $N L$ suminè pusvijų apkrova $q_{t}+q_{h}$ yra mažesnè apie $6 \%$, o kitoje $-11 \%$, lyginant su apkrovomis $q_{t}+q_{b}$, kurios veikia jungties necentrinio tempimo atveju.

c) maksimalios vietinių itempių reikšmès, esant ịvairioms vijų sraigtinès linijos fazėms, susidaro skirtinguose lenkiamos smeigès skerspjūviuose. Didžiausių vietinių itempių smeigeje atsiranda, kai vijų sraigtinè linija yra fazèje $I$, ir jie daugiausiai $8 \%$ viršija vietinių įtempių reikšmes, nustatytas visiems kitiems atvejams.

d) smulkaus žingsnio atveju, kai $P=1 \mathrm{~mm}$, vietinis itempis smeigeje yra $21,8 \%$ mažesnis, negu stambaus žingsnio atveju, kai $P=2 \mathrm{~mm}$. 



\section{4}

\section{Cikliškai lenkiamu srieginių jungčių ilgaamžiškumas}

Šiame skyriuje nustatyti smeigès lenkimo įrąžos, vijų apkrovos bei vietinių itempių ciklo parametrai, ivvertinant viju paslankumo savybių itaką apkrovos sriegio vijose pasiskirstymui. Remiantis palyginimu su eksperimentiniais rezultatais, patikrinta galimybè taikyti lenkimo apkrovos pasiskirstymo sriegyje duomenis modifikuoto norminio mažaciklio ilgaamžiškumo skaičiavimo metodikoje. Šiam palyginimui atlikti skaičiavimai pagal norminę metodiką (RF normos 1989), nevertinant apkrovos pasiskirstymo vijose, ir skaičiavimai pagal modifikuotą norminę metodika, anksčiau patikrinta, naudojant cikliškai tempiamų srieginių jungčių ilgaamžiškumo eksperimentinius duomenis. Skyriuje pateiktas po iveržimo lenkiamų srieginių jungčių M16 mažaciklio ilgaamžiškumo skaičiavimo duomenų palyginimas su eksperimentiniais rezultatais, anksčiau gautais VGTU stiprumo mechanikos laboratorijoje. Skyriaus medžiaga paskelbta atoriaus straipsniuose (Juchnevičius, Krenevičius 2011a), (Ž. Juchnevičius, A. Krenevičius 2011b). 


\subsection{Viju paslankumo savybių itaka}

Antrame skyriuje pateikti eksperimentiniai viju poros tempimo bandymai parode, kad vijų poros paslankumo reikšmè apkraunant pirmą kartą yra apie 2-2,4 kartus didesnè už tą, kurią ji turi nukraunant ir po to pakartotinai apkraunantnukraunant. I šią viju paslankumo savybę turi būti atsižvelgta, nustatant visų smeigę veikiančių apkrovų ciklo parametrus, kai nagrinejjamas ciklinis stiprumas.

Pagal vijų deformavimo krypties požymius lenkiamos jungties apkrovimo būvių klasifikacija pateikta žemiau.

1. Iveržimas - centriškas arba necentriškas tempimas. Necentriškas tempimas iveržiant galimas tik toks, kai abiejose pusèse nuo NL (NL - atsižvelgiant tik lenkima) suminè vijų apkrova didejja.

\section{Necentrinis tempimas pirmajame pusciklyje:}

2a, kai abiejose pusèse nuo NL suminè pusvijų apkrova didejja (skirtingu greičiu) - tinka trijų ruožų ir daugiaruožis modeliai;

$\mathbf{2 b}$, kai visos pusvijos, esančios vienoje pusèje nuo NL, suminè apkrova didejja, o kitoje mažèja - tinka daugiaruožis modelis;

2c, kai mažesnèje pusvijos dalyje, esančioje vienoje pusèje nuo NL, suminè apkrova mažejja, o likusioje vijos dalyje didèja; - tinka daugiaruožis modelis su papildomais nežinomaisiais $z_{0 j}$ ir $z_{H j}$ (disertacijoje šis atvejis nenagrinèjamas).

\section{Lenkimas po ịveržimo pirmajame pusciklyje:}

3a, vienpusis ciklinis lenkimas - tinka daugiaruožis modelis;

$\mathbf{3 b}$, dvipusis simetrinis ciklinis lenkimas - tinka daugiaruožis modelis;

3c, dvipusis asimetrinis ciklinis lenkimas - tinka daugiaruožis modelis.

\section{Kartotinis lenkimas:}

4a, veikiant necentriniam cikliniam tempimui;

$\mathbf{4 b}$, veikiant cikliniam lenkimui po įveržimo;

4a ir $\mathbf{4 b}$ atvejams tinka trijų ruožų ir daugiaruožis modeliai.

Tais atvejais, kai apkrovimo būvių klasifikacijoje nurodyti trijų ruožų ir daugiaruožis modeliai, racionaliau yra naudoti trijų ruožų modelį dèl mažesnès matematinių veiksmų apimties. Visais atvejais ten, kur suminé vijų apkrova didejja pirmą karta, imama vijų poros paslankumo reikšmė yra $\gamma_{f}$. Visais kitais atvejais reikia vartoti reikšmę $\gamma_{r}$.

Kai sriegine jungtis necentriškai tempiama pirmą kartą - tempiama ir lenkiama pirmame apkrovimo pusciklyje - tuomet abiejose pusèse nuo neutraliosios plokštumos sriegio pusvijų apkrova palaipsniui didèja, bet skirtingu greičiu. Abiejose jungties pusèse pusvijuc porų paslankumas yra vienodas, o jo reikšmé, pirmą kartą apkraunant, yra $\gamma_{f}$. 
Kai îveržta jungtis pirmą kartą patiria tik lenkimą, tuomet vienoje pusèje nuo neutraliosios plokštumos sriegio pusvijų apkrova padideja ir jų deformavimą lemia paslankumas, kurio reikšmė yra $\gamma_{f}$. Kitoje pusėje pusvijų paslankumas $\gamma_{r}$ yra apie du kartus mažesnis, nes čia jos nukraunamos. Toki apkrovimą iveržta jungtis patiria pirmame lenkimo pusciklyje.

Kai vyksta ivveržtos jungties ciklinis lenkimas arba necentrinis ciklinis tempimas, tuomet abiejose pusèse nuo neutraliosios plokštumos pusvijos cikliškai apkraunamos arba nukraunamos. Šiuo atveju, nusistovejjusiame apkrovimo cikle, abiejose jungties pusėse pusvijų porų paslankumo reikšmè yra vienoda $-\gamma_{r}$.

Sriegio vijų paslankumo savybių itaka, atspindi vijų ilinkių ir vijų apkrovų pasiskirstymo jungtyje M16 $\times 2$ grafikai (4.1 pav.). Skaičiavimui buvo panaudotos tokios išorinès apkrovos, kad smeigès nominalaus maksimalaus itempio santykis su medžiagos takumo itempiu, kuris susidaro dèl jègos jègos $F_{t}$ poveikio, būtų $\sigma_{t, \text { nom, } \max } / R_{p 0,02}=0,6$, o smeigès nominalaus maksimalaus itempio santykis su medžiagos takumo ittempiu, kuris susidaro dèl lenkimo momento $M_{f}$ poveikio, bütų $\sigma_{b, n o m, \max } / R_{p 0,02}=0,31$.

4.1 a paveiksle jungties A ir B pusėms parodyti tokie viju illinkių amplitudžių funkcijų grafikai: $y_{r}(z)$ - iveržtai jungčiai nusistovejjusio lenkimo ciklo atvejui, $y_{h}(z)$ ir $y_{h^{*}}(z)$ - ivveržtai jungčiai, kuri lenkiama pirmajame pusciklyje, $y(z)$ - pirmą kartą necentriškai tempiamai jungčiai (tempiamai ir lenkiamai pirmajame pusciklyje). Visos vijų ilinkių amplitudžių funkcijos, esančios A ir B jungties pusèse, turi lygiagretaus išsidèstymo pobūdị ir yra simetriškos. Tai atitinka tampruji smeigès šerdies ir veržlès sienelès deformavimą, atsirandantị lenkiant. Smeigès šerdies ir veržlès sienelès sluoksniai jungties A ir B pusèse turi simetriškas - vienodo didumo deformacijas ir poslinkius su priešingais ženklais. Simetriškai besideformuodamos šios detalès verčia ir vijas deformuotis simetriškai, net ir tuo atveju, kai vijų paslankumas abiejose jungties pusèse yra skirtingas $\left(y_{h}(z)=-y_{h^{*}}(z)\right)$.

4.1 a paveiksle parodytu grafikų jungties A pusei palyginimas parodè, kad vijų illinkių amplitudžių funkcijos reikšmè $y_{r}\left(z=z_{c}\right)$ ties veržlès atrama, nustatyta iveržtai jungčiai nusistovẻjusio lenkimo ciklo atvejui, yra 0,86 karto mažesnè už reikšmę $y_{h}\left(z=z_{c}\right)$, nustatytą atvejui, kai ịveržta jungtis lenkiama pirmajame pusciklyje. Vijų įlinkių amplitudžių funkcijos reikšmè $y\left(z=z_{c}\right)$, nustatytą pirmą kartą necentriškai tempiamos jungties atvejui, yra didesnè už $y_{h}\left(z=z_{c}\right) 1,25$ karto.

Jungties B pusėje, kur vijų ịlinkiai neigiami, vijų ịlinkių amplitudžių funkcijos yra tokio pat didumo, kaip jungties A puseje.

$4.1 \mathrm{~b}$ paveiksle jungties A ir B pusėms parodyti tokie vijų apkrovų amplitudžių funkcijų grafikai: $u_{r}(z)$ - iveržtai jungčiai nusistovejjusio lenkimo ciklo atvejui, $u_{h}(z)$ ir $u_{h^{*}}(z)$ - iveržtai jungčiai, kuri lenkiama pirmajame pusciklyje, $u(z)-$ pirmą kartą necentriškai tempiamai jungčiai. Šių grafikų išsidèstymą lemia vijų porų paslankumo reikšmès, kurias vijos turi jungties A ir B pusèse, nepamirštant $\operatorname{kad} \gamma_{f}>\gamma_{r}$. 


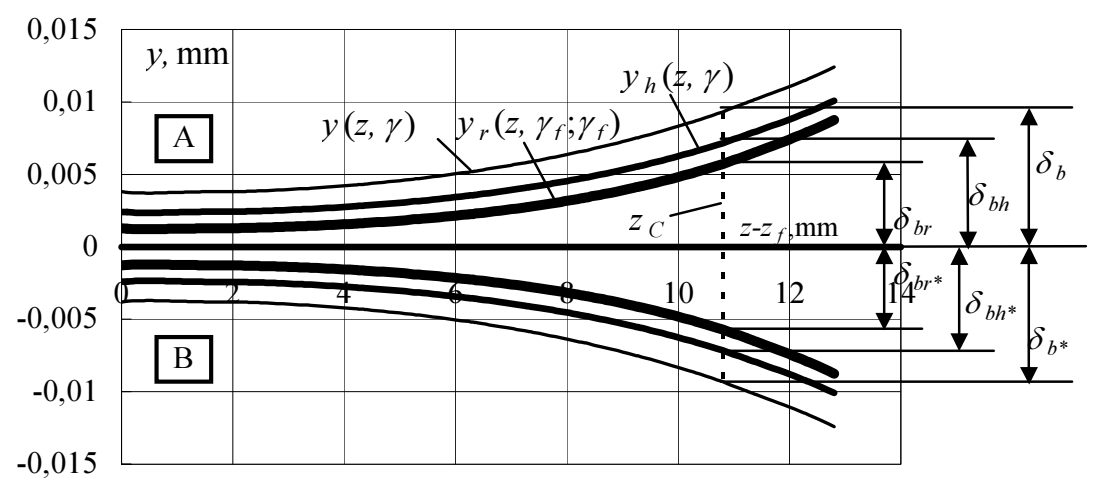

a

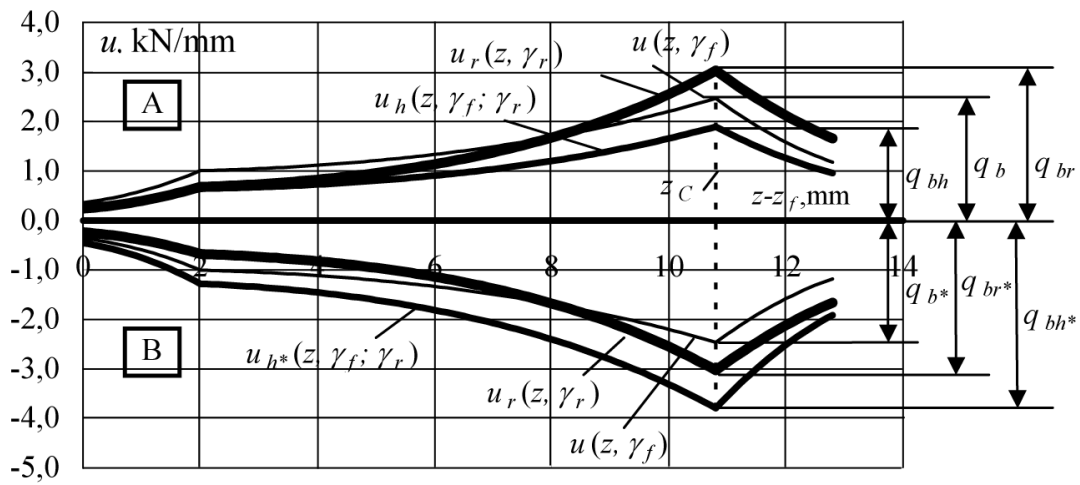

b

4.1 pav. Jungties M16×2 vijų ilinkių (a) ir vijų apkrovų (b) amplitudžių funkcijos

Fig. 4.1. Amplitude functions of turn pair loads (a) and of deflections (b)

Kai abiejose jungties pusėse vijų paslankumas vienodas, vijų apkrovų amplitudžių funkcijų grafikai $\left(u_{r}(z)\right.$ ir $\left.u(z)\right)$ yra simetriški. Tais atvejais, kai abiejose jungties pusėse vijų paslankumas nèra vienodas, vijų apkrovų amplitudžių funkcijų grafikai $\left(u_{h}(z)\right.$ ir $\left.u_{h^{*}}(z)\right)$ išsidèsto nesimetriškai. Pavojingoje jungties srityje, ties veržlès atrama, vijų apkrovų amplitudžių funkcijų reikšmès A pusèje išsidèsto tokia tvarka: $u_{r}\left(z_{c}\right)>u\left(z_{c}\right)>u_{h}\left(z_{c}\right)$. Jungties B puseje atitinkamų reikšmių absoliutiniai dydžiai sudaro seką: $u_{h} *\left(z_{c}\right)>u_{r}\left(z_{c}\right)>u\left(z_{c}\right)$. Kadangi funkcijos $u_{h}(z)$ ir $u_{h} *(z)$ aprašo vijų būvị tik pirmajame lenkimo pusciklyje ir $u_{r}(z)>u(z)$, tai tikrinant ciklini jungties stiprumą pagal nusistovèjusi ciklą, vijų apkrovos amplitudę reikia skaičiuoti taikant funkciją funkciją $u_{r}\left(z_{c}\right)$ ir vijų paslankumo reikšmę $\gamma_{r}$ abiem jungties pusėms. Turètume pastebėti, kad cikliniam skaičiavimui abiejose 
jungties pusèse vartojant vijų paslankumo reikšmę $\gamma_{f}$ ir vijų apkrovos amplitudès funkcija $u(z)$, atsiranda žymi paklaida. Ties jungties atrama $u\left(z_{c}\right)$ reikšmé yra $27 \%$ mažesnè už $u_{r}\left(z_{c}\right)$ reikšmę.

$4.1 \mathrm{~b}$ paveikslèlyje matyti, kad jungtis, kuri po įveržimo lenkiama pirmą kartą, tempiamoje pusejje (jungties pusèje A) turi gerokai mažesnes vijų apkrovų reikšmes, lyginant su vijų apkrovomis jungties ,gniuždomoje“ pusèje (jungties puseje B). Sių apkrovų santykis yra tokio pat didumo, koki turi paslankumu $\gamma_{f}$ ir $\gamma_{r}$ santykis. Kadangi $\gamma_{f} / \gamma_{r} \approx 2$, tai $u_{h^{*}}\left(z_{c}\right) / u_{h}\left(z_{c}\right) \approx 2$. Šie rezultatai leidžia manyti, kad jungties skerspjūviuose ir jungties gale atsiranda papildoma ašinè jèga $Q_{b}\left(z_{j}\right)$, kuri veikia priešinga įveržimui kryptimi ir ji mažina. Formulès šios jègos ir jos prieauglio ruože $j$ skaičiavimui yra gautos tokiu būdu:

$$
\begin{gathered}
\Delta Q_{b}\left(z_{j}\right)=\int_{0}^{z_{j}} q_{b}\left(z_{j}\right) d z_{j}=\frac{1}{\gamma} \int_{0}^{z_{j}}\left[A_{j} \sinh \left(n_{j} z_{j}\right)+B_{j} \cosh \left(n_{j} z_{j}\right)\right] \cdot \sin \left(c z_{j}\right) d z_{j}= \\
=\frac{A_{j}}{\gamma\left(n_{j}^{2}+c^{2}\right)}\left[n_{j} \cosh \left(n_{j} z_{j}\right) \sin \left(c z_{j}\right)-c \cdot \sinh \left(n_{j} z_{j}\right) \cos \left(c z_{j}\right)\right]+ \\
+\frac{B_{j}}{\gamma\left(n_{j}^{2}+c^{2}\right)}\left[n_{j} \sinh \left(n_{j} z_{j}\right) \sin \left(c z_{j}\right)-c \cdot \cosh \left(n_{j} z_{j}\right) \cos \left(c z_{j}\right)\right], \\
Q_{b}\left(z_{j}\right)=\sum_{j=1}^{j-1} \Delta Q_{b}\left(H_{j}\right)+\Delta Q_{b}\left(z_{j}\right) .
\end{gathered}
$$

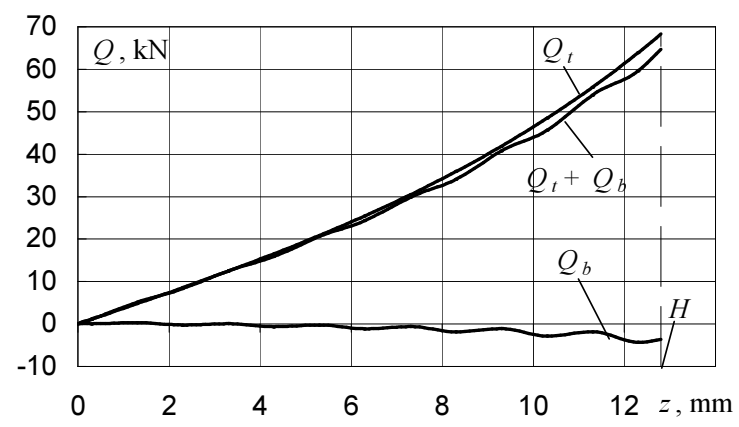

4.2 pav. Iveržimo jègos sumažèjimas dèl lenkimo jungtyje M16 $\times 2$

Fig. 4.2. Decrease of the force of tightening due to bending in joint $M 16 \times 2$

Apkrovus iveržtą jungti M16×2 lenkimu ivveržimo jèga ties koordinate $z=H$ sumažeja apie $5 \%$ (pav. 4.2). 


\subsection{Sriegio viju ciklinio apkrovimo schemos}

4.3-4.7 paveiksluose parodytos viju poros apkrovimo schemos jungties lenkimo pradžioje ir pasikartojančio lenkimo cikle. 4.1 paveiksle ir visuose šio skyriaus paveiksluose vijų illinkių ir vijų apkrovų žymenys atitinka 4.1 paveiksle naudojamus žymejjimus. Srieginès jungties dalis, esanti vienoje neutraliosios plokštumos puseje, kurioje vyksta vijų apkrovos padidejimas 1-ame ciklo ketvirtyje (paveiksluose $-1 k c$ ) arba 1-ame pusciklyje (paveiksluose - $1 p c$ ), pažymèta simboliu A. Kita pusè pažymèta simboliu B.
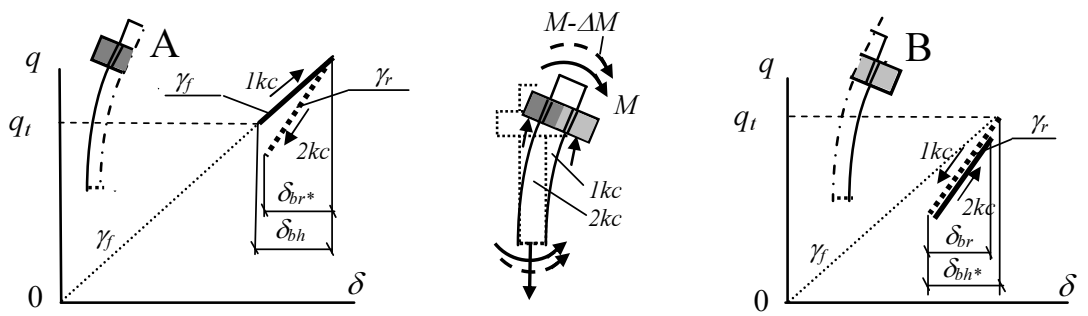

a
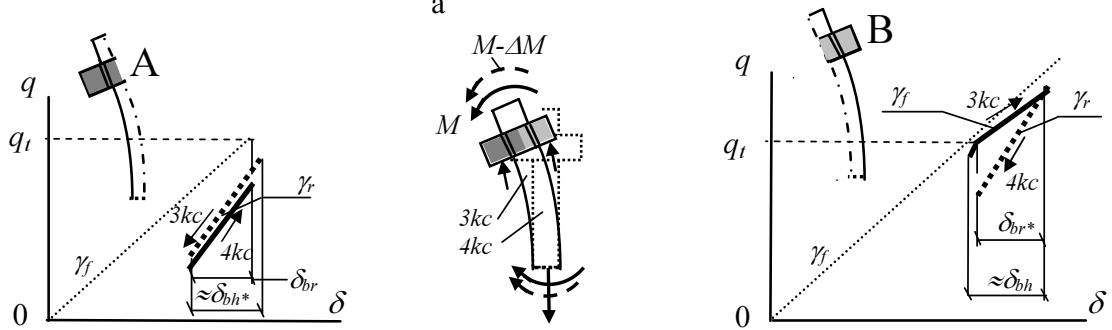

b

4.3 pav. Srieginės jungties dvipusis lenkimas: vijų poros apkrovimas pirmajame (a) ir antrajame (b) lenkimo pusciklyje

Fig. 4.3. Two-side bending of the threaded connection: turn pair loading in the first (a) and in the second (b) bending semicycle
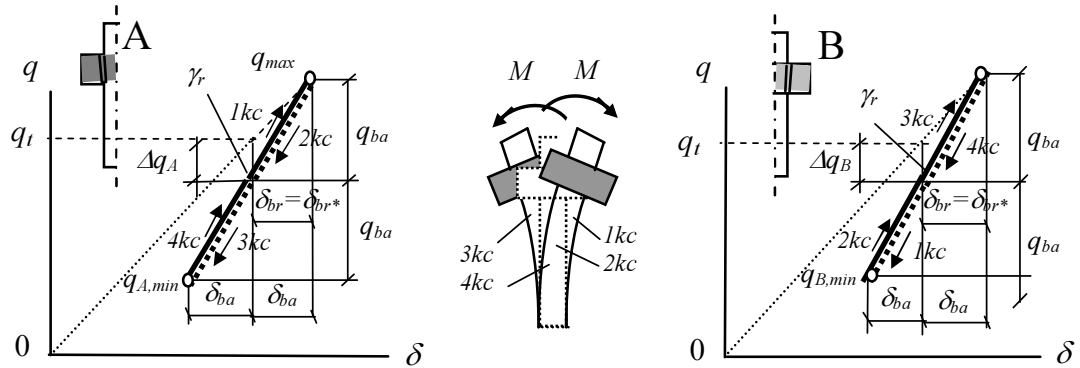

4.4 pav. Jungties vijų poros apkrovimas pasikartojančiame dvipusio lenkimo cikle

Fig. 4.4. Turn pair loading in the repetitive two-sided bending cycle of joint 

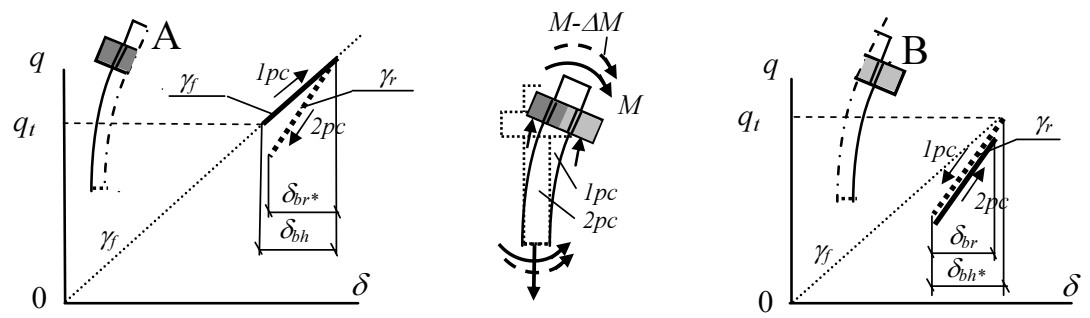

4.5 pav. Srieginès jungties vienpusis lenkimas: vijų poros apkrovimas pirmajame ir antrajame lenkimo pusciklyje

Fig. 4.5. Single-side bending of the threaded connection: turn pair loading in the first and in the second bending semicycle
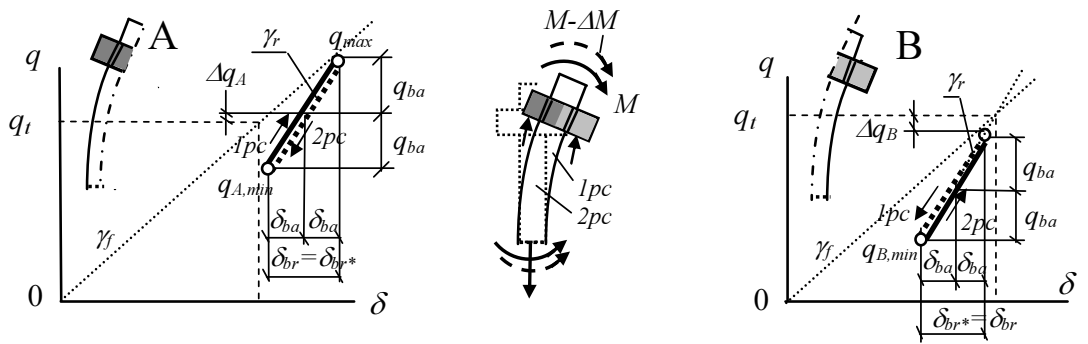

4.6 pav. Jungties vijų poros apkrovimas pasikartojančiame vienpusio lenkimo cikle Fig. 4.6. Turn pair loading in the repetitive single-sided bending cycle of joint

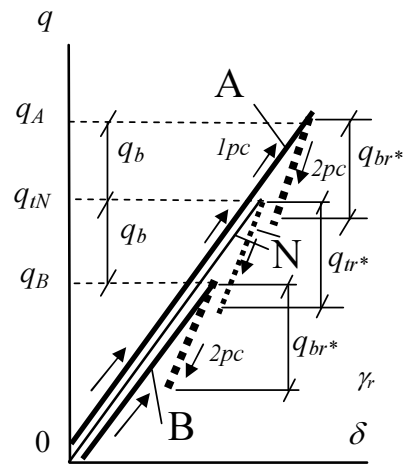

a

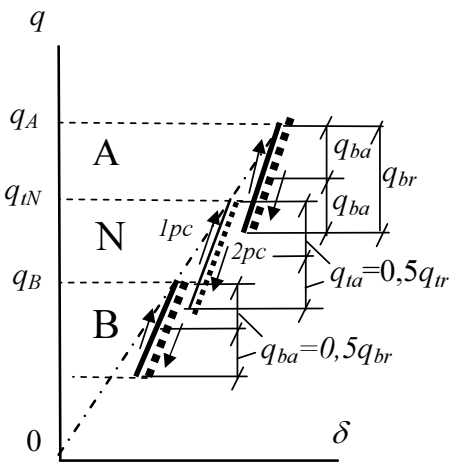

$\mathrm{b}$

4.7 pav. Srieginès jungties necentrinis tempimas: vijų poros pirmas apkrovimo ciklas (a), viju poros pasikartojantis apkrovimo ciklas (b) Fig. 4.7. Eccentric tension of threaded connection: first loading cycle of the turn pair(a), repetitive loading cycle of the turn pair (b) 
4.7 b paveiksle ciklinès vijų apkrovos parodytos tokiam atvejui, kai jungtis iveržiant yra necentriškai tempiama ir eksploatavimo metu dar patiria necentrišką ciklinị apkrovimą.

\subsection{Smeigès apkrovų ciklo parametrai}

Remiantis vijų porų apkrovimo schemomis, kurios pateiktos paveiksluose 4.34.6, galima matematinèmis formulèmis išreikšti pagrindinius vijų ciklinio apkrovimo parametrus. Toliau pateiktos formulès necentrinio tempimo ciklo vijų apkrovų ir smeigès įrąžų parametrams apskaičiuoti:

$$
\begin{gathered}
q_{\max }(z)=q_{t t}(z)+q_{t, 1}(z)+q_{b, 1}(z), \quad q_{\min }(z)=q_{\max }(z)-2 q_{r b, a}(z), \\
q_{b, 1}(z)=u(z) \sin (c z), \\
q_{a}(z)=q_{r t, a}(z)+q_{r b, a}(z), \quad q_{r b, a}(z)=\frac{1}{2} u_{r}(z) \sin (c z), \\
M_{\text {max }}(z)=M_{t t}(z)+R \int_{z_{0}}^{z} u(z) \sin ^{2}(c z) d z, M_{\min }(z)=M_{\text {max }}(z)-2 M_{r, a}(z), \\
M_{r, a}(z)=\frac{1}{2}\left[R \int_{z_{0}}^{z} u_{r}(z) \sin ^{2}(c z) d z\right], \\
Q_{\max }(z)=Q_{t t}(z)+\int_{z_{0}}^{z} q_{t}(z) \mathrm{d} z, Q_{\min }(z)=Q_{\max }(z)-2 Q_{a}(z), \\
Q_{r, a}(z)=\frac{1}{2}\left[\int_{z_{0}}^{z} q_{r t}(z) d z\right] .
\end{gathered}
$$

Vijų apkrovų ir smeigès įrąžų parametrai simetrinio dvipusio lenkimo ciklui yra tokie:

$$
\begin{gathered}
q_{\max }(z)=q_{t t}(z)+q_{b, 1}(z)=q_{t t}(z)+u_{h}(z) \sin (c z), \\
q_{\min }(z)=q_{\max }(z)-2 q_{r b, a}(z), \quad q_{r b, a}(z)=u_{r}(z) \sin (c z), \\
M_{\max }(z)=R \int_{z_{0}}^{z} u_{h}(z) \sin ^{2}(c z) d z, M_{\text {min }}(z)=M_{\max }(z)-2 M_{r, a}(z),
\end{gathered}
$$




$$
M_{r, a}(z)=R \int_{z_{0}}^{z} u_{r}(z) \sin ^{2}(c z) d z .
$$

Vijų apkrovų ir smeigès įrąžų parametrai vienpusio lenkimo ciklui yra tokie:

$$
\begin{gathered}
q_{\max }(z)=q_{t t}(z)+q_{b, 1}(z)=q_{t t}(z)+u_{h}(z) \sin (c z), \\
q_{\min }(z)=q_{\max }(z)-2 q_{r b, a}(z), \quad q_{r b, a}(z)=\frac{1}{2} u_{r}(z) \sin (c z), \\
M_{\max }(z)=R \int_{z_{0}}^{z} u_{h}(z) \sin ^{2}(c z) d z, \quad M_{\min }(z)=M_{\max }(z)-2 M_{r, a}(z), \\
M_{r, a}(z)=\frac{1}{2} R \int_{z_{0}}^{z} u_{r}(z) \sin ^{2}(c z) d z .
\end{gathered}
$$

Šiame skyriuje pateiktose formulèse ašinès apkrovos ir ašiniai itempiai, kurie smeigeje atsiranda ivveržimo metu, pažymèti indeksu $t t$. Ciklo maksimalus ir minimalus parametrai bei amplitudè atitinkamai pažymèti su indeksais - max, min, a. Bet kuriu parametrų pokytis po pirmojo apkrovimo pirmajame pusciklyje turi indeksa - 1. Apkrovimo ciklo parametrai, kurie kinta dèl ašinès jègos pokyčio, pažymèti indeksu $t$.

\subsection{Smeigès vietinių itempių ciklo parametrai}

Atominès energetikos pramoneje įrengimų skaičiavimo normos (RF normos 1989) ittempių koncentracijos zonose sriegio įdubos ciklinis stiprumas įvertinamas pagal vietinius sąlyginius tampriuosius ittempius $\sigma^{*}$. Šiose normose vietiniai sąlyginiai tamprieji itempiai smeigei apskaičiuojami nepaisant apkrovos pasiskirstymo vijose ir taikant vieną itempių koncentracijos koeficienta. Šiame darbe smeigés vietiniai sąlyginiai tamprieji itempiai, kuriais remiamasi skaičiuojant normini srieginiu jungčių ciklinị ilgaamžiškumą, nustatomi pagal ịveržimo ir lenkimo apkrovų pasiskirstymo sriegyje duomenis.

Cikliškai lenkiamos srieginès jungties mažaciklis ilgaamžiškumas nustatomas pasitelkiant pavojingojo smeigès skerspjūvio vietinių itempių ciklo parametrus. Pavojinguoju skerspjūviu laikomas didžiausią itempių kitimo aplitudę patiriantis smeigès skerspjūvis, kurio koordinate žymima $z_{C}$. Smeigès sriegio vietiniu itempių ciklo parametrai nustatomi pagal vijų apkrovos ir vidinio lenkimo momento pasiskirstymą, kuris atsiranda vijų sraigtinei linijai esant fazejje $I$. 
Lyginant su kitų fazių atvejais, pirmos (I) vijų sraigtinès linijos fazės atveju smeigè pavojingajame skerspjūvyje turi didžiausią maksimalių vietinių įtempių reikšmę.

Vietiniu itempių parametrai necentrinio tempimo cikle yra tokie:

$$
\begin{gathered}
\sigma_{\max }^{*}(z)=\sigma_{t t}^{*}(z)+\sigma_{t, 1}^{*}(z)+\sigma_{b, 1}^{*}(z), \quad \sigma_{\min }^{*}(z)=\sigma_{\max }^{*}(z)-2 \sigma_{a}^{*}(z), \\
\sigma_{t t}^{*}(z)=K_{t, m} \frac{q_{t t}(z) \cdot P}{f}+K_{t, 0} \frac{Q_{t t}(z)}{A_{s}}, \\
\sigma_{t, 1}^{*}(z)=K_{t, m} \frac{q_{t, 1}(z) \cdot P}{f}+K_{t, 0} \frac{Q_{t, 1}(z)}{A_{s}}, \\
\sigma_{b, 1}^{*}(z)=K_{b, m} \frac{q_{b, 1}(z) \cdot P}{f}+K_{b, 0} \frac{M_{1}(z)}{I_{s}} R_{v} \sin (c z), \\
\sigma_{a}^{*}(z)=\sigma_{t, a}^{*}(z)+\sigma_{b, a}^{*}(z), \sigma_{t, a}^{*}(z)=K_{t, m} \frac{q_{t r, a}(z) \cdot P}{f}+K_{t, 0} \frac{Q_{r, a}(z)}{A_{s}}, \\
\sigma_{b a}^{*}(z)=K_{b, m} \frac{q_{r b, a}(z) \cdot P}{f}+K_{b, 0} \frac{M_{r, a}(z)}{I_{s}} R_{v} \sin (c z) .
\end{gathered}
$$

Vietinių itempių parametrai dvipusio ir vienpusio lenkimo cikle yra tokie:

$$
\begin{gathered}
\sigma_{\max }^{*}(z)=\sigma_{t t}^{*}(z)+\sigma_{b, 1}^{*}(z), \quad \sigma_{\min }^{*}(z)=\sigma_{\max }^{*}(z)-2 \sigma_{a}^{*}(z), \\
\sigma_{t t}^{*}(z)=K_{t, m} \frac{q_{t t}(z) \cdot P}{f}+K_{t, 0} \frac{Q_{t t}(z)}{A_{s}}, \\
\sigma_{b, 1}^{*}(z)=K_{b, m} \frac{q_{b, 1}(z) \cdot P}{f}+K_{b, 0} \frac{M_{1}(z)}{I_{s}} R_{v} \sin (c z), \\
\sigma_{a}^{*}(z)=K_{b, m} \frac{q_{r b, a}(z) \cdot P}{f}+K_{b, 0} \frac{M_{r, a}(z)}{I_{s}} R_{v} \sin (c z) .
\end{gathered}
$$




\subsection{Modifikuoto norminio mažaciklio ilgaamžiškumo skaičiavimo taikymas cikliškai lenkiamoms srieginėms jungtims}

Šiame skyriuje pateiktas norminio ir modifikuoto norminio lenkiamu jungčių mažaciklio ilgaamžiškumo skaičiavimo rezultatu palyginimas su eksperimentiniais duomenimis.

Normose cikliniam ilgaamžiškumui skaičiuoti yra pateiktos dvi Kofino Mensono - Langerio tipo formulès. Mažesnioji apkrovimo ciklų skaičiaus iki plyšio atsiradimo smeigejje $N_{0}$ reikšmè, nustatyta iš dviejų apskaičiuotu pagal šias formules, laikoma skaičiavimo rezultatu. Šių formulių išraiškos yra tokios:

$$
\begin{aligned}
& \sigma_{a}^{*}=\frac{E_{1 s} e_{c}}{\left(4 N_{0}\right)^{m}}+\frac{R_{-1}}{1+\left(R_{-1} / R_{m}\right)\left[\left(1+r_{c}\right) /\left(1-r_{c}\right)\right]}, \\
& \sigma_{a}^{*}=\frac{E_{1 s} e_{c}}{\left(4 N_{0}\right)^{m}}+\frac{R_{c}}{\left(4 N_{0}\right)^{m_{e}}+\left[\left(1+r_{c}\right) /\left(1-r_{c}\right)\right]},
\end{aligned}
$$

čia $R_{1}$ yra medžiagos patvarumo riba, $e_{c}$ yra medžiagos plastiškumo rodiklis, nustatomas ivertinant standartinio tempiamo cilindrinio bandinio skerspjūvio ploto pokyti $Z, R_{c}$ yra medžiagos stiprumo rodiklis, nustatomas ivertinant stiprumo ribos $R_{m}$ reikšmę, $m$ ir $m_{e}$ laipsnio rodikliai $\left(m_{e}=0,132 \lg \left[\left(R_{m} / R_{-1}\right)\left(1+1,4 \cdot 10^{-2} Z\right)\right]\right), r_{c}$ yra sriegio vietiniu itempių asimetrijos koeficientas, $\sigma_{a}^{*}$ yra sąlyginių tampriujų vietinių itempių amplitudè, kuri normose nustatoma pagal formules: $\sigma_{a}^{*}=K_{\sigma} \sigma_{a, n o m}$ ir $K_{\sigma}=1+1,57 \sqrt{P / R_{r}}$, kuriose $K_{\sigma}$ yra smeigès sriegio itempių koncentracijos koeficientas, $\sigma_{a, n o m}^{*}$ yra smeigès nominalaus itempio amplitudè, $R_{r}$ yra sriegio įdubos apvalinimo spindulys.

Pasitelkus cikliškai lenkiamos smeigès sriegyje pasiskirsčiusių ittempių $\sigma_{b a}^{*}(z)$ reikšmes galima apskaičiuoti ciklų skaičių iki plyšio atsiradimo $N_{0}(z)$ bet kuriai sriegio iddubai, kurios padètị apibrèžia koordinate $z$, taip pat ir pavojingajai sriegio įdubai su koordinate $z_{C}$. Anksčiau tokia galimybe cikliškai tempiamos jungties atvejui patikrinta taikant modifikuotą norminę formulę (Krenevičius, Leonavičius 2008), kurios išraiška yra tokia:

$$
\sigma_{a}^{*}\left(z_{C}\right)=\frac{E_{1 s} e_{c}}{\left[4 N_{0}\left(z_{C}\right)\right]^{m}}+\frac{R_{c}}{\left[4 N_{0}\left(z_{C}\right)\right]^{\bar{m}_{e}}+\frac{1+r_{c}}{1-r_{c}}},
$$

čia $\bar{m}_{e}=0,78\left(Z 10^{-2}\right)-0,26\left(R_{m} 10^{-3}\right)$ yra koreguotas norminès formulès (4.29) laipsnio rodiklis, kurio taikymo galimybe isitikinta, sulyginus 294 cikliškai tem- 
piamų srieginių jungčių M16, M20 ir M42 ilgaamžiškumo eksperimentinius duomenis su atitinkamais ciklinio ilgaamžiškumo skaičiavimo rezultatais.

Cikliškai lenkiamos jungties atvejui norminių formulių (4.28) bei (4.29) ir modifikuotos norminès formulès (4.18) taikymas patikrintas sulyginus cikliškai lenkiamų jungčių M16×2 ilgaamžiškumą iki plyšio atsiradimo $N_{0, \exp }\left(z_{C}\right)$ su atitinkamais ciklinio ilgaamžiškumo skaičiavimo rezultatais, su $N_{0, \text { skaic }}\left(z_{C}\right)$ reikšmèmis.

Palyginimui remtasi cikliškai lenkiamų jungčių M16×2 (pagamintų iš plieno 25X1MF) ilgaamžiškumo tyrimo rezultatais, anksčiau atliktais VGTU stiprumo mechanikos bandymų laboratorijoje. Eksperimentinis $3-6 \mathrm{~mm}$ ilgio makroplyšio atsiradimas (sriegio įdubos perimetre) buvo nustatomas magnetiniu liuminescenciniu metodu. Plyšio ilgio matavimai atliekami bandymo pertraukose periodiškai išardžius srieginę jungti. Atlikus matavimą ji surenkama i pradinį būvị tolesniam bandymui.

Eksperimentais tirtu ir skaičiavimais tikrintų srieginių jungčių (veržlè smeigè - veržlè) M16 ciklinio apkrovimo parametrai pateikti 4.1 lentelèje.

4.1 lentelè. Srieginiu jungčių Ciklinio apkrovimo parametrai

Table 4.1. Parameters of cyclical loading of the threaded conections

\begin{tabular}{|c|c|c|c|l|}
\hline $\begin{array}{l}\text { Bandinio } \\
\text { Nr. }\end{array}$ & $\frac{\sigma_{t, \text { nom }}}{R_{p 0,02}}$ & $\frac{\sigma_{b, \text { nom }}}{R_{p 0,02}}$ & $r=\frac{\sigma_{\text {min,nom }}}{\sigma_{\text {max, nom }}}$ & Lekimo pobūdis \\
\hline 1 & 0,74 & 0,4 & 0,30 & dvipusis \\
\hline 2 & 0,72 & 0,38 & 0,30 & dvipusis \\
\hline 3 & 0,69 & 0,64 & 0,04 & dvipusis \\
\hline 4 & 0,68 & 0,62 & 0,05 & dvipusis \\
\hline 5 & 0,61 & 0,57 & 0,52 & vienpusis \\
\hline 6 & 0,64 & 0,59 & 0,52 & vienpusis \\
\hline 7 & 0,43 & 0,294 & 0,19 & dvipusis \\
\hline 8 & 0,437 & 0,308 & 0,19 & dvipusis \\
\hline 9 & 0,59 & 0,175 & 0,54 & dvipusis \\
\hline 10 & 0,543 & 0,162 & 0,54 & dvipusis \\
\hline 11 & 0,547 & 0,164 & 0,54 & dvipusis \\
\hline 12 & 0,65 & 0,31 & 0,36 & dvipusis \\
\hline 13 & 0,57 & 0,31 & 0,31 & dvipusis \\
\hline
\end{tabular}

4.8 ir 4.9 paveiksluose parodyta eksperimentinių duomenų ir skaičiavimų, atliktų pagal normų formules (4.28), (4.29) ir (4.30), rezultatų palyginimas. 4.8 ir 4.9 paveiksluose linijos $1,2,3,4$ paeiliui išreiškia tokius ciklų skaičių santykius: $N_{0, \exp } / N_{0, \text { calc }}=1,2,5,10$. Eksperimentiniai taškai išsidèstę linijoje 1 , rodo eksperimentinių ir apskaičiuotų ilgaamžiškumų sutapimą. Pagal visas tris formu- 
les beveik visi apskaičiuotieji ilgaamžiškumai yra atsargos pusèje nuo linijos 1 . Apskaičiuotos $N_{0, \text { calc }}$ reikšmès pagal normų formulę (4.28) ir dauguma reikšmių $N_{0, \text { calc }}$, apskaičiuotu pagal formulę (4.29), yra 5-15 ir 2-10 kartu atitinkamai didesnès už eksperimentines $N_{0, \text { exp }}$ reikšmes (4.8 pav.). Penki apskaičiuotieji pagal normų formulę (4.29) taškai, kurie atspindi ilgaamžiškumą iki plyšio atsiradimo viršijanti $10^{4}$ ciklų, yra ant linijos 1 arba labai arti jos (4.8 pav.).

Pagal modifikuotą norminę formulę (4.30) apskaičiuotu $N_{0, \text { calc }}$ reikšmių išsibarstymas yra gerokai mažesnis. Jos didesnès už eksperimentines $N_{0, \text { exp }}$ reikšmes, bet viršija jas daugiausiai apie du kartus (4.9 pav.).

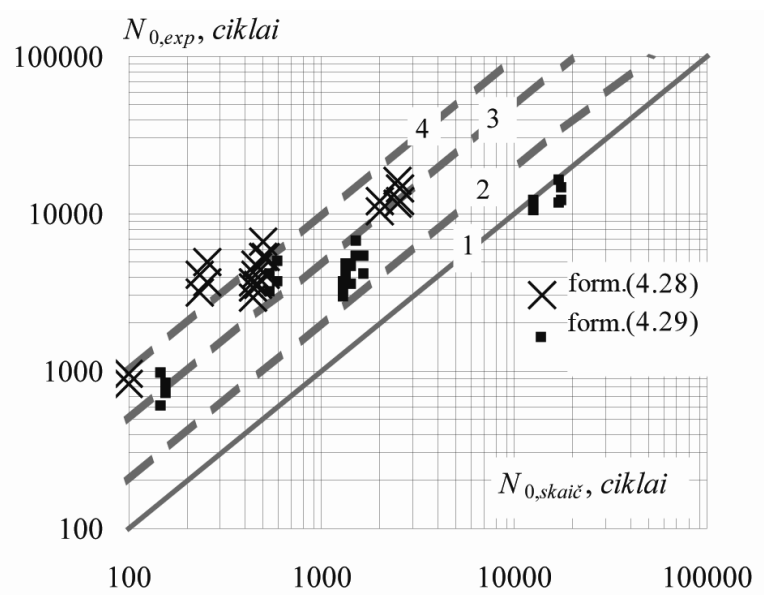

4.8 pav. Jungties M16 $\times 2$ ciklinio ilgaamžiškumo rezultatų palyginimas Fig. 4.8. Comparison of cyclic lifetimes for stud-nut connections $M 16 \times 2$

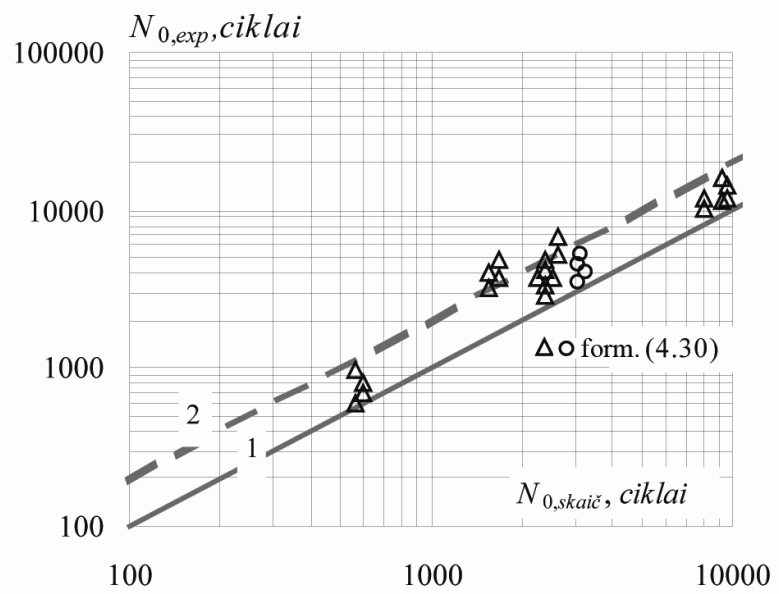

4.9 pav. Plyšio atsiradimas jungties M16 $\times 2$ smeigès sriegyje

Fig. 4.9. Crack initiation in thread of stud $M 16 \times 2$ 
Žinant, kad iprastas plieninių glotnių bandinių ir bandinių su koncentratoriais eksperimentinių ciklinio ilgaamžiškumo reikšmių išsibarstymas yra panašaus lygio, galima laikyti, kad skaičiavimas pagal modifikuotą norminę formulę (4.30) yra priimtinas.

\subsection{Ketvirtojo skyriaus išvados}

1. Kai sriegine jungtis po įveržimo pirmajame pusciklyje necentriškai tempiama taip, kad visame viju perimetre jų apkrova dideja, tai abiejose jungties pusèse nuo neutraliosios plokštumos pusvijų porų paslankumo reikšmė yra vienoda $-\gamma_{f}$.

2. Kai iveržta jungtis pirmą kartą patiria tik lenkimo apkrovą, tuomet vienoje pusejje nuo neutraliosios plokštumos sriegio pusviju paslankumo reikšmè yra $\gamma_{f}$, kitoje $-\gamma_{r}$.

3. Kai vyksta ivveržtos jungties ciklinis lenkimas arba necentrinis ciklinis tempimas, tuomet abiejose pusèse nuo neutraliosios plokštumos pusvijų porų paslankumo reikšmė yra vienoda $-\gamma_{r}$. Taikant šią reikšmę, nustatomos pasikartojančio apkrovimo ciklo amplitudès $-q_{a}(z), M_{a}(z)$ ir $\sigma_{a}(z)$.

4. Cikliškai lenkiamų srieginių jungčių pakartotinio ciklo maksimalios apkrovų ir įtempių reikšmès $-q_{\max }(z), M_{\max }(z)$ ir $\sigma_{\max }(z)$ - yra lygios atitinkamoms reikšmėms, nustatytoms pirmojo apkrovimo pusciklio atvejui, ivvertinus pusvijų apkrovimo pobūdi ir taikant joms ši pobūdi atitinkančias vijų paslankumo reikšmes.

5. Sudarytas trijų ruožų srieginès jungties modelis yra racionalesnis už daugiaruoži modeli, taikant juos ciklinio necentrinio tempimo atvejams, kai pusvijų, esančiu priešingose jungties pusèse, apkrovimo pobūdis yra visuomet vienodas jos apkraunamos arba nukraunamos.

6. Daugiaruožis srieginès jungties modelis, sudarytas po i̇veržimo lenkiamų jungčių atvejui, ịvertina skirtinga pusvijų, esančių priešingose nuo NL jungties pusėse, apkrovimo pobūdi pirmajame pusciklyje, kai vienoje puseje jos apkraunamos, o kitoje nukraunamos, ir vienodą pusvijų apkrovimo pobūdi pasikartojančiuose puscikliuose, kai jos apkraunamos arba nukraunamos.

7. Cikliškai lenkiamų srieginiu jungčių apkrovos pasiskirstymo sriegio vijose duomenų taikymas mažaciklio ilgaamžiškumo skaičiavimuose gali būti realizuotas naudojant modifikuotą norminę formulę (4.30).

8. Mažaciklis cikliškai lenkiamų srieginių jungčių ilgaamžiškumas (pagal plyšio atsiradima) iki $2 \cdot 10^{4}$ ciklų, nustatytas pagal modifikuotą norminę formulę (4.30), yra 2-5 kartus didesnis už ilgaamžiškumo reikšmes, apskaičiuotas pagal normas (RF normos 1989). Jos yra artimos eksperimentinèms ilgaamžiškumo reikšmèms ir jų neviršija. 


\section{Srieginių jungčių ciklinio ilgaamžiškumo padidinimas}

Šiame skyriuje pateikti du būdai skirti srieginių jungčių cikliniam ilgaamžiškumui padidinti.

Pirmas būdas skirtas cikliškai lenkiamos jungties ilgaamžiškumui padidinti taikant jungties pozicionavimo metodą. Jungties pozicionavimo būdas realizuojamas eksploatavimo metu periodiškai keičiant jungties padètị lenkimo plokštumos atžvilgiu. Periodiškai sukeičiant vietomis jëgų ir neutraliają plokštumas, keičiama ir didžiausių ciklinių pažeidimų kaupimo vieta smeigeje. Tokiu būdu smeigès ciklinis ilgaamžiškumas gali būti padidintas iki 2 kartų.

Antras būdas skirtas ašine cikline apkrova veikiamos jungties ilgaamžiškumo padidinimui, kuris yra paremtas smeigès sriegio maksimalių vietinių itempių sumažinimu. Šis būdas realizuojamas, panaudojant išankstinį srieginès jungties perkrovima, dèl kurio vijos igauna liekamuosius įlinkius. Po perkrovimo nukrovus jungtị dèl liekamujų ilinkių tarp smeigès ir veržlès vijų atsiranda tarpelių. Antrą kartą apkrovus jungtị mažesne jẻga, dèl esamų tarpelių jègos sriegyje persiskirsto ir pirmujų pavojingujų vijų apkrova bei vietiniai itempiai sumažeja.

Skyriaus medžiaga publikuota atoriaus straipsniuose (Krenevičius, Juchnevičius et al. 2008, Juchnevičius et al. 2009, Krenevičius, Juchnevičius et al. 2011d). 


\subsection{Lenkiamos srieginės jungties pozicionavimo metodas}

\subsubsection{Ciklinio ilgaamžiškumo padidinimo modelis}

Srieginès jungties ilgaamžiškumo padidinimo modelis remiasi sukauptų nuovarginių pažeidimų išlyginimu labiausiai apkrautų vijų įdubose - visame šių vijų perimetre. Metodas realizuojamas eksploatavimo metu periodiškai keičiant jungties padèti lenkimo plokštumos atžvilgiu. Šiam tikslui nuo ivveržimo jègos $F_{t}$ atpalaiduota smeigè prieš pradedant kitą apkrovimo periodą pasukama $90^{\circ}$ laipsnių kampu apie savo aši ir vèl ịveržiama. $5.1 \mathrm{a}$ ir b paveiksluose yra parodytos dvi jungties padètys $I$ ir $I I$, kuriose smeigè pakaitomis patiria ciklinę lenkimo apkrovą $M_{f}$.
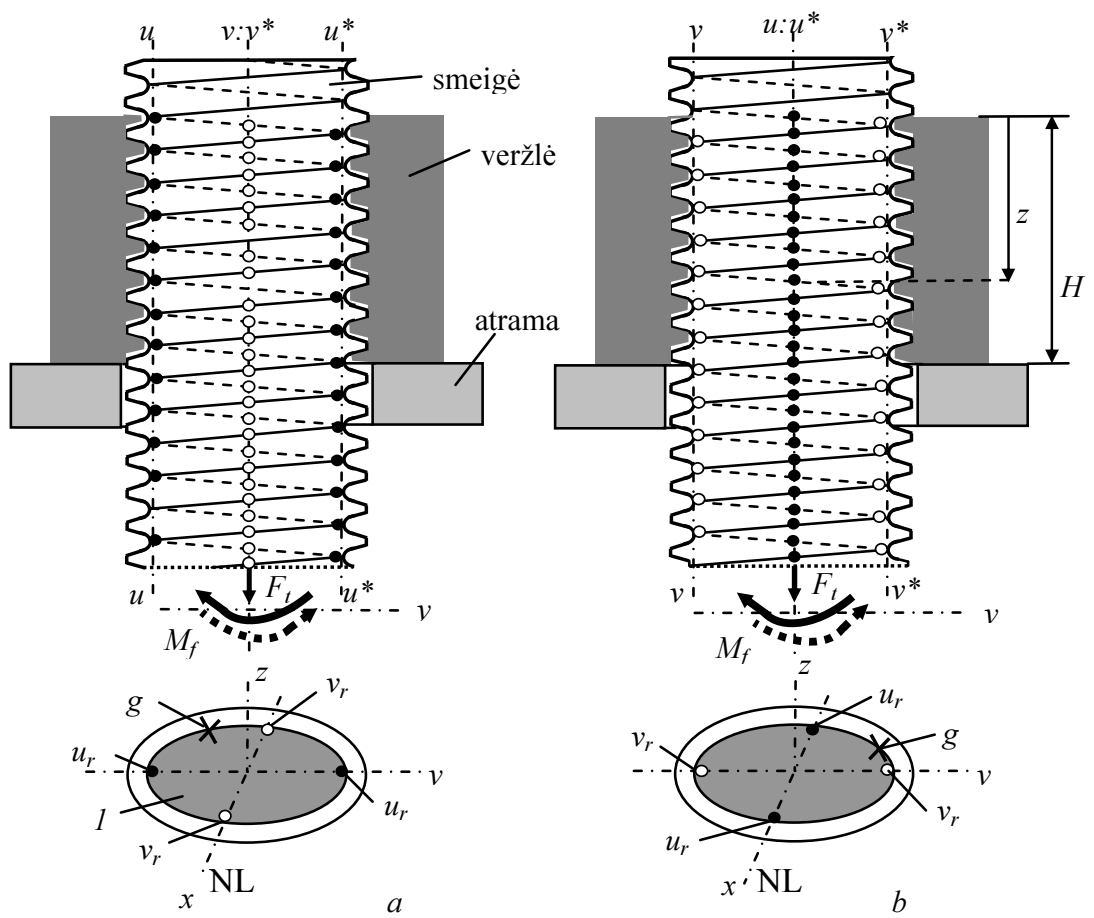

5.1 pav. Jungties ir lenkimo plokštumos tarpusavio padètys: padètis $I$ (a), padètis $I I$ (b) Fig. 5.1. Positions of connection respect to bending plane: position $I$ (a), position $I I$ (b)

Padètyje $I$ ekstremalių nominalių ir maksimalių vietinių i̇tempių dèl lenkimo atsiranda smeigès sriegio įdubose, kurias liečia linijos $u$ ir $u^{*}$ (juodi taškai 
5.1 pav.). Kiekviena įduba, kurią žymi baltas taškas, yra ant atitinkamos neutraliosios skerspjūvio linijos, kur ịtempių dèl lenkimo neatsiranda. Visus šiuos taškus jungia vertikalios linijos $v$ ir $v^{*}$. Kai jungtis eksploatuojama padètyje $I I$, viju idubos, kurios yra linijose $u, u^{*}$, yra susikeitusios vietomis su viju įdubomis, kurios yra linijose $v, v^{*}$. Padètyje $I I$ ekstremaliu itempių dèl lenkimo atsiranda smeigès sriegio įdubose, kurias liečia linijos $v$ ir $v^{*}$. Taigi, padètyje $I$ cikliniai pažeidimai intensyviausiai yra kaupiami taškuose $u$ ir $u^{*}$, jų neatsiranda taškuose $v$ ir $v^{*}$. Padetyje $I I$ (priešingai negu padètyje $I$ ) cikliniai pažeidimai intensyviausiai yra kaupiami smeigès taškuose $v$ ir $v^{*}$ ir jų neatsiranda taškuose $u$ ir $u^{*}$. Bet kuriame tarpiniame taške $g$ (5.1 pav.) cikliniai pažeidimai kaupiami eksploatuojant jungti abiejose srieginès jungties padètyse.

Tarkime, kad plyšio atsiradimas smeigès sriegyje priklauso tik nuo sukauptų ciklinių pažeidimų pavojinguose taškuose $u_{r}$ ir $v_{r}$, kurie yra išeinančių iš sukibimo vijų srityje ties veržlès atrama. Jeigu jungtis būtų eksploatuojama tik padètyje $I$, tai plyšys anksčiausiai atsirastu įduboje $u_{r}$, tarkime, po $N_{I, 0}$ apkrovimo ciklų. Kitu atveju, jeigu jungtis būtų eksploatuojama tik padètyje $I I$, tai plyšys anksčiausiai atsirastų iduboje $v_{r}$, tarkime, po $N_{I I, 0}$ apkrovimo ciklų. Kai srieginè jungtis eksploatuojama periodiškai keičiant jos padèti lenkimo plokštumos atžvilgiu, t. y. pakaitomis padetyse $I$ ir $I I$, tai pažeidimai kaupiami taškuose $u_{r}$ ir $v_{r}$ vyksta tik jiems esant vienoje padètyje: taške $u_{r}$, esant jungties paděčiai $I$ ir taške $v_{r}$, esant jungties padèčiai II. Tuomet (nesvarbu, koks būtų apkrovimo periodų skaičius) visa ciklinio apkrovimo trukmè, išreikšta ciklais yra lygi $N_{\Sigma}=N_{I, 0}+N_{I I, 0}$.

Trečiame skyriuje parodyta, kad lenkimo atveju pavojingasis taškas yra išeinančios iš sukibimo smeigès vijos, esančios arti atramos, įduboje (5.1 pav.). Tiksli jo vieta priklauso nuo vijų sraigtinès linijos padèties lenkimo plokštumos atžvilgiu. Tačiau, nesvarbu, kur būtų šio taško padètis - truputi arčiau ar toliau nuo veržlès atramos - vietinių itempių reikšmè praktiškai lieka vienoda t. y. $N_{I, 0} \approx N_{I I, 0}=N_{0}$. Tuomet visa ciklinio apkrovimo trukmé iki plyšio atsiradimo yra lygi $N_{\Sigma}=N_{I, 0}+N_{I I, 0} \approx 2 N_{0}$. Toliau toki pat rezultatą gausime, pritaikę Mainerio tiesinio pažeidimų sumavimo principa.

Tiesinio pažeidimų sumavimo lygtys, užrašytos pavojingiesiems taškams $u_{r}$, ir $v_{r}$, kurie kas antro apkrovimo periodo metu yra ant neutraliosios linijos, o kitų periodų metu yra toliausiai nutolę nuo jos, turi tokius pavidalus:

$$
\begin{aligned}
& \frac{N_{1}}{N_{I, 0}\left(z_{u r}\right)}+\frac{N_{2}}{\infty}+\frac{N_{3}}{N_{I, 0}\left(z_{u r}\right)}+\frac{N_{4}}{\infty}+\ldots \ldots+\cdot \frac{N_{j-1}}{N_{I, 0}\left(z_{u r}\right)}+\frac{N_{j}}{\infty}=\omega_{u r}, \\
& \frac{N_{1}}{\infty}+\frac{N_{2}}{N_{I I, 0}\left(z_{v r}\right)}+\frac{N_{3}}{\infty}+\frac{N_{4}}{N_{I I, 0}\left(z_{v r}\right)}+\ldots . . \frac{N_{j-1}}{\infty}+\frac{N_{j}}{N_{I I, 0}\left(z_{v r}\right)}=\omega_{v r},
\end{aligned}
$$


čia $z_{u r}$ ir $z_{v r}$ yra pavojinguju taškų $u_{r}$, ir $v_{r}$ koordinatès; $N_{I, 0}\left(z_{u r}\right)$ ir $N_{I I, 0}\left(z_{v r}\right)$ yra ciklų skaičius iki plyšio atsiradimo $I$ ir $I I$ jungties apkrovimo padètyse, kai jungties padètis ( $I$ arba $I I$ atitinkamai) eksploatavimo eigoje nekeičiama, $N_{I I, 0}\left(z_{u r}\right)=\infty$ ir $N_{I, 0}\left(z_{v r}\right)=\infty$, kai atitinkami taškai $u_{r}$ ir $v_{r}$ yra ant neutraliosios linijos; $N_{l}$, $N_{3} \ldots . . N_{j-1}$ yra ciklinio apkrovimo periodu trukmé (ciklais), kurių metu srieginè jungtis yra padetyje $I ; N_{2}, N_{4} \ldots . N_{j}$ yra ciklinio apkrovimo periodų trukmé (ciklais), kurių metu srieginè jungtis yra padètyje $I I, j$ yra paskutinio periodo eilès numeris, $\omega_{u r}$ ir $\omega_{v r}$ sukauptu pažeidimų suma pavojinguosiuose taškuose $u_{r}$, ir $v_{r}$.

Pagal Mainerio principą medžiagoje plyšys atsiranda, kai ciklinių pažeidimų suma $\omega=1$. Tuomet optimaliam atvejui, kai $\omega_{u r}=\omega_{v r}, \omega_{u r}=1$ ir $\omega_{v r}=1$, panaudojant lygtis (5.1) ir (5.2), srieginès jungties visą ciklinį ilgaamžiškumą galima nustatyti tokia tvarka:

$$
\begin{gathered}
N_{I, \Sigma}=N_{1}+N_{3}+N_{5}+\ldots . .+N_{j-1}=N_{I, 0}\left(z_{u r}\right)=N_{0}, \\
N_{I I, \Sigma}=N_{2}+N_{4}+N_{6}+\ldots . .+N_{j}=N_{I I, 0}\left(z_{v r}\right)=N_{0}, \\
N_{I, \Sigma}=N_{I I, \Sigma}, \quad N_{\Sigma, u, v}=N_{I, \Sigma}+N_{I I, \Sigma}=2 N_{0} .
\end{gathered}
$$

Tokiu būdu apskaičiuotas optimalus suminis ciklinis ilgaamžiškumas $N_{\Sigma, u, v}=2 N_{0}$ yra priimtinas, jeigu leidžiama, kad srieginè jungtis paskutiniojo apkrovimo periodo $N_{j}$ metu būtų eksploatuojama su vos atsiradusiu plyšiu, kuris šio apkrovimo periodo metu yra ant neutraliosios skerspjūvio linijos ir ciklinès apkrovos nepatiria (plyšys nesivysto ir yra nepavojingas). Šiuo atveju smeige su plyšiu patiria tik statinę ašinę ivveržimo jẻgą. Tačiau dèl plyšio atsiranda smeigès trapaus suirimo grèsmè, todèl, naudojant irimo mechanikos taisykles, šiuo atveju turi būti patikrinta ir plyšio stabilumo sąlyga. Kitu atveju konstrukcijoje, kuriai nustatyti saugumo reikalavimai yra dideli, tas gali būti nepriimtina (nes, kaip buvo paminèta, smeigès skerspjūvis su plyšiu patiria statinę ašinę apkrovą dèl iveržimo). Todèl antruoju atveju srieginès jungties visas ciklinis ilgaamžiškumas turi būti apskaičiuotas tokiu būdu:

$$
N_{\Sigma, u, v}^{*}=2 N_{0}-N_{j} .
$$

Šiuo atveju $N_{j}$ toliau bus vadinamas fiktyviuoju paskutiniuoju apkrovimo periodu. Tikroji reali paskutiniojo periodo trukmé šiuo atveju yra $N_{j-l}$.

Akivaizdu, kad rezultatas išreikštas lygtimi (5.5) (arba lygtimi (5.6)), yra tinkamas tik tuo atveju, jeigu visuose tarpiniuose taškuose $g$ (pagal 5.1 pav.) ciklinių pažeidimų suma $\omega_{g} \leq 1$. Tiesinio pažeidimų sumavimo lygtis, užrašyta bet kuriam smeigès sriegio įdubos taškui (ir tarpiniam) su koordinate $z$, turi tokią išraišką: 


$$
\frac{N_{1}}{N_{I, 0}(z)}+\frac{N_{2}}{N_{I I, 0}(z)}+\frac{N_{3}}{N_{I, 0}(z)}+\frac{N_{4}}{N_{I I, 0}(z)}+\ldots . .+\frac{N_{j}}{N_{I I, 0}(z)}=\omega_{g},
$$

čia $N_{I, 0}(z)$ ir $N_{I I, 0}(z)$ yra ciklų skaičius iki plyšio atsiradimo nagrinėjamame taške, esant jungčiai apkrovimo padètyse $I$ ir atitinkamai $I I$, kai jungties padètis ( $I$ arba II) eksploatavimo eigoje nekeičiama.

Toliau, panaudojant tarpinių taškų $g$ optimalumo sąlygas, reikia vèl apskaičiuoti suminio ciklinio ilgaamžiškumo $N_{\Sigma}(z)$ reikšmę ir palyginti ją su reikšmę $N_{\Sigma, u, v}=2 N_{0}$, kuri jau nustatyta pagal taškų $u_{r}$, ir $v_{r}$ optimalumo sąlygas. Vieną optimalumo sąlygą imame iš lygčių (5.5) t. y. $N_{I, \Sigma}=N_{I I, \Sigma}$. Kita sąlyga yra $\omega_{g}=1$. Tuomet žinant, kad tarpiniuose taškuose $g$ galioja nelygybé $N_{I, 0}(z) \neq N_{I, 0}(z) \neq N_{0}$, suminio ilgaamžiškumo $N_{\Sigma}(z)$ reikšmè gali būti nustatyta iš lygties (5.7) tokiu būdu:

$$
\begin{gathered}
\frac{N_{I, \Sigma}}{N_{I, 0}(z)}+\frac{N_{I I, \Sigma}}{N_{I I, 0}(z)}=1, \quad N_{I, \Sigma}=N_{I I, \Sigma}, \\
N_{\Sigma}(z)=N_{I, \Sigma}+N_{I I, \Sigma}=2 \frac{N_{I, 0}(z) \cdot N_{I I, 0}(z)}{N_{I, 0}(z)+N_{I I, 0}(z)} .
\end{gathered}
$$

Mažiausioji reikšmè iš visų nustatytujų pagal formules (5.5) ir (5.8) t. y. iš $N_{\Sigma, u, v}$ ir $N_{\Sigma}(\mathrm{z})$, yra ieškomoji smeigès suminio ciklinio ilgaamžiškumo reikšmè, kai naudojami periodiški jungties padèties pakeitimai lenkimo plokštumos atžvilgiu.

\subsubsection{Skaičiavimo rezultatai}

Suminis ciklinis ilgaamžiškumas buvo apskaičiuotas jungčiai M16×2 (5.1 pav.), pagamintai iš plieno $25 \mathrm{X} 1 \mathrm{MF}$, kurią veikia dvipusis simetriškas lenkimas. Veržlès aukštis $H=12,8 \mathrm{~mm}$. Smeigès santykiniai nominalūs ašiniai ịtempiai dèl iveržimo (vidutiniai itempiai cikle) yra $\sigma_{n o m, t} / R_{p 0,2}=0,57$. Smeigès nominalių itempiu ciklo amplitudè, atsrandanti dèl kintamo lenkimo momento, yra $\sigma_{\text {nom }, b} / R_{p 0,2}=0,31$. Apkrovu pasiskirstymas ir vietiniai itempiai smeigès sriegyje buvo apskaičiuoti pagal metodiką pateiktą trečiame skyriuje, o ciklinis ilgaamžiškumas apskaičiuotas pagal metodiką pateiktą ketvirtame skyriuje.

5.2 paveiksle matyti, kad jungties M16×2 suminis ciklinis ilgaamžiškumas $N_{\Sigma}$ pavojingojoje zonoje t. y. visame išeinančiu iš sukibimo vijų ruože yra beveik vienodas - mažiausioji reikšmė yra lygi $2 N_{0}$, o kitos nedaug iki $6 \%$ didesnès.

Taigi cikliškai lenkiamos srieginès jungties ilgaamžiškumą iki plyšio atsiradimo galima padidinti iki 2 kartu, periodiškai keičiant jungties padètị lenkimo 
plokštumos atžvilgiu - periodiškai vietomis sukeičiant jègų ir neutraliają plokštumas, jeigu plyšys atsiranda, kai $\omega_{u r}=1$ ir $\omega_{v r}=1$. Nustatant srieginès jungties kiekvieno apkrovimo periodo trukmę, sukaupti cikliniai pažeidimai neturi viršyti leistinosios reikšmès visame išeinančiu iš sukibimo vijų ruože.

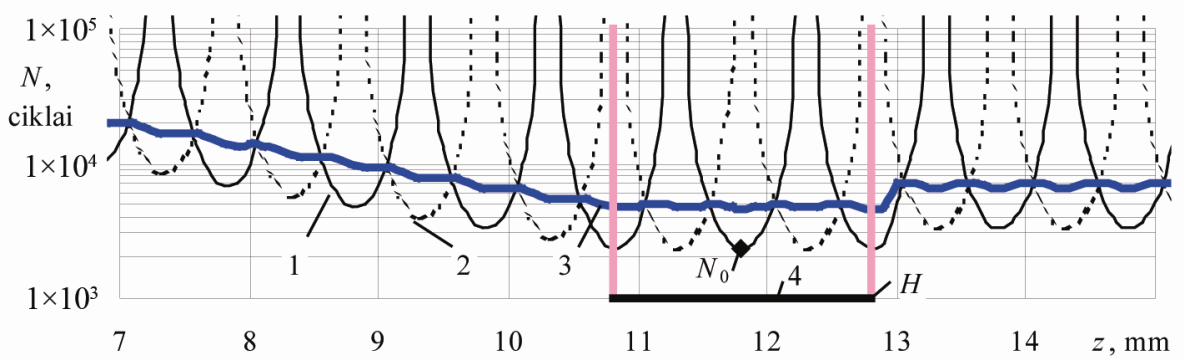

5.2 pav. Srieginès jungties M16 $\times 2$ ciklinis ilgaamžiškumas nekeičiant ir periodiškai keičiant jungties padètį: $N_{I, 0}(z)(1), N_{I I, 0}(z)(2), N_{\Sigma}(z)$ (3), išeinančių iš sukibimo vijų ruožo ilgis (4)

Fig. 5.2. Fatigue life of threaded connection $M 16 \times 2$ :

$N_{I, 0}(z)(1), N_{I I, 0}(z)(2), N_{\Sigma}(z)$ (3), length of the runout (4)

Ciklinio apkrovimo periodų visa trukmè abejose jungties padètyse turi būti vienoda $N_{I, \Sigma}=N_{I I, \Sigma}$, arba beveik vienoda $-N_{I, \Sigma}$ ir $N_{I I, \Sigma}-N_{j+I}$. Kuo mažesnè yra fiktyvaus paskutiniojo apkrovimo periodo trukmè $N_{j}$, tuo didesnis yra visas ciklinis ilgaamžiškumas.

\subsection{Srieginès jungties išankstinio perkrovimo metodas}

Šiame skyriuje pristatoma optimalesnio apkrovos pasiskirstymo sriegio vijose galimybe, kuri igyvendinama taikant išankstini jungties perkrovima. Atlikus pirmaji apkrovimą - perkrovimą ir po to nukrovima, dèl vijų plastinių deformacijų jungtyje tarp viju susidaro tarpeliai. Antrą kartą apkrovus jungtị mažesne jèga, dèl esamų tarpelių jègos pasiskirstymas vijose pagerèja. Pirmujų pavojingujju vijų apkrova sumažeja, palyginus su šių vijų apkrova, veikiant tai pačiai išorinei jègai, kai perkrovimas netaikomas. Taip atsitinka dèl palankaus tarpeliu dèsningumo. Didesni tarpeliai susidaro pirmuju pavojingujų vijų srityje, o mažesni jungties gilumoje. 


\subsubsection{Tampraus išankstinio perkrovimo modelis}

Šiame skyriuje nagrinejjamas paprasčiausias atvejis, kai vijų nukrovimas ir kartotinis apkrovimas pasireiškia ašine jèga tempiamoje srieginèje jungtyje. Gautos išvados yra svarbios ne vien tik cikliškai tempiamoms jungtims. Tam tikru laipsniu jomis galima pasiremti nagrinejant ir cikliškai lenkiamas sriegines jungtis.

Nagrinejjant kartotinai apkrautą tempiamą jungti, reikia išsiaiškinti kaip pasikeičia viju apkrova $q(z)$, pakartojus apkrovima. Viju apkrovos pasikeitimo galima tikètis dèl ženklaus vijų poros paslankumo reikšmiu skirtumo, kurias vijos turi apkraunant pirmą katrą ir kartojant apkrovimą.

Matematinio modelio supaprastinimui, nagrinèjama tempiama srieginè jungtis, kurioje vijos sukibusios visu profiliu visame jungties ilgyje $H \mathrm{t}$. y. jungties ỉvijų itakos nepaisoma (5.3 a pav.). Srieginę jungtị sudaro vienas ruožas.
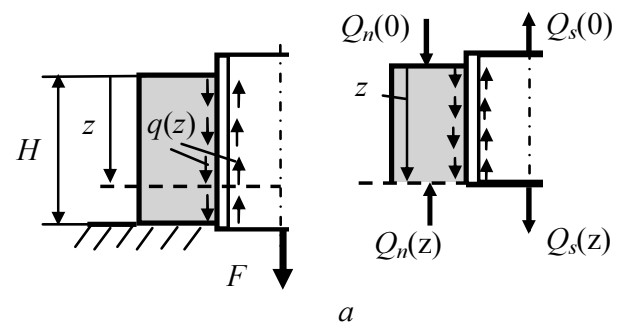
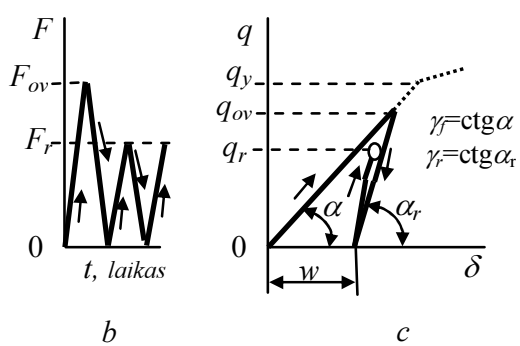

C

5.3 pav. Tempiamos srieginès jungties kartotinis apkrovimas

Fig. 5.3. Repeated axial loading of the threaded connection

Srieginè jungtis pirmą kartą apkraunama ašine jèga $F=F_{o v}$. Po nukrovimo, antrą kartą srieginè jungtis apkrauta iki $F=F_{r}(5.3 \mathrm{~b}$ pav.). Atitinkamos vijų apkrovos pirmojo ir antrojo apkrovimu pabaigoje yra $q_{o v}(z)$ ir $q_{r}(z)$. Šiame poskyryje nagrinejamas atvejis, kai jèga $F_{o v}$ nèra labai didelè ir todèl yra tenkinama salyga $q_{o v, \max }(z=H)<q_{y}$. Liekamasis vijuc poros illinkis $w$ atsiranda dél skirtingu vijų poros paslankumo reikšmių $\gamma_{f}$ ir $\gamma_{r}$, kurias vijos turi apkraunant ir nukraunant (5.3 c pav.). Čia $\gamma_{f}=\operatorname{ctg} \alpha$ ir $\gamma_{r}=\operatorname{ctg} \alpha_{r}$. Jungties pjūvyje z vijų poros liekamasis ilinkis yra toks:

$$
w(z)=\left(\gamma_{f}-\gamma_{r}\right) q_{o v}(z) .
$$

Apkrovos pasiskirstymą vieno ruožo sriegio vijose, apkrovus jungti jèga $F_{o v}$, aprašo tokia išraiška (Birger 1990):

$$
q_{o v}(z)=U_{t} \sinh \left(m_{t} z\right)+V_{t} \cosh \left(m_{t} z\right), \quad m_{t}^{2}=\beta / \gamma_{f} .
$$

Ivertinus tai, kad vieno ruožo jungčiai lygties (8.10) pastovieji koeficientai yra $U_{t}=0$ ir $V_{t}=\left(m_{t} F_{o v}\right) / \sinh \left(m_{t} H\right)$, ją naudinga perrašyti tokiu pavidalu: 


$$
q_{o v}(z)=\frac{m_{t} F_{o v}}{\sinh \left(m_{t} H\right)} \cosh \left(m_{t} z\right)
$$

Tam, kad būtų gauta išraiška, parodanti, kaip pasikeičia vijų apkrova $q_{r}(z)$ po antrojo apkrovimo, yra pasinaudota papildyta Birgerio srieginès jungties elementų išilginių poslinkių darnos lygtimi, kurioje įvertintas vijų liekamujų įlinkių didumas. Šios lygties bendriausias pavidalas yra toks:

$$
\Delta z_{s}+\left|\Delta z_{n}\right|=[\delta(z)-\delta(0)]+[w(z)-w(0)],
$$

čia $\Delta z_{s} ;\left|\Delta z_{n}\right|$ - smeigès šerdies ir veržlès sienelès skerspjūvių $z$ išilginiai poslinkiai.

Detaliau išreikšta išilginių poslinkių darnos lygtis yra tokia:

$$
\int_{0}^{z}\left[\frac{Q_{s}(0)+\int_{0}^{z} q_{r}(z) d z}{E_{s} A_{s}}\right] d z+\int_{0}^{z}\left[\frac{\left|Q_{n}(0)+\int_{0}^{z} q_{r}(z) d z\right|}{E_{n} A_{n}}\right] d z=\left[\gamma_{r} q_{r}(z)+w(z)\right]-\left[\gamma_{r} q_{r}(0)+w(0)\right] .
$$

Žinant, kad vieno ruožo jungties atveju $Q_{s}(0)=Q_{n}(0)=0$, ir panaudojus formules (5.9) bei (5.10), po lygties (5.13) dviejų diferecijavimu paeiliui gaunamos tokios išraiškos:

$$
\begin{gathered}
\beta \int_{0}^{z} q_{r}(z)=\gamma_{r} q_{r}^{\prime}(z)+w^{\prime}(z), \\
q_{r}^{\prime \prime}(z)-m_{r}^{2} q_{r}(z)=\left(m_{t}^{2}-m_{r}^{2}\right)\left[V_{t} \cosh \left(m_{t} z\right)\right], \quad m_{r}^{2}=\beta / \gamma_{r} .
\end{gathered}
$$

Diferencialinès lygties (5.15) sprendini $q_{r}(z)$ sudaro bendrasis ir atskiras sprendiniai. Bendrojo sprendinio $\bar{q}_{r}(z)$ forma yra tokia pat, kokią turi lygti (5.15) atitinkančios homogeninès lygties sprendinys. Atskiras sprendinys $\overline{\bar{q}}_{r}(z)$ turi būti ieškomas formoje, kuri atitinka dešinę diferencialinès lygties (5.15) pusę. Užrašyti šie sprendiniai atrodo taip:

$$
\begin{aligned}
& \bar{q}_{r}(z)=C_{r} \sinh \left(m_{r} z\right)+D_{r} \cosh \left(m_{r} z\right), \\
& \overline{\bar{q}}_{r}(z)=A_{t} \sinh \left(m_{t} z\right)+B_{t} \cosh \left(m_{t} z\right) .
\end{aligned}
$$

Atskiro sprendinio pastovieji koeficientai $A_{t}$ ir $B_{t}$ nustatomi, i lygti (5.15) istačius atskirojo sprendinio (5.17) pirmają ir antrają išvestines ir atskirai sulyginus narius, turinčius $A_{t}$ ir $B_{t}$. Šių koeficientu gautos išraiškos yra tokios:

$$
A_{t}=0, \quad B_{t}=\frac{F_{o v} m_{t}}{\sinh \left(m_{t} H\right)} .
$$


Tolesniam sprendimui naudosime viso lygties (5.15) sprendinio išraišką, kuri, ivvertinus (5.18), šioje sprendimo stadijoje atrodo taip:

$$
q_{r}(z)=C_{r} \sinh \left(m_{r} z\right)+D_{r} \cosh \left(m_{r} z\right)+\frac{F_{o v} m_{t}}{\sinh \left(m_{t} H\right)} \cosh \left(m_{t} z\right) .
$$

Lygties (5.19) koeficientams $\mathrm{C}_{r}$ ir $D_{r}$ nustatyti reikia panaudoti lygti (5.14), tiksliau jos išraiškas, kai $z=0$ ir $z=H$. Taigi reikia ivvertinti, kad, esant šioms $z$ reikšmėms, integralai esantys lygtyje (5.14), igauna konkrečias reikšmes (Birger 1990):

$$
\int_{0} q_{r}(z)=0, \quad \quad \int_{0}^{H} q_{r}(z)=F_{r} .
$$

Panaudojus (5.20), iš lygties (5.14) gauname:

$$
q_{r}^{\prime}(0)=0, \quad q_{r}^{\prime}(H)=m_{r}^{2} F_{r}+\left(m_{t}^{2}-m_{r}^{2}\right) F_{o v} .
$$

Sulyginus pirmosios išvestinès $q_{r}^{\prime}(z)$ išraiškas, nustatytas iš (5.19), kai $z=0$ ir $z=H$, su atitinkamomis išraiškomis (5.21), gaunamos dvi lygtys. Iš šių lygčių nustatyti koeficientai $C_{r}$ ir $D_{r}$ yra tokie:

$$
C_{r}=0, \quad D_{r}=\frac{m_{r}\left(F_{r}-F_{o v}\right)}{\sinh \left(m_{r} H\right)} .
$$

Diferencialinès lygties (5.15) sprendinio galutinè išraiška atrodo taip:

$$
q_{r}(z)=\frac{m_{r}\left(F_{r}-F_{o v}\right)}{\sinh \left(m_{r} H\right)} \cosh \left(m_{r} z\right)+\frac{m_{t} F_{o v}}{\sinh \left(m_{t} H\right)} \cosh \left(m_{t} z\right) .
$$

Veikiant išorinei jègai $F_{r}$, smeigès šerdies ašinès jègos pasiskirstymo išraiška gaunama integruojant:

$$
Q_{r}(z)=\int_{0}^{z} q_{r}(z)=\frac{m_{r}\left(F_{r}-F_{o v}\right)}{\sinh \left(m_{r} H\right)} \sinh \left(m_{r} z\right)+\frac{m_{t} F_{o v}}{\sinh \left(m_{t} H\right)} \sinh \left(m_{t} z\right) .
$$

Lygties (5.23) galiojimą riboja sąlyga $F_{r} \leq F_{o v}$, nes jègai $F_{r}$ viršijus $F_{o v}$ reikšmę, vijų deformavimas tęsiasi pagal pirmają tiesę (punktyras $5.3 \mathrm{c}$ pav.) ir ji sąlygoja paslankumas $\gamma_{f}$.

Pirmasis sumos narys lygtyje (5.23) yra neigiamas ir jo didumas priklauso nuo paslankumo $\gamma_{r}$ reikšmès. Antrasis sumos narys lygtyje (5.23) yra tapatus lygčiai (5.11), o jo didumas priklauso nuo paslankumo $\gamma_{f}$ reikšmės. Kadangi $\gamma_{r}<\gamma_{f}$, didejjant $z$ reikšmei, neigiamas narys didejja greičiau už teigiamo nario reikšmes. Iš viso to seka: kol sąlyga $F_{r}<F_{o v}$ tenkinama, vijų apkrova pavojingoje zonoje, ties veržlès atrama gerokai sumažėja palyginus su vijų apkrovomis šioje zonoje, kurios čia veikia tuo atveju, kai pirmojo jungties apkrovimo nebūna. 
Lygtis (5.23) rodo, kad esant jègu lygybei $F_{r}=F_{o v}$, pirmasis jos narys yra lygus nuliui ir vijų apkrovos išraiška igauna tą pati pavidalą (5.11), kuris nustato vijų apkrovas, kurios atsiranda jungti apkraunant pirmą kartą. Iš čia seka išvada apie vijų apkrovos grižtamumą, kuri sako, kad tuo atveju, kai maksimalios ašinès jègos apkraunant jungti pirmaji ir antraji kartą yra vienodo didumo $\left(F_{r}=F_{o v}\right)$, apkrovus jungti antraji karta, apkrovos pasiskirstymas vijose grižta ị tą patị lygi, kurị vijos turejo apkraunant pirmąkart.

Cikliškai lenkiamos jungties atveju, vijų nukrovimas ir kartotinis apkrovimas yra neatsiejama proceso dalis. Todèl, esant tam tikroms sąlygoms, vijų apkrovos grižtamumo galima tikètis ir kartotinai lenkiamoje jungtyje.

\subsubsection{Plastiško išankstinio perkrovimo modelis}

Matematiniam modeliui supaprastinti nagrinejama tempiama srieginè jungtis, kurioje vijos sukibusios visu profiliu visame jungties ilgyje $H \mathrm{t}$. y. jungties įviju itakos nepaisoma. Sriegine jungtis pirmą kartą apkraunama ašine jèga $F=F_{o v}$. Po nukrovimo, antrą kartą sriegine jungtis apkrauta iki $F=F_{r}<F_{o v}$. Srieginę jungtị sudaro du ruožai: $H_{1}$ ir $H_{2}$ (5.4 pav.).

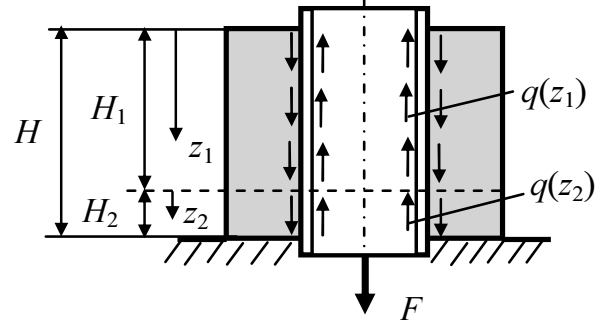

$a$

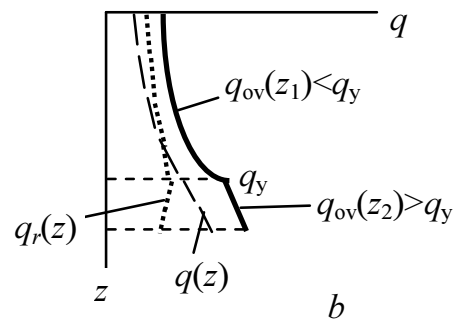

5.4 pav. Srieginès jungties perkrovimas

Fig. 5.4. Overloading of threaded connection

Vijų deformavimo pirmame ir antrame ruože schemos, veikiant perkrovimo jègai $F_{o v}$ ir kartotinei jègai $F_{r}<F_{o v}$, parodytos 5.5 paveiksle.

Atliekant išankstini perkrovimą, pirmajame ruože vijų apkrova neviršija vijų takumo jègos intensyvumo reikšmès $-q_{o v}\left(z_{1}\right) \leq q_{y}$, o antrajame ruože vijų apkrova šią reikšmę viršija $-q_{o v}\left(z_{2}\right) \geq q_{y}$ (4.1 pav.). Po perkrovimo antrą kartą apkrovus jungti (iki $F_{r}<F_{o v}$ ), susidariusi vijų apkrovu pasiskirstymą 5.4 paveiksle vaizduoja kreivè $q_{r}(z)$. Jeigu jungtis apkraunama iprastu būdu iki $F_{r}-$ be išankstinio perkrovimo, vijų apkrovų pasiskirstymą 5.4 paveiksle vaizduoja kreivè $q(z)$, kurios reikšmès pavojingoje jungties srityje (ties atrama) yra mažesnès už $q_{r}(z)$ reikšmes. 

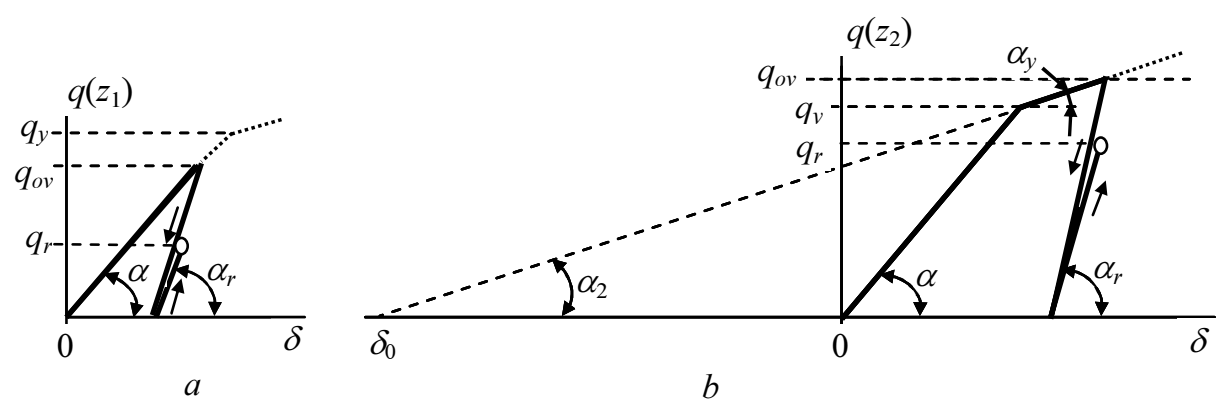

5.5 pav. Sriegio vijų deformavimo schema: ruože $H_{1}$ (a), ruože $H_{2}$ (b)

Fig. 5.5. Deflection schemes of thread turns: in segment $H_{1}(\mathrm{a})$, in segment $H_{2}$ (b)

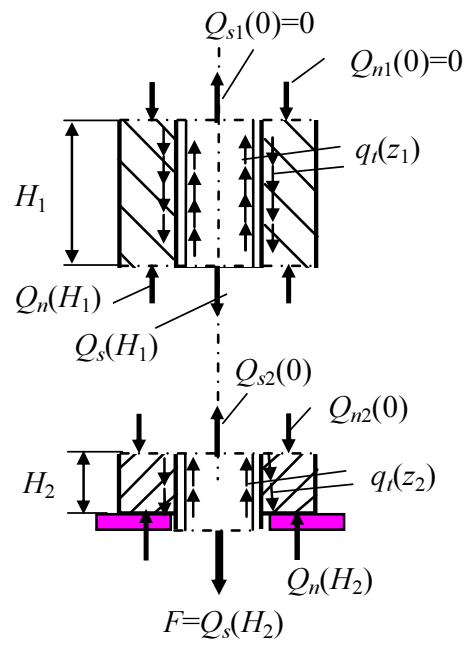

5.6 pav. Srieginès jungties kraštinès sąlygos

Fig. 5.6. Boundary conditions of threaded connection

Modeliavimui reikalingos dviejų ruožų jungties kraštinės sąlygos parodytos 5.6 paveiksle ir detaliau 5.1 lenteleje. 
5.1 lentelè. Dviejų ruožų jungties kraštinès sąlygos

Table 5.1. Boundary conditions

\begin{tabular}{|c|c|c|c|}
\hline $\begin{array}{c}\text { Išoriné apkrova } \\
F\end{array}$ & $Q_{s}\left(H_{1}\right)=Q_{n}\left(H_{1}\right)$ & $Q_{s 2}(0)=Q_{n 2}(0)$ & $Q_{s}\left(H_{2}\right)=Q_{n}\left(H_{2}\right)=F$ \\
\hline$F_{o v}$ & $Q_{s o v}\left(H_{1}\right)$ & $Q_{s o v, 2}(0)$ & $Q_{s o v}\left(H_{2}\right)=F_{o v}$ \\
\hline$F_{r}$ & $Q_{s r}\left(H_{1}\right)$ & $Q_{s r, 2}(0)$ & $Q_{s r}\left(H_{2}\right)=F_{r}$ \\
\hline
\end{tabular}

Vijų apkrovų pasiskirstymo pirmajame ruože $H_{1}$ skaičiavimui, veikiant jègai $F_{r}$ po išankstinio perkrovimo jèga $F_{o v}$, tinka lygtis (5.23). Taikant kraštinių sąlygu žymèjimus, pateiktus 5.1 lentelèje, ši lygtis igauna toki pavidalą:

$$
q_{r}\left(z_{1}\right)=\frac{m_{r}\left[Q_{s r}\left(H_{1}\right)-Q_{s o v}\left(H_{1}\right)\right]}{\sinh \left(m_{r} H_{1}\right)} \cosh \left(m_{r} z_{1}\right)+\frac{m_{t} Q_{s o v}\left(H_{1}\right)}{\sinh \left(m_{t} H_{1}\right)} \cosh \left(m_{t} z_{1}\right) .
$$

Antrajame jungties ruože $H_{2}$ (kuriame galioja $\gamma_{y}=\operatorname{ctg} \alpha_{y}$ ) vijų apkrovos pasiskirstymas, kuris susidaro po išankstinio perkrovimo jèga $F_{o v}$, skaičiuojamas pagal tokią formulę (Speičys, Krenevičius 1987)

$$
\begin{gathered}
q_{o v}\left(z_{2}\right)=\left[U_{2} \sinh \left(m_{y} z_{2}\right)+V_{2} \cosh \left(m_{y} z_{2}\right)\right], \quad m_{y}^{2}=\beta / \gamma_{y}, \\
U_{2}=m_{y} Q_{s o v, 2}(0), \quad V_{2}=q_{y} .
\end{gathered}
$$

Nežinomieji $H_{2}=H-H_{1}$ ir $Q_{s o v, 2}(0)$ randami iš lygčių sistemos:

$$
Q_{s o v, 2}(0)=q_{y} \frac{\tanh \left[m_{t}\left(H-H_{2}\right)\right]}{m_{t}}, \quad q_{y}=\frac{m_{y}\left[F_{o v}-Q_{s o v, 2}(0) \cosh \left(m_{y} H_{2}\right)\right]}{\sinh \left(m_{y} H_{2}\right)} .
$$

Antrajame jungties ruože $H_{2}$ liekamieji vijų ilinkiai, kurie atsiranda po išankstinio perkrovimo, yra didesni už atitinkamus įlinkius ruože $H_{1}$. Naudojant vijų deformavimo schemą (5.5 b pav.), liekamieji vijų ilinkiai aprašomi tokia lygtimi:

$$
\begin{aligned}
& w\left(z_{2}\right)=\left(\gamma_{y}-\gamma_{r}\right) q_{o v}\left(z_{2}\right)-\delta_{0}= \\
& =\left(\gamma_{y}-\gamma_{r}\right)\left[U_{2} \sinh \left(m_{y} z_{2}\right)+V_{2} \cosh \left(m_{y} z_{2}\right)\right]-\delta_{0}
\end{aligned}
$$

Tam, kad gauti išraišką aprašančią, kaip pasikeičia vijų apkrova $q_{r}\left(z_{2}\right)$ po antrojo apkrovimo, yra panaudota papildyta Birgerio srieginės jungties elementų išilginių poslinkių darnos lygtis, kurioje ịvertintas vijų liekamujjų ilinkių didumas. Sios lygties bendriausias pavidalas yra toks:

$$
\Delta z_{s, 2}+\left|\Delta z_{n, 2}\right|=\left[\delta\left(z_{2}\right)-\delta_{2}(0)\right]+\left[w\left(z_{2}\right)-w_{2}(0)\right],
$$


čia $\Delta z_{s, 2} ;\left|\Delta z_{n, 2}\right|$ - smeigès šerdies ir veržlès sienelès skerspjūvių $z_{2}$ išilginiai poslinkiai.

Detaliau išreikšta išilginių poslinkių darnos lygtis yra tokia:

$$
\begin{aligned}
& \int_{0}^{z}\left[\frac{Q_{s r, 2}(0)+\int_{0}^{z} q_{r}\left(z_{2}\right) d z_{2}}{E_{s} A_{s}}\right] d z_{2}+\int_{0}^{z}\left[\frac{\left|Q_{n r, 2}(0)+\int_{0}^{2} q_{r}\left(z_{2}\right) d z_{2}\right|}{E_{n} A_{n}}\right] d z_{2}= \\
& =\left[\gamma_{r} q_{r}\left(z_{2}\right)+w\left(z_{2}\right)\right]-\left[\gamma_{r} q_{r, 2}(0)+w_{2}(0)\right]
\end{aligned}
$$

Po lygties (5.31) dviejų diferecijavimų paeiliui gaunamos tokios išraiškos:

$$
\begin{gathered}
\beta \int_{0}^{z} q_{r}\left(z_{2}\right)=\gamma_{r} q_{r}^{\prime}\left(z_{2}\right)+w^{\prime}\left(z_{2}\right), \\
q_{r}^{\prime \prime}\left(z_{2}\right)-m_{r}^{2} q_{r}\left(z_{2}\right)=\left(m_{y}^{2}-m_{r}^{2}\right)\left[U_{2} \sinh \left(m_{y} z_{2}\right)+V_{2} \cosh \left(m_{y} z_{2}\right)\right] .
\end{gathered}
$$

Diferencialinès lygties (5.33) sprendini $q_{r}\left(z_{2}\right)$ sudaro bendrasis ir atskiras sprendiniai. Bendrojo sprendinio $\bar{q}_{r}\left(z_{2}\right)$ forma yra tokia pati, kokią turi lygti (5.33) atitinkančios homogeninès lygties sprendinys. Atskiras sprendinys $\overline{\bar{q}}_{r}\left(z_{2}\right)$ turi būti ieškomas formoje, kuri atitinka dešinę diferencialinès lygties (5.33) pusę. Užrašyti šie sprendiniai atrodo taip

$$
\begin{gathered}
q_{r}\left(z_{2}\right)=\bar{q}_{r}\left(z_{2}\right)+\overline{\bar{q}}_{r}\left(z_{2}\right), \\
\bar{q}_{r}\left(z_{2}\right)=C_{r, 2} \sinh \left(m_{r} z_{2}\right)+D_{r, 2} \cosh \left(m_{r} z_{2}\right), \\
\overline{\bar{q}}_{r}\left(z_{2}\right)=A_{2} \sinh \left(m_{y} z_{2}\right)+B_{2} \cosh \left(m_{y} z_{2}\right) .
\end{gathered}
$$

Pagal diferencialinių lygčių sprendimo taisykles funkcijai $q_{r}\left(z_{2}\right)$ nustatytu koeficientų išraiškos yra tokios:

$$
\begin{gathered}
A_{2}=m_{y} Q_{s o v, 2}(0), \quad B_{2}=q_{y}, \\
C_{r, 2}=m_{r}\left[Q_{s r, 2}(0)-Q_{s o v, 2}(0)\right], \\
D_{r, 2}=\left\{m_{r} F_{r}-m_{r} Q_{s o v, 2}(0)\left[\cosh \left(m_{y} H_{2}\right)+\cosh \left(m_{r} H_{2}\right)\right]-\right. \\
\left.-\left(m_{r} / m_{y}\right) q_{y} \sinh \left(m_{y} H_{2}\right)-m_{r} Q_{s r, 2}(0) \cdot \cosh \left(m_{r} H_{2}\right)\right\} / \sinh \left(m_{r} H_{2}\right)
\end{gathered}
$$

Veikiant išorinei jègai $F_{r}$, smeigès šerdies ašinès jègos pasiskirstymo ruože $\mathrm{H}_{2}$ išraiška gaunama integruojant:

$$
\begin{aligned}
& Q_{r}\left(z_{2}\right)=Q_{s r, 2}(0)+\int_{0}^{z} q\left(z_{2}\right) d z_{2}= \\
& =\left[A_{2} \cosh \left(m_{y} z_{2}\right)+B_{2} \sinh \left(m_{y} z_{2}\right)\right] / m_{y}+\left[C_{r, 2} \cosh \left(m_{r} z_{2}\right)+D_{r, 2} \sinh \left(m_{r} z_{2}\right)\right] / m_{r}
\end{aligned}
$$


Vietiniai įtempiai smeigès vijų įdubose, esančiose abiejuose jungties ruožuose, apskaičiuojami pagal formulę (3.86), kuri pateikta trečiame skyriuje.

\subsubsection{Skaičiavimo rezultatai}

Vijų apkrovų, ašinių iražųu ir vietinių itempių persiskirtymo po jungties išankstinio perkrovimo skaičiavimas atliktas jungčiai M20 $\times 2,5$ pagamintai iš plieno 25X1MФ. Skaičiavimai rezultatai gauti naudojant dvi perkrovimo jègos reikšmes: $\quad F_{o v}=0,84 R_{\mathrm{y}} \cdot A_{s}=0,84 F_{\mathrm{y}} \quad\left(8.7\right.$ pav.) ir $\quad F_{o v}=R_{\mathrm{y}} \cdot A_{s}=F_{\mathrm{y}} . \quad(8.8$ pav.). Plieno ir vijų deformavimo rodiklių reikšmès yra pateiktos 1 skyriuje.

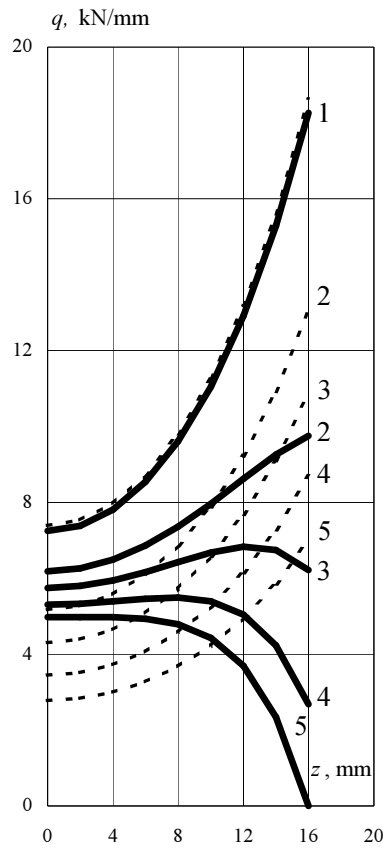

a

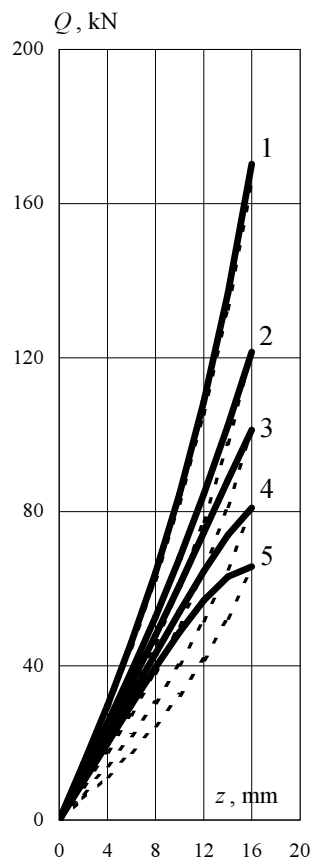

b

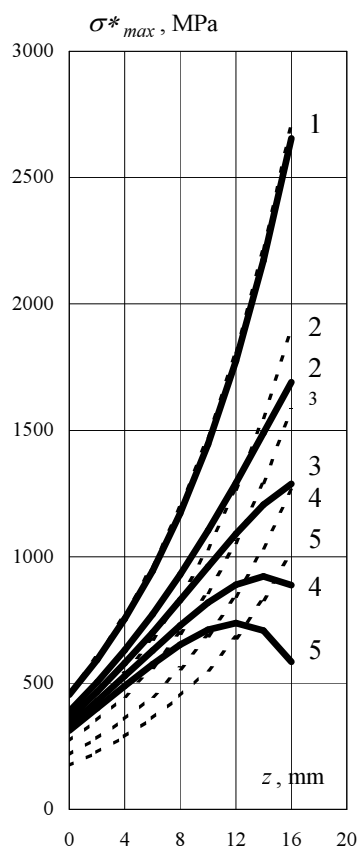

$\mathrm{c}$

5.7 pav. Vijų apkrovų (a), ašiniu iražų (b) ir vietinių įtempių (c) persiskirstymas smeigèje M20 $\times 2,5$, veikiant jègai $F_{r}$ po išankstinio perkrovimo jèga $F_{o v}=0,84 F_{\mathrm{y}} ;$ - su perkrovimu, - - - - be perkrovimo

Fig. 5.7. Load intensities on turns (a) axial loads (b) and alternating local stresses (c) in stud $\mathrm{M} 20 \times 2.5$ at $F_{r}$ after overloading by force $F_{o v}=0,84 F_{\mathrm{y}}$;

— with overloading, - - - without overloading 
Tuo atveju, kai jungti veikia jèga $F_{r}$ po perkrovimo su $F_{o v}=0,84 F_{\mathrm{y}}$, pavojingosios vijos plastiškai nesideformuoja (jungti sudaro vienas ruožas). Šiuo atveju skaičiavimai atlikti pagal metodiką pateiktą 5.2.1. skyriuje. Kitu atveju, kai $F_{o v}=F_{\text {y }}$, skaičiavimai atlikti pagal metodiką pateiktą 5.2.2. skyriuje.

5.7 paveiksle skaitinès nuorodos žymi antrojo apkrovimo jègos $F_{r}$ (pridètos po perkrovimo) reikšmes: $1-F_{r}=F_{o v}=0,84 F_{\mathrm{y}}, 2-F_{r}=0,6 F_{\mathrm{y}}, 3-F_{r}=0,5 F_{\mathrm{y}}$, $4-F_{r}=0,4 F_{\mathrm{y}}, 5-F_{r}=0,32 F_{\mathrm{y}} .5 .7$ ir 5.8 paveiksluose punktyrinemis linijomis parodyti jèga $F$ veikiamos jungties apkrovu ir vietinių itempių pasiskirstymai, kurie susidarytu jungtyje, kuri išankstinio perkrovimo nepatyrè. Jègų $F$ reikšmès yra lygios panaudotoms jègų $F_{r}$ reikšmėms. 5.7 paveiksle jègos $F$ reikšmès yra tokios: $1-F=0,84 F_{\mathrm{y}}, 2-F=0,6 F_{\mathrm{y}}, 3-F=0,5 F_{\mathrm{y}}, 4-F=0,4 F_{\mathrm{y}}, 5-$ $F=0,32 F_{\mathrm{y}}$.

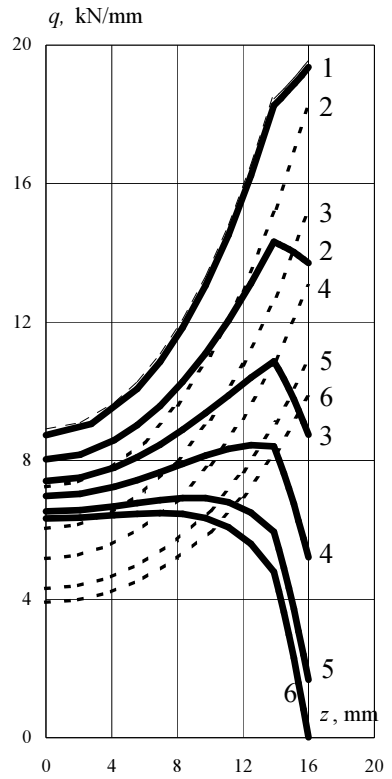

a

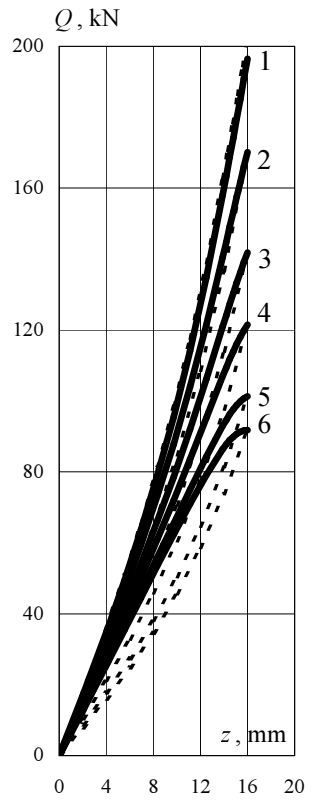

$\mathrm{b}$

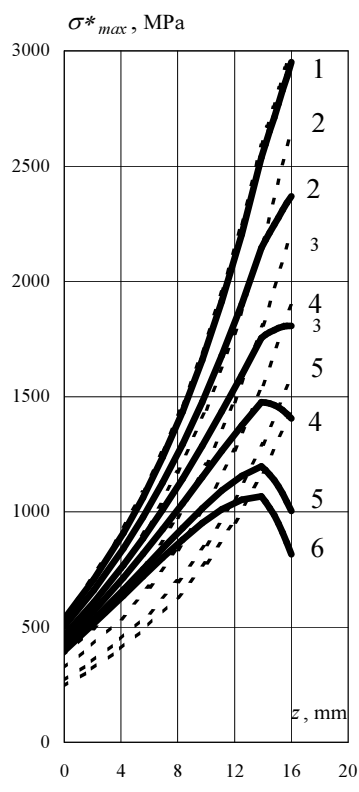

c

5.8 pav. Vijų apkrovų (a), ašinių ịažų (b) ir vietinių itempių (c) persiskirstymas smeigèje M20 $\times 2,5$, veikiant jègai $F_{r}$ po išankstinio perkrovimo jèga $F_{o v}=F_{\mathrm{y}}$;

— su perkrovimu, - - - - be perkrovimo

Fig. 5.8. Load intensities on turns (a) axial loads (b) and alternating local stresses (c) in stud M20 $\times 2.5$ at $F_{r}$ after overloading by force $F_{o v}=F_{\mathrm{y}}$;

- with overloading, - - - without overloading 
5.8 paveiksle skaitinès nuorodos, žyminčios antrojo apkrovimo jègos $F_{r}$ (pridètos po perkrovimo) reikšmes, yra tokios: $1-F_{r}=F_{o v}=F_{\mathrm{y}}, 2-F_{r}=0,84 F_{\mathrm{y}}$, $3-F_{r}=0,7 F_{\mathrm{y}}, 4-F_{r}=0,6 F_{\mathrm{y}}, 5-F_{r}=0,5 F_{\mathrm{y}}, 6-F_{r}=0,45 F_{\mathrm{y}}$. Jègų $F$ reikšmès (atitinkačios punktyrines linijas) 5.8 paveiksle yra lygios panaudotoms jègų $F_{r}$ reikšmèms.

Skaičiavimų rezultatai rodo, kad naudojant išankstini srieginės jungties perkrovima, viju apkrovos ir vietiniai itempiai sriegyje pavojingoje smeigès srityje (arti jungties atramos) sumažeja. Šis efektas yra didesnis, kai jungtis iš anksto perkraunama didesne jèga, dèl kurios pradinès vijų poros (esančios arti atramos) deformuojasi plastiškai. Kuo mažesnè pakartotinè jèga $F_{r}$ yra už perkrovimo jègą $F_{o v}$, tuo daugiau sumažeja vietiniai įtempiai smeigès sriegyje pavojingoje jungties srityje.

Čia reikia pastebèti, kad perkrovimo jèga $F_{o v}$ neturètų viršyti smeigès takumą sukeliančios jègos $F_{y}$, nes tokiu atveju smeigès šerdis pradeda deformuotis plastiškai ir smeigès pavojingujų vijų vietiniai įtempiai didejja.

Dèl išankstinio perkrovimo atsirandančio smeigès sriegio $(M 20 \times 2,5)$ vietinių itempių sumažèjimo rodikliai pateikti 5.2 lentelèje.

5.2 lentelè. Maksimalių vietinių sąlyginių įtempių sumažèjimas smeigès sriegyje

Table 5.2. Decreasing of maximum local stresses in stud's thread

\begin{tabular}{|c|c|c|c|c|c|}
\hline \multicolumn{2}{|c|}{ Be išankstinio perkrovimo } & \multicolumn{4}{|c|}{ Išankstinio perkrovimo jèga $F_{o v}=0,84 F_{\mathrm{y}}$} \\
\hline$\frac{F}{F_{y}}$ & $\sigma_{s}^{*}$ & $\frac{F_{r}}{F_{y}}$ & $\frac{F_{o v}}{F_{r}}$ & $\sigma_{s, r}^{*}$ & $\frac{\sigma_{s}^{*}-\sigma_{s, r}^{*}}{\sigma_{s}^{*}} 100$ \\
\hline- & Мра & - & - & Mpa & $\%$ \\
\hline 0,84 & 2655 & 0,84 & 1 & 2655 & 0 \\
\hline 0,6 & 1896 & 0,6 & 1,4 & 1690 & 10,9 \\
\hline 0,5 & 1580 & 0,5 & 1,68 & 1289 & 18,4 \\
\hline 0,4 & 1264 & 0,4 & 2,1 & 922 & 27,1 \\
\hline 0,32 & 1017 & 0,32 & 2,625 & 738 & 27,4 \\
\hline \multicolumn{2}{|c|}{ Be išankstinio perkrovimo } & \multicolumn{4}{|c|}{ Išankstinio perkrovimo jèga $F_{o v}=F_{\mathrm{y}}$} \\
\hline$\frac{F}{F_{y}}$ & $\sigma_{s}^{*}$ & $\frac{F_{r}}{F_{y}}$ & $\frac{F_{o v}}{F_{r}}$ & $\sigma_{s, r}^{*}$ & $\frac{\sigma_{s}^{*}-\sigma_{s, r}^{*}}{\sigma_{s}^{*}} 100$ \\
\hline- & $\mathrm{MPa}$ & - & - & $\mathrm{MPa}$ & $\%$ \\
\hline 1 & 3012 & 1 & 1 & 3012 & 0 \\
\hline 0,84 & 2654 & 0,84 & 1,19 & 2370 & 10,7 \\
\hline 0,7 & 2212 & 0,7 & 1,43 & 1807 & 18,3 \\
\hline 0,6 & 1896 & 0,6 & 1,67 & 1463 & 22,8 \\
\hline 0,5 & 1580 & 0,5 & 2 & 1198 & 24,2 \\
\hline 0,45 & 1432 & 0,45 & 2,22 & 1067 & 25,5 \\
\hline
\end{tabular}


Iš 5.2 lentelès duomenų matyti, kad naudojant išankstinị perkrovimą maksimalius vietinius itempius smeigès sriegyje galima sumažinti 10-25\%.

\subsection{Penktojo skyriaus išvados}

1. Pasiūlytas cikliškai lenkiamos jungties ilgaamžiškumo padidinimo būdas (jungties pozicionavimo būdas) realizuojamas eksploatavimo metu periodiškai keičiant jungties padètị lenkimo plokštumos atžvilgiu.

2. Naudojant jungties pozicionavimo būda, cikliškai lenkiamos srieginès jungties ilgaamžiškumą iki plyšio atsiradimo galima padidinti iki 2 kartų.

3. Pasiūlytas smeigès sriegio maksimalių vietinių itempių sumažinimo būdas realizuojamas išankstiniu srieginès jungties perkrovimu, kuris remiasi eksperimentiškai nustatytu žymių liekamujų vijų illinkių atsiradimo faktu, pasireiškiančiu po srieginès jungties nukrovimo.

4. Naudojant jungties išankstini perkrovimą maksimalius sąlyginius vietinius įtempius smeigès sriegyje galima sumažinti 10-25\%.

5. Smeigès sriegio vietinių itempių sumažèjimas yra didesnis, kai jungtis iš anksto perkraunama tokio didumo jèga, dèl kurios pradinès vijų poros (esančios arti jungties atramos) deformuojasi plastiškai. 



\section{Bendrosios išvados}

1. Literatūros šaltinių analizè rodo, kad skaičiuojant lenkiamų srieginių jungčiu mažaciklị ilgaamžiškumą vietiniai itempiai smeigès sriegio įdubose nustatomi nevertinant apkrovos pasiskirstymo sriegio vijose ir neanalizuojant pavojingojo skerspjūvio apkrovimo.

2. Eksperimentinès vijų paslankumo $\gamma_{r}$ reikšmès, nustatytos atlikus vienos vijuc poros tempimo bandymus ją nukraunant ir kartotinai apkraunant, yra daugiau kaip 2 kartus didesnès (apytiksliai 2-2,4 karto) už vijų paslankumo $\gamma_{f}$ reikšmes, nustatytas pagal pirmojo apkrovimo tiesinę vijų deformavimo diagramos dali.

3. Sudarytos lenkiamos srieginès jungties elementu poslinkių suderinamumo diferencialinès lygtys susieja smeigès šerdies, veržlès sienelès ir sukibusių vijų porų poslinkius.

4. Diferencialiniu lygčių sprendiniu - vijų apkrovų ir vidinių lenkimo momentu - skaitinès reikšmès, nustatytos analitiniu ir Rungès - Kutto metodais visame srieginès jungties ilgyje, skiriasi nežymiai, ne daugiau kaip $1 \%$.

5. Sudarytas trijų ruožų srieginès jungties modelis yra matematiškai racionalesnis už daugiaruoži modeli, taikant juos ciklinio necentrinio tempimo atvejams, kai pusvijų, esančių priešingose jungties pusėse, apkrovimo pobūdis visuomet yra vienodas - jos apkraunamos arba nukraunamos. Daugiaruožis srieginès jungties modelis, sudarytas po įveržimo lenkiamų jungčiu atvejui, ịver- 
tina skirtingą pusvijų, esančių priešingose nuo neutraliosios plokštumos jungties pusèse, apkrovimo pobūdi pirmajame pusciklyje, kai vienoje pusèje jos apkraunamos, o kitoje nukraunamos ir vienodą šių pusvijų apkrovimo pobūdi pasikartojančiuose puscikliuose.

6. Lyginant necentriškai tempiamos smeigès sriegio maksimaliu vietinių itempių reikšmes, apskaičiuotas taikant sudarytą analitini modelį, su eksperimentinėmis reikšmėmis, gautomis fototamprumo metodu (Burguete ir Patterson, 1994), nustatytas šių reikšmių skirtumas sudaro apie $5 \%$.

7. Lenkiamų srieginių jungčių mažaciklio ilgaamžiškumo reikšmès, apskaičiuotos pagal modifikuotą norminę formulę, taikant apkrovos pasiskirstymo sriegyje duomenis, yra 2-5 kartus didesnès už ilgaamžiškumo reikšmes, apskaičiuotas pagal normas (RF stiprumo skaičiavimo normos 1989). Jos yra artimesnès eksperimentinèms ilgaamžiškumo reikšmèms ir jų neviršija.

8. Taikant periodiškus jungties padèties pakeitimus lenkimo plokštumos atžvilgiu, cikliškai lenkiamos srieginès jungties ilgaamžiškumą iki plyšio atsiradimo galima padidinti iki 2 kartų. Naudojant jungties išankstinị perkrovimą maksimalius sąlyginius vietinius ittempius smeigès sriegyje galima sumažinti apie $10-25 \%$. 


\section{Literatūra ir šaltiniai}

ASME Code. 1995. ASME Boiler and Pessure Vessel Code, Sec. III, Rules for construction of Nuclear Power Plant Components, Div. I., Subsec. NB. 87-92.

ASME Code. 1995. ASME Boiler and Pessure Vessel Code, Sec. III, Rules for construction of Nuclear Power Plant Components, Div. I., Appendices. 6-12.

Atkočiūnas, J.; Nagevičius, J. 2004. Tamprumo teorijos pagrindai. Vadovèlis. Vilnius : Technika. 528.

Bazaras, Ž. Investigation of the construction of probabilistic low cycle fatigue design curves at strain cycling. Transport Vol. XX, No 5. 195-203.

Barauskas, R; Kačianauskas, R., Belevičius, R. 2004. Baigtinių elementų metodo pagrindai : vadovèlis. Vilnius: Technika. 612.

Bulatović, R.; Jovanović, J. 2000. An Analysis of the Mathematical Models in the Deformation Process of Eccentrically Loaded Bolts. FACTA UNIVERSITATIS Series: Mechanical Engineering Vol. 1, No 7. 789.

Bražènas, A. Strength and low cycle fatigue life of mechanically heterogeneous welded joints. Kaunas: Technologija. 50.

Bražènas, A. 1999. Damage accumulation under low cycle loading when strains are constrained. Mechanika No 4(19). Kaunas: Technologija. 5-11.

Bergmann, M.; Bruzek, B.; Lang, H. 2010. Numerical studies of microstructurally optimized bolts with graded grain size. Materials and Design 31. 1438-1443 
Burguete, R. L.; Patterson, E. A. 1994. The effect of bending on the normalized stress at roots of threaded connectors. J. OMAE, ASME 116(3): 163-166.

Burguete, R. L.; Patterson E. A. 1995. The effect of eccentric loading on the stress distribution in thread roots. Fatigue Fracture. Engineering Materials. Structures. Vol. 18, No. 11. 1333-1341.

Биргер, И.А.; Иосилевич, Г.Б. 1973. Резьбовые соединения. М. Машиностроение. 256.

Blaer, I. L. 2007. Threaded joints. Russian Engineering Research. Vol. 27, No. 10. 661668.

Bickford, J. H. 1995. An Introduction to the Design and Behavior of Bolted Joints. Marcel Dekker. New York. 565-601.

Биргер, И. А.; Иосилевич, Г. Б. 1990. Резьбовые и фланцевые соединения. Москва: Машиностроение. 365.

Chen, H. W.; Lee, S. S. 1995. Numerical and experimental failure analysis of composite laminates with bolted joints under bending loads, J. Composite Mater., Vol. 29, No. 1, pp. 15-36.

Cook, R.; Climont, W. 1962. The influence of screw forming methods on the fatigue strength of large bolts. Machinery, No. 21. 86-90.

Daniūnas, A.; Urbonas, K. 2007. Characteristics of the semi-rigid bolted steel joints under bending and axial forces and its influence on the frame behaviour. The 9th int. conf. May 16-18, 2007, Vilnius. Selected papers "Modern building materials, structures and techniques": Vol. 2. Vilnius: Technika, 512-516.

Daniūnas, A.; Urbonas, K. 2008. Analysis of the steel frames with the semi-rigid beamto-beam and beam-to-column knee joints under bending and axial forces. Engineering Structures Vol. 30, 11. Oxford : Elsevier. 3114-3118.

Daunys, M. 1989. Influence of Low Cycle Nonstationary Loading to Strength and Durability. 256.

Daunys, M.; Rimovskis, S. 2002. Analysis of low cycle loading characteristics at pure bending. Mechanika No 5(37). Kaunas. Technologija. 5-9.

Dragoni, E. 1997. Effect of thread pitch on the fatigue strength of steel. Proc. Imech. E., 211. 591-600.

Dragoni, E. 2011. Castagnetti D. Concentration of shear stresses in shallow periodic notches. Journal of Strain Analysis, Vol. 46. 1-8.

Dragoni, E. 1994. Effect of Thread Pitch and Frictional Coefficient on the Stress Concentration in Metric Nut-Bolt Connections. Journal of Mechanics and Arctic Engineering, Vol. 116. 21-27.

Dragoni, E. 1990. Effect of Nut Compliance on Screw Thread Load Distribution. Journal of Strain Analyzis, Vol. 25. 147-150. 
Fessler, H.; Jiong-Hua, Wang 1984. Stress analysis of some unsymmetric screwed connections. J. Strain Anal. 19, 111-119.

Fukuoka, T.; Takaki, T. 1998. Mechanical Behaviors of Bolted Joint in Various Clamping Configurations. Journal of Pressure Vessel Technology. August, Vol. 120. 226-231.

Hael Mughrabi. 2010. Fatigue, an everlasting materials problem - still en vogue. Procedia Engineering 2. 3-26.

Hobbs, J.W.; Burguete, R.L.; Patterson, E.A. 2003. Investigation into the effect of the nut thread run-out on the stress distribution in a bolt using the finite element method. Journal of Mechanical Design Vol. 125. 527-532.

Hase, R. 1980. Die beanspruchung der gewindegange im eingriff einer gewindeverbindung. Werkstatt und Betr. No. 4. 225-231.

Hobbs, J. W.; Burguete, R. L.; Heyes, P. F. 2000. The effect of eccentric loading on the fatigue performance of hightensile bolts. Internacional Jornal of Fatigue 22. $531-538$.

Honarmandi, P.; Zu, J. W.; Behdinan, K. 2005. Elasto-plastic fatigue life improvement of bolted joints and introducing FBI method. Mechanics Based Design of Structures and Mashines, 33. 311-330.

Horstemeyer, M.; Farkas, D.; Kim, S.; Tang, T.; Portiriche, G. 2010. Nanostructurally small cracks (NSC): A review on atomistic modeling of fatigue. International Journal of Fatigue 32. 1473-1502.

Izumi, S.; Yokoyama, T.; Iwasaki, A.; Sakai, S. 2005. Three-Dimensional Finite Element Analysis of Tightening and Loosening Mechanism of Threaded Fastener. Engineering Failure Analysis, Vol. 12. 604-615.

Иосилевич, Г. Б. 1981. Концентрация напряжений и деформаций в деталях машин. М. Машиностроение. 224.

Yoshimoto, I.; Maruyama, K.; Hongo, K.; Sasaki, T. 1979. On improvement of fatigue strength on high strength bolts. Bull. P.M.E. (T.L.T.), No. 43. 9-17.

Yazawa, S.; Hongo, K. 1988. Distribution of load in screw thread of a bolt-nut connection subjected to tangential forces and bending moments. JSME International Journal, Series I, Vol. 31, No. 2. 174-180.

Krenevičius, A.; Leonavičius, M. 1998. Srieginių jungčių M16 įveržimas ir atsparumas mažacikliam lenkimui. Statyba. ISSN 1392-1525, No. 2(14). Vilnius: Technika. 117123.

Krenevičius, A.; Leonavičius, M. 2008. Fatigue life prediction for threaded joint. Mechanika. ISSN 1392-1207, No 3(71). Kaunas: Technologija. 5-11.

Krenevičius, A.; Vislavičius, K.; Selivonec, J. 2004. Mechanika No. 6(50). Kaunas. Technologija. 5-11.

Knez, M.; Glodez, S.; Kramberger, J. 2009. Fatigue assesment of piston rod threaded end. Engineering Falure Analysis 16. 1977-1982. 
Kloos, K. H.; Schneider, W. 1984. Service durability of eccentrically stressed screw connections. VDI-Z 126(19). 741-750.

Korin I., Perez Ipiña J. 2011. Experimental evaluation of fatigue life and fatigue crack growth in a tension bolt-nut threaded connection. International Journal of Fatigue 33. $166-175$.

Komarova, T.; Kuzmin, Y.; Fedosov, V. 2007. Numerical investigation of stress concentration in alarge-diameter threaded connection. Chemical and Petrolium Engineering, Vol. 43 No. 5-6. 243-248.

Leonavičius, M.; Krenevičius, A. 1995. Prisitaikomumo ir atsparumo mažacikliam irimui varžtinėse jungtyse skaičiavimas. Mechanika. ISSN 1392-1207, No 1. Kaunas: Technologija. 30-32.

Leonavičius, M. 2000. Iveržtų ir cikliškai lenkiamų srieginių jungčių atsipalaidavimo analizè. Mechanika. ISSN 1392-1207, No 1(21). 5-9.

Leonavičius, M.; Krenevičius, A.; Šukšta, M.; Stupak, S; Bazaras, Ž. 2006. Experimental and analytical investigation of loosening and shakedown of the threaded joints. Indian Journal of Engineering, Materials Sciences. Vol. 13 October. 411-416.

Leonavičius, M. K. 1999. Srieginių jungčių ir jungiamų elementų atsparumas cikliniam irimui ir prisitaikomumas. Habilitacinis darbas. Vilnius: Technika. 96.

Liao, R.; Sun, Y.; Zhang, W. 2009. Nonlinear analysis of axial-load stress distribution for threaded connection. Chinese journal of mechanical engineering. Vol. 22, No. 6. $869-875$.

Manson S., Halford G. 1981. Practical implementation of the double linear damage approach for treating cumulative fatigue damage. International Journal of Fracture. 17. 169-192.

Medekšas, H.; Balina, V. S. 2006. Assessment of low cycle fatigue strength of nothed components. Materials and design, No. 27. 132-140.

Mathan G., N Siva Prasad. 2008. A study on the sealing performance of flange joints with gaskets under external bending using finite-element analysis. Proc. ImechE J. Process Mechanical Engineering, Part E: Vol., 222, 21-29.

Miner, M. 1945. Cumulative fatique damage.- Journal of Applied Mechanics. 1945, Vol. 67, No. 12. 159-164.

Makhutov, N. A. 1981. et al. Initiation and propagation mechanics of low cycle fatigue cracks in bolt. 5-th International Conference of Fracture Conues, Oxford, vol. 2. 605612.

Majzoobi, G. H.; Farrahi, G. H.; Habibi N. 2005. Experimental evaluation of the effect of thread pitch on fatigue life of bolts. Int. Journal of fatigue, No. 27. 189-196.

Махутов, Н. А.; Фролов, К. В.; Пригоровский, Н. И.; Стекольников, В. В. и др. 1987. Конструкции и методы расчёта водо-водяных энергетических реакторов. Москва: Наука. 232 с. 
Махутов, Н. А. 2005. Конструкционная прочность ресурс и техногенная безопасность, 2 ч. Новосибирск: Наука. 610.

Maruyama, K. 1974. Stress analysis of a nut-bolt joint by the finite element method and the copper electroplating method. Bull. Japan Soc. Mech. Engrs., 17. 442-450.

Malinovski, J. Z.; Ostapkowicz, J. 2001. On the behavior of a bolt-nut joint with plastically deformed thread.-Engineering Transactions V. 49, No 4. 189-196.

Motosh, N. I. 1975. Load Distribution on Threads of Titanium Tension Nuts and Steel Bolts. Journal of Engineering for Industry, February. 162-166.

Miller, D. L.; Marshek, K. M.; Naji, R. M. 1983. Determination of Load Distribution in a Threaded Connection, Mech. Mach. Theory 18(b). 421-431.

Muhammad-Tandur K. H., Magami I. A. 2008. Computing the stress concentration factor in bolted joint using FEM. International Journal of Applied Engineering Research. Vol. 3. 369-387.

Neuber, H.; Schmidt J.; Heckel H. 1975. Ein dauerschwingfestes Gewindeprofil. Konstruktion, 27, No. 11. 419-421.

Noda, Nao-Aki; XIAO, Yang; Kuhara, Masahiro 2011. The Reduction of Stress Concentration by Tapering Threads. Journal of Solid Mechanics and Materials. Engineering, Vol. 5, No. 8. 397-408.

Patterson, E. A.; Kenny, B. 1986. A Modification to the Theory for the Load Distribution in Conventional Nuts and Bolts. Strain Anal. 17-23.

Patterson, E.; Kenny, B. 1987. Stress analysis of some nut-bolt connections with modifications to the external shape of the nut. Journal of strain analysis Vol. 22, No 4. 187-193.

Patterson, E.; Kenny, B. 1986. The optimisation of the design of nuts with partly tapered threads. Journal of strain analysis Vol. 21, No 2. 77-84.

Peterson's Stress Concentration Factors. (1997). Editted by Pilkey, Walter D. John Wiley \& Sons Copyright. Knovel. 544.

Pyttel, B.; Schwerdt, D.; Berger, C. 2011. Very high cycle fatigue - Is there a fatigue limit? International Journal of Fatigue 33. 49-58.

RF normos. 1985. Нормы расчёта на прочность оборудования и трубопроводов атомных энергетических установок. Москва: Энергоатомиздат. 525.

Sopwith, D. G. 1948. The Distribution of Load in Screw Threads. Inst. Mech. Engrs. Appl. Mech. Proc. 373-383.

Shimotsuma, Y.; Inoue, H. 1973. Studies on screw-fastener on the statical characteristics of screw-threaded connections. Repts Kansai Univ., No. 14. 25-36.

Selivonec, J.; Krenevičius, A. 2004. Distribution of load in the threads. Mechanika. ISSN 1392-1207, No 2(46). Kaunas: Technologija. 21-26. 
Sawa,T.; Morohoshi, T.; Yamamoto, K. 1987. The characteristics of bolted joints subjected to external bending moments. JSME Int. J., 30(270). 2018-2026.

Sawa,T.; Morohoshi, T.; Yamamoto, K. 1987. The characteristics of bolted joints subjected to external bending moments. JSME Int. J., 30(270). 2018-2026.

Schmidt, H.; Neuper, M. 1997. On the elastostatic behaviour of an eccentrically tensioned L-joint with prestressed bolts, Stahlbau, Vol. 66, No. 3, pp. 163-168.

Snow, A. L.; Langer, B. F. 1967. Low cycle fatigue of large diameter bolts. Пер. с англ. Конструирование и технология машиностроения, Труды АОИМ, o 1. 63-74.

Seweryn, A.; Buczynski, A.; Szusta, J. 2008. Damage accumulation model for low cycle fatigue. International Journal of Fatigue 30. 756-765.

Venkatesan, S.; Kinzel, G. 2006. Reduction of stress concentration in bolt-nut connectors. Journal of mechanical design Vol. 128. 1337-1342.

Zhao, H. 1998. Stress Concentration Factors Within Bolt-Nut Connectors under ElastoPlastic Deformation.-Int. J. Fatigue., Vol. 20, No 9. 651-659.

Žiliukas, A. 1998. Two parametric elastic-plastic fracture criteria. ECF12: Fracture from Defects. Vol., I-III. 847-851.

Биргер, И. А.; Иосилевич, Г. Б. 1973. Резьбовые соединения. Москва: Машиностроение. 256 с.

Иосилевич, Г. Б. 1981. Концентрация напряжений и деформаций в деталях машин. М. Машиностроение. 224.

Спейчис, А. А.; Кренявичюс, А. И. 1987. Рапределение нагрузок по виткам резьбы с учетом пластических деформаций. Москва: Мащиноведение. № 2, с. 87-92.

Хейвуд, Р. Б. 1969. Проектирование с учетом усталости. Пер. с англ. Машиностроение. 504.

Якушев, А. И.; Мустаев, Р. Х.; Мавлютов, Р. Р. 1979. Повышение прочности и надёжности резьбовых соединений. М. Машиностроение. 215. 


\section{Autoriaus publikaciju disertacijos tema sąrašas}

\section{Straipsniai recenzuojamuose mokslo žurnaluose}

Krenevičius, A., Juchnevičius, Ž. 2009. Load distribution in the threaded joint subjected to bending, Mechanika 4(78): 12-16. ISSN 1392-1207 (Thomson ISI WEB of Science).

Krenevičius, A., Juchnevičius, Ž., Leonavičius, M. 2010. The model of bent threaded connection in three segments, Mechanika 4(84): 5-11. ISSN 1392-1207 (Thomson ISI WEB of Science).

Juchnevičius, Ž. Krenevičius, A. 2011. Fatigue life prediction for cyclically bent threaded connections, Mechanika 17(2): 113-119. ISSN 1392-1207 (Thomson ISI WEB of Science).

\section{Straipsniai kituose leidiniuose}

Krenevičius, A., Juchnevičius, Ž., Selivonec, J. 2008. Influence of reloading to load distribution in threaded connection, in Proceedings of the 13th international conference “MECHANIKA-2008”, Kaunas, Lithuania, 2008. Kaunas: Technologija, 172-175. ISSN 1822-2951 (Thomson ISI Proceedings). 
Juchnevičius, Ž., Krenevičius, A., Šukšta, M. 2009. The optimal distribution of loads between thread turns, in Proceedings of the 14th international conference “MECHANIKA-2009”, Kaunas, Lithuania, 2009. Kaunas: Technologija, 166-170. ISSN 1822-2951 (Thomson ISI Proceedings).

Juchnevičius, Ž., Krenevičius, A., Šukšta, M., Selivonec, J. 2010. Influence of constructional factors upon load distribution on turns at bending of threaded connection, in Proceedings of the 15th international conference "MECHANIKA-2010", Kaunas, Lithuania, 2010. Kaunas: Technologija, 204-209. ISSN 1822-2951 (Thomson ISI Proceedings).

Juchnevičius, Ž., Krenevičius, A. 2011. Analysis of load distribution and low cycle fatigue for bent threaded connections, in Proceedings of the 5th Annual International Traveling conference "ERIN - 2011", Tatranska Kotlina-High Tatras-Slovakia, 2011. Slovakia, Prešov: Harmony Apeiron Non-profit Civic Association, 243-256. ISBN 97880-89347-04-9.

Juchnevičius, Ž. Krenevičius, A. 2011. Influence of turns deformation features at unloading upon load distribution on turns at bending of the threaded connection, in Proceedings of the 16th international conference "MECHANIKA-2011", Kaunas, Lithuania, 2011. Kaunas: Technologija, 153-157. ISSN 1822-2951.

Krenevičius, A., Juchnevičius, Ž., Šukšta, M., Selivonec, J. 2011, Fatigue life increasing method for cyclically bent threaded connection, in Proceedings of the 16th international conference "MECHANIKA-2011", Kaunas, Lithuania, 2011. Kaunas: Technologija, 187-189. ISSN 1822-2951. 


\section{Priedai}

\section{A priedas. Viju poros tempimo bandymo rezultatai}

A.1 lentelė. Sriegio vijų poros M16 $\times 2$ deformavimo su nukrovimu rodikliai Table A.1. Deformation properties of turn pair at tension with unloading

\begin{tabular}{|c|c|c|c|}
\hline \multirow{2}{*}{ Eil. Nr } & $\gamma_{f}$ & $\gamma_{r}$ & $\gamma / \gamma_{r}$ \\
\cline { 2 - 4 } & $\mathrm{mm} /(\mathrm{kN} / \mathrm{mm})$ & $\mathrm{mm} /(\mathrm{kN} / \mathrm{mm})$ & - \\
\hline 1 & $3,98 \times 10^{-3}$ & $1,87 \times 10^{-3}$ & 2,12 \\
\hline 2 & $4,01 \times 10^{-3}$ & $1,93 \times 10^{-3}$ & 2,08 \\
\hline 3 & $4,00 \times 10^{-3}$ & $1,90 \times 10^{-3}$ & 2,11 \\
\hline 4 & $3,84 \times 10^{-3}$ & $1,90 \times 10^{-3}$ & 2,02 \\
\hline 5 & $4,09 \times 10^{-3}$ & $1,85 \times 10^{-3}$ & 2,22 \\
\hline 6 & $3,93 \times 10^{-3}$ & $1,81 \times 10^{-3}$ & 2,17 \\
\hline 7 & $3,95 \times 10^{-3}$ & $1,82 \times 10^{-3}$ & 2,17 \\
\hline 8 & $4,12 \times 10^{-3}$ & $1,83 \times 10^{-3}$ & 2,25 \\
\hline 9 & $3,90 \times 10^{-3}$ & $1,81 \times 10^{-3}$ & 2,15 \\
\hline 10 & $3,87 \times 10^{-3}$ & $1,89 \times 10^{-3}$ & 2,05 \\
\hline 11 & $4,07 \times 10^{-3}$ & $1,86 \times 10^{-3}$ & 2,18 \\
\hline 12 & $3,82 \times 10^{-3}$ & $1,91 \times 10^{-3}$ & 1,99 \\
\hline Pastaba: & \multicolumn{3}{|c|}{ pirmas nukrovimas tampriojoje srityje } \\
\hline
\end{tabular}




\section{B priedas. Iviju paslankumo funkcijos koeficientai}

Skaičiuojant vijų apkrovų ir iražǔ pasiskirstymą lenkiamoje jungtyje, turi būti matematiškai aprašytas vijų poros paslankumo kitimo dèsnis jungties kraštiniuose ruožuose $H_{1}$ ir $H_{3}$. Čia veržlès ir smeigès vijos yra sukibusios ne visu profiliu ir jų sukibimo gylis kinta. Tokia vijų pora toliau vadinama srieginès jungties ivija. Jungties ivijos paslankumas lenkiamai jungčiai aprašomas rodikline funkcija (3.9). Tai funkcija aproksimuojanti eksperimentinius duomenis (Selivonec, et al. 2004). Taikant ją srieginès jungties ruožams $H_{1}$ ir $H_{3}$, atitinkamų jungties ivijų paslankumų išraiškas galima užrašyti taip:

$$
\begin{aligned}
& \gamma\left(z_{1}\right)=V_{1} e^{u_{1} z_{1}}, \\
& \gamma\left(z_{3}\right)=V_{3} e^{u_{3} z_{3}} .
\end{aligned}
$$

Funkcijų (B.1) ir (B.2) pastovieji koeficientai nustatomi parašius nagrinèjamam ruožui dvi lygtis, kuriose naudojamos dvi žinomos paslankumo reikšmès. Viename ruožo krašte vijos sukibusios visu profiliu, todèl paslankumo rekšmè čia yra lygi $\gamma_{f}$. Pagal eksperimentinius duomenis ruožo $H_{1}$ arba $H_{3}$ viduryje paslankumas lygus $1,67 \gamma_{f}$.

Jungties ivvijos paslankumo kitimas ruože $H_{1}=P$ schematiškai parodytas B.1 paveiksle .

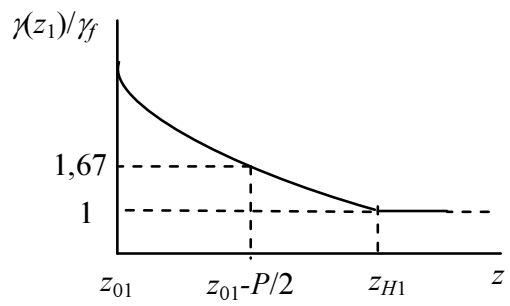

B1 pav. Jungties įvijos paslankumas ruože $H_{1}$

Fig. B1. Turn pair pliability in segment $H_{1}$ of threaded connection

Dvi lygtys, kurias reikia užrašyti ruožui $H_{1}$, panaudojant išraišką (B.1), yra tokios:

$$
\gamma\left(z_{H 1}\right)=V_{1} e^{u_{1} z_{H 1}}=\gamma_{f}, \quad \gamma\left(z_{H 1}-P / 2\right)=V_{1} e^{u_{1}\left(z_{H 1}-P / 2\right)}=1,67 \gamma_{f} .
$$

Tuomet:

$$
u_{1}=-\frac{\ln 1,67}{P / 2}, \quad V_{1}=\gamma_{f} \cdot e^{\frac{\ln 1,67}{P / 2} z_{H 1}} .
$$




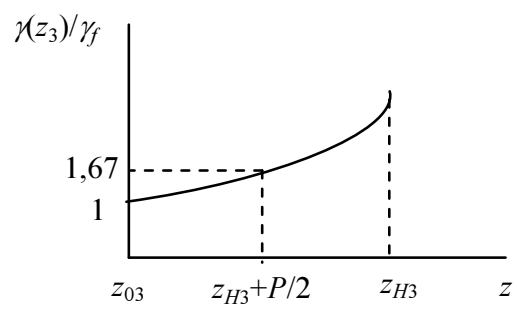

B.2 pav. Jungties ịvijos paslankumas ruože $H_{3}$

Fig. B.2. Turn pair pliability in segment $H_{3}$ of threaded connection

Jungties ivvijos paslankumo kitimas ruože $H_{3}=P$ schematiškai parodytas B.2 paveiksle . Dvi lygtys, kurias reikia užrašyti ruožui $H_{3}$, panaudojant išraišką (B.2), yra tokios:

$$
\gamma\left(z_{03}\right)=V_{3} e^{u_{3} z_{03}}=\gamma_{f}, \quad \gamma\left(z_{03}+P / 2\right)=V_{3} e^{u_{3}\left(z_{03}+P / 2\right)}=1,67 \gamma_{f} .
$$

Tuomet:

$$
u_{3}=\frac{\ln 1,67}{P / 2}, \quad V_{3}=\gamma_{f} \cdot e^{-\frac{\ln 1,67}{P / 2} z_{03}} .
$$

Apskaičiuotų ir eksperimentinių jungties M20×2,5 įvijos paslankumų palyginimas ruožui $H_{3}$ parodytas B.3 paveiksle.

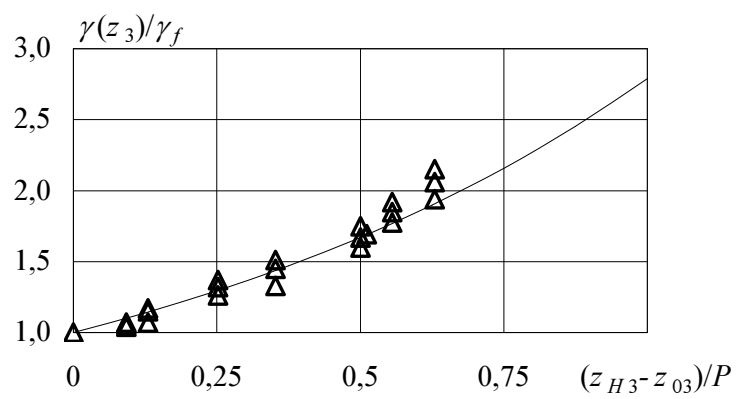

B.3 pav. Apskaičiuotų ir eksperimentiniu jungties įvijos paslankumų palyginimas ruožui $H_{3}$

Fig. B.3. Comparison of the calculated and experimental turn pair pliabilities for segment $H_{3}$ 
B.3 Paveiksle matyti, kad funkcijos (B.2) kreivè geriau aprašo eksperimentinius duomenis (taškus) svarbesnejje pirmojoje jungties ịvijos pusejje, kur vijų sukibimo gylis yra didesnis ir veržlès vija storesnè. Žinoma, kad realioje jungtyje antrajai jungties įvijos pusei tenka nedidelè apkrovos dalis, lyginant su apkrovomis, kurios tenka visu profiliu sukibusioms vijoms. Todèl jungties ivijos paslankumo reikšmių paklaidos, kurios atsiranda matematiškai aprašant paslankumą antrojoje „ploniausioje” jungties įvijos dalyje, daro labai nedidelę itaką apkrovų pasiskirstymo vijose skaičiavimo rezultatams. 


\section{C priedas. Lenkimo momento funkciju sankirtos}

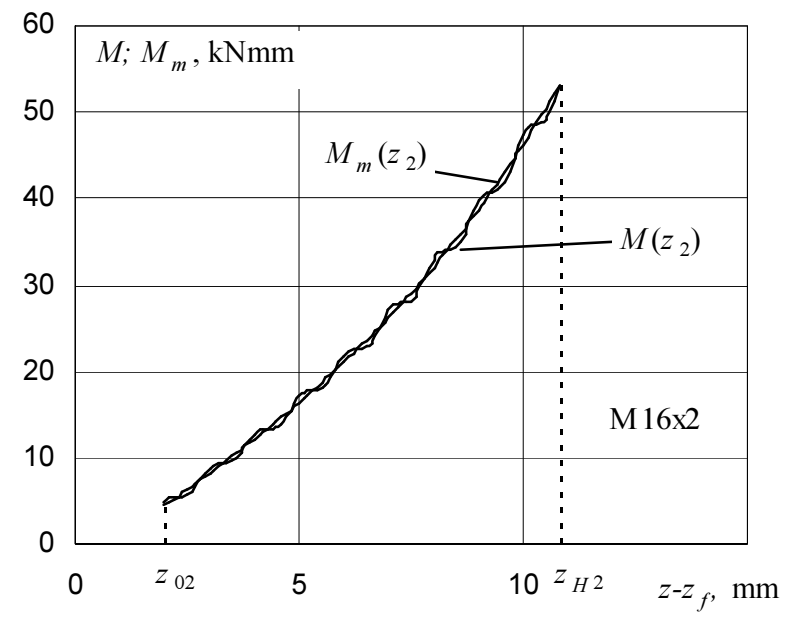

C.1 pav. Lenkimo momentų funkcijų sankirtos ruože $H_{2}$

Fig. C.1. Intersections of bending moment's functions in segment $\mathrm{H}_{2}$

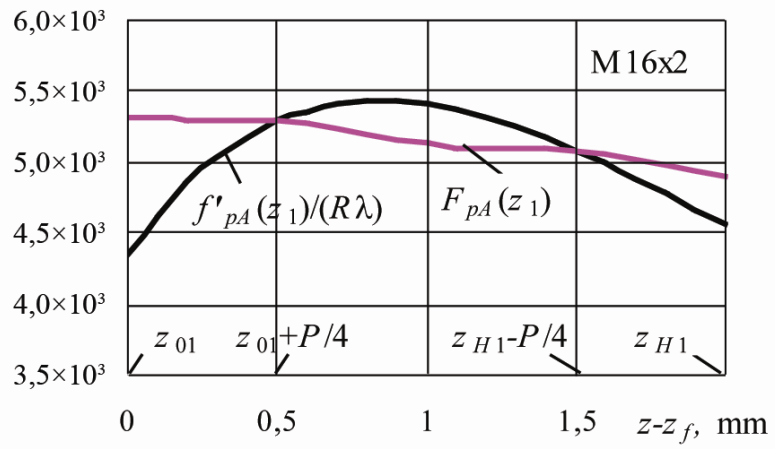

C.2 pav. Funkcijų $F_{p A}$ ir $f_{p A}^{\prime} /(R \lambda)$ sankirtos ruože $H_{1}$

Fig. C.2. Intersections of the functions $F_{p A}$ ir $f_{p A}^{\prime} /(R \lambda)$ in segment $H_{1}$ 


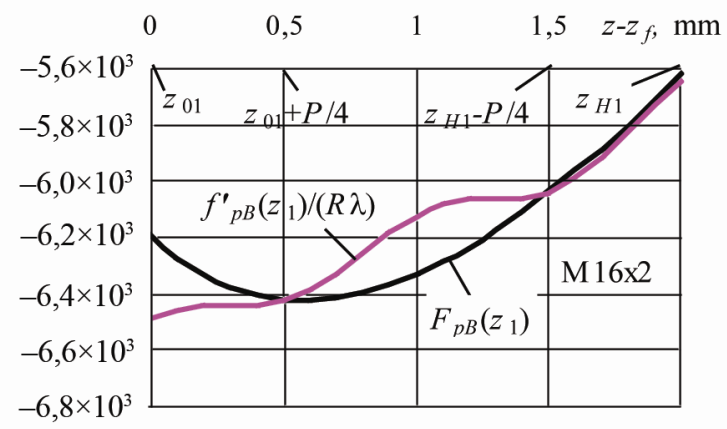

C.3 pav. Funkcijų $F_{p B}$ ir $f_{p B}^{\prime}(R \lambda)$ sankirtos ruože $H_{1}$

Fig. C.3. Intersections of the functions $F_{p B}$ ir $f_{p B}^{\prime} /(R \lambda)$ in segment $H_{1}$

$10,8 \quad 11,3 \quad 11,8 \quad 12,3 \quad z-z_{f}, \mathrm{~mm}$

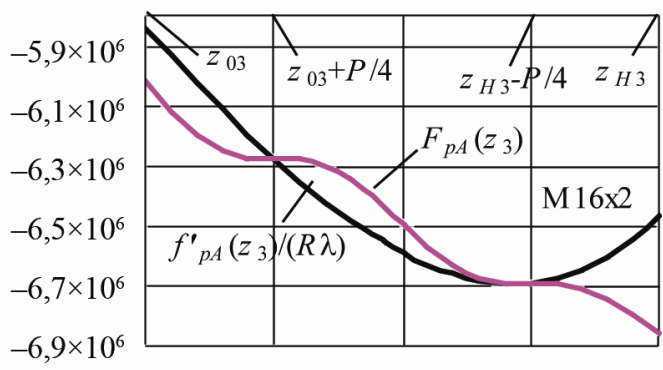

C.4 pav. Funkcijų $F_{p A}$ irf ${ }^{\prime}{ }_{p A} /(R \lambda)$ sankirtos ruože $H_{3}$

Fig. C.4. Intersections of the functions $F_{p A}$ irf ${ }_{p A}^{\prime} /(R \lambda)$ in segment $H_{3}$

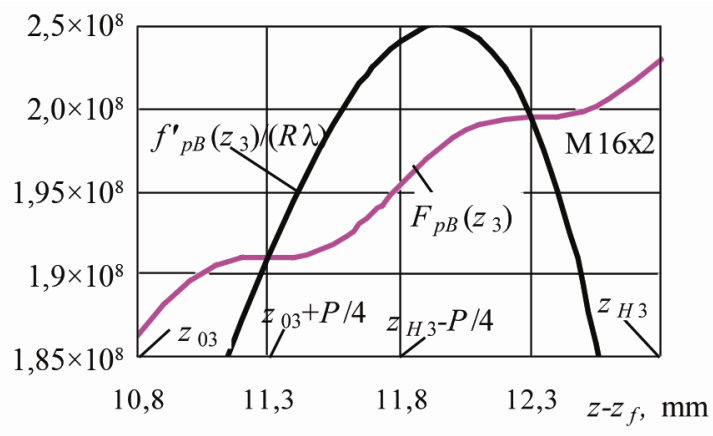

C.5 pav. Funkcijų $F_{p B} \operatorname{irf}{ }_{p B} /(R \lambda)$ sankirtos ruože $H_{3}$

Fig. C.5. Intersections of the functions $F_{p B}$ irf ${ }^{\prime}{ }_{p B} /(R \lambda)$ in segment $H_{3}$ 
Žilvinas JUCHNEVIČIUS

CIKLIŠKAI LENKIAMỤ SRIEGINIỤ JUNGČIŲ

DEFORMAVIMAS IR STIPRUMAS

Daktaro disertacija

Technologijos mokslai,

mechanikos inžinerija (09T)

DEFORMATION AND STRENGTH OF A CYCLICALLY BENT THREADED CONNECTION

Doctoral Dissertation

Technological Sciences,

Mechanical Engineering (09T)

201112 19. 10,75 sp. I. Tiražas 20 egz.

Vilniaus Gedimino technikos universiteto

leidykla "Technika“,

Saulètekio al. 11, 10223 Vilnius,

http://leidykla.vgtu.It

Spausdino UAB "Ciklonas"

J. Jasinskio g. 15, 01111 Vilnius 